THENORMALCHILDAND PRIMARY EDUCATION
CESELL:

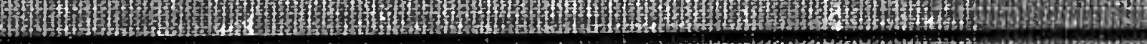

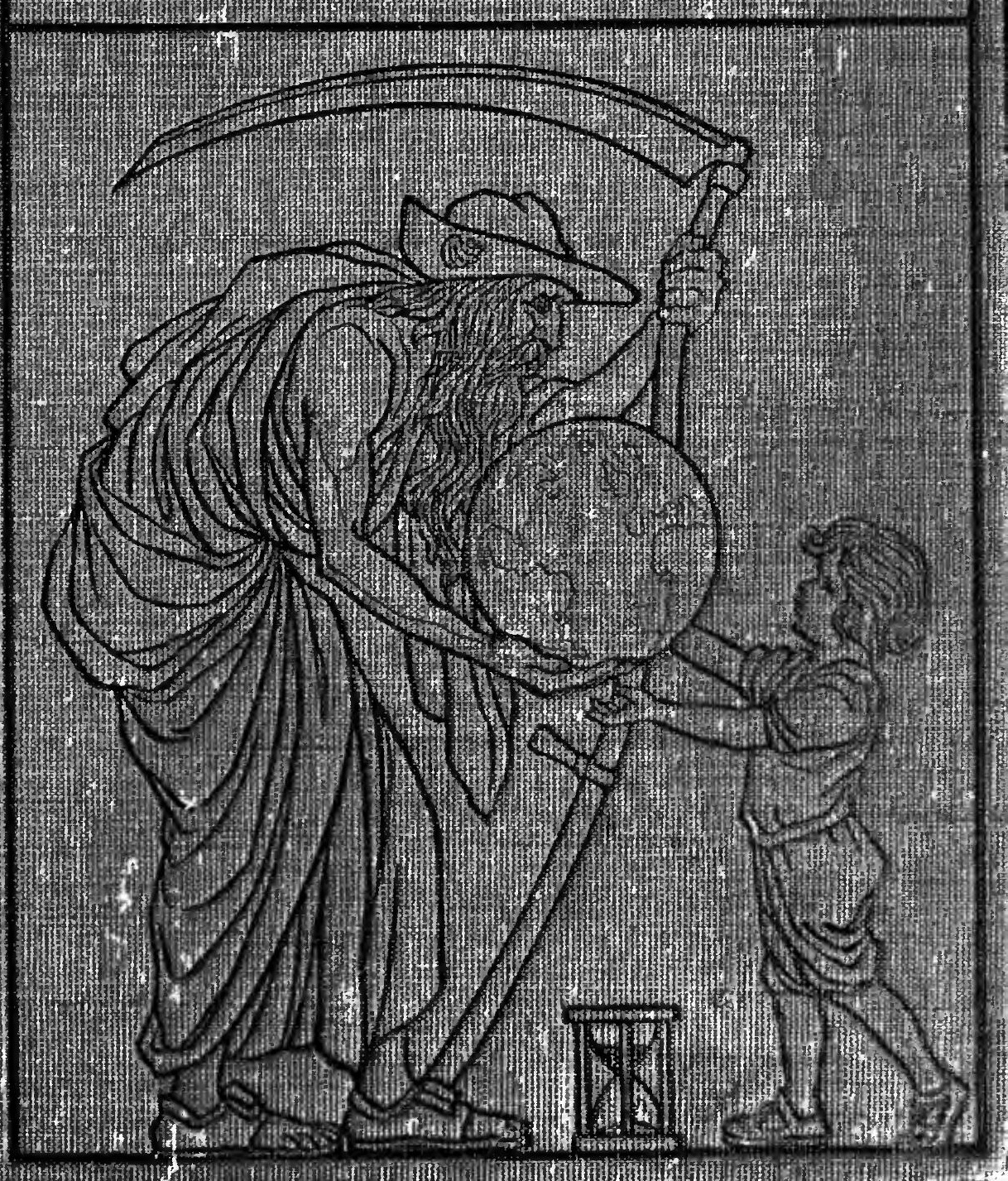


Preserited to the Mailman Library by Emily Pryor - September, 1936

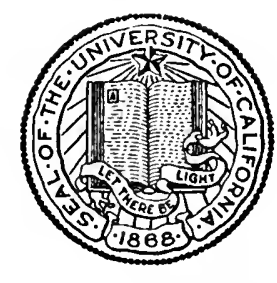

THE LIBRARY OF THE UNIVERSITY OF CALIFORNIA LOS ANGELES 

Emey on. Qrijoi
unvencur 1917 
Digitized by the Internet Archive in 2007 with funding from Microsoft Corporation 



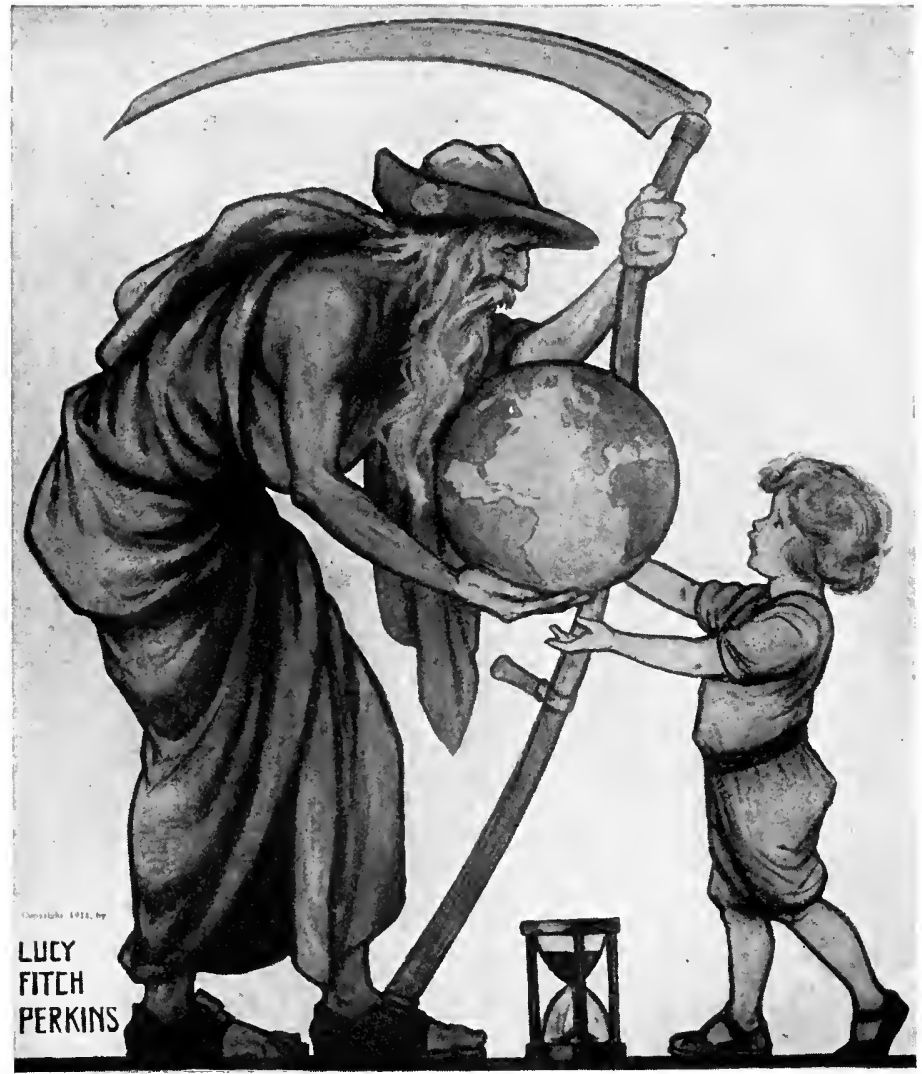

(C) Lucy Fitch Perkins, and used by nermission

Strexgthen the Little Haxds that aust carry on the World 


\section{PRIMARY EDUCATION}

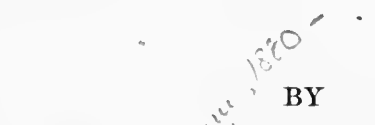

ARNOLD L. GESELL, Ph.D. (CLark)

DEPARTMEXT OF PSYCHOLOGY, LOS AXGELES STATE XORMAL NOW ASSISTAXT PROFESSOR OF EDUCATION, YALE UXIYERSITY

Axi

BEATRICE CHANDLER GESELL, Ed.B. (Chicago) FORMERLY PRIMARY TRAINIXG TEACHER LOS ANGELES STATE NORHAL 
COPYRIGHT, 1912, BY ARNOLD L. GESELL AND BEATRICE CHANDLER GFSELL

ALL RIGHTS RESERVED

916.10

Tbe gtbenaum Press

GINN AND COMPANY + PRO-

PRIETORS - BOSTON - U.S.A. 


\section{Ed. - Psych,}

Library

\section{$\angle B$ \\ 1507}

\section{PREFACE}

This book is the result chiefly of the authors contact with the eager minds of young women who were preparing to teach young children. These prospective teachers wished to have definite, workable suggestions in the arts of primary pedagogy. 'The future daily attack of the school program with its formiclable list of reading, writing, handwork, dramatics, etc., was to them a serious problem. We have tried to offer in the core of this book many straightforward, practical directions for the normal-school student and the teacher, but without the attitude of finality which puts an end to all self-help. We believe that one reason why there is not more spirit and originality in the lower elementary grades is that the teachers themselves too early suffer a subtle arrest in heart and mind elasticity.

The pedagogical chapters of Part Three aim to present constructive suggestions based in large measure on experience and experimentation, which included the mistakes and efforts of a host of earnest young teachers who had not yet been habituated to inflexible programs and methods. To these teachers we owe and feel a real debt of gratitude. Our indebtedness to The University of Chicago and to Clark University will be self-evident.

Part One is a brief historical introduction which sketches a summary of the history of science with reference to the problem of child life, and prepares the reader for the scientific chapters of Part 'Two. 'The latter represent a variety of material from the fields of biology and child psychology, 
selected and summarized to serve as a foundation and background for the pedagogical section. The chapters deal with large themes, not so much for the sake of exposition as with the hope that the schoolroom program and practice will be somewhat illuminated and dignified. The fundamental subjects of perception and instinct are fully treated, and the aim throughout is to develop the genetic point of view toward the child and education.

Part Four considers the child as a whole, with special reference to the larger aspects of physical and mental health or normality. Special attention is given to the normal mental hygiene of the child's personal power and growth.

What is a normal child? The prevailing standards consciously or unconsciously adopted in answer to this question are sadly slipshod, - even in the pedagogical world where high child standards ought to be religiously maintained. It is carelessly assumed that the normal child is the average child.

Teachers of defective children often confess that by a gradual process of instinctive toleration or adaptation they come to believe that even their inferior pupils are "all right," or at least "e pretty good." Such teachers resort to companionship with "normal" children in order to revive their fading standards of what is normal. The great mass of elementary school-teachers lapse into a similar undervaluation of what is truly normal; but they have no convenient place of reference where they can rectify their slumping standards.

We must go to science, to literature, to art, to revitalize our ideals of childhood. We ought to see more children in half-naked garb, as the Greeks did, - bare arms, legs, chests, - to give us a feeling for the beauty and nobility of the human form. We are becoming too satisfied with the collars 
and ribbons of our primary pupils, and not keeping alive our natural disapproval of the frail, unshapely bodies which clothes conceal. Likewise we are losing a sense of what is mentally normal.

The sciences of education have not, however, worked out a detailed psychophysical portrait of the normal child, and at present we have more adequate pictures of types of subnormality than we have of normality. A particular interest in the pronounced and pathological deviations from the medium has been to the detriment of the great medium mass of children, who, after all, are the most important, for the democratic reason that God made so many of them. There are over seventeen millions of pupils, the majority under ten years of age, enrolled in the public schools of our country. A small fraction are in special classes for the backward and defective. The rest are all "normal."

By reason of the vast amount and by reason of the peculiar potentiality of all this child life in the early grades, the primary teachers, who far out-number any other class of teachers, have a big part to play in the expanding movement for the conservation of national vitality. By bringing new health, gladness, and creativeness into the primary school, a large and precious measure of perishable elements in human material can be saved to the race. Part Four treats some possibilities in a new-old field of conservation.

The work in this fine field can be furthered, we believe, if those who have to do with children will develop and heroically maintain high standards of normal childhood in its various ages. This book may in some places do something to make more definite and elevated such standards of what is normal. We have not written for the technical clinician, but for the elementary school-teacher, and, 
of course, for other traditional guardians of children, as mothers, aunts, some fathers, supervisors, and child-study and reading circles.

It is preferable that the normal should approximate the ideal rather than the average. The higher and stronger the norm of normality the better for the race. 'The Greeks used the word "idea" to mean the model which existing objects imperfectly embody. Millions of the primary children in our " regular" grades imperfectly embody what is ideal, what is normal. We have not ventured far into the dangerous and uncertain problem of primary prodigies and precocity. According to certain new ideas of child culture, ordinary children by proper nursery pedagogy may be brought at primary age to high-school levels of intellectual advancement. Although there is nothing finally established as to the ultimate healthy limits of achievement in the primary child, we do believe that he is at present far below his possibilities, and think it regrettable that the primary schools continue to turn out such hordes of pupils subnormal in personal power. 'The primary child has many untouched reservoirs of interest and capacity. He is ripe for unguessed avenues of activity and attainment. Though we need not suddenly strive to make of him a prodigy, we can hold him more completely to what is soundly normal.

BEATRICE C. GESELL ARNOLD L. GESELL

Casa Verdugo, California 


\section{CONTENTS}

PART ONE. HISTORICAL INTRODLCTION

CHAPTER

PAGE

I. Humasitarianish AND tile Child . . . . . 3

II. The Sciextific Ixterpretation of Life . . . 8

III. Tile Sciextific Stuny of the Cinld. . . . . 17

PART TWO. THE GENETIC BACKGROUND

IV. The Biological Perspective. . . . . . . 29

V. The Phonthe Axcestry of the Chilb • • . 46

VI. Ixstixcé axd Ri:laxation. . . . . . . . 61

VII. The Haxd of the Race axd of the Child . 84

Vili. Touch and tie Appreciation of Things . . 106

PART THREE. THE PEDAGOGY OF THE PRIMARY SCHOOL

IX. Drawixg . . . . . . . . . . . . . . 125

X. Dramatic Expression . . . . . . . . . 144

XI. Phonics and Speech . . . . . . . . . . . 159

XII. Langlage . • . . . . . . . . . . . 172

XIII. HaNDWORK. . . . . . . . . . . . . 181

Niv. Literature . . . . . . . . . . . . 187

XV. Ribading . . . . . . . . . . . . 194

XVI. IIANDWRitixg . . . . . . . . . . . . 203

XVil. Natura Stem . . . . . . . . . . . 223

XVIII. BUSY-WORK . . . . . . . . . . . . 229

XIX. Outdoor Play . . . . . . . . . . . 237

XX. Morning Exercises . . . . . . . . . . 243

XXI. Discipline . . . . . . . . . . . 248 
PART FOUR. THE CONSERVATION OF CHILD LIFE CHAPTER

XXII. Pestalozzi axd Hone Edecation. . . . . 257 XXIII. A Healtiy Body . . . . . . . . . . 273 XXIV. A Healthy Mind . . . . . . . . . . . 289 XXV. The Saving Sexse of Humor . . . . . . . 296 XXVi. Formalism axi Cinld Persoxality . • . . 305 XXViI. Childhood the Foundatiox of Youtil . . . 310 BIBLIOGRAPHY • . . . . . . . . . . . . 315 APpendix. 'The Montessori Kindergarten . . . . 323 INDEX . . . . . . . . . . . . . 341 


\section{THE NORMAL CHILD AND PRIMARY EDUCATION}





\section{PART ONE}

\section{HISTORICAL INTRODUCTION}

\section{CHAP'TER I}

\section{HUMANITARIANISII AND TIIE CHILD}

The child has been called the last serf of civilization. Two sister influences have come to his emancipation, humanitarianism and science. A humanitarian attitude toward children would seem to be the most natural thing in the world. Even among the lower animals we find the instinct of parental sympathy, the root of all tenderness. But history shows in many pages how both instinct and reason have failed to develop an adequate regard for the child.

It was written in the sacred books of the Hebrews that the disobedient son should be stoned by the tribe with stones till he die. This severity belongs to the Old Testament régime. Some of the loftiest conceptions of childhood were to appear in the New Testament. Strangely enough, however, some of the most terrible misconceptions concerning childhood developed with the Christian Church. From St. Augustine to Jonathan Edwards, the doctrine of child depravity was proclaimed and practiced. It was enunciated and reënunciated by the early fathers, the Lutherans, the Council of the Reformation, the Calvinists, and the Puritans. For over a millennium this gloomy declaration, now so abhorrent to our humanity, was a mere truism. It must be 
interpreted with due tolerance by the present generation, but it cannot be brushed aside as a mere theological theory. Theory colors practice, and this idea that children, "by their carnal conception and nativity, came into this world steeped in sin and guilt, the heirs of hell," inevitably introduced many forms of insidipus cruelty into home and school. The puritanical spirit of abnormal sternness and repression, which interpreted simple childish mischievousness as the work of Satan, was directly descended from this honest belief in the utter depravity of human nature.

The best measure of the civilization of any people is the degree of thoughtful reverence paid to the child. The close of the eighteenth century, which brought forth ideas of liberty and emancipation on such a grand scale, is therefore well called the age of enlightenment. The roll call of that great epoch of Aufklärung included the names of Schiller, Goethe, Kant, Payne, Washington, Wilberforce, Jefferson, Fichte, Grimm, Wordsworth, Kosciusko, Bach, Voltaire, Herder, Schleiermacher, Rousseau, — a great medley, but proof that powerful liberalizing and humanizing forces were penetrating all departments of life. Elementary education in the fullness of time was to be transformed by this Aufklärung. The eternal worth of individuality was risin to a new recognition. "In a certain sense," says Natu" "all threads run together in the one idea of education for inmanity. At last man was anxious to understand the hotran in humanity, in order to develop the human in humanity."

One great name which must be added to the above roll call is that of Johann Heinrich Pestalozzi. This picturesque but powerful man was moved by the new enthusiasm for humanity. He believed that children, above all else, should be understood and loved; that in them lay the regeneration of the world. So he converted his home into a combined 
primary school and social settlement, and set the world a novel example of kindness for which it was becoming more and more ready.

In Pestalozzi's old age there came into existence a form of harshness to children which in many respects dwarfed that of any previous age, - the child labor of the Industrial Revolution. In England, the mighty land of looms, the trafficking in and enslavement of children became a veritable system, and the suffering and degeneration which fell upon thousands of defenseless creatures, toiling for fourteen and sixteen hours a day at the remorseless machines, are unspeakable. Southey exclaimed," Death in the brazen arms of a Carthaginian idol was mercy to the slow waste of life in the factories."

The liberation of children from industrial oppression is not yet complete. 'The resistance of the English mill owners, and even of parents and Parliament, _ including such statesmen as Brougham, Bright, Cobden, Russell, and Gladstone, - to the amelioration of these child laborers is a matter of history. The noble work of the Earl of Shaftesbury in the face of this resistance is also history. He compelled the nation not to work its children more than twelve hours a day; he rescued the little chimney sweep from the danger of fire and deatl; he covered all London witl ragged schools, and asylums for the homeless, and released a whole army of working boys and girls from factory, forge, and mine. Even thus, before dying, in 1885, he lamented: "I cannot bear to leave the world with all the misery in it."

England produced another great humanitarian in the person of Charles Dickens. His influence in creating a greater tenderness and respect for childhood in his own country, on the Continent, and in America, can hardly be overestimated. He was a contemporary of Lord Shaftesbury. These were 
the days when a man could mercilessly beat his wife, his beast, and his child, without a challenge; when orphans, idiots, and strays were herded into bleak workhouses, and when schools were " nurseries of vice," commonly presided over by "incapable pettifoggers or sorlid, brutal men to

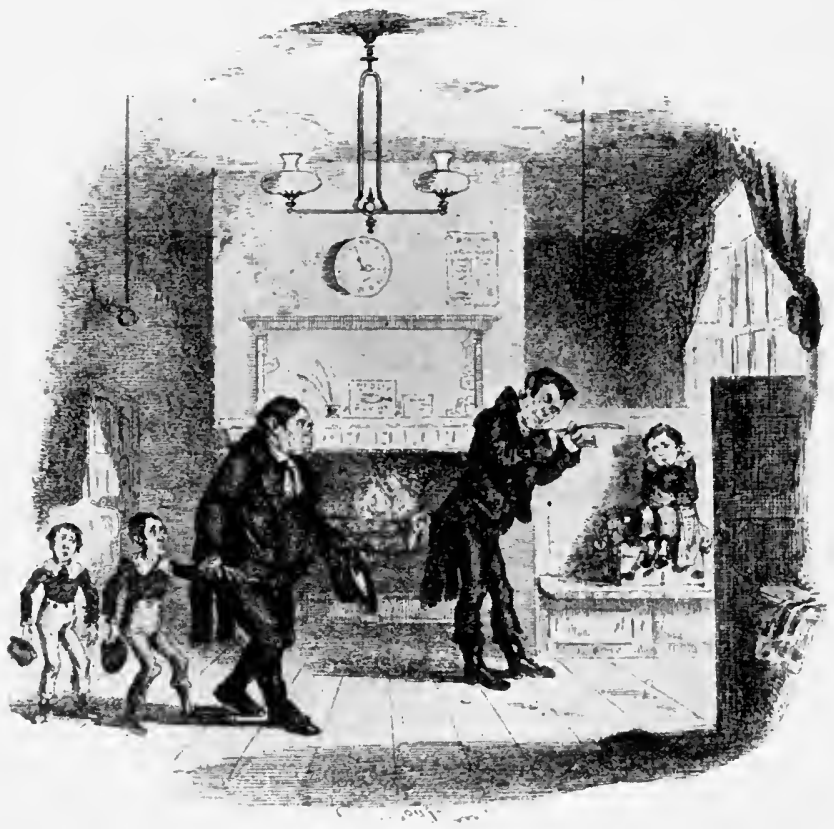

Fig. 1. SQleers

(From an old print)

whom few considerate persons would have intrusted a dog." Oliver 'Twist, Dotheboys Hall, Squeers, Nicholas Nickleby, Child Queller, and Choakunchild are names that bring a flood of associations true to actual conditions. "The pale and haggard faces, lank and bony figures, children with the countenances of old men," that stalk through 
Dickens's stories, were not merely the product of artistic imagination; nor were the schools "where every kindly sympathy and affection was blasted in its birth and every young and healthy feeling flogged and starved down." The real truth is that the doctrine of child depravity still lingered as a dominant Clristian ideal. Repression and corporal punishment were the rules. The greater mildness in methods of training and the very existence of many childwelfare organizations to-day are traceable to that eloquent champion of children's rights, — Charles Dickens.

At the centennial year of Dickens's birth it is interesting to recall such large expressions of the humanitarian attitude toward children as the Child Welfare Exhibit, held first at New York and recently, on a bigger scale, in Chicago. Hundreds of thousands of people in each eity visited this unique exposition, with its army of "explainer's" and its wealth of photographs, statistics, headline statements, and living demonstrations setting forth the conditions of city child life. Nothing could have been more significant of the greater solicitude for children, with which we associate the name of Dickens, than these remarkable and inspiring exhibits.

Humanitarianism is becoming part of the spirit of the race. One has but to glance through the directory of the charities of a large city to be convinced of this. While societies for the prevention of cruelty to children are still a necessity, deliberate and brutal forms of cruelty belong more to the past than to the present; but the unwitting cruelty of indifference and ignorance was perhaps never so extensive as right now. This, Science alone can dispel, by the enlightenment of the masses and by the cultivation of experts. 


\section{CHAPTER II}

\section{THE SCIENTIFIC INTERPRETATION OF LIFE}

The fuller appreciation of childhood to-day has by no means been due to the growth of the humanitarian spirit alone. The other great factor has been the development of modern science. The present splendid, growing body of scientific knowledge about life represents the most important achievement of the race.

With the end of the classic civilization, science, broadly speaking, came to a standstill and remained so for centuries. This is particularly true of the sciences concerned with the body and the mind of man, and therefore of the child. There was no scientific interpretation of life. All discussions on this vital central theme were carried on by the fruitless method of scholastic philosophy, and were never based on first-hand inquiry. Such inquiry into facts over which God had, it was said, purposely placed a mantle of mystery, was frowned upon as being unpious and prying curiosity. The merlicine, physiology, and psychology of the medieval period, therefore, were a mixture of error and fancy, except where the authorities whom the scholars were constantly quoting happened to be right.

Chief among these authorities were Galen and Aristotle, exponents of a former scientific culture. Even Aristotle, the greatest of the Greek intellects, was not always a safe guide. He thought that the soul pervaded the whole body, and had no idea of the nature and use of the nervous system, believing that the brain was a refrigerating apparatus to cool the 
passions that arose in the heart. Galen thought that the blood, by an oscillatory motion, reached the brain, where it was elaborated into animal spirits, which were conveyed by tubular nerves throughout the body to impart motion, etc. This belief in humors, spirits, and sympathies persisted as a source of confusion down into the nineteenth century. Burton, in his quaint work "The Anatomy of Melancholy," calls spirit "a most subtle vapor which is expressed from the blood, and the instrument of the soul to perform all his actions." A few other sample views follow: The optic nerve is a tube through which visual spirits pass, carrying ideas from the air and idola from objects to the brain; the liver is the seat of love, and the spleen of wit; the brain increases and decreases with the phases of the moon ; sensation and motion are in the first ventricle, imagination and cogitation in the third ventricle.

Medicine, which like pedagogy depends upon a solid foundation of science, was discouraged. Drugs and sanitation were actually opposed. Because sickness was thought to be due to evil spirits, healing was performed by miracles, fetishes, charms, relics, amulets, potions, exorcisms, royal touch, and by tortura insomniae. Hundreds of thousands of men, women, and children were tortured for being the instruments of Satan. We are now certain that they were not under the influence of witches or Satanic imps, but simply suffering from diseases of the nervous system. But with a systematized resistance to the investigation of the nervous system, Nature snugly concealed her facts and laws from the eyes of sinful man. The most elementary facts about the child as a psychophysical mechanism simply were not understood or were misunderstood. Theological conceptions such as the doctrine of child depravity took the place of scientific interpretation. Man did not even know how many 
ribs he had, because theological interpretation was preferred to the testimony of eye and hand.

With the age of geographical discovery was ushered in a spirit of scientific discovery. Both partake of a similar impulse, - man's adventurous daring to penetrate the unknown.

One of the greatest of the pioneers of discovery was the impetuous, forceful Belgian, Vesalius, the father of modern anatomy. In the face of conservatism, prejudice, and actual persecution, he abandoned the venerable charts of Galen and went straight to the facts of nature.

The original of the accompanying portrait of Vesalius, now in Comell University, is eloquently described by Andrew D. White in his "History of the Warfare of Science with Theology": "By the magic of Hamann's pencil Vesalius again stands on earth, and we look once more into his cell. Its windows and doors, bolted and barred within, betoken the storm of bigotry which rages without; the crucifix, toward which he turns his eyes, symbolizes the spirit in which he labors; the corpse of the plague stricken beneath his hand ceases to be repulsive; his very soul seems to send forth rays from the canvas, which strengthen us for the good fight in this age."

Dissection of the body had for centuries been frowned upon as impious, but Vesalius " haunted gibbets and charnel houses" so that he might secure material for his classic work "De corporis humani fabrica." This great, "sincere book," beautifully illustrated with accurate drawings, laid the foundation of modern biological science. Locy says, "It is more than a landmark in the progress of science; it created an epoch." In the spirit of modern science he performed experiments on living structures to determine their function. This method of experimental observation, which Harvey 


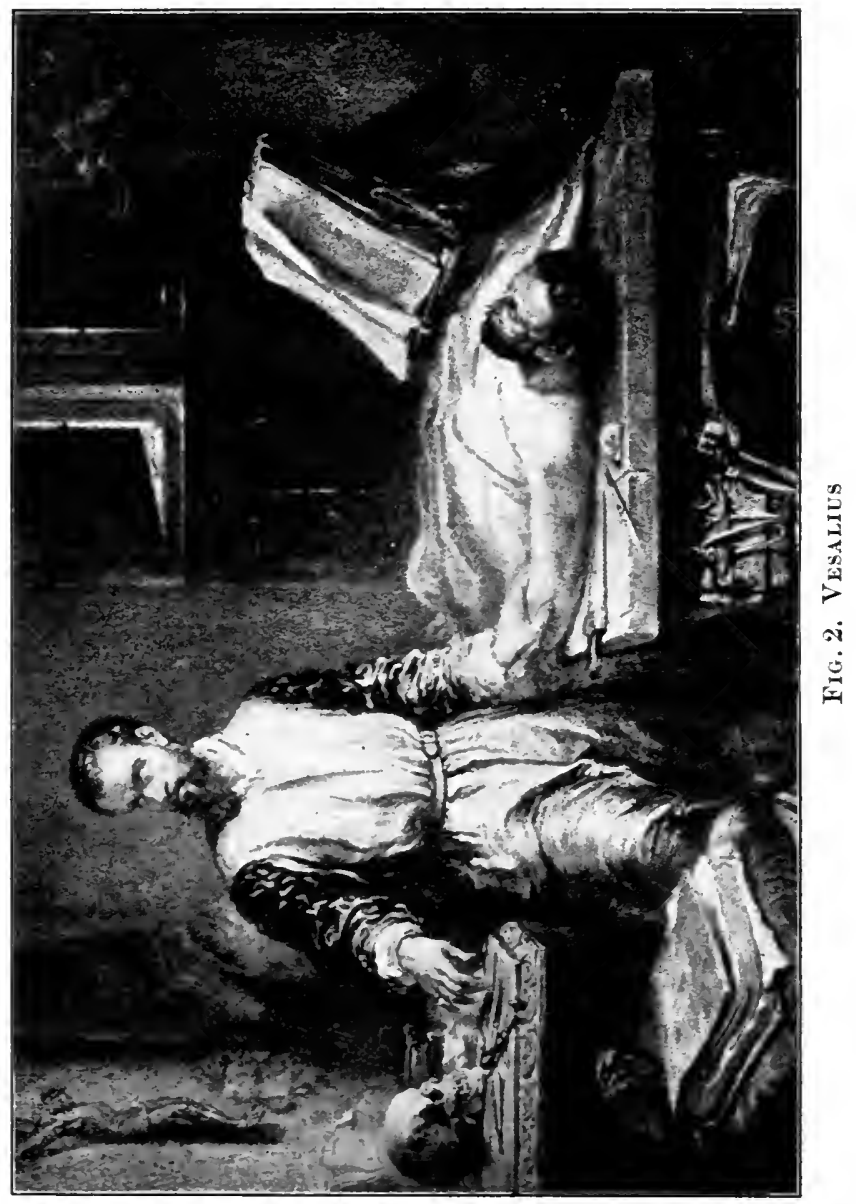


introduced in the study of the living body, has never ceased to this day. It has been most fruitful in deepening our insight into life. With Harvey it resulted in that most fundamental truth, the circulation of the blood.

A century after Harvey, Albrecht Haller, the learned Swiss, made his observations which overthrew the old doctrine of animal spirits. He established the independent irritability of muscle and nerve tissue, and thus paved the way for a scientific interpretation of reflex action. He gathered the chief facts and theories of his time into a volume of vast learning, and may be considered with Harvey one of the founders of modern physiology.

The nervous system soon came to be recognized as the supreme organ of the body, and conceptions in respect to it took shape. Sir Charles Bell, in 1811, distinguished the motor and sensory branches of the spinal nerves, which led to the modern theory of reflex action. This theory explains reflexes on a mechanical basis, tracing an impulse over a physical highway to its culmination, without calling in the assistance of a semitelepathic sympathy. The old notion which made the brain a gland, a distillery for subtle vapors, similarly had to give way for the illuminating facts about cerebral localization. In 1860 the great French surgeon Broca discovered the particular area in the brain which controls articulate speech. This brilliant discovery was followed by others which have to a marvelous degree explained the nature and functions of the human cerebral cortex.

There are two branches to the study of anatomy. One, gross anatomy, investigates the larger conformations and relationships of the structures; the other is minute anatomy. When the compound microscope was invented, at the close of the sixteenth century, the observation of nature was raised to a higher power. The early microscopes were 
crude and clumsy affairs compared with the beautiful instruments of to-day, but the revelations which they brought forth fascinated the pioneer microscopists so that they sacrificed their eyes and gave their lives to an exploration of the minute. Grew of England studied the fine structure of plants and regetables; Malpighi of Italy wrote on glands and capillaries and the anatomy of the silkworm; Swammerdam produced a marvelous treatise on the honeybee; Leeuwenhoek distinguished himself by his discovery of microscopic animal forms, which he called animalcula.

Locy quotes a paragraph which gives us an interesting glimpse into the work of Swammerdam: "His daily labors began at six in the morning, when the sun afforded him light enough to enable him to survey such minute objects, and from that time until twelve he continued without interruption, all the while exposed in the open air to the scorching heat of the sun, bareheaded, for fear of interrupting the light, and his head in a manner dissolving into sweat under the irresistible ardor of that powerful luminary." At night he was almost as constantly engaged in recording his observations by drawings and suitable explanations.

The protozoa, ever since their discovery by Leeuwenhoek, have been studied with great energy and ingenuity. In them the phenomena of life and behavior are reduced to elementary terms, which offer much suggestion for physiology and psychology. Especially notable in this field are the labors of Verworn, O. Fr. Müller, Ehrenberg, Metch nikoff, Jennings, and Loeb.

Bacteria are microörganisms allied to the protozoa. They belong to the world of the infinitely small, and could not be studied with effect until the perfection of the compound microscope in the nineteenth century. The germ theory of disease, which had been suggested a generation 
earlier, was experimentally proved by Pasteur and Koch in 1877. Bacteriology is now an important department of biology, and the brilliant researches in this field have contributed their valuable share to the protection and comprehension of child life in health and disease.

No science has contributed quite so much to an understanding of the mechanics of behavior as has the science of histology. This science carries anatomical analysis to its minutest elements, inquiring into the organization of the tissues themselves. 'The historian tells us that the name of the brilliant young Frenchman Bichat must be ranked with that of Vesalius, because he initiated these profound, far-reaching structural investigations. The modern cell theory, which was established by Schwann, Schleiden, and a long line of other laborers, was the first great generalization resulting from histological study. This theory, which we so freely imbibe and which nowadays is taught to primary children, was not announced until 1838. Twentythree years later Schultze established that other epochmaking generalization, the doctrine of protoplasm. 'These two grand conceptions are among the most far-reaching achievements of modern science. They unify and identify in a fundamental way the structures of plants and of animals, reducing them to elementary globules of protoplasm, living cells. Protoplasm is the physical basis of life, which links the child with all organisms, even the lowest. Biology is the science of life. It is no wonder that Max Schuitze should sometimes be called the father of modern biology.

The histologists the world over are still busy describing, drawing, and photographing the myriad cells, in health and disease, which make up our bodies and those of plants and animals. They have even estimated the total number of cells in the human body. These cells are not the same 
in size, shape, or importance. If we arrange them in a hierarchy, the nerve cells - some eleven billion in number - must be considered the most aristocratic, for it is they which initiate and control all our behavior, in its parts and in its organized wholes, from the winking of an eye to the writing of a speech, - our conscious and our unconscious behavior, from the peristalsis of our intestines to the framing of a philosophical system. It is these nerve cells which we must understand if we would know the laws behind that most subtle and delicate piece of machinery, the child. The science of neurology, which has for its subject the nerve cells, has furnished invaluable interpretations for psychology and education.

It would be incorrect to think that neurological investigation depends chiefly upon the patient use of the microscope. Nature does not so readily yield her secrets. In the case of nerve tissue the high-power microscope alone often only magnifies her refusal to yield. It took the united cunning of a generation of students, the world over, to devise a strategy which compelled nature to reveal the internal architecture of the nervous system. This strategy is represented in the elaborate technical methods of preparing tissue for study, contained in the huge manuals of the art of microscopy. Before tissue is ready for examination it must be fixed in alcohol, hardened and preserved, embedded in paraffin, cut into delicate sections by the microtome, stained by various dyes, and mounted between glass. All the great biological and medical laboratories now contain hundreds of these microscopic preparations, specimens from the deepest layers yet penetrated in nature's fathomless mine.

Nowhere are the persistence and the patience, the cooperative and cosmopolitan spirit of modern science more 
beautifully shown than in the field of neurology, which numbers among its great men Deiters, His, Gerlach, and Nissl from Germany; Purkinje, a Bohemian; Golgi, an Italian ; Forel, a Swiss; Nansen, a Norwegian; and Barker, Donaldson, and Hodge, Americans. To this list must be added the euphonious name of Ramon y Cajal, a Spaniard, who ranks most renowned among the army of laborers who have enlightened us in regard to that most important factor in the life of the growing child, — his nervous system. 


\section{CHAPTER III}

\section{THE SCIENTIFIC STUDY OF THE CHILD}

After all has been said, the most profoundly revolutionary and productive event in the history of biological thought was the publication, in 1859, of Darwin's "Origin of Species." Everything in nature has a pedigree, a history. An organism is really not understood even when anatomy, physiology, and histology combine to explain its structure and mechanism in minute detail. There always remains the great historical question of origin and development. This was Darwin's problem, and to its solution he consecrated his genius. As early as 1835 , on his voyage around the world as naturalist on his Majesty's ship the Beagle, the problem occurred to him. In his famous letter to the botanist Hooker he says: "I was so struck with the distribution of the Galapagos organisms and with the character of the American fossil mammifers that I determined to collect blindly every sort of fact which would bear in any way on what are species. I have read heaps of agricultural and horticultural books and have never ceased collecting facts."

The origin and development of species is a venerable problem. Aristotle spoke of a principle of perfection running through the universe. The medieval scholars naturally accepted the Hebrew account of the genesis of all things and the preservation of species in Noah's ark. In fact, the belief in the immutability and special creation of species persisted into the nineteenth century. Limnæus, the great 
naturalist whose system of nomenclature did so much to bring order and classification into the accumulating knowledge about plants and animals, believed all species were created in the beginning. He was acquainted with only four thousand species of animals, whereas it is now known that the species, extinct and living, must easily number a million. As the fossil remains of extinct creatures came to be better known, the idea of the fixity of species became more and more untenable. Buffon, Erasmus Darwin, and Goethe all doubted such fixity. Cuvier, to defend the prevailing concept, presented the theory of cataclysms, which asserted that there were successive eras of destruction and creation, and fossils were the remnants of these ancient cataclysms. Lamarck held that these fossils represented the ancestors of living forms. He worked out a comprehensive theory of descent and mutability of species which entitles him to be called the father of evolutionary thought; but he was neither happy nor fruitful in suggesting the way in which species originate and are transformed. Charles Darwin, after twenty-five years of quiet, patient study, presented an explanation of the way in his epoch-making book.

His explanation was the principle of natural selection, which Romanes calls the most important idea ever conceived by man. This principle, like a telescope, freed man from the narrow horizon of the present and the recent, and allowed him to glimpse down the deep perspective of the geologic past. It gave him some conception of how all the manifold earthly flora and fauna came to be what they are. Not only in the special fields of zoölogy and botany did it extend the vision, but in every department of thought the interpretations of men were given a new range and depth. 


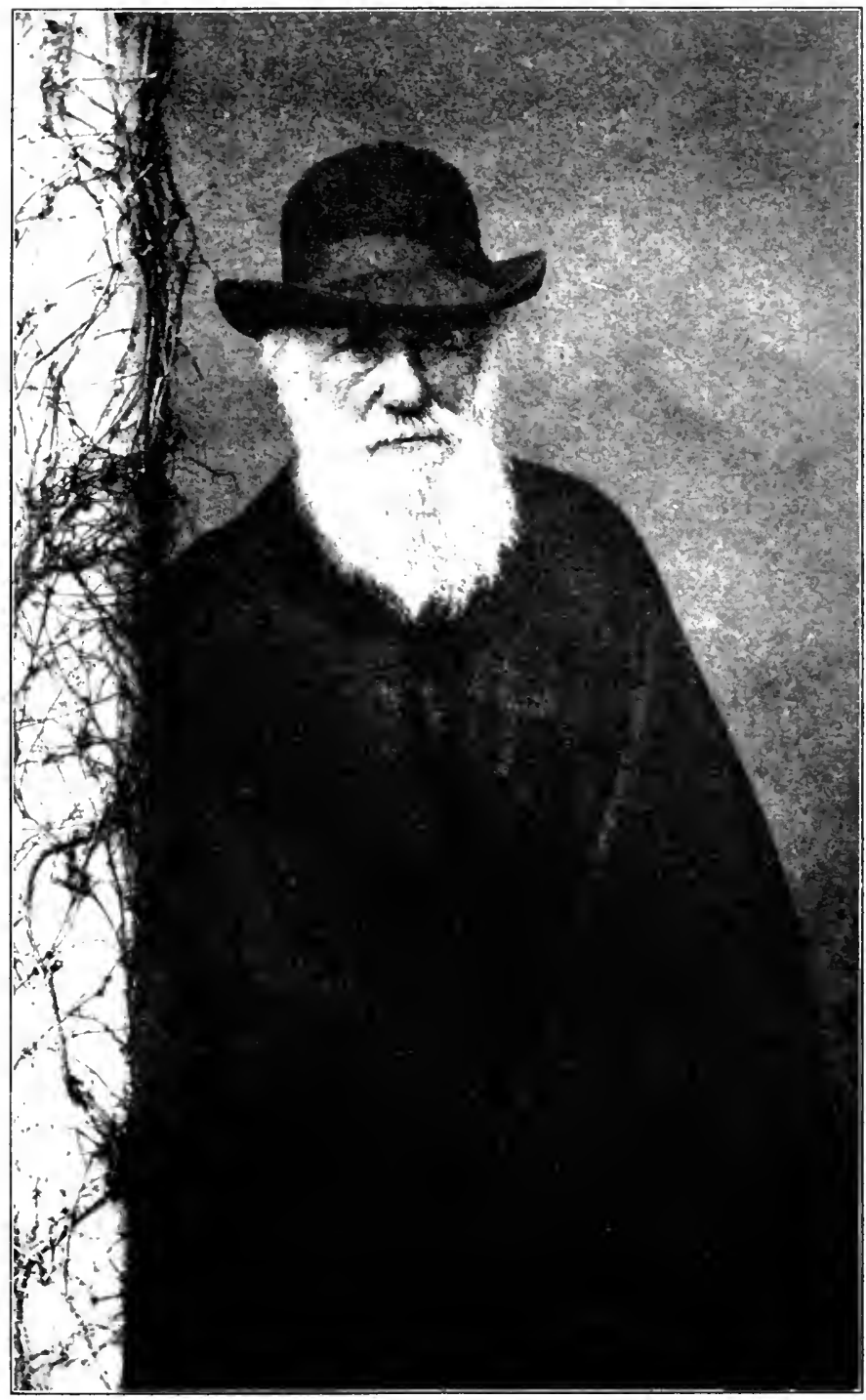

(C) D. Appleton and Company

Fig. 8. Chatre- Dakwiy

(From "More Ixtters of (harles Darwin") 
Thus sociology, anthropology, politics, and even theology reshaped their subject matter along the new genetic lines. Embryology became less purely anatomical - became almost "romantically historical" under the new Darwinian influence. Through the labor of Fritz Müller, Balfour, Marshall, and Haeckel, one of the most wonderful of all scientific generalizations was worked out, - the theory of recapitulation, which holds that animals, in their individual unfoldment, to a considerable degree recapitulate the phases of their phyletic or racial development.

So extensively was the intelligence of the age affected that the nineteenth century has even been called Darwin's century. "Whatever the verdict of posterity," - quoting from Huxley, the ardent champion of Darwinism, - " the broad fact remains that since the publication, and by reason of the publication, of the 'Origin of Species,' the fundamental concepts and aims of the students of living nature have been completely changed."

The child is a part of living nature. The greatest modern student of the child is G. Stanley Hall. When the history of science is seriously recorded, his name will be linked with that of Charles Darwin. Both are large-visioned interpreters of nature, combining scientific methods with a philosophic temper. Darwin applied his genius to the great genetic problems of biology; Hall is the Darwin of psychology. Both have gleaned the fields of paleontology, geology, anthropology, botany, and zoölogy, to set forth illuminating interpretations concerning the development and expression of life. In many fields their studies overlap. Indeed, the psychology of Hall is biological; he has brought these two sciences into intimate and fruitful union. Darwin could limit himself, rather strictly, to measurable, verifiable data, in his studies of the plant and animal kingdom; Hall's 
labors lie in the much less tangible kingdom of soul, and in this difficult, submerged field he has manifested intuition and suggestiveness characteristic of genius. He has collected his data from every possible source, - from biography, and great quantities of confessions and questionnaire returns; from prisons, insane wards, medicine, superstition, myths, folklore, - all for the purpose of restoring to our appreciation the extinct phases of the life of the soul. For he believes that our present consciousness is but a species, a stage in evolution; that its history began with the origin of organic life, if indeed not earlier, and that it inherits as instincts, latencies, rudiments, recapitulatory nascencies, or unconscious impulses, the prehuman features of its development.

G. Stanley Hall is at once the foremost leader of genetic psychology and of the child-study movement. No one has so clearly and consistently held that the child is a worthy center of unity for a new synthesis of all the knowledge bearing on physical and mental development. He has not strood aloof from the popular and practical phases of such a movement, but has encouraged a harmony of psychology and pedagogy, of science and all sociological endeavor which concerns the child.

Such a specific and focalized interest in the child is of very recent date. In 1775 Pestalozzi began his quaint diary of a father, which contains random observations and a few naïve experiments on his son Jacobli. 'The entries are often emotional and prayerful, and yet they contain a vein of empiricism which links them to the later systematic studies of children. In 1787 'Tiedemann wrote his "Observations on the Development of the Minds of Children."

In 1826 appeared Froebel's wonderful book " The Education of Man." Miss Shinn, herself the author of an important 
work on the mental development of the child, has half humorously suggested that Froebel's works are like the Koran, and that our subsequent child study is like the Alexandrian Library: "If child study agrees with Froebel, it is of no use, burn it; if it does not, it deserves only to be burned." Froebel undoubtedly ranks among the deepest interpreters of childhood. He appreciated the value of play, and his writings are pervaded with the concepts of growth and development. But these concepts were derived from a half mystical, philosophical view; they are prophetic and intuitive rather than biological. Darwinism had not yet come. Froebel's theories present a curious admixture of the logical and the genetic points of view, and in the light of present knowledge they need correction at many places. Much of the meaning that lies only vaguely hidden in Froebel has been made explicit by recent child study, so it would not be wise to burn the latter.

It is very significant that Darwin should have written a diary on the development of his infant son. This diary consists of scientific observations strikingly different from Pestalozzi's pious notes. It is the natural forerunner of the modern studies of children which began with Preyer in Germany and with G. Stanley Hall in America.

The "Study of the Contents of Children's Minds on entering School," by Hall, is the first landmark in the child study of this country. This interesting census revealed a most wonderful amount of error and ignorance in the primary child's information, and showed the practical usefulness as well as scientific interest of inquiry into his characteristics.

We can only make a compressed summary of the subsequent development of child study. G. Stanley Hall, with an enthusiastic group of coworkers and students at Clark 
University, has been the chief leader of this development. $\mathrm{He}$ founded the Pedagogical Seminary and the American Journal of Psychology for the publication of child-study investigations. His monumental work "Adolescence" ranks as the most important contribution to child-study literature. This work embodies an incredible amount of study in the varied fields of physiology, anthropology, sociology, sex, crime, religion, and education, and furnishes new insight into a most baffling and vital problem. Hall has just completed an equally monumental work entitled "Educational Problems." Besides a large number of minor books and the studies in the Psychological Review and other journals, J. Mark Baldwin's two volumes entitled "Mental Development in the Child and the Race" may be mentioned as one of the most ambitious efforts to generalize in the new field of genetic psychology.

Child study as an organized movement took shape at the International Congress of Education, at the World's Columbian Exposition, with the founding of a national society for the study of children. In the same year the British Association for Child Study, which has ever since had a prosperous career, was founded. Organizations sprang up in many states all over the Union; especially active was the society in Illinois. The activity and enthusiasm of these many organizations, though destined to wane after the first outburst, were proof that the new theories about children were gaining footing. These societies have done great propagandic and educative service, and the unnumbered child-study circles, in large cities and small, to this day are assisting in bringing to a wider realization, both in thought and in practice, modern ideas of education.

One of the most important of the organizations which have sprung up in connection with the child-study movement is 
the National Playground Association. The playground movement illustrates the unique character and spirit of the child-study movement as a whole, - a focalization of thought upon the nature and needs of the child; a union in understanding and helpfulness of experts, laymen, academic investigators, and practical workers. Our present appreciation of play has largely had its source in the biological studies of instincts. These studies received their main impetus from Darwin's suggestive labors. Lloyd Morgan's investigations of animal instincts, Groos's two important books on the "Play of Animals" and the "Play of Man," Johnson's and Gulick's studies of play interests, and Hall's writings furnished the scientific sanction for the renaissance of play. Educators, social workers, and citizens are uniting to put these scientific findings to use. Similar things are happening in every department of education and social effort, - in school hygiene, in the revival of the dance, in juvenile crime, in children's amusements, etc.

Child study primarily, however, is a science, or an inductive synthesis of all the sciences dealing in any way with the nature of childhood. Of fundamental importance are the special and accurate investigations of the laboratory. The first laboratory in experimental psychology was established by Wilhelm Wundt in 1878. Since then such laboratories have sprung up the civilized world over, and systematic researches on children, their processes of learning, judging, remembering, etc., have fumished important contributions to child study. 'Two notable works have appeared in Germany on the subject of experimental pedagogy, - one by Wilhelm Lay, the other by Meumann, a student of Wundt. Lay has also established a magazine entitled Die experimentelle Pädagogik. This new field represents an application of the mathematical and instrumental methods 
of experimental psychology to the problems of pedagogy. In Antwerp the municipality has founded a pedagogical laboratory.

The new courses appearing in our universities and the character of the recently founded Journal of Educational Psychology indicate the growth of experimental pedagogy in America. Dr. H. H. Goddard is conducting a research laboratory in connection with the Vineland, New Jersey, School for the Feeble-minded, which will further the solution of Binet's problem of devising satisfactory tests for the mental diagnosis of defective and dull children, and will throw light on their education. Similar research stations have been established in connection with institutions for the feeble-minded at Lincoln, Illinois, and Faribault, Minnesota.

Through the inspiration and leadership of Colonel Francis Parker and Dr. John Dewey, the Elementary School of The University of Chicago has been a semi-experimental center for the development of original pedagogical ideas which have leavened our public-school system. Columbia University with its Teachers College, and the Horace Mann and Speyer schools, have produced many studies in the field of education. Especially notable is Professor Thorndike's application of refined statistical methods to the measurement of mental capacity and development. Dr. Lightner Witmer, in Philadelphia, has started a unique work in the study of backward children. He conducts a psychological clinic, and issues a monthly journal devoted especially to the study and treatment of retardation and deviation. Signifi. cant also is the recent appearance of Dr. G. M. Whipple's "Manual of Mental and Physical Tests," - "a book of directions compiled with special reference to the experimental study of school children in the laboratory or classroom." 
Some day, probably, laboratories of child study and educational hygiene will be a regular feature of every large public-school system in America. Indeed, the school board of Chicago has, since 1899 , maintained an official Department of Child Study and Pedagogic Investigation, under the direction of Drs. Christopher, Smedley, Bruner, and Macmillan. New York City and the Russell Sage Foundation have each created a Department of Child Hygiene. Medical inspection of schools has extended into hundreds of American cities.

All these facts declare the trend toward a more universal diagnosis of the health and educational needs of individual children. This is the logical outcome of the scientific study of the child. It is the natural outcome of the scientific interpretation of life. Such interpretation reveals the laws of life and develops a new conscience toward these laws. The end-result will be a revolution of the work of the schools, because the traditions and inherited organization of the schools contain no true conscience as to health.

The traditional mission of the schools has been the transmission of culture, the imparting of skill and information. The new biological temper, which is the product of modern science, exalts hygiene and makes health the central solicitude in all the work of education. How recent is this new attitude of the school is brought home to us by Dr. Ayres: "Eleven years ago the school superintendents of America, assembled in convention in Chicago, discussed the problems then foremost in educational thought and action. Diligent search through the printed report of that meeting disclosed no single mention of child health, no word about school hygiene, no address devoted to the conservation or development of the physical vigor of youth. At that time eight cities in America had systems of medical inspection in their 
public schools. To-day the number of such systems is over four hundred. This development is without parallel in the history of education."

The new changes in education have been directed chiefly toward the care of backward, defective, and delinquent children, but incidentally the normal child is being benefited in untold ways. And he will reap the large benefit in the future. The new biological temper in education is also normalizing and training our humanitarianism. 'Through science, humanitarianism is losing some of its sentimental tears and romantic miscarriages, and changing into a more robust attitude of justice and protection, - protection of the health and vigor of normal children. Historically, Child Hygiene, yesterday only a phrase; but already becoming a program for action, is a phase or an outgrowth of the scientific study of the child.

The child-study movement has grown to be so complex that a notable effort was recently made to bring its many phases into closer relationship. In July, 1909, there was held at Clark University a series of conferences which, in the light of the history we have sketched from prescientific times to the present, takes on considerable interest and significance. At these conferences were gathered leading representatives of the following interests: day nurseries, kindergartens, child psychology, medical education of defectives and subnormal children, open-air schools, tubereulosis in children, eugenic movements, psychological clinies, school nurses and physicians, settlement work for children, boys' clubs, Sunday school, industrial training, child labor, story-telling league, children's theater, playground movement, children's libraries, dancing and music, the juvenile court. It was a general child-welfare congress. A children's institute was founded, which will be a repository for 
information and a disseminating center of service, correlating the scientific studies of children with practical methods for advancing their physical, mental, and moral well-being. Experts and practical laymen, psychologists and social workers, were all present to learn from each other and to help each other. They gathered with a focal interest in the child. It was a blending of the two great forces which have been accumulating volume down the centuries and are now coming consciously to the rescue of the child, Humanitarianism and Science. 


\section{PART TWO \\ THE GENETIC BACKGROUND}

\section{CHAPTER IV}

\section{THE BIOLOGICAL PERSPECTIVE}

The child is situated between two vistas, one of which reaches into the remote past, the other into the pregnant future. Sometimes teachers are not conscious of either vista, and this is shortness of sight. It takes a combined seer and prophet to see clearly in both directions, and the teacher should be as much of each as possible. The reason why so much of the school's activity is petty, or seems petty, is because the teachers are themselves petty-visioned. The present in the individual, in the race, and in society is but a stage of evolution, which can be understood only in terms of the past. The child is not a static thing which mere logic, however sharp, can by analysis dissect and thus explain. Childhood is all recapitulation, nascency, and growth. The child has a pedigree, both human and biological, and to appreciate him we must think historically.

This means that we must unclamp the chronological imagination and give it freedom to roam back even beyond the days of Moses and the Pharaohs. Our forefathers were very parsimonious with their chronology, and a Cambridge University scholar in the seventeenth century, after an exhaustive study, specifically limited the imagination to 
4004 B.c., October 23, 9 A.M. (the pedagogue is apt to think, perhaps, that everything worth while begins at about 9 A.M.). But this is the age of evolution, when a millennium in nature's history is considered but the winking of an eye.

Haeckel, by an ingenious condensation, makes the vastness of geological epochs comprehensible. Allowing one hundred million years for the age of life on our globe, and calling this immense period a solar day, the span of time since Moses becomes less than five seconds. G. Stanley Hall, in a recent article, has argued that it is " more scientific, surer, and psychologically better to assume and to think in vast units of time, not merely to indulge the momentum of evolutionary thought but as an aid to clearer insight and to larger views of the universe." "The visible universe is one of countless forms which its substance and energy have taken on, and the oldest objects in any corner of it are novelties to a mind vast and ancient enough to grasp the larger history of its eternal flux."

In the immeasurable beginning, when the earth was without form and void, there may have been a time when the very chemical elements, some eighty in number, which are at the basis of the material universe, were nonexistent, when they, like man, were but possibilities. The transformations of radium suggest how in the rons the distinctive molecules may have been formed by variation in number and arrangement of primitive electrons. G. Stanley Hall, after reviewing the new conceptions of matter and energy, and marshaling many impressive examples of the lifelike qualities of glass, iron, mereury, colloids, crystals, and other inanimate substances, concludes that "the world in its inorganic phases is perhaps more vividly active than life itself. The secrets of the origin of the soul are now more 
clearly seen to be bound up, if not identical with, those of the origin of life . . . and their primordial germs must be coeval with the dawn of matter and with time itself."

In the fullness of time, perhaps one hundred million years ago, when all conditions were favorable, there somehow arose and spread in the primordial sea, which then bathed the globe, a highly complex substance whose every molecule was composed of hundreds of atoms, which again were composed of hundreds of electrons, and all so highly and peculiarly organized as to support life. Not only on this earth but possibly on millions of stars has this vital substance, protoplasm, appeared, subsequently, to assume countless forms and functions. No one knows how many the ages and the stages it took to bring forth even this primitive protoplasm, which anciently was structureless. Ages again elapsed before it evolved into definite, individual forms like the amoba of to-day.

The amouba is the most interesting and suggestive creature under the sun. In the amœba life is reduced to something like elementary terms ; not absolutely elementary, for even this humble creature is "the terminal of a vast past, as well as the germinal of a vast future." But, roughly speaking, the amœba represents a simple archetype from which all the life forms in the animal kingdom have sprung, and the prototype of the embryo of every vertebrate, including man. In such a microscopic and microcosmic bit of protoplasm are, and were, packed all the manifold possibilities of life.

Two students, who watched an amœba continuously for six days and five nights, declared that they saw in the drop of water under the lens of the microscope scenes so vividly dramatic as to be hardly describable without anthropomorphic terms. There is danger of nature-faking here, as in all 
interpretations of animal life, but the following can at least be said of the amœba: first, "he" is sensitive to light, heat, mechanical, electrical, and chemical stimuli, to jars and shocks; second, he moves as much as one hundred fortyscren millimeters in ninety-six hours, - that is, he swims by thrusting out extemporaneous arms or legs, and lopes by lengthening and shortening his body as a whole; third, he rests, - that is, he reposes after activity, and the rest and activity are proportionate to each other, following each other rhythmically; fourth, he eats, - he seems to detect a
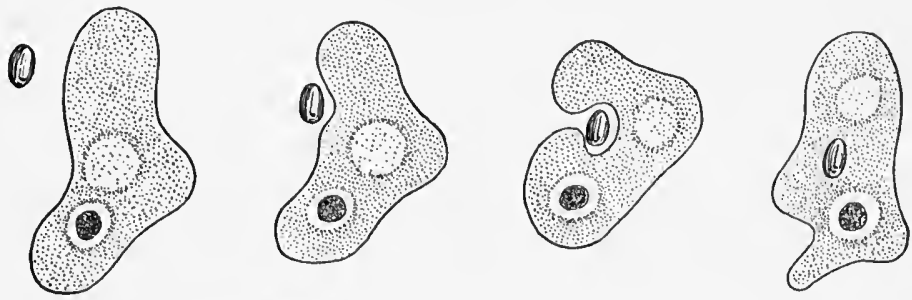

Fig. 4. An Amceba pursuing and swallowing Foon

(From Gulick's "Control of Body and Mind")

paramecium even at a distance. He pursues his prey sometimes as long as twenty minutes, closes the pseudopods about the struggling victim, and squeezes him to "pulp."

The marvelous thing is that a unicellular bit of matter can perform all these essential functions. It is interesting to contemplate that such simple protozoans may once have been the sole representatives of life on this earth. Nature did not intend, however, that they should be the kings of creation, and that all types of life should remain tiny and aquatic.

... The continents emerged from the depths of the sea; some say the moon was hurled, as a seething, catastrophic mass, from the mother earth; valleys and river beds took shape, and in the rank vegetation lumbered the reptiles of 
gigantic bulk and name. Tremendous is the gap between the microscopic amœba and the enormous diplodocus, the hugest animal that ever lived. And so it came to pass that the tribe of lizards were once the kings of creation.

How shall we state biologically the difference between the amoeba and the diplodocus? It is multiplication of vells,- differentiation of cells in structure and specialization of cells in function. By all the forces which make for variation and mutation, through natural selection and through other means only poorly known, the multifarious flora of land and sea were evolved, and all the million or more of animal species living and extinct.

With evolution, cells take on different sizes, shapes, properties, and powers. Some serve the purposes of digestion, others of excretion, locomotion, circulation, respiration, coördination. They lose their primitive power of self-subsistence, and persist only in relation to and support of neighboring cells. Cells of one kind can together constitute a tissue or an organ, but not an animal, and the variation in size, kind, and relative preponderance of these different tissues constitutes the manifold differences in the animal world. The earthworm in the dust has almost the full complement of tissues, and sovereign man is like the worm in that he consists primarily of a digestive tube; but superimposed upon this tube are structures and organs relatively more perfect and important in him than in the worm. Impersonally speaking, the most radical difference between the two creatures is this: the worm has only a few long, complex neurons; man has millions upon millions.

The neuron may be instructively compared with the amœba. Both are single cells, microscopic bits of protoplasm with a nucleus and cytoplasm. But while the amœba has the power of locomotion and self-subsistence, the neuron 
exists and has importance only by virtue of its relationship to other cells. The neuron when mature, unlike the mobile amceba, has a definite shape and size. Typically, it has a diameter of, say, one two-hundredth of an inch, and has two processes, - the dendrite, which is comparatively short,

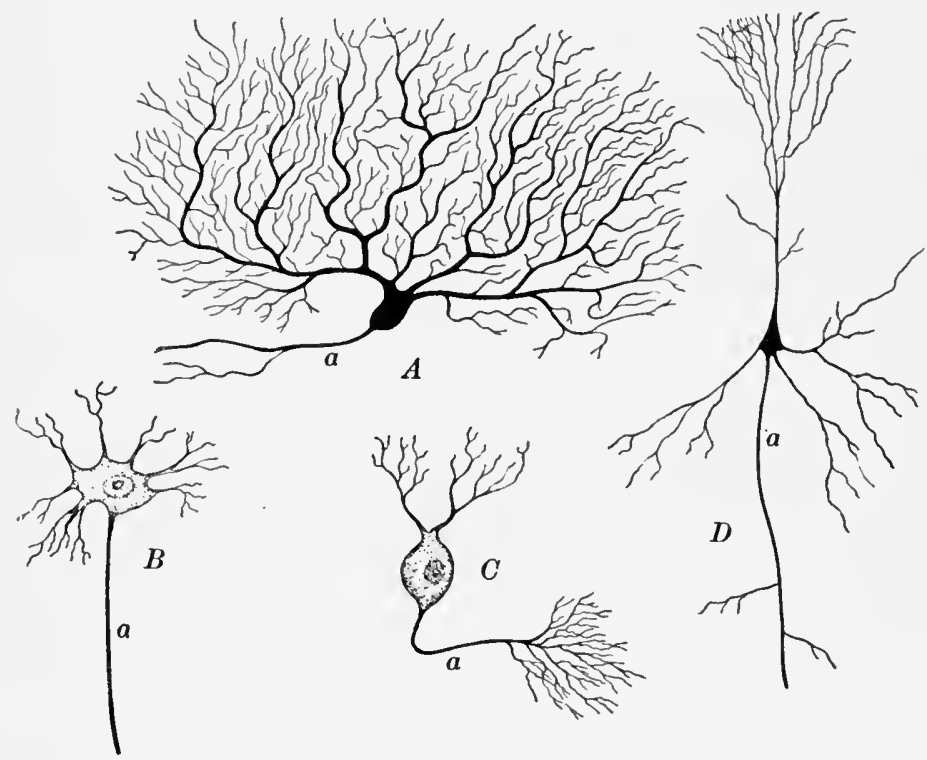

Fig. 5. Four Neurovs

$A$ and $C$, from the cerebellum; $B$, from the spinal cord; $D$, from the cerebrum; $a$, the axon. The cells $A$ and $D$ are stained so that the cell body and the dendrites are black; $B$ and $C$ show the nucleus. (From Gulick's "Control of Body and Mind ")

tapering, grayish, and branched like a tree; the neurite, which is longer, and may be wrapped in a whitish, medullary insulating sheatl. The neurite usually has short branches at right angles (collaterals), and an end tuft of tiny fibrils. Neurons differ enormously in shape and size: some look like hairy gourds, others like baskets or irregular spiders, 
and still others resemble long trailing vines. The fibers, though unimaginably small in diameter, are over a yard long when they reach to the toe tip or other distant point of the body.

The neuron represents the acme of specialization. If all the manifold cells of our body were arranged in a hierarchy, the neurons would surely be perched highest, for they are the sentinel and captain cells which bring all the organs and functions of our body into harmonious coöperation. They are also the basis of all conscious behavior, and it is through them that we become adjusted not only to our biological but to our social environment.

There are three types of neurons, - the sensory, motor, associative. The sensory neurons are the most primitive. They constitute the innumerable outposts seattered throughout our sensitive periphery. There are hundreds of thousands of these which end freely in the skin or terminate in microscopic end organs. The cell bodies of these cutaneons neurons are massed in the thirty-one pairs of spinal ganglia, enlargements of the spinal nerves arranged like beads along the spinal cord. These are the neurons which are responsive to pressure, warmth, cold, and pain stimuli. Similar neurons terminate in the sensitive linings of the internal organs, in the tendons, and in the joint surfaces. Tiny specialized neurons are located in the retina of our two eyes, the rods and cones; in the organs of corti of our two ears; in the mucous membrane of our nose and mouth. All the neurons which have to do with the manufacture of afferent or inward impulses and their transmission are sensory.

The motor neurons also have a wide distribution, for they supply the many muscles of our body from sealp to toe, - . the end organs of movement, which constitute 43 per cent of our body's bulk. They also connect with certain glands, 
like the perspiratory and salivary. These neurons carry the outward or efferent impulses, which result in many responses, from the reflex eyewink, or watering of the mouth, to the pitching of a baseball.

The associative neurons are neither afferent nor efferent in character. They are central in both position and function. They lie between and about the neurons which simply receive and clischarge stimuli. Their business is to centralize, organize, shunt, adjust, regulate, inhibit, and record stimuli. Their

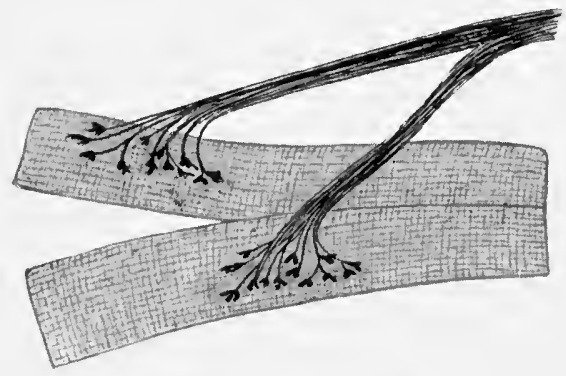

Fig. 6. Exding of Axons of Motor Neurons in Voluntary Muscle Fibers (Highly magnified) peculiar plasticity, or memory, makes it possible for them to retain past experiences and to modify present reactions not only in terms of present stimuli but in terms of the past and even of the future. The bulk of the brain consists of associative neurons.

Indeed, the whole nervous system is essentially nothing more than the grand total of its millions upon millions of neurons. Of course the nervous system also contains fibrous connective tissue in which these neurons are enmeshed, lymph in which they are bathed, and blood vessels which carry their nourishment. But these are only accessory structures. The anatomical and functional elements are the myriad of neurons, - a myriad unthinkably great, for Thorndike has calculated that it would take an industrious duo-centenarian to count all the neurons in a single human being. Put a hypothetical forceps anywhere in the nervous system, pluck a dendrite, pull, and you 
could lift out a whole neuron. That is, neurons are not welded into each other; they are anatomically independent; they touch without fusing. But this does not mean that they do not coöperate; for, junglelike and bewildering as the nervous system appears under the microscope, it is not a chance tangle. In every sane, normal being, orderliness and law prevail in the multitudinous impulses which dart in every direction through the mazes of dendrites and neurites.

The neuron concept emphasizes the tremendous complexity of the nervous system, but also makes more comprehensible the main principles of its mechanism. Neurons are the essential elements of the end organs and of the nerves. A nerve is a dense cable of parallel neurons plus accessory tissue. The spinal nerves consist of both sensory and motor neurons ; the cranial nerves exclusively of either, and sometimes also of both. The spinal ganglia are collections of sensory cell bodies, thickenings of the nerves. The central gray column of the spinal cord consists of associative neurons, the end tufts of sensory, and the cell bodies and dendrites of motor neurons. The white matter of the spinal cord consists of the medullated strands of ascending and descending fibers continuous with or joining the sensory and motor neturons which make up the thirty-one pairs of spinal nerves. These sensory and motor tracts constitute the spinal projection system, so called because they project upon or terminate in the cerebral cortex.

This cortex is the most wonderful and interesting structure in the whole nervous system. Every point of this thin, grayish, shirred rind, half a square yard in extent, is connected directly or indirectly with every other part of the nervous system. As Meynert has put it, the cortex is a projection surface on which every muscle and sensitive 
point of our whole body is represented. Even the sympathetic nervous system which controls the vegetative functions of respiration, digestion, and circulation, and

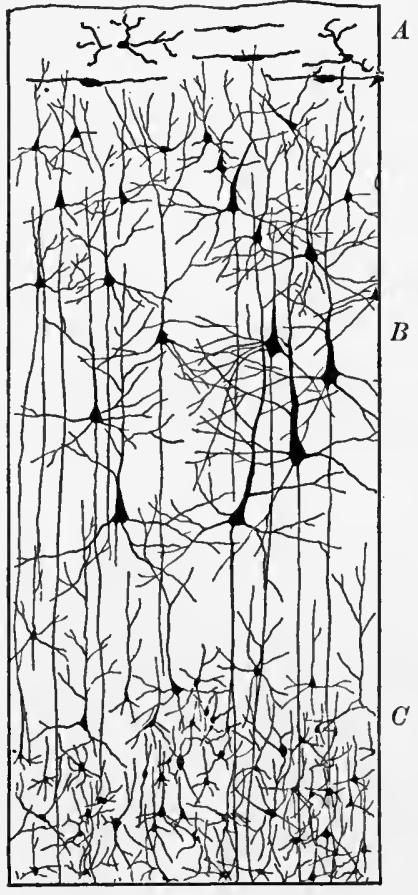

Fig. 7. The Neuron Layers of the Cerebral Cortex

A microscopic section showing: $A$, outer layer of Cajal cells; $\boldsymbol{B}$, middle layer of small and large pyramidal cells; $C$, inner layer of polymorphic cells. (After Piersol) which, because of its independent nature, is sometimes called the autonomic system, has vital connections with the cortex. 'The large white core of the brain is also continuous with the cortex. It consists of a compacted mass of connecting fibers which join the cortical neurons with every portion of the whole nervous system, near and remote, and make the cortex a switchboard marvelous beyond man's conception.

There are three distinguishable systems of fibers : ffirst, the sensory and motor fibers, which connect with all the muscles and end organs of the body 'both above and below the neck; second, the transverse association fibers, which join opposite hemispheres ; third, the longitudinal fibers, which join adjacent and remote parts of the same hemisphere. 'This secluded organ, the cortex, was not even named, much less appreciated, in prescientific ages. In an earlier chapter we have told how its intricate structure and hidden wonders were revealed by the methods of modern neurology. The 
microscopic investigations, notably of Cajal, have shown a dim stratification of three or four layers of complicated neurons: the outer layer of longish Cajal cells, the middle one of large and small pyramidal cells, and the inner one of polymorphic cells. Photographs alone can give an adequate realization of the complex structure of the cortex, and diagrammatic thinking on the reader's part some conception of its mechanism and function. The cortex is gray, because, like the core of the spinal cord, it consists chiefly of cell bodies and dendrites. Gray matter is popularly associated with mental caliber, and properly. The millions of bits of protoplasm and their treelike processes, of which the cortex is formed, are the instru-

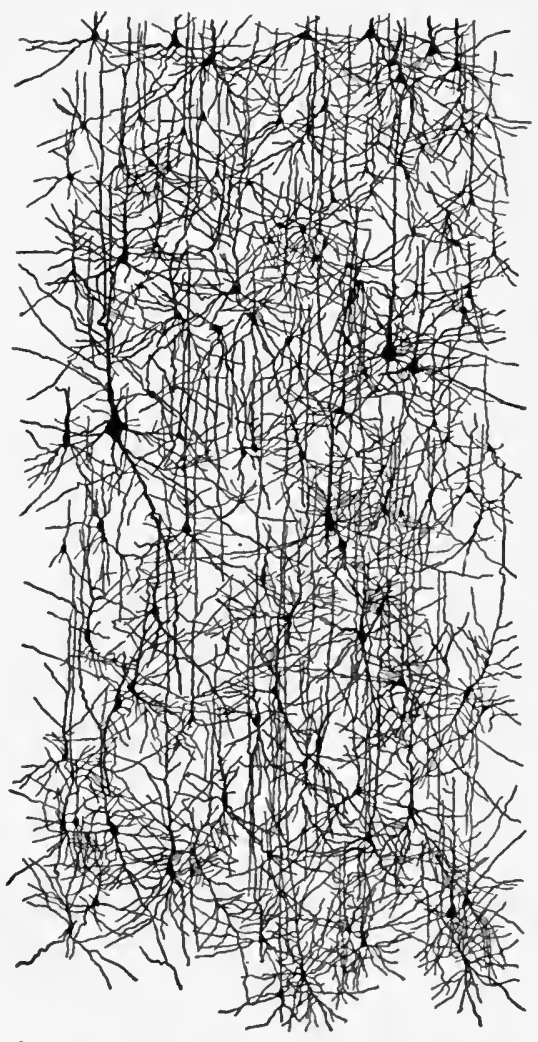

Fig. 8. Portion of Cortex stained to show its Marveloushy Rich Fibek Texture

(From Gulick's "Control of Body and Mind." After Kölliker) ments and organs of all thought and feeling. The white fibers and nerves transmit the impulses to and from the captain organ, the cortex. 
The development of associative neurons in particular is correlated with the development of intelligence in the race and in the individual. Other things being equal, mental growth depends upon the number and complexity of associative neurons. The gross number in any child is absolutely determined by heredity. The idiot has fewer than the imbecile, and the imbecile may have fewer than the normal person. Though the full quota of neurons is provided at birth, most of them are undereloped in early infancy. awaiting the touch of time and training. Only with months and years of experience do they grow and take on organization. Such organization and increasing complexity in the neurons also seem to be characteristic of the different stages in racial derelopment. Cajal has arranged in an ascending series typical neurons from the lizard, frog. white rat, and man. They show a progressive elaboration in the dendrites.

The superiority of man is further reflected in the extent of his association areas. Those areas of the cortex which are directly and chiefly connected with the sense organs are called sensory; those which directly connect with muscles, motor; and the intermediate areas - frontal, parietal, occipitotemporal, and the island of Reil - are the association areas. The latter do not connect directly with the end organs of sensation and movement, but are supplied ehiefly by association fibers, which in myriad ways connect these association centers within themselves and with each other.

A survey of the evolution of the nerrous system will bring out the significance of the association centers. The amoba, of course, has no neurons, neither has the sponge. The microscopic contractions of the circular muscles about the pores of the sponge result upon direct stimulation. The sponge is one of the very rare creatures in which the muscular cells and nerve elements are not found together. As 
a rule they are interdependent and inseparable, and really constitute one indivisible system, the neuromuscular system:

The sea anemone is a tiny, mobile digestive pouch, armed with active tentacles. Throughout its body walls are many muscle cells and simple neurons, both sensory and motor, which connect with the muscle cells and control their activity. The neurons of the sea anemone and the closely related hydra are diffusely scattered, and not compacted into nerves, ganglia, sense organs, or brain, but, by courtesy, they constitute a rudimentary nervous system.

The insects represent a very ancient form of life on this globe. In them the nervous system is well developed. When Charles Darwin contemplated the wonderful possibilities of behavior residing in the frontal ganglia of an ant, he almost concluded that this tiny bit of nerve tissue is the most marvelous atom of matter in the universe. The insects, however, belong to a side branch of the tree of life, and so we pass to the earthworm, who is part of the main trunk.

The earthworm is biologically higher than the sea anemone. It is not so exclusively a digestive tube. It is well upholstered with muscles which make true locomotion possible. The increase in complexity of life in the air and on the ground was attended by the development of respirattory, excretory, and circulatory organs, and a real nervous system. The earthworm has true nerves, some seven hundred and twenty of them, - three pairs for each segment; a long chain of ganglia known as the ventral nerve cord, and special anterior ganglia, or a rudimentary brain. But there are only three giant nerve fibers to bind the various parts of the nervous system together. The remaining number of neurons are stubby, so that the system as a whole is highly segmental. The worm does not even have 
a true spinal cord. In the amphioxus there is a dorsal rod of cartilage, which in the vertebrates becomes a backbone incasing a true spinal cord.

The ancient history of our old earth is recorded in the successive geological strata. Scores of millions of years ago this process of stratification began. Similarly, the biological history of man is reflected in the successive superinposition of system upon system, organ upon organ, part upon part in our own old body, which has its archæological traits like the earth itself. Our primitive digestive tube dates back to and is knit by heredity with the primitive digestive pouches of a Paleozoic age. Indeed, as Parker has pointed out, our intestinal walls in cross section reveal a neuromuscular mechanism substantially like that of the sea anemone. Tyler neatly summarizes the significant facts about the almost stratified human muscular system, as follows: "Different parts are of very different age. Our trunk muscles originated in worms; those of shoulder and thigh in fish; those of arm and leg in amphibia; the hand, as such, was developed by arboreal mammals; the central portions are older, the peripheral younger."

The nervous system, which is so closely related to the muscular, has therefore naturally evolved somewhat on the installment plan, from fundamental to accessory. Although it is now knit into a highly unitary whole, it still reveals its accretive character. Its most ancient portion is represented by the spinal cord, which controls the fundamental body reflexes. The spinal cord dates far back beyond the Devonian age. We share it with the lowest vertebrates. The medulla, cerebellum, and basal ganglia were all in the nature of subsequent installments; but these too are ancient when compared with the cerebral cortex. In the fishes the cortex is nonexistent, or little more than a seat for smell. 
In the reptiles it is small. smootl, and slanting, and chiefly a sensory and motor center. The enormous Mesozoic dinosaurs were gigantic in brute strength but feeble in wit. Their muscular activities were large, clumsy, and crude. The Tertiary mammals developed the power to run, jump, frisk, burrow, and clamber. These more complex activities required a larger number and more delicate arrangement of neurons for control and coördination. With the enrichment and differentiation of movement the cortex grew in both size and complexity.

Proceeding up the animal scale, we find a substantial similarity and stability in the lower nerve centers, cord. medulla, and cerebellum. The advancing portion is the cerebral cortex, which keeps on deepening. furrowing. and expanding. until fually, in the human species, the lower nerve centers are literally smothered under its bulging preëminence. So progressive and marked is this development that it has been said that the

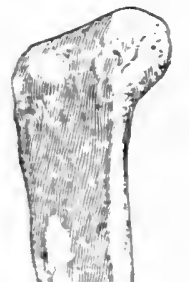


The gross facts in regard to the evolution of the racial cortex are diagrammatically shown in the accompanying figure. The microscope reveals even more interesting texture differences between the cortex of man and that of the

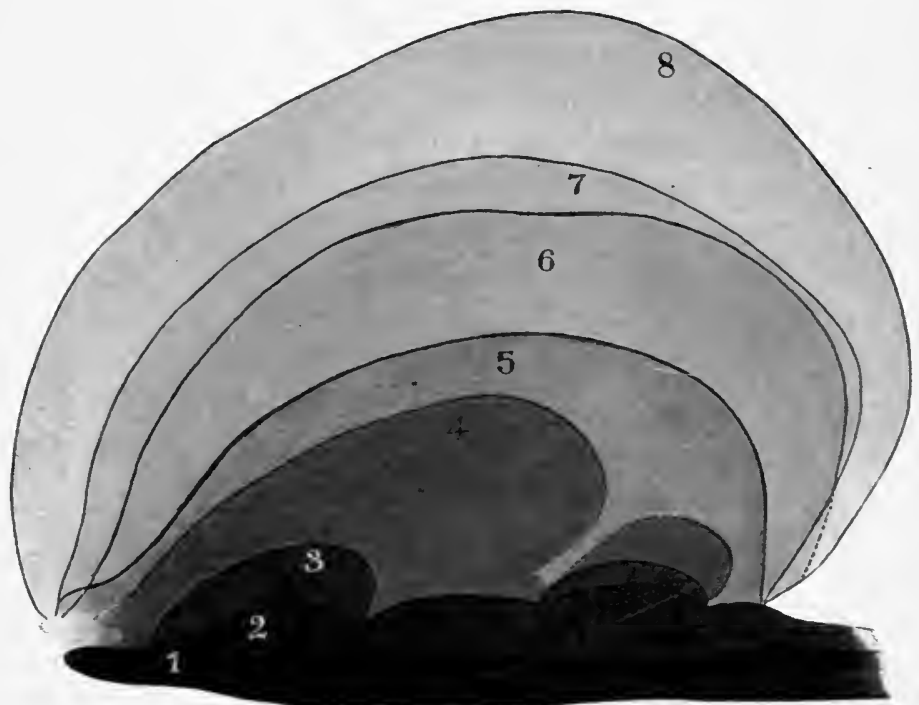

Fig. 10. The Erolutiox of the Cerebral Cortex

Composite diagram of profiles : 1, Amphioxus (cortex absent); 2, fish (cortex rudimentary); 3 , reptile (cortex thin and relatively small); 4 , mammal (development of cerebrum becoming marked); 5 , chimpanzee (the most nearly human arboreal mammal); 6, Pithecanthropus erectus (the man of Java, with the lowest known human cranium; see Chapter V); 7 , the Neanderthal man (a paleolithic German whose brain cap was found associated with the remains of rhinoceros and cave bear) ; 8, Papuan (one of the lowest of present savages, with a cranial capacity intermediate between the primitive and modern European)

lower animals, and brings out the encouraging fact that growth or medullation of the neurons continues in the human association areas as late as middle life. There is reason to believe that the period of plasticity in the racial cortex is being gradually prolonged, and that in a future 
age the many neurons in the prefrontal region, at present undeveloped, will be called upon to meet the stimuli and stress of an increasingly complex environment.

In the nervous system, mind and body, impulse and energy, psyche and soma, are in closest union. If there is psychic heredity as well as physical heredity, it is because the child inherits the nervous system of his parents. And if there is a kind of racial psychic heredity, it is because science has shown the nervous system of the child to be biologically continuous with that of his forebears. Instincts are modes of behavior acquired by the race and perpetuated in each new generation by the transmitted organizations and predispositions of millions of neurons. Thus fear and anger are as ancient as the frog; thus all the vital and enduring interests and experience of ancestors, of primitive man and his prehuman progenitors, tend to survive in the behavior of descendants, and the spirit of the past flickers up again in the unfoldment of every individual nervous system. 


\section{CHAPTER V}

\section{THE PRIMITIVE ANCESTRY OF THE CHILD}

Man is a migrating animal. We are all descended from immigrants. This migratory propensity is at work now. It was at work in prehistoric times. It moved even our prehuman ancestors. As a result, man very early settled the wḥole globe.

Once upon a time this globe was not habitable. It was either a semimolten mass or a barren mineral sphere. Now our cities are built on a sedimentary masonry thousands of fathoms deep. How long did it take nature to evolve this crust, some fifty miles thick, on which we live? Four vast epochs, - the Paleozoic, the Mesozoic, the Tertiary, and the Quaternary, aggregating, according to one geological estimate, some one hundred million years.

Three fourths of this vast span belong to the Paleozoic period. In this period the most ancient stratified crystalline rocks - quartzites, gneiss, and limestone - were developed. In this era also were developed the most primitive forms of animal life, so viscirl that they could not persist in fossil form. With the lapse of millions of years there appeared in due succession, through the gradual processes of transformism which have operated since the dawn of time, worms, crustacea, brachiopods, fish, amphibia, and reptiles.

Representatives of all these genera appeared before the close of the long Paleozoic era. In the next era, the Mesozoic, which lasted some ten million years, the reptiles some of which attained an enormous size - came to their 
lordship of water, air, and land. This period also produced the archæopteryx, with toothed bill, vestigial wing-claws, and jointed tail feathers, - an early, uncanny bird, bearing all over the marks of his reptilian ancestry.

The lowest Mesozoic mammals, likewise, were closely allied to an ancestral reptilian form. The young of the monotreme to this day completes its development in a hatched egg. The marsupial mammals, who carry their offspring in a protecting pouch, or fold of the skin, originated in Mesozoic times, while the higher placental mammals did not appear until Tertiary. The Primates, who constitute an independent order of the placentals, include the half-apes and the Anthropoidea. According to the zoölogical classification the Anthropoidea are subdivided into five families, - the marmosets, the American monkeys, the tailed and tailless apes, and the Hominidæe, or man himself.

The Tertiary era began some four million years ago. Even in this remote age the world had taken on many of its modern aspects, and could we have visited a mid-Tertiary meadow we should have seen enough familiar plants, grasses, flowers, insects, birds, and beasts to feel not altogether strange. The forests numbered oak, pine, cypress, spruce, and maples. Bees hummed, butterflies played in the sunshine, and birds sang. Most of the world was perennially bathed in warm weather. California sequoias grew as far north as Greenland, magnolias in Canada, and palms flourished over northern Europe. Not only the hyena, cave bear, and bison, but tropical and subtropical animals like the lion, rhinoceros, hippopotamus, and elephant ranged throughout Britain and the continent with which it was still continuous. Sumatra and Java, like the British Isles, were then part of the mother continent. What is now the blue Mediterranean was a broad stretch of jungle and 
prairie, alive with the colors, movements, and sounds of African fauna. In this region, where the great civilizations of the world were to plant their seaports, all was now a savage wild. France flared with abundant volcanoes, for in this period the earth's crust was extensively unquiet, warping into plateaus and buckling into lofty mountains. On one occasion an eruption in tropical Java buried a multitude of living beings.

Several hundreds of thousands of years later Professor Dubois made excavations in the neighborhood of this eruption and unearthed masses of old bones from Tertiary elephants and other large mammals. Among these relics were a skull cap and thigh bone which prompted the interest of the whole anthropological world; for these two bones made it certain that a creature with human characteristics walked erect in Pliocene antiquity.

The ambiguous name of this being, Pithecanthropus erectus, suggests his primitive character. He had the jaws and protruding brow ridges of a gorilla, but a cranial capacity little less than that of the lowest living savage, and twice that of the highest ape. If not the first man, he represents at least man's immediate precursor.

It should be said, parenthetically, that this does not mean that the ape is a degenerate man, or that man is a developed monkey, as uninformed people declare. Man is not descended from a monkey. Man and ape represent each a distinct species, equally descended from a common generalized prototype. 'This generalized, human-simian ancestor' was the remote precursor of man, and lived in Miocene times, say a million years before Pithecanthropus erectus. It should also be said that in this chapter we are trying to tell a simple narrative, and not attempting a critical discussion of the moot questions concerning the history of man. 
There are wide differences in interpretations and chronological estimates, and many matters are not settled. But that there have been genesis and growth, and a long, long period of development, every one nowadays agrees. For the teacher many of the details in geology and theories of descent are not important. But the genetic point of view, the feeling for the ancient biological antecedents, the psychological heredity and unfolding, the listorical, recapitulatory significance of childhood, - this is important. These large themes are surely worthy of some reflection by those who are dealing with growing children.

There is good reason to believe that the Indo-Malay country, where Homo Jaranensis lived, was the cradleland of humanity. According to A. H. Keane, who holds the monogenetic theory in regard to human origin, the race had here its first center, and from here it dispersed to ultimately people the globe. "These generalized pleistocene precursors," he says, "moved about like the other migrating faunas unconsciously, everywhere following the lines of least resistance, advancing or receding, and acting generally on blind impulse rather than of any set purpose."

Should we not have the courage of thought to picture to ourselves the character of these early migrations and immigrants? There were, even in these rude hordes, mothers, fathers, and children, holding each other now and then by the hand, giving signals of warning and distress, assisting each other on the march. But these early forebears were indeed rude in outward aspect. Their eyes were peering and set deep under enormous brow ridges; their lower jaws, large and strong. They wore no protecting garment other than their own semishaggy coat. Agile in their native homes, the trees, they walked the earth with clumsy gait, their broad shoulders stooping, their knees bent. The 
immaturity and imperfection of the sprawling infant do not excite disgust. Why should we not look with equanimity at least upon these first scenes in the childhood of the race? This rude progenitor, though he traveled not by map or car, had within him the germs of the whole atlas of human culture. He already possessed the rudiments of speech, which is the instrument of all civilization. He could break a branch and fashion it to serve a simple purpose; this is the ability to make and use tools, and is the root of all mechanical achievement. The children clung to their mother's; the male fought and foraged to preserve mother and child. Even in the rough hordes the outlines of family life had emerged. There was parental sympathy, and this is the root of all morality.

Those who desire to speculate about the mental traits of this most primitive human type can get suggestions from the psychology of man's nearest anthropoid relative. Studies in the laboratory have shown that, even under the rather artificial conditions of captivity, the American monkey has a high degree of intelligence or associative memory; that he has a certain amount of practical judgment, which is a simple form of reasoning; that he does not learn exclusively by the mechanical process of trial and error; that he can imitate in a purposive, productive manner. Dr. Kinnaman's two monkeys, Jack and Jill, learned to thread a complieated maze of seven blind alleys and twenty-seven corners in one hundred thirteen and sixty-six trials respectively. They also solved certain mechanical puzzles with the same rapidity and success as a doctor of philosophy.

A most suggestive and intimate account of "A Monkey with a Mind" has recently been furnished by Dr. Lightner Witmer. Peter, strictly speaking, is not a monkey, but a chimpanzee. The chimpanzee in many respects comes 
nearest to man. His arms are much shorter than the gorilla's, reaching only a little below the knees; he also has a betterdeveloped head, great toe, and thumb; his whiskers, eyebrows, lashes, and teeth approach the human in character; he is said to be naturally more tractable and social, living not only in family groups but in parties of several families; the male builds tree shelters for the female and young, and sleeps lower down to protect them.

Peter has been taken away from his African arboreal environment, has been put into evening clothes, and brought before the audiences of large cities. To come at close range with Peter's powers, Dr. Witmer made several private examinations, and finally brought him before his psychological clinic, subjecting him to certain mental tests used in diagnosing the intellectual grade of backward and defective children. All these observations resulted in the interesting conclusion that Peter ranks upon the plane of a low or middle-grade human imbecile. He has decided motor dexterity; he skates on roller skates, learning by himself in a few hours; he rides a bicycle, drinks from a tumbler, eats with a fork, threads a needle, lights and smokes a cigarette, strings beads, and puts pegs in a board; he shows a high degree of practical judgment in opening a strange lock and selecting a needed key from a key ring; he can use a hammer, drive a nail, drive a screw, and select the proper screw driver for his purpose; he partially succeeded even with the classic test of inserting various geometrical blocks into a special form board with shallow depressions; but most mirabile dictu, after a $\mathrm{W}$ had been drawn on the blackboard he copied it in direct tracery imitation. He can articulate "mama," and learned in a five-minute phonic drill to pronounce "P." He shows decided powers in comprehension of language. His emotional traits are no less 
wonderful, for his mobile face expresses in turn nonchalance, eagerness, disappointment, courage, distress, protest, inquiry, affection, and "at times he even has something very like a momentary grin of humor, albeit ghastly because of the cavernous mouth and huge jaw."

It has been suggested that the apelike man of Java may be regarded as an intermediate transitional form which fills the anatomical gap between modern man and his brute ancestors. There is a similar psychological gap or chasm.

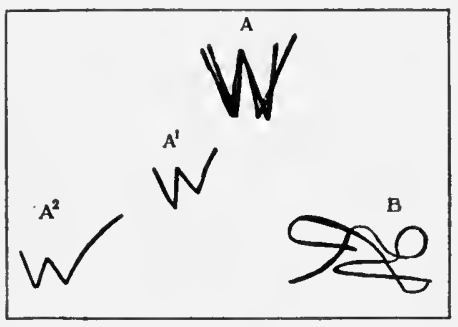

Fig. 11. Peter's Whitixg on the BLACKHOARI

$A$, the letter W drawn twice, one tracing over the other; $A^{1}$, Peter's copy after the second tracing; $A^{2}$, Peter's second effort when told to make a W again; $B$, a scrawl following the first tracing

This chasm, Dr. Witmer holds, Peter's mind practically bridges. Since mind cannot be preserved for us in osseous fossils, we cannot look elsewhere for a bridge or link. When we reflect that many cases of feeblemindedness are really to be interpreted as instances of arrest of development on a primitive racial level, a very significant and legitimate conclusion is that " the study of this ape's mind is a subject fit, not for the animal psychologist, but for the child psychologist."

To come back to the first dispersion of the human species. No one can, of course, say how long it took for man to spread over the whole habitable globe. His rate of increase may have been fast, but, while nimble in the trees, his progress on the ground must have been gradual. The climate, however, was uniformly mild, and his complete occupation of the world was probably under way by the close of the Tertiary epoch. In this remote age there were of 
course no nations, - not even races. This early man was a generalized ancestor, from whom the four primary divisions of the human species - Negro, Mongolian, American, Caucasian - were not to diverge until hundreds of thousands of years had elapsed.

The home of most primitive man was like that of the Swiss family Robinson. Not only in appearance, but to some extent in habits, he must have resembled his nearest kin. His food consisted of roots, berries, plants rich in cellulose, nuts, honey, and insects. He had few ornaments of beanty and tools of utility. Some writers have even questioned whether he had the cortical neurons that would enable him to talk. At any rate his utterances were thick and clung to the base of his tongue; for nimbleness and subtlety of articulation go with the development of abstract ideas, of which he possessed very few. His life was probably arboreal until the increasing cold climate drove him into caves.

With the close of the Tertiary epoch a great meteorological and geological change came over the earth, which had a powerful effect upon the natural history of man. Mysterionsly, from the north, crept a great ice cap, which covered a good part of the northern hemisphere with glaciers and icebergs. As mysteriously it retreated, to reappear at least once again. In the warm interglacial period - a duration of perhaps five hundred thousand years - the first achievements of truly human culture were made. In this period fall the eolithic and the paleolithic age, - the latter lasting, according to Keane, about three hundred thousand years. Even though these figures are but an estimate, they will serve to impress the thoughtful reader with the comparative brevity of our historical era, the ancient lineage of our civilization, and the very primitive ancestry of the morlem child. 
Paleolithic man - and woman too - was a hunter. The ice invasion may have exterminated some of his most dangerous foes, but there were enough ferocious species left to call forth all his fear and fight and cumning. His contemporaries, although he liverl as far north as England, were the cave bear, the cave lion, the cave hyena, the wild ox, wild boar, wild horse and wolf, hippopotamus, and woolly rhinoceros. But most terrible of all was the huge, sabeltoothed tiger, with his enormous jaw, his dagger teeth, and

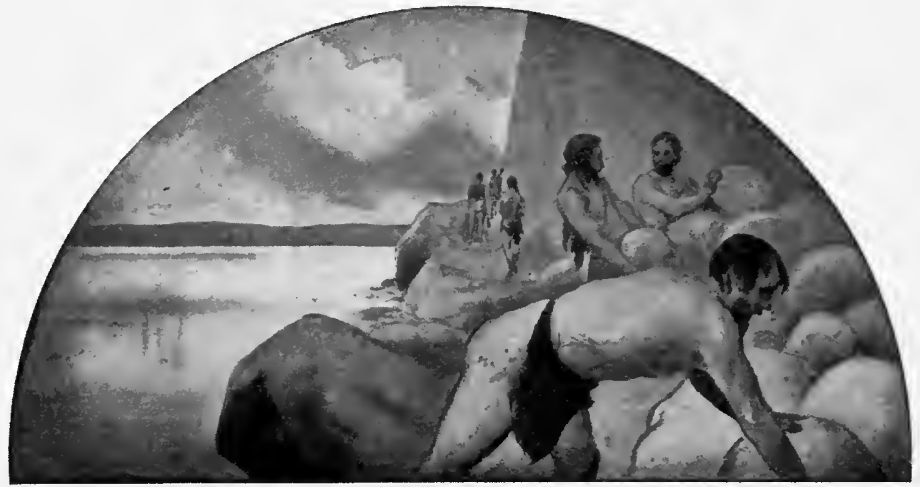

Fig. 12. The Cairn

(From the painting by John W. Alexander in the Congressional Library)

powerful wrenching neck muscles. This most deadly of all beasts struck terror even to the shaggy-maned mammoth. With such enemies, and no protection but the caverns and overhanging cliffs, the primeval savage was put to his wit's end. In the beginning he did not even have fire to drive the wild beasts away. The night was utterly dark, filled with ominons silences and terrifying soundsbellowing, splashing, roars, snorts, and howls; and if he heard the voice of his own humankind, it usually was nothing more than jabber, grunt, or cry. 
But though he had not the brute strength of the beasts, he had intelligence in greater measure than any of them. Intelligence is the capacity to profit by experience. It depends upon a nervous system plastic enough to form habits. Professor Yerkes built an experimental aquarium to test whether the frog has such a nervous system. A hungry frog was introduced at the aperture $a$, shown in the accompanying diagram. The question was, Would the frog learn the direct route $a-b$, or would he do no more than instinct prompted him; that is, move about aimlessly and unintelligently? He proved to be educable. After some

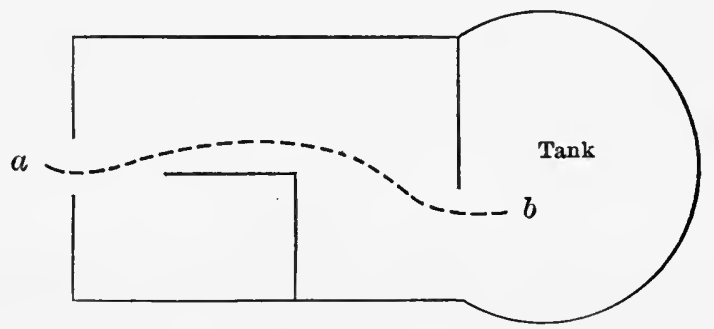

Fig. 13. Test of Animal Intellgence in the Frog

fifty to one hundred trials he pursued the proper path, and when retested a few weeks later showed that he had retained his acquisition. The ability and propensity to swim, snap at flies, and hibernate were provided by nature in the inborn constitutional organization of the frog's nervous system. Habit formation, on the contrary, depends upon the connections between neurons which are established only through the touch of experience. Intelligence does not supplant instinct, but supplements it. Both instinct and intelligence increase with the evolution of the nervous system. Primitive man, therefore, was superior to the animals with whom he contended in natural instinctive endowment 
as well as in capacity to lear11. This double advantage made him in time the one universal, dominant species.

He succeeded in paleolithic times in planting himself over the whole habitable earth. His rude relics have been found the world over. 'The stones which he at first only hurled, or piled as a safety wall at the mouth of his cave, he learned to fashion, by breaking and chipping into various implements, - spearheads, axes, knives, saws, and scrapers. He gradually grew in his power to make tools and to contrive. He learned to fasten a heavy stone to a lance, to

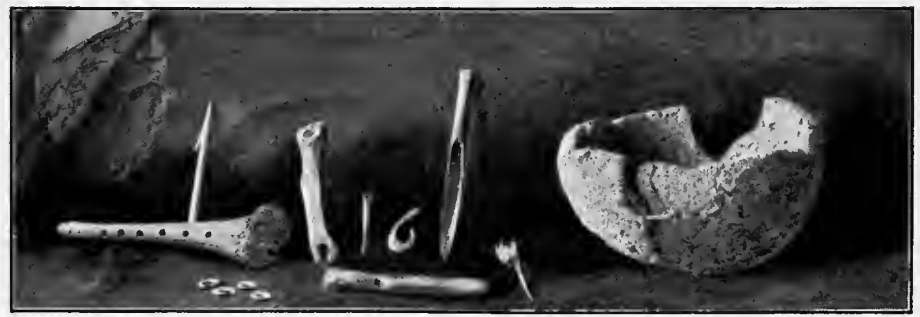

Fig. 14. Bones transformed by Catalina Indaxs into Flute, Lance Head, Hide Smoother, Needle, Fismook, Awl, Spoon, axd Bowl (From a photograph of a collection at the Southwest Archæological Museum, Los Angeles)

give it death-dealing force when dropped upon a mastodon or sabertooth. He also made pitfalls, snares, and traps. When the hunt was successful all gathered around the carcass, drank its warm blood, ate its raw meat, and sucked the nutritious marrow from the bones. We need not shrink from the picture, for the near descendants of this same savage marle awls and borers of the bones, etched drawings upon them, and even made flutes of them to bring forth music. Paleolithic man was not merely a gnawer of bones. Nor must we forget, as Spencer has reminded us, that out of these same savages came at length our Newtons and Shakespeares. 
Before a Newton came, however, the race had to pass through several more primary grades of culture. The paleolithic period in Europe came to a close, roughly speaking, with the disappearance of the last ice sheet. That was about a hundred thousand years ago. Of these one hun dred millenniums, seventy belong to the neolithic period, twenty to the metal ages, and ten to historic times (Keane's estimate).

The neolithic age was a golden period in the larger history of man. It has been questioned whether he has ever since shown quite so much creative power. In this period language became organic; religious ideas developed; social groups were formed by the combining of families and clans; pile dwellings and kitchen middens, ditch dwellings and circular huts, were built for the living; graves were dug for the dead; sepulchral chambers and monuments, megalithic and monolithic, were reared the world over. 'The art of stock breeding, of making polished stone implements, spinning, weaving, mining, and pottery were all begun. Both plants and animals were domesticated, - cereals and vegetables, fruits, dogs, sheep, horses, and cows. But the supreme achievement was the conquest of fire; neolithic man domesticated fire, and fire domesticated him.

How the picture changes when fire lights up the dark, repelling the prowling beasts, brightening the gloomy cave, and drawing whole families to its friendly warmth! Fire worked a revolution. Woman became the fire keeper; food was no longer eaten raw; cooking brought concentrated instead of bulky meals. This dietary change reduced the stomach capacity and size of the jaw, and freed a vast amount of kinetic energy for man's further uplift.

The first centers of neolithic culture were probably in the favored region of the Nile and the Euphrates, where 
the climate was temperate even during the ice age. With progress in eivilization and increase in numbers migrations became frequent. From the south streamed a tall, dolichocephalic people, who mingled with or replaced their ruder predecessors in Europe. Later, it is thought, hordes smaller in stature, and brachycephalic, came from the East. Still later - perhaps twenty-five thousand years ago - came the migrations of pastoral, Aryan-speaking tribes. This was a twofold invasion - one by tall, blonde, long heads from the Eurasian steppes; the other by short, dark, round heads from Armenia, through Asia Minor. The speech of these probably conquering peoples persists, but as a distinct race they have vanished, mingling with a hundred other stocks already in possession of Europe.

These Aryan peoples had a primitive pastoral culture. They reared herds of cattle, sheep, and goats, and made the dog their friend and helper. They constructed rude wagons by charring and chopping axle and wheels from a single tree trunk. They built round huts of sod and branches, but in the winter they lived in caves. Their clothing was undressed skin, or, later, rough wool and flax. The wives were captured for marriage, and were put to death when the husband died. Yet Keane says, "They were a gifted people, who, more than any other, may be supposed by their very dispersion to have leavened the rude prehistoric masses, thus raising a great part of humanity to a higher social plane."

The Teutonic type of Aryan became specialized in a second home, the Baltic land, from where he later spread over Europe, and still later over most of the world. The Germans described by Tacitus represent the primitive man who lies closest to us in point of time and culture, and with many of us in direct blood relationship. It surely is 
interesting to contemplate that the forebears of that boy in the front seat, only two thousand years ago, were lounging and hunting in the woodlands of Germany, "loving indolence and hating tranquillity," - superstitious, loyal, brave, brutal, and highminded forest children, clad in the skin of beasts.

Whatever we may think of the culture-epoch theory, there is without doubt a general parallelism between childhood and primitive man. The child has both an intellectual and an emotional sympathy for primitive life. He can appreciate its problems because they are simple, crude, and within his mental grasp. He warms up to the problems because they appeal to his instinctive nature. As Hall has said, "The child is not so much the father of the man as at first his most primitive and half-anthropoid ancestor." Later he evolves into something of a savage and then of a barbarian, if he does not repeat with definiteness the hunting, fishing, pastoral, and agricultural stages of civilization.

Dr. John Dewey, Dr. Katherine Dopp, and Miss Emily Rice of Chicago University have shown in various ways, both practical and theoretical, how the natural bond between primitive man and the child ean be recognized and utilized in education. The teacher who hopes to induct the child into the past must evoke the past in the child. She can do this only by having a warm sympathy for primitive peoples, both living and extinct. To have this sympathy one must psychologize and get into the very motives, fears, failures, joys, capacities, and imaginations of primitive man. Only then can his mythology, the story of his combat with nature, and his industrial achievements be made to tingle with reality. It is no easy thing to get into the soul of primitive man, but it is no harder than to get into the soul of a child. 
That there is a certain psychological identity between primitive man and the child was not proved, but was brought home with all the suggestiveness of a parable, through a simple story recently told by the curator of an archæological museum. This curator, a man of broad sympathies, says that he learns something from almost every visitor with whom he converses.

Once a child came into the museum. To amuse her he spilled a handful of ringlike shells into her lap and told her to play. These shells, which had been found in great

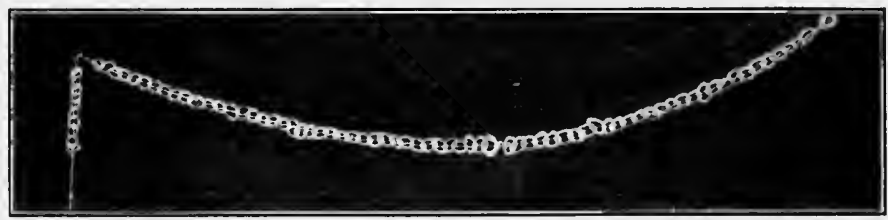

Fig. 15. Necklace of SHFit.s

number's associated with the remains of Catalina Indians, were then the subject of some discussion. The learned ethnologists and anthropologists harl vaguely concluderl that the shells were used as spangles or ornaments. After a half hour's play, in which the child had expressed the same venerable instinct of workmanship which she shared with the extinct Indians, she brought back a beautiful necklace, in which the shells were interwoven simply but effectively in a way which the wise doctors could never have thought out. It was a revelation. A child in natural play restored and repeated a cliapter in the life of a primitive people. 


\section{CHAPTER VI}

\section{INSTINCT AND RELAXATION}

Some one has said that the more we know about the past the less we respect it. This aphorism may be true with certain social conventionalities and pretensions, but it is viciously false with regard to the deepest laws of life. Nature is too unitary and continuous to permit it to be true. The present is born of the past and the past abides in the present, and to understand the present we must appreciate the past. That is the excuse of the two foregoing chapters, which, although they may be but rough sketches, surely emphasize the fact that the child is the product of a most remote and remarkable antiquity.

How far back we trace this pedigree is a matter of taste. Surely we are descended from the neolithic Europeans who lived over a score of millenniums ago, and these in turn were descended from paleolithic ancestors who chipped rough stone implements for some three hundred thousand years. And if we add the vague eolithic period, we may say that the span of man's distinctly human sojourn on this earth measures a half million years. Some would multiply this by two, and if we include the postulated Miocene precursor of man, we shall have to multiply by five or six, or even more. The zoölogist, of course, does not stop even here. He tries to reconstruct the whole tree of life, assigning to the different branches and heights of the main stem a definite geological age. The tracks of worms are found in rocks which we know are scores of millions of years old. The 
evolutionist is sure of our genetic relationship with these same Pre-Cambrian worms. The fish is certainly a zoölogical descendant of the aquatic worm. A student of Haeckel has calculated that the number of generations which lie between the lowest fish and man is fifty millions. To be unconscious of this tremendous range of prehuman and human existence is never to have realized the comprehensiveness compacted in the present.

Comparative anatomy has worked out with surprising success, organ for organ, our minute and gross structural similarity to the lower animals. The psychologist and teacher are, however, chiefly interested in the comparative facts which relate to consciousness and behavior. 'There is psychic heredity as well as physical heredity. In spite of the fact that dog, horse, sheep, goat, cow, and pig have been domesticated since primitive neolithic times, they still betray tendencies and modes of behavior which belong peculiarly to their feral state. Dr. Lon is Robinson has written a charming book on the wild traits of the domesticated animals, which man has tamed but not completely transformed.

The dog before he lies down to sleep, it may be on a parlor carpet, turns about in an idiotic circle, as though he were still a Miocene wolf and had to trample down a bed of grass and weeds. The western horse bucks, shakes and puts down his head as though the saddle on his back were really a clutching panther and had to be shaken off. The cow secretes her newborn calf in the tall growth of meadow, as though she were still living in the age of fear. The independence, sure-footedness, cantion, obstinacy, and unshakable nerves of the donkey and goat date back to an ancient, self-reliant life in the mountains. 'The angry ewe stamps her feet when approached by a dog, who looks much like a wolf to her, and this is " a remunt of an old killing activity." 
The greediness, grunt, squeal, keen scent, and expert snakedestruction powers of the pig are reminiscent of the gregarious wild-boar days in the lowlands.

There are decided differences in the mentality and attitudes of $\log$ and cat. The tribe of tigers belongs to the solitary animals who depend for survival upon individual cunning, ferocity, and prowess. Inasmuch as the house cat traces her lineage to the tiger family, Robinson has boldly asserted that she lacks the capacities for companionship so well developed in the dog, who for centuries lived the social life of the pack and there learned the rudiments of helpfulness, loyalty, and sensitiveness. 'The cat, to be sure, loves to rub against you, and to nestle in your arms, which serve for a snug crotch. But perhaps she regards you in her dim way as nothing but a specially comfortable peripatetic tree. The dog, however, regards the household as he did the old wolf pack, and the master as the benevolent leader of the pack ; hence all the faithfulness, sympathy, and affection which have made him the favorite of pets. A dog cannot help but be cynomorphic in his mentality and attitude. To interpret even his comparatively simple psychology we must take account of the past, for the wild survives in the tame and the past in the present.

Can it be otherwise with the child? Childhood is something more than a simple, undifferentiated period of plasticity or imperfection. If the modern facts of heredity point to anything, it is that childhood is charged with the propensities of the past. And these propensities all have a history and significance, which the following survey of the human instincts will try to suggest.

Instincts are inborn propensities or modes of behavior common to the species. They are as innate and characteristic as peculiarities of structure. They belong to the creature 
as much as his claws or his snout, and are as essential for his survival ; for structure and function are inseparable, and instincts furnish the impulses which impel the creature to use his organs for self and species perpetuation.

There is no sudden or dramatic appearance of instinct in the animal kingdom, no satisfactory theory of the method of its origin. Even plants have definite modes of behavior in the presence of light, gravity, moisture, etc., called tropisms. These very elementary adjustments with reference to stimuli are essentially physicochemical in nature, aceording to Loeb, who thinks that tropisms explain many reactions in animals as well as in plants. These tropisms, or their equivalent, stand for a type of behavior more primitive than instinct. With the evolution of a nervous system definite instincts associated with distinct cravings finally are differentiated to displace, or possibly supplement, the tropisms. At first the instincts are simple, few, and intermittent. With advance in the animal scale they multiply, and man has a larger complement than any of his forebears, for the simple reason that he cannot escape his accumulated inheritance. A rough classification of his many instincts distributes them into four or five groups.

I. The self-preservative instincts. Self-preservation is the first law of nature, and the most fundamental instincts are those which most directly enforce this law. Hunger and thirst and the pant for breath are the deepest of all cravings, but they are not the sole expression of the primordial food quest. Out of the securing and defending of food supplies grew a more generalized desire to have and to hold, now called the proprietary instinct. This is one of the most protean impulses, and colors in ways innumerable both child and adult behavior. It would almost seem that instinct, like matter, is imperishable, and that man retains all the past 
momentum of this impulse to gain something, assimilate it, and make it his own. This instinct used to go out to food alone; now it goes out to all sorts of things, material and immaterial.

A special form of the proprietary instinct is hoarding, and closely related to this is collecting, an instinct which seizes upon almost every boy or girl, and never altogether dies out. It begins before the kindergarten age with the collection of knickknacks, stones, leaves, etc., and mounts high about the age of ten. The interest in collection burns so strong and is often so spontaneous that it can only be accounted for by an intensity enjoyed in earlier racial development. Hunting and migrating, both in animals and in primitive man, are obviously associated with the feeding instinct. 'To this day truancy seems to vary with the nutrition of the body, and with the season of the year. And the peculiar zest with which a boy uses a bow and arrow, gun or fishing rod, the consuming interest with which he stalks his prey, suggest the survival of ancestral life values.

Locomotion is as fundamental as feeding itself, and, of course, closely related to it. The manner in which the powers of locomotion develop in the child strongly indicates that the race did not always walk erect. The newborn babe can clasp a stick with strength enough in hands and arms to suspend its whole weight for several moments. In arboreal life a babe must cling to the climbing mother. Hands and arms, therefore, precede the development of the legs. All hand-grasping is at first clumsy, but in about three months a baby can oppose the thumb to the finger, a power which, by the way, the race did not always have. Before the end of the first year the child usually shows instinctive right-handedness. There are distinguishable stages in the assumption of the erect posture. First the head is held up; 
then when the appropriate nerve centers ripen, the baby insists on sitting up. Next he rolls or hitches, humps, crawls or creeps. Climbing also appears before he walks. This uncontrollable tendency to climb, Miss Amy Tanner regards as "a genuine instinct dating back to the time when men lived chiefly in trees, when strength of arm and grasp were essential to life." She thinks that direct harm must come from undue repression of this instinct.

But life, even with the lower animals, is more than a matter of food supply. There are dangerous things and fellow creatures to avoid or overcome. Out of these dangers spring fear and fight. The fearing instincts are perhaps the more primitive, for it is easier to avoid than to overcome. Recall the untold centuries in which man lived in insecurity, and it is easy to understand why a considerable and often extreme capacity of fear should survive in child. hood. Any strange, sudden, or overpowering object inspires the sense of lielplessness, dread, or terror, and mildly or profoundly disturbs circulation, breathing, and gland secretion. Trembling, pallor, fleeing, crouching, hiding, and cold sweat are natural reactions at least partially explainable on an evolutionary basis. Many fears are, of course, acquired, but often specific fears, such as the fear of large eyes, of fur, and of big teeth, come so early in babyhood as to seem purely inborn. Statistics show that the most numerous children's fears are of thunder and lightning, strange persons, beasts, the weather, and the elements. Bashfulness is an extremely interesting manifestation of fear. All children have some general fund of inherited timidity, dread, cantion, and awe worth observing and educating.

The typical preyed-upon fauna have chiefly fear in their composition. It is in their powerful and ferocious enemies that the pugnacious instincts are pronounced. But the 
history of anger is ancient. Animals so zoölogically old as the fish and the frog will show fight. An absolutely angerless normal child is inconceivable. Even deficient children, in whom so many instincts and capacities are lacking, frequently retain a great deal of temper, because anger is so deep-seated in the race. The instinctive expressions and special manifestations of fighting, such as gnashing, jaw tension, fist clenching, stamping, striking, teasing, bullying, and cruelty, point to its ancient association with the preservation of self and the destruction of others. But since in man we do not expect instincts always to survive in their original drastic brutality, we may look for the fight instinct in such temperamental characteristics as self-assertion, domination, executiveness, forcefulness, etc. Some children seem to have more fear than fight in their natures. Many of their traits depend upon hereditary endowment in kind and degree of instincts. Character is not only a bundle of habits but also a bundle of instincts.

II. The Mating and Parental Tnstincts. The second group of instincts comprises those which cluster about the production of offspring to perpetuate the species, which is of more concern to nature than the preservation of the individual. Deeply implanted, therefore, are the instincts of mating, and in higher animals special instincts of courtship, coyness, and sexual jealousy.

Jane Addams, in discussing The Quest for Adventure, gives candid recognition to these instinctive factors in human conduct. Speaking of the two elemental appetites behind "the activities of primitive man and his uncivilized successors," she says: "The first drove him to the search for food, the hunt developing into war with neighboring tribes, and finally broadening into barter and modern commerce; the second urged him to secure and protect a mate, developing 
into domestic life, widening into the building of homes and cities, into the cultivation of the arts and a care for beauty."

This fine statement shows how the so-called lower and blind instincts may be transmuted into higher attitudes and sentiments. There never can be absolute repression; it is always a problem of expression, for the old instincts are the raw material of all energy. The healthy sexual development of the young, both in its physiological and psychological phases, is coming to be of more critical and frank concern with sociologists and educators. Primary schoolteachers should appreciate that the problem begins before the period of adolescence.

In this sphere, behavior rises above the plane of brute egoism. The germ of all love can be sought in the rude and transitory impulses which bring offspring into the world and protect them in their helplessness. With ascent in the animal scale, the period of infant helplessness increases and parental sympatly is correspondingly prolonged and deepened. Homes are built to shelter the family; jealous rage flares up in the protecting parent, and in the lick, nestle, and caress are hidden tenderness. Indeed, the taproot of our moral sentiment has been traced to parental sympathy. Here also is the germ of altruism, which in the human extends beyond the narrow limits of the family, and may embrace the whole community. In social reformers and the great teachers it sometimes extends to distant and foreign peoples, to the whole world, and even to generations unborn. Doll play and the rearing and caring for pets constitute a childish fore-expression of the parental instinct. From this instinct teaching and other social welfare work get much of their motivation.

III. The social instincts. Even in the world of the lower animals the individual and the family are not all. There 
are larger social groups, - the flock, swarm, pack, the herd. If man is preëminently a social animal, it is because he has been preceded by a long line of gregarious ancestors. Gregariousness, or herding, is probably the most fundamental of the social instincts, for it is this which keeps the groups cohesive, gives the individual a dim consciousness of kind, and causes him to suffer a sort of nostalgia when detachecl. Galton has given us a brilliant description of the sociability of the South African ox: "When separated from his herd, he exhibits every sign of mental agony, and . . . he becomes a prey to the extremest terror. He strives with all his might and main to get back, and when he succeeds he plunges into the middle, to bathe his whole body with the comfort of closest companionship." In children we should call it cuddling up.

But simple gregarionsness does not insure a Utopian commonwealth. With animals, as with men, group life favors a new kind of social selfishness and self-assertion. Instincts of rivalry, deception, showing off, and jealousy arose under competitive conditions in animal communities, and were much accentuated by the social institutions of both barbarous and civilized man. Extreme self-aggrandizement, however, would destroy the very existence of the social groups, and so, in innumerable ways, counterbalancing instincts of sympathy and coöperation arose beside the aggressive traits. Kropotkin has filled a whole volume with examples in proof of his thesis that "mutual aid is a factor in evolution on a par with mutual struggle." These mutual aid instincts were so early developed that communistic ownership, according to Letourneau, prevailed among primitive people. School and society are trying to favor the expression of these instincts of mutual aid, which came late in racial history and need encouragement. 
Social life favors language. Expressiveness, both in gestures and cries, varies with sociability. Animals possess the rudiments of language in common with man, - the reflex cries of emotion, the rude interjections of fear, rage, alarm, the grunts of disgust, etc. With the higher mammals and apes the vocabulary of these language-cries numbers scores and even hundreds. Haeckel thinks that there was anciently a Homo alalus; but even this most primitive man, who preceded Homo sapiens, must have had the gesture and interjectional language from which articulate speech finally emerged. The mobility of lips, tongue, and laryngeal muscles, and, perhaps, right-handedness, favored increasing subtlety in articulation, which did more than anything else to raise man above his pristine compeers.

Underlying the instincts of mutual aid is the instinct of docility, the natural tendency to obey leaders and the example of others. This is a very broad trait in human nature, almost indistinguishable in its rudimentary form from passive plasticity or habituation. But it has an active expression as denoted by the word "obedience." This obedience is at first reflex, and as mechanical as the followinginstinct in sheep. But in man the instincts do not preserve their primal simplicity; they become overlaid with other instincts, and with ideas, concepts, and ideals. This primitive obedience is transformed by love and fear into all grades and manners of reverence and awe, - hero worship, God and nature worship, respect for law, and many special attitudes toward the beantiful, the scientific, and the good, which, if not instincts, are in origin instinctive.

IV. Play instincts. The above instincts, comprehensive as the list is, only partially account for the impulses of human conduct, and do not explain its development and many-sided adaptiveness. 'There is a very important group of instincts 
(if the term is to be preserved) which are fundamentally developmental and "adaptive" in character, — instincts so generic that they underlie, overlay, modify, inhibit, rehearse, extend, eonserve, and exercise the other instincts. These are the instinct-tendencies of self-activity and relaxation.

Play is the generic instinct of spontaneous self-activity. Froebel appreciated play. The plays of childhood, he said, "spring from inner impulse and necessity," and are "the germinal leaves of all later life." Schiller and Spencer speak of play as the expression of surplus energy. Groos, not content with this limited conception, and feeling the significance of Darwin's work on instincts, made a very extended study of play in man and animals. He concluded that play is not merely an outlet for superabundant energy, but is nature's method of preparing the young for the serious occupations of maturity. In play the inherited impulses and powers are exercised, trained, prepared. Play is anticipatory. G. Stanley Hall believes, on the other hand, that the key to all play activities lies in the past and not in the future. Play for him is reminiscent, _ " the motor habits and spirit of the race persisting in the present." Play is so protean that all these views are in a measure true. As Russel has neatly said, "Play is at once reminiscent and anticipatory, a welding of the future and the past."

The sphere of play is so intricately complex that it mocks precise formulations. Some plays do seem to be chiefly the outlets for obstructed or overflowing energy. Such are many of the random, sprawling movements of the well-fed baby, also rolling, kicking, jumping, romping, and " the immodest runnings and horrid shoutings" referred to by a medieval university. Joyous laughter also falls here. These plays, for want of a better term, may be called the "plays of exuberance." A common characteristic is that they tingle with 
the feeling of well-being, euphoria, and tend to be repetitive and rhythmical, as in laughter and skipping and dancing. Rhythm lies very near to play.

Closely related is that play which is chiefly for psychomotor exercise, like sliding, teetering, dragging, lustling, tossing, balancing, tumbling, rocking, and much of the persistent play with the senses and motor apparatus. In these plays it seems to be nature's main intent to train the powers of perception and movement.

Another group of plays and many games are more particularly recapitulatory in character, definitely suggestive of prehuman and prehistoric activities. Such are the plays of hiding, daring, fighting, hurling, lunting; of strategy, climbing, chasing, shooting, collecting, hoarding, exploring, camping, caring for flowers, plants, and pets; also the absorbing interest in the heroic and stirring stories of combat, fear, and cunning. In these plays and interests we feel most fully and intensely ancestral joys, and G. Stanley Hall thinks that "the pleasure is always exactly proportional to the directness and force of the current of heredity."

Imitation is bound up with play. It has been said that the child cannot live life, so he must play it. Here the word "play" is used almost synonymously with "dramatic imitation." A vast amount of play tends to be imitative; and this is one of the best arguments for Groos's contention that play is the means of preparing for future serious activity. For the dramatic and imitative plays of children surely initiate them into the situations and problems of adult life: doll play initiates into domestic life, playing store into commercial, playing war into military, etc. The dramatic tendency of play can be used by the teacher not only to bring the child into a consciousness of his future problems, but also into an appreciation of literature and history. 
The most extensive, pervasive, and fundamental type of play is workmanship. Since precise classification is almost hopeless in the field of play, "workmanship" may well be used as a blanket term to cover all those aggressive impulses which spring from a spontaneous desire to transform physical things or mental content, - in a word, all self-prompted attention and doing which have for their object the pleasure of a new achievement, a new experience. Workmanship, therefore, includes practically all experimentation, manipulation, constructiveness, destructiveness, and, on the more purely mental side, playful imagination, daydreaming, and curiosity. Curiosity has been well called the play of the attention. Much that seems old and easy to us is virgin to the child, and a large part of his play has a pioneering, exploiting character. Typical expressions of workmanship play are the productive and receptive experimentation with the senses mentioned by Groos, and all forms of manipulation like building with blocks, shoving and hustling things about, mussing paper, digging in the sand, molding mud, tearing things and knocking them down, spontaneous drawing, etc. The list is really interminable.

When the materials of life cease to be blocks and sand piles, when all childish play is outgrown, workmanship may still exert its force, giving figurativeness and humor to language, little tonches of adventure and originality to the daily behavior, and now and then true creativeness to thought and deeds. Workmanship is at the base of all adult originality, and the chief factor of artistic production. There is an element of constructiveness and creativeness in all workmanship, while the other distinguishable forms of play are reminiscent, rhythmical, or imitative, - the outlets for exuberance or the means of exercise. Workmanship clearly corresponds to that sphere of behavior which Royce 
calls initiative. Veblen speaks of it as "the ubiquitous impulse to do the next thing," - not the same thing, but something new.

It is tempting to exalt workmanship to the plane of a creative force in nature. Without it man surely could not have risen to his present position, and it is the impulse which makes for growth in the individual. The happiness and the originality of any person, whether child or adult, depend very much upon the full expression of this generic play instinct. Artists well fed and well loused, who are free to project all that surges within, are of all people the most enviable. The great tragedy of school and society is the suffocation of the creative instinct of workmanship) by a formal and thwarting environment. The problem of pedagogy and politics is to so reshape life that all the latent sprightliness, plasticity, geniality, and creativeness of children and of men and women will come to their fullness.

One of the chapters of Helen Key's famous book, "The Century of the Child," is entitled The Soul Murder of the Schools. Most of the repressiveness of the workmanship instinct which amounts to soul murder comes from a great undefinable, uncombatable fog, which will not dissipate until there is something like a regeneration and rejuvenation of the whole schoolroom atmosphere. 'Two of the most tangible enemies of workmanship which can be combated are habit and imperfect health.

Habit has been amply praised, but insufficiently depreciated. However necessary and beneficial, habit is a double-edged sword. It makes for mechanism, routine, delimitation, archaism. It compels the traveler of life to take only familiar, automatic journeys, and puts an end to all pioneering and discovery. Habit tends to destroy the very plasticity which gave it birth. With the encroachment 
of routine's prison walls, the deeper, older voices of the play spirit fade away, and childhood with its buoyancy becomes something to fondly and sadly gaze back upon; or, in the most pathetic eases, habit becomes such a tyrannical master of life that the vivacity of youth when seen in another is actually painful.

The other foe of workmanship is undervitality, insuffieient health. Workmanship has been called a tendency to display energy. Plants are sessile organisms, which do not bestir themselves; but in the amoba we find something akin to workmanship, - a fund of self-activity which varies with the amount of food and rest. With the evolution of the nervous system this available fund of energy tends to increase. One of the most marked and important traits in Peter - to recall our monkey with a mind - is his ceaseless activity, his tireless experimentation. Before the psychological clinic he behaved like an irrepressible, obstreperous boy. Primitive man had this same trait, but probably to a lower degree than modern man ; for there are good reasons for believing that in the race the instinct of workmanship has been increasing with those changes in mode of life, like the adoption of cooking, which result in the storing up of energy beyond the lowest need of existence. One of the important factors in the evolution of man undoubtedly has been the character of his meals, their frequency, bulk, and food values. Workmanship varies with degrees of neural nutrition. When energy is at a low tide, play does not necessarily cease, but tends to express itself along beaten and nonproductive lines. The favoring conditions for the free spirit of workmanship are good nutrition, rest, and the abundant energy of abounding health. The best, most wholesome, and creative things of the world burst forth from such accumulations of energy. It cannot be otherwise, 
for physical health is too closely identified with goodness, beauty, and insight.

V. Relaxation Reflexes. Nature has her own lawful limitations. All life oscillates rhythmically between two poles, - activity and rest. Workmanship represents the wave of energy at its crest; sleep is the hollow of the wave. Relaxation is as natural, if not as instinctive, as activity itself. We are accustomed to regard sleep as a kind of "temporary death," a negative and annulling affair ; but Claparède has recently well emphasized its positive aspects. He speaks of it as an innate tendency of inhibition, developed by natural selection. It is not merely a vegetative function, but a definite, positive mode of behavior, biological as well as plyysiological in import. Sleep has, of course, a deeply physiological, if not chemical, character; but so has hunger, and if we call one instinctive, why not the other? There has been no objection to calling hibemation in the lower animals instinct. There is also a very biological kind of human hibernation which goes on in the province of Pskov, Russia. The poor peasants are said to lie down in their beds with a bottle of water and a few loaves of bread, and to sleep and nibble till the coming of spring, when they rise to plow the softening soil once more. Our ordinary sleep is daily hibernation.

Sleep, therefore, has the following earmarks of instinct: it is a fixed, inborn, protective reaction, common to the species, and can be decidedly modified through the influence of habit. But whether instinct or not, relaxation is a generic form of adaptation not to be ignored in any survey of behavior. The positive and compensatory value of rest is only now coming to be recognized. Rest is not alone for recuperation; it is a protective type of adjustment. Our natural behavior has its basis in an intricate interrelated 
plexus of instincts. Some reënforce each other, but many have an antagonistic value. Thus curiosity may be considered an antidote of fear, jealousy of sympathy, and caution a counterpoise of competition. Sleep and other forms of relaxation, similarly, are compensating and counterbalancing adaptations to prevent the overexpression or disintegration of the assertive instincts. If anger and all the other instinctive responses were evolved through natural selection, it is easy to see how sleep grew up in the same manner. A quixotic fund of any instinet would be harmful. Workmanship without sleep would be ruinous.

Chamberlain has shown that primitive man and men of genius naturally, let us say instinctively, alternate periods of strenuous exertion with prolonged periods of lounging stupidity. It is just as innate to lounge as it is to strive, to relax as it is to exert. Inattention is as important and developmental as attention, assimilation as necessary as impression. Rest is the period of assimilation, and at the same time a safeguard against overexertion. The mastery of the fine art of life demands not only the nourishment of instinctive ambition, but the cultivation of rhythmical, adequate repose.

The enlightened teacher will, therefore, in a systematic manner, cultivate relaxation in her pupils. She will take a constructive and not a sensitive attitude toward inattention. Much of the school's inattention is attention to something else, but in young children there are many periods of reflex, instinctive brown study, in which the attention is diffused, dispersed, - momentary cat naps. These have a biological, lyygienic import, and ought to be cultivated rather than combated. If teachers had absolute sway over the attention of children, too many would become priggish little arlults. 'The German professor was three-fourths right, 
who said that the universal inattention of children is a natural safeguard against poor pedagogy. Good pedagogy would respect rest as much as activity. There should be rest periods as well as busy periods. Nature fills up many of the busy periods in the school with a pernicious dawdling and pretension of business, or a spreading it thin over a long period. If we were really interested in healthful activity, we should permit sheer idleness for one half of the busy period, and put a premium on getting the job honestly and vigorously done in the fraction of time left.

There is a peculiar form of inattention which frequently crops ont under the discipline of church, school, and supper table, - giggling. If we could dignify this unseemly conduct with the terminology of science, we should call it a psychophysical relaxation, adaptive in function, supervening in situations of stress, when the attention processes have been unduly tensed! Students describing their own giggling experiences said that these experiences werc especially liable to occur in an atmosphere of unnatural seriousness, or when tired mentally from protracted attention, or from much obedience to commands; when threatened with discipline, and when physically weary or nervous. Sometimes a superabundance of animal spirits favors giggling, but in any case it is a symptom of confused, tired, or obstructed attention, and is an organic method of relaxation and relief. Snickering, of course, is a very primitive form of humor, but the highest forms of laughter, and even philosophical humor, are grounded in a biological function such as has been suggested for giggling. A good laugh is a most effective form of relief. It removes unnatural tension. It breaks the semiparalytic grasp of sulkiness, flushes one's whole mental state, and restores a sense of values. Half. hysterical laughter and silliness often follow or accompany 
prolonged strains, such as sieges, earthquakes, court trials, domestic grief, and even continued intellectual effort. Such humor surely is the avenue of relief.

Sometimes the situation is so provokingly funny that we roll on the ground with sheer laughter, or we laugh until we cry. Indeed, crying and laughter are psychological and biological cousins. Crying, like laughing, is a drastic mode of relief, and there is universal testimony for its relaxing, even balming results. Medical men accordingly recommend it as having therapeutic value.

Crying, like its relative, follows upon a surcharged condition of the nerves, or of mental tension, whether in anger, grief, or joy. Borqvist, in his acute study of the subject, reports the case of a person who said, "Often when I am tired I have cried over things that when I am well I will langh at." This confession betrays the close relation between the two reactions; but Borqvist believes that there is this important and fundanental difference: "that laughing is the accompaniment of movements that promote digestion, and that crying is a part of the process which is involved in the act of rejection of food." Hence many of the symptoms of crying - such as the lump in the throat and the sobbing spasms of the diaphragm - suggest giving up in a digestive as well as a psychic sense. The conclusion is that "crying, in its last analysis, is a situation in which there has been strong effort and depleted nervous energy. It is essentially a breakdown, in the nature of a cessation of adaptation to envirommental conditions." But this very cessation of adaptation is itself an adaptation.

Crying, laughter, silliness, whining, giggling, peevishness, sulkiness, sullenness, inattention, and obstinacy are all related phenomena which ignorant common sense will often treat in an arbitrary and unjust manner. What we need is 
the biological and physician's insight to interpret them in terms of their connection with nature's inexorable demands for relaxation and relief.

Obstinacy, like crying, is an adaptive cessation of adaptation. It is, of course, a highly variable complex, but typically it is an inlibitory instinct comparable to other forms of protective inaction, like the vacant mood, lounging, and even sleep. 'Theodate Smith, who has instructively described the psychology of obstinacy, says that the "one symptom invariably present in all cases appears to be a deficiency of muscular control, either in the form of cramp or temporary paralysis." This statement strongly implies that obstinacy has a positive protective value.

Why not regard it as an instinctive antidote for docility, which is itself instinctive? Obstinacy is present in animals in the form of balkiness, which has its "psychic roots in the thwarting of instinctive desires, in physical conditions and overfatigue of the nerve centers." These are the very stimuli which produce all forms of inattention, laziness, and sleep. Obstinacy, like other instincts, is aggravated by humidity and other weather influences. It is characterized by rigidity, blankness of expression, inertness, limpness, and other symptoms of "a dead-weight type of opposition." 'The impossibility of coddling or beating obstinacy away and its response to the letting-alone treatment eloquently suggest its instinctive and remedial character. It is always part of a complex, and has a compensatory or counterpoise significance. It is associated with the spirit of independence characteristic of solitary, self-reliant animals like the donkey; it appears frequently in feeble-minded children who have scant power of attention and therefore would be likely to balk often ; and again, it is common in children of spirit, boys and girls with the rebel in them. Nature always means to keep 
a balance, and the existence of institutional obstinacy is a hopeful sign that she has not given even the wards of prisons, schools, and asylums a ruinous proportion of docility.

VI. Work. There is a kind of stubbornness which stands for persistence in a purpose or cause, and this kind should be sharply differentiated from inhibitory obstinacy. 'This persistency really is an expression of the instinct of work rather than of relaxation. Throughout a venerable prehistory man was schooled in the lesson of diligence. In most primitive times his impulses of workmanship resulted in merely desultory activity, but with the schooling of centuries this activity became more and more consecutive and purposive. Workmanship alone camnot account for man's progress. Upon this instinct was built another which may be called the instinct of perseverance, — not only doing something, but persisting until the thing is done.

There can be no doubt that this instinct of perseverance, or consecutiveness, has been accumulating; that it was much greater at the close of the paleolithic period than during the eolithic, and that in the metal ages it was stronger still. In this instinctive persistence we must look for the root of all the heroic labor of man and his patient vigils, of all his ambition, strenuousness, and the terrific pace of modem life, the sedulousness and the application which the schools have been nourishing for centuries. Workmanship and perseverance are to each other like play and work.

The legion of instincts which we have reviewed represent the deepest requirements and tendencies of the race, traits so fundamental that they are transmitted from generation to generation, ingrained in the very structure of the nervous system. Most of these traits are geologic in their venerability. Childhood play, which involves so many instincts, is like a processional in which the prehuman and 
human past reappears with the ripening of successive nerve centers. Nothing, therefore, reflects so well as spontaneous play the child's interests, if by that term we mean his own requirements and tendencies. The evolution of behavior in the race cannot be explained by intellectual progress. All development, both in the child and in the race, is grounded in instinct. The pedagogical principle based on this conception is stated in unequivocal words by Dr. Dewey: "The primary root of all educational activity is in the instinctive, impulsive attitudes of the child, and not in the presentation and application of external material." The teacher who ignores this principle must hear the parable of the house built on the sands.

All happiness and health depend, both in childhood and maturity, upon the adequate expression of instincts. There is hardly an instinct which must be absolutely repressed. Perfection and poise are the fruit not of suppression, but of a proper harmonizing of all the instincts. The problem of pedagogy is to give each instinct the fling it needs in childhood; the problem of the larger hygiene is to strike the proper balance between the instincts of activity and relaxation. Dr. Burnham has stated the aim of education to be the development of habits of healthful activity. No activity can be ideally healthful which does not have a maximum efficiency, and it cannot have this maximum unless it is generously offset by leisure. Here curriculums and life make their greatest errors. It is high time that the schools should appreciate the existence and worth of the benevolent, conserving instincts of leisure. To use a Hibernicism, leisure must itself be considered a healthful form of activity. Application does not need to be reënforced so much as counterpoised. We must learn and teach the art of leisure. Real growth and sanity demand relaxation in all its degrees, - 
slumber, cat nap, lounge, loaf, and listlessness. It cannot be doubted that the hygienic distribution of periods of rest and activity would enormously increase the sweetness and productiveness of mankind. Poets have vied with each other in their praises of sleep, the "sweet restorer." Science is indorsing their sonnets. Sleep is indeed the "dear mother of fresh thought and joyous health."

This is the gospel of relaxation, and if it is biologically true, schools should obey it and build upon the instincts of relaxation habits of healthful rest. 


\section{CHAPTER VII}

\section{THE HAND OF THE RACE AND OF THE CHILD}

Abont seventy-five years ago, when the Bridgewater Treatises were being written to prove the power, wisdom, and goodness of God as manifested in creation, Sir Charles Bell, in speaking of the human hand, said : "It presents the last and best proof in the order of creation of that principle of adaptation which evinces design. It is the consummation of all perfection." Anaxagoras entertained the opinion that the superiority of man was owing to his hand, but with this view the reverent Sir Charles Bell takes issue. "We rather say, with Gàlen, that man has hands given to him because he is the wisest of creatures, than to ascribe his superiority and knowledge to the use of his hands." Dr. Robert MacDougall, writing from the modern genetic standpoint, says: ". . of all bodily members the hand is the most human and the most noble. In its features and capabilities is symbolized all that man has achieved in his long upward march from the primeval ooze."

The early worm dwellers in this ooze possessed not even the rudiment of a hand, but the primitive fish who descended from them in all probability had a pair of fin folds extencling laterally from head to tail in the form of continuous pleats in the skin. These skin folds were the forerunners of separate pairs of pectoral and pelvic fins, variously provided with cartilaginous rays, horny fibers, and bony rods. And these single-jointed paddles in turn were the forerunners of the many-jointed systems of levers of the later 
quadrupeds. The large faet of descent is admitted, but the details of the transformation are not known. "We do not know," says Wiedersheim in his "Comparative Anatomy," "how the pentadactyl limb of an air-breathing vertebrate, adapted for progression upon land, has been derived from the fin only fitted for use in the water, and paleontology has so far furnished no solution to this problem." The significant fact is that the fore limbs and hind limbs of all vertebrates above the fishes conform to a single ground type.

The hand of the race is the terminal organ of the fore limb. Typically, it consists of a group of wrist and palmar bones attached to the radius and ulna, and five digits. Even in the amphibia the basal plan of the hand is highly analogous to that of the human. But the amphibian hand is webbed and adapted only to the humblest uses. In the reptiles the hand remains limited chiefly to the function of locomotion, though in the prehistoric pterosauria the fifth finger was elongated and supported a winglike attachment for flying. In most snakes the extremities have practieally vanished. In birds the fore limbs are transformed, but not beyond recognition, for the digits and sometimes even the claws persist in the wings, as in the archæopteryx and a few existing species.

In mammals the anterior extremity comes to serve almost every possible use. In the whale the digits form the frame of a finlike paddle. "Place drawings of the skeleton of the human hand and the fin of a whale side by side and ordinary observers will require the printed names underneath to distinguish them." In the bat the digits are produced into long supports for a winged membrane for flying. In the horse the third digit is specialized into a hard, rigid hoof for swift running. The paleontological ancestor of the horse, a little plantigrade ereature about 
the size of a fox, had a complete set of digits, two of which were to disappear, the other two becoming much reduced before Quaternary times. Incidentally it is interesting to know that the embryo of the horse during its development passes through all these phylogenetic stages. In the burrowing mammals, like the mole, the fore limbs are specialized for digging; in the arboreal mammals, for grasping

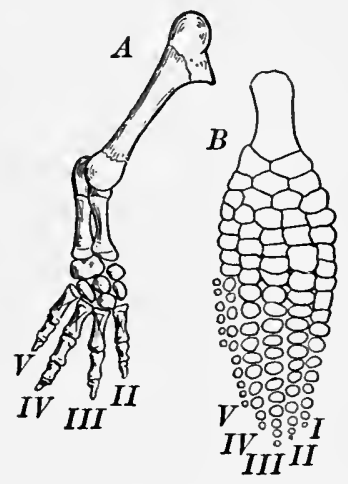

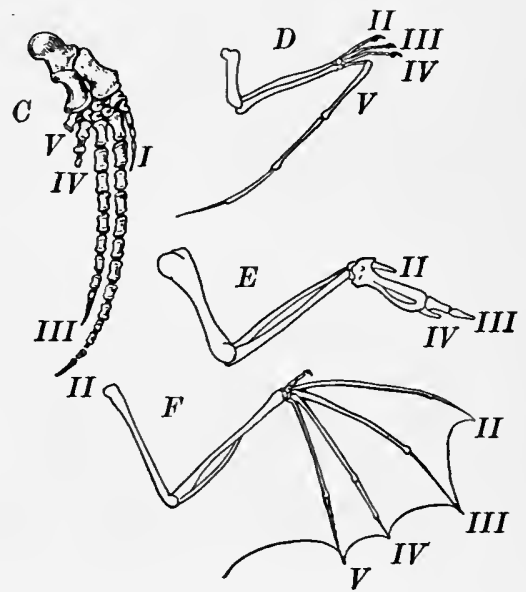

Fig. 16. Modifications of the Fore Limbs (for Crawling, Swinuixg, axd Flight)

$A$, primitive salamander (Yecturus) ; $B$, extinct marine lizard (Ichthyosau$r u s) ; C$, dolphin; $D$, extinct flying reptile $($ Pterodactyl); $E$, bird; $\boldsymbol{F}$, bat.

(From Wilder's "History of the Human Body")

and climbing. Even in the climbing marsupials the bones of the forearm, which lower in the animal scale are firmly connected, become articulated, enabling the rotating movements of supination and pronation, so highly developed in the human forearm.

Other modifications which have been pointed out as necessary for the perfection of the hand are the denudation of the hair, the increased sensitiveness of the palms and fingers, 
and the elimination of the claw. In the lemurs the claws are almost absent, and in the monkeys they have all been replaced by nails.

But the feature of most decisive significance in the anatomical evolution of the hand is muscular. 'The most primitive racial hand was capable of nothing more than simple, simultaneous, oscillatory movements, and the only muscles were elevators and depressors. Ascending the scale, these muscles become more and more differentiated and complicated ; protractors, retractors, flexors, extensors, rotators, supinators, pronators, abductors, and adductors appear to enlarge the repertoire of movement. The human hand is now equipped with over two dozen beautifully adlapted muscles. 'There has been, of course, a corresponding growth in nerve supply, with the addition of higher accessory nerve centers to the ancient fundamental ones. Innumerable nerve filaments now bind the hand to the brain.

We have alrearly seen, in the chapter on the biological perspective, something of the significance of the muscular system. The nervous system is, after all, only a part of a larger unit, the neuromuscular system; and its development from the sea anemone, through worm, fish, reptile, and mammal, is interlinked with the multiplication and perfection of muscles. The peripheral organs of sense and of movement are primary, and the development of the central neural masses like the brain is sympathetic with that of the periphery. It is this large fact which gives the hand its vital influence upon the development of both the race and the individual. MacDougall has gone so far as to say that "the specialization of the hand was the single indispensable condition, so far as regards gross anatomical features, which determined the widely divergent subsequent fortunes of the monkey tribe and man-ape respectively." 
A few years ago when the great Italian scientist Angelo Mosso came to this country, he delivered a very suggestive address on the relationship between psychic processes and muscular exercise. "The mutual relation of intelligence and movement," he said, " is one of the most constant factors in nature." The superiority of the Greeks, he thought, was due to their great attention to bodily exercise. Similarly, the genius of the great artists in the renaissance was developed by the exercise with which they gained their manual dexterity. Giotto was painter, sculptor, and architect; Michelangelo was anatomist, painter, sculptor; and Leonardo da Vinci, the champion ambidexter of the world, was musician, painter, engineer, architect, man of letters, sculptor, etc. "The more mobile the extremities of an animal are," says Mosso, "the more intelligent it is. Among all birds the parrot is the most intelligent because it makes more use than do other birds of its legs, beak, and tongue; the elephant is more intelligent than all other wild animals because he makes use not only of his legs, but also of his snout as organs of movement." What the trunk is to the elephant the hand is to man.

Dr. Burke, in his oft-quoted article on the development of the nervous system, said, "When we attempt to measure the gap between man and the lower animals in terms of power of movement, the wonder is no less great than when we use terms of mentality." Imagine the state of a creature in whom the hand is perpetually degraded to the office of locomotion. Such is the state of all hoofed animals and largely of rodents, insectivora, and carnivora. Even in the clutching, tearing, burrowing, and digging of the latter animals, as Burke pointed out, the real work is done by the more central muscles. The accompanying diagram of the hand of the mole, though it may imply sad havoc to the 
lawn, does not suggest a range of movement or motility large enough to place the animal high in the mental scale.

It is not until we reach the arboreal mammals that clumsy hoofs and paddy paws give way to flexible digits which approach the human hand in both appearance and function.
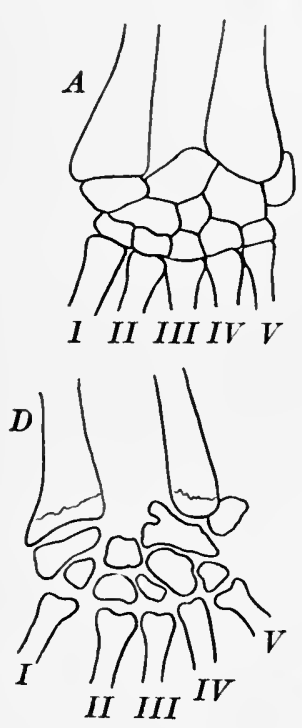
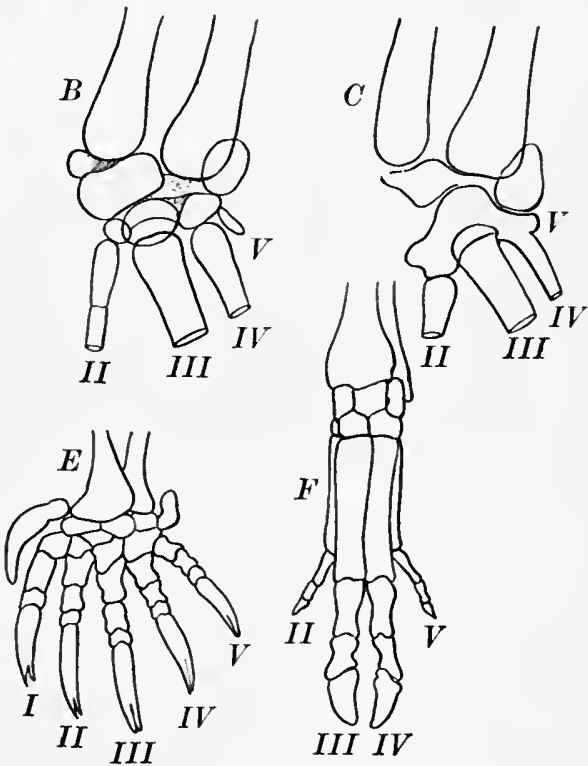

Fif. 17. Variocs Foris of Carpes (Wrist)

$A$, New Zealand lizard; $B$, chick embryo (early stage); $C$, chick embryo (later stage); $I$, European lizard; $E$, mole: $F$, pig. (From Wilder's "History of the Human Body")

Of course even here there are exceptions, such as the sloth. This uninspiring creature has hands and feet which are like double and triple hooks. With these he fixes himself to a bough, his chief hope of defense the livelong day being his resemblance to a motionless tuft of hanging moss. "A hungry bear collects a family of sloths as he would gather a bunch of grapes." But the typical tenant of the trees is 
a creature who is all hands, even to his feet and tail. For example, take the American opossum: he grasps the limbs with considerable dexterity, and with his prehensile tail or fifth hand he will even roll up a large bundle of leaves and carry them to his hole. The cleverness of the raccoon in the manipulation of his handlike claws also is characteristic and bespeaks a high degree of intelligence, such as Davis has found in his interesting study of that animal's behavior.

The most important differentiation which takes place with the arboreal needs of climbing, clinging, and grasping materials for food and home building is the greater mobility of the first digit. Even in the marsupials the great toe acquires the power of opposition to the other toes. In some species this power of opposition is limited to the foot, but with the apes it extends to the thumb. Man has lost his power of opposing the toe, but boasts the highest development of thumb opposition. It was when the arboreal life was supplemented by terrestrial habits, and when our primitive progenitors began to walk erect, that the hand was freed for a multitude of new uses, and experienced a new burst of development, linked with the largest destinies of the race; for the hands became the servants, the antenna, of the brain, and in a very real sense the creators of new areas in the brain.

In every important anatomical feature the hand was perfected with the higher uses to which it was impelled. It became softer, more slender, supple, and sensitive. The arc of rotation of the forearm became greater, so that now it is about one hundred eighty degrees. The wrist hinges became more flexible, and MacDougall thinks there has been an increasing relaxation of the system of muscles which bind the hand together. The thumb has become more independent and powerful, so that now it can grasp a sphere where once it could only grasp a cylinder, or still earlier moved 
parallel with the other digits. Each digit has gained a similar independence, both in flexion and in lateral and oblique extension, permitting now the most marvelous manipulations of instruments both of art and of utility.

The investigations of Feré seem to prove that there has been an increase in the length of the last joint of all the fingers. Undoubtedly there has been increase of sensitivity. The hairs and callous pads have been supplanted by a soft mosaic of tiny sensorial areas, so that now the most delicate contacts and minute distances between single contacts can be discriminated. In the palm of each hand there are some six hundred Pacinian corpuscles and fifteen thousand Meissner corpuscles, - microscopic spongy bulbs the chief organs of touch. There are thousands more in the fingers, which are fourfold more sensitive than the palms.

There is one other way in which the hands of the race were specialized, or perverted as the ambidexters would say. We know not when, but probably as far back as the eolithic age, the human species began to favor one hand, and there is some evidence from the paleolithic drawings that it was from the first the right hand. It is natural that such a specialization should have developed, for it is nature's way of increasing perfection. Davis states a fact about the raccoon which suggests the possibility of even prehuman unidextrality: "Through practice the animals soon acquire the ability to use each forepaw independently, and are finally able to use one paw with greater quickness and accuracy than they formerly used the two." A natural evolutionary step following upon this would seem to be the particular perfection of one hand.

What is the origin of right-handedness? There are all sorts of ingenious theories: (1) It is the result of the way the mother carries the child, giving the right hand the 
larger chance for development. (2) Primitive man shielded his heart, which is on the left side of the body, with his left hand, and fought with his strong right arm; tradition and education have emphasized the distinction. (3) The viscera on the right side of the body weigh one pound more than those on the left, the center of gravity is on the right side, and the kind of respiration which accompanies exercise of the limbs on the right is more favorable to sustained exertion than vice versa. The reason for right-handedness, then, is a mechanical one. (4) The directness of the communication of the carotid artery with the aorta and the larger caliber of the left carotid give the left hemisphere, which controls the right hand, a nutritional and therefore functional advantage. (5) Unidextrality is the result of ocular one-sidedness, which preëxisted and made necessary the paramount use of one or the other hand. (6) Righthandedness is a character which has been attained in the ordinary course of the evolution of man by the process of natural selection. Left-brainedness is as much the cause as the result of right-handedness.

It is unnecessary and impossible for us to go into a critical discussion of these theories. Jackson in his work on ambidexterity minimizes them. The most tenable general conclusion seems to be that right-handedness is a racial hereditary tendency, correlated with a structural and funetional preëminence of the left hemisphere. It has an organic basis, not necessarily in the gross weight of the left hemisphere, but in the innate predisposition and organization of the cortical neurons of that hemisphere. With most people, therefore, right-handedness is truly instinctive, depending upon inborn peculiarities of the racial brain. Lefthandedness, whether atavistic, pathologic, or sporadic in origin, tends likewise to be hereditary. 
Summarizing the chief stages in the evolution of the racial hand we find the following: (1) differentiation of the digits from a simple, single-jointed lever; (2) multiplication and segmentation of muscles and nerves, accompanied by the addition of accessory powers of grasping and manipulation grafted upon the fundamental powers of locomotion; (3) complete abandonment of hand locomotion with the assumption of the erect attitude; (4) opposition of the thumb; (5) right-handedness; (6) development of crafts and fine arts, mechanical and technical skill.

It will be interesting to see whether the development of the hand in the individual child reproduces these chief phyletic phases.

The earliest and most striking hand feat exhibited in infancy was demonstrated by Dr. Robinson in his experiments with Darwinism in the nursery. He found that even a newborn baby can grasp a bar or a finger, and suspend its weight from ten seconds to a minute. When the baby is two or three weeks old, it will remain hanging for as much as two minutes without any sign of strain. This marvelous reaction, which would tax even an adult, and which so contrasts with the infant's general helplessness, can only be explained on evolutionary grounds.

For months the hand movements are always simultaneous. The child camnot do different things at the same time with each hand. Many of these early finger and arm movements have a rhythmic, oscillatory character which to some observers is suggestive of the aquatic stage of race development. With the advent of cresping and climbing the hands return to their ancient function of locomotion and grasping. As we should expect, the fingers for a long time move parallel with each other. Any one who will watch carefully the manipulations of a three-year-old child will find that 
the power of independent flexion and extension of the digits is still considerably undeveloped, and that the tendency to use the fingers together in a single hook form persists.

The power of opposition in the phylum, as we saw, first appeared in the hind limbs; and the big toe of babies is

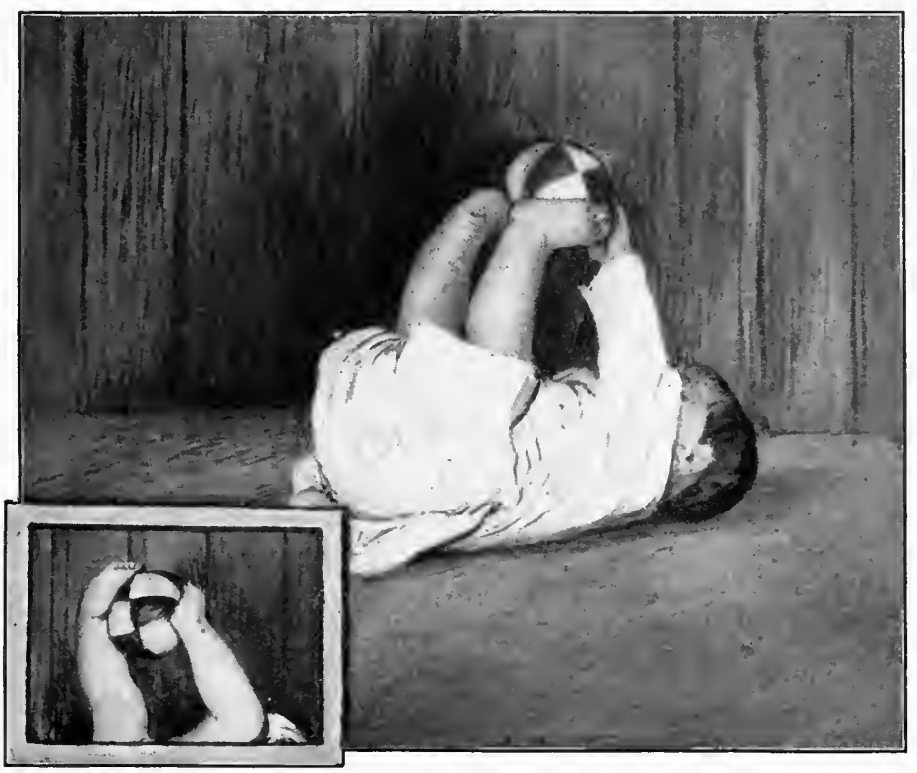

Fig. 18. The Feet as Hands

In infancy the foot exhibits some of its racial prehensile power

strangely mobile, as are the little toes, which can grasp with a vigor reminiscent of their ancient prehensile character. The accompanying photograph shows the instinctive skill of a seven-months-old baby in "handling" objects with the feet. The independence of the thumb asserts itself slowly. As Burke says, "For the first few months of life the thumb is really a nuisance to the child and is contimually in 
the way." After it has come out of its curled-up position in the grasp it takes over a half year or more before the method of opposition is well established. All the fingers move parallel and the palm faces downward. The invalid in extreme weakness reverts to a racially old method of prehension and grasps with all the fingers moving parallel and the palm facing downward. The normal developed grasp is of course with the palm upward and the thumb opposed.

Simultaneity is a characteristic of the early hand movements. Even the adult does not overeome completely this tendency of the hands to act in unison. Idiots never overcome it, and when one hand moves, the other must move sympathetically. But in every normal child this bilateral simultaneity begins to break up at about the eighth montl, when there is a propensity to use one hand more than the other. We have seen a baby in arms show very convineing evidence of this. We held her so she could strike a Chinese gong which hung from the ceiling. She did it with amusingly earnest pleasure. Repeatedly we put the little hammer with which she struck into her left hand. She would make a few efforts with that hand, and then, without fail, quickly transfer the hammer to her right hand, which even at her tender age she used with decidedly greater facility and effect. In Professor Baldwin's child a preference for the right hand began to manifest itself as early as the sixth month.

This unidextrality does not appear with equal intensity and at the same age with all children, nor does it develop at a uniform rate. In fact it may be - if we knew all the facts on this puzzling subject - that ambidextrous training should have a relatively larger place in early childhood, as it did in the earlier experience of the race. In most cases such training would have a favorable effect on symmetry 
of posture, would make for balance of movement, and relieve muscle and eyestrain. Besides, the power of the right hand would itself be improved by the exercise of the left. There is a kind of cross-education, as experiments in the laboratory have proved. It was shown with the mercury dynamometer that the unpracticed left hand gained in nine days about 50 per cent in strength of grip through practice of the right hand. It was also demonstrated in certain tapping tests that the unearned increment extended not only from hand to hand, but to various parts of the body, from hand to foot. The ease with which the left hand does mirror writing also suggests the fact of cross-education.

Christopher found, in his investigation of the Chicago public-school children, that a marked difference in the strength of the two hands does not appear in boys till after the fourteenth year, nor in girls till after the thirteenth. The disparity between the left and the right hand seems to be greater as a rule in bright children. If this is a law, it is one which the extreme ambidexter must respect; but there is still a place for a moderate ambidexterity which will favor the specialization of one hand, but will not deny it the advantages that come crosswise from education of the other, nor deny the whole body the benefits that come from bilateral control.

Right-handedness and speech bear both genetic and neurological relations to each other. Primitive language was that of the hand, and it is probable that the right hand was preëminent in gesturing. The neurons that control this hand are in the left hemisphere, and the many hand-motor associations which the perceptions and images of things awaken are predominantly represented in that hemisphere. When articulate speech arose, the delicate neuron organizations which govern it, both on the sensory and the motor 
side, naturally located themselves in the left hemisphere, and the highly complex art of writing words also probably has a special center there. In left-handed people these speech centers are in the right hemisphere.

That there is some sympathy and connection between the hand-motor areas and the speech areas is suggested by the fact that right-handedness and articulate speech occur at about the same time in little children. Sikorski, the authority on speech defects, found, after examining ten thousand pupils, that the proportion of left-handed writers is almost twice as great for boys as for girls. He also found by comparing the copy books of boys and girls that ataxic writing was from seven to eight times more prevalent with the former. He correlated these facts with the well-known truth that boys are about three times more susceptible to speech defects than girls. This is a neural susceptibility that may extend to the writing center, which seems to stand in close relation to that of speech. When marked left-handedness shows itself, the neural center of gravity apparently is in the right hemisphere, and systematic interference with left-handedness therefore works against the designs of nature, and may so disturb the neural equilibrium that speech defects will ensue. The fact that left-handedness is so often hereditary is itself significant. The suffering and harm, both mental and physical, which are being visited upon constitutionally left-handed children ought to come to an end.

The law of evolution in the hand of the individual seems, therefore, to be like that of the race, a gradual progression from simultaneity to independence of movement, - a law which applies first to the whole hand, and then to the separate digits, and later to the separate joints. Manual dexterity consists primarily in ability to execute distinct 
little movements, and only secondarily in the coördination of these. At first the baby camnot even put his hand to his mouth, and when he does attain to this power, one hand tends to move sympathetically with the other. Later, this same child may make literally hundreds of simultaneous, but different, digital movements with both hands. A trained person can, according to figures quoted by Jackson, play on the piano 5,595 notes in four minutes and three seconds.

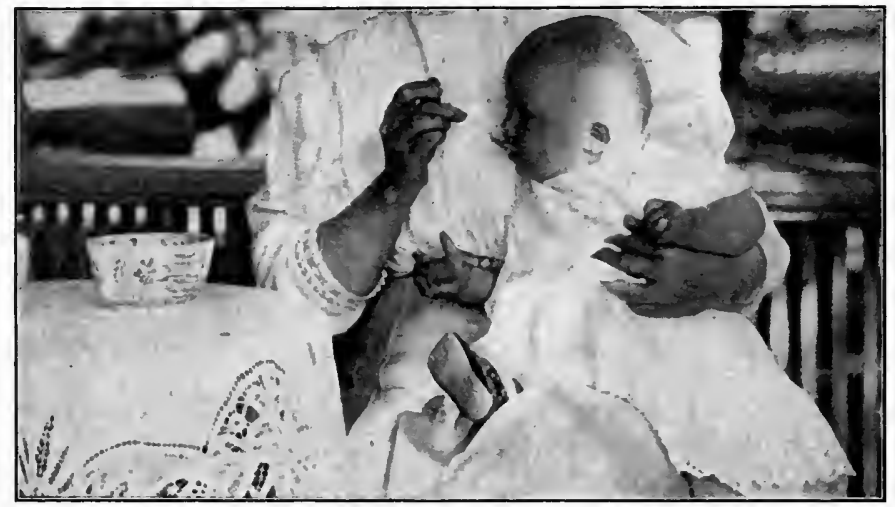

Fig. 19. Baby and Adult Hands

To get an adequate appreciation of the almost consummate perfection of the human hand, one has but to compare it with some of its ancestral forms and capacities in the lower animals, in infants, or in defectives in whom it has suffered arrested development. The accompanying picture illustrates, as beautifully as a nonkinetoscopic picture can, the salient differences between the controlled, coördinated adult hand and the undeveloped, half-anthropoid hand of the infant. See the tendency in the baby hands and arms, to say nothing about the feet and legs, to move all together. If the stockings were only off, we should see 
evidences of simultaneous flexion of toes as well as of fingers. Notice the padded, unrelaxed character of the baby hand, and how closely the fingers act and lie together. Contrast with this the separate control, in both flexion and extension, of the individual digits, typical of the adult's hand, when it is normally developed.

'The significance of the perfected human hand is still more forcibly brought out by a comparison with the idiot hand which was so well described by Séguin in his classic essay: "The hand of $R$ is small, the nails short and brittle, fingers as if unfinished, no power, no skill, only automatic movements mainly from the wrist. He could not put his fingers in any given attitude. He could not rotate on command that wrist so nimble when striking or vibrating automatically. He could obey the movements of eleva-

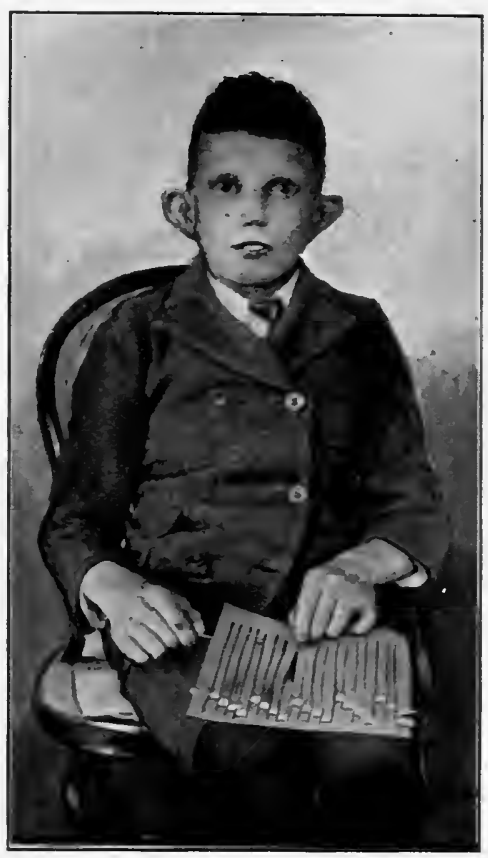

Fig. 20. The Haxds and Handwork of ax IMbecile Boy tion and abduction, but not always, nor with anything like precision."

Grasp this hand and the very feeling of it is at first uncanny because of the clammy skin, the unyielding, unresponsive fingers. Some of the most fruitful tests determining mental efficiency are those which demand the use 
of the hands in a controlled manner, as threading needles, tracing lines, striking dots with a small pointed wand, stringing beads, etc. Simple activities - such as buttoning and unbuttoning, tying shoe strings, scrubbing, peeling potatoes - often constitute the highest attainments of the idiot hand, even under education. One of the tests to which

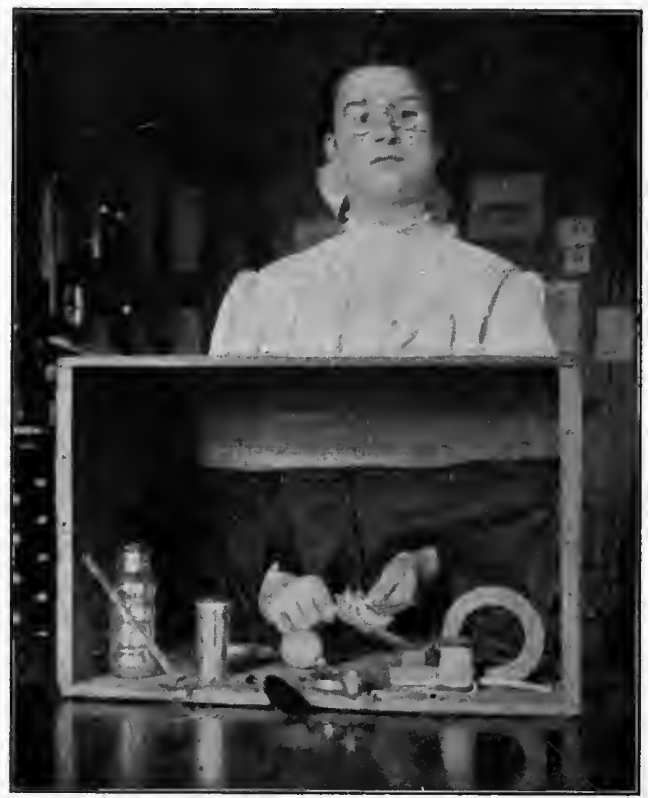

Fig. 21. Stereognosis these children - for so they always are, cven though they may live into mature age - are subjected in the Home for the Feeble-minded at Vineland, New Jersey, is called the stereognostic test. 'The subject puts his hands into an inclosed bag to see whether he can by stereognosis - that is, by feeling the objects in the bag - distinguish between the ball, brush, comb, key, etc.

It was by training the idiot hand that Séguin awakened the idiot mind. The hand, as we shall show in the following chapter, is truly an argan of perception. With its flexible motor equipment it explores surfaces and outlines, and through its thousands of microscopic touch corpuscles, 


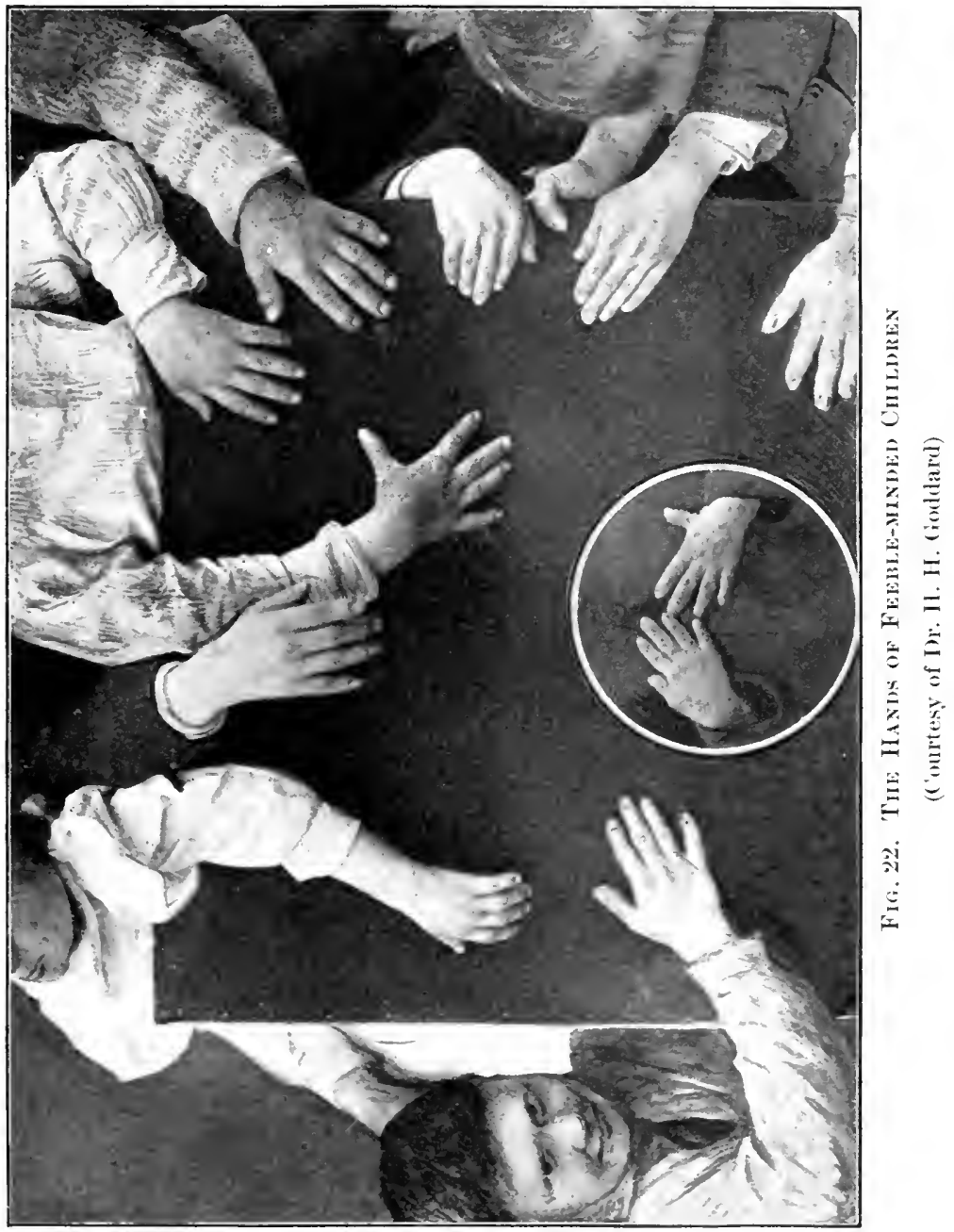


cutaneous and articular, it helps to frame a figured consciousness of the size, form, rondure, edges, etc., of things. At the end of the index finger there are twenty-one Meissner corpuscles to one square millimeter. The finger tip can distinguish scparate vibrations, even though they impinge at the rate of 1552 per second, can discern a minimal distance of one tenth of a millimeter, and a weight of three grams to a square millimeter. Furthermore, the internal sensory mechanism of the hand is so delicate that if the hand be moved through the tiniest fraction of an are, the movement will nevertheless be felt. Contrast all these powers with those of the brute paw!

But these refined sensory qualities are not to be considered as divorced from the incomparable motor mechanism of the hand. It is the motility of the hand, joined with its intrinsic sensitiveness, that makes it the supreme organ of perception. The rods and cones of the retina are not stereognostic. As MacDougall says, "The world becomes real to us only in so far as we are active in relation to it." Creatures with clumsy and callous limbs cannot get the varied tactual contact with the configuration of objects upon which clear perception depends. The exploring hand furnishes not only the passive tactual experiences, but the vivid, orderly kinæsthetic sensations which make it "a second visual sense by which the pathway of visual perception is illuminated." If teachers were only more profoundly convinced of the psychology of all this, they would not so exclusively address the eye and the ear.

It seems to us that teachers should become more conscious of the hands of their pupils. When the whole boy comes to school, he brings his hands with him, and though they may sometimes be dirty, that is not their most vital characteristic. We know one teacher who does appreciate 
hands. She often takes pupils by the hand; she judges their temperament by the clasp, and when she wishes to understand their passing mood, she feels the hand. By this "digital diagnosis" she learns more than she can in any other way. In fact, she has a half-conscious pedagogical palmistry which enables her to distinguish mischievous, sluggish, and nervous children by their hands. If she hesitates for a pupil's name, she looks at his hands and promptly the name comes back to her, so much individuality has the hand; and when she tries to recall a past schoolroom, an assemblage, not of faces but of hands, troops before her mind's eye.

Hands and face, - these are the two unclothed, unmasked parts of our physical personality through which character speaks. And Helen Keller writes: "Not only is the hand as easy to recognize as the face, but it reveals its secrets more openly and unconsciously. People control their countenances, but the hand is under no such restraint. It relaxes and becomes listless when the spirit is low and dejected; the muscles tighten when the mind is excited or the heart glad, and permanent qualities stand written on it all the time."

These qualities, both permanent and passing, deserve the teacher's attention. It is not a question of linear astrological palmistry, but of a recognition of the larger expressiveness of the hand. Dr. Warner, after examining some thousands of subjects, men, women, and children, found that " the different postures of the hand could be accepted as expressions of certain conditions of the individual, as physical signs or objective observable expressions inherent at the time." Thus there is the normal straight hand which is extended in a poised, balanced manner typical of strength. The nervous hand tends to bend, and the feeble hand to droop. This extension of the hand is a very good test of the child's general control and vitality. 
The teacher cannot go into the manicure business, nor will she try to make dandies, but the ideal of a clean, wellkept, healthy hand ought at least to be in mind. She should recognize the existence of unhygienic dirt. A physician, in a recent article, has gone so far as to assert that " the chief unintentional crime of our age, if we can call that which is unconscious and unintentional a crime, is dirty hands. Less than a century ago the medical profession had to face this condition in a serious form."

Surely the teacher should be interested enough in finger nails to detect the many cases of nail biting which are very numerous with girls at a critical physiological age. This habit often is a symptom of something larger than a little nervousness. But even so the hand is too precious to be disfigured by onychophagy.

There is another form of abuse to the hand whose unpleasantness we cannot cover with a scientific name, but the existence of which is likely to annoy teacher and parent. This is the perversity of sucking the thumb. It crops out in most unexpected places, often is a fetish for inducing sleep, and sometimes the very structure and flaccid appearance of the thumb betray its excessive indulgence. The palate may even be so deformed as to cause a lisp in speech. In many cases no amount of persuasion, bribe, or punishment is of avail. Even bitter aloes and asafetida applied to the thumb do not deter, and we know of one case which did not respond to treatment until an old-fashioned country doctor tied the arm to a shingle splint under the garment in such a way that it could not be flexed, and the thumb simply could not be brought to the mouth.

Is not the hand worthy of a little more conscious appreciation and respect? We fold the hands of death tenderly, and they affect us with a strange power, for when lifeless 
they suddenly suggest so much that we never thought of while they were living and acting; for those hands symbolize all the deeds and misdeeds of a life. One of the most impressive objects in the National Museum at Washington is a bronze cast of the strong and tender hand of Abraham Lincoln.

How the hands of people differ, reflecting all the fortunes of life, - the hands of the toiler made horny by the physical struggle for existence; the supple, self-expressive hands of the artist; the worn, disfigured hands of the machine tender; the tireless hands of the mother who does everything; and the characterless hands "that spin not and toil not, and yet are not beautiful. Beneath their soft, smooth roundness what a chaos of undeveloped character!" Highest of all ranks the hand which embodies fully the qualities both of science and of humanitarianism, _ " merciful gentleness and splendid certainty."

The Scriptures have touched the hands with idealism. We are told that we must have both a pure heart and clean hands. If the teacher feels something of this idealism, she will be able to impart it to the child. It is worth while to make a boy really feel the sentiment of honor toward his hands. 


\section{CHAPTER VIII}

\section{TOUCH AND THE APPRECIATION OF THINGS}

"Life is response to the order of nature." The measure of life, we might almost say, is sensitiveness to nature. The ancient psalmist has majestically catalogued nature's contents, - the heavens, the earth, and the great wide sea wherein are things creeping innumerable, both small and great beasts; the chariot clonds, the wings of the wind, the springs of the valley, the fowls of the firmament, the voice of the thunder, the grass for the cattle, the cedars of Lebanon.

The scientist, in language more prosaic but still poetically suggestive, describes nature in terms of the incessant forces of gravity, atoms, electrons, and tenuous waves of ether dancing through space at the rate of hundreds of billions per second. Our sense perceptions are the feelings which correspond to these varied objects and energies in nature, "whose radiant activity enfolds us all."

The whole body of the amœba is sensitive to contact, mechanical jars, light, heat, chemical and electrical stimuli. In creatures as humble as the hydra and the sea anemone there are special sensory nerve cells placed between the environment and the responding muscles of the organism. These sense cells are triggerlike devices which furnish the cue for responses and make them more prompt, certain, and varied. In the jellyfish there are special sense organs, eight clusters of them around the rim, for the light, chemical, and pressure senses. If these sense bodies are removed, 
the animal will no longer pulsate spontaneously, - which goes to prove the fundamental importance of sensation. Genetically, the sense organs preceded the development of the brain.

The sensory-motor elements of the nervous system are the most primitive, both in function and structure; but very early in the animal seale the locomotor system becomes sufficiently complex to require a central "adjustor." The natural place for this adjustor is in the hearl, the part that is foremost in all crawling, climbing, fleeing, and fighting. Thus even the earthworm carries a brain in his head.

The general character of any brain varies with the sensory equipment and the enviromment of the animal. Take the turtle: he lives in a world of odors; scent is all important in his life economy; his brain consists chiefly of two big, bulging olfactory lobes. In man, smell is " a fallen angel"; the olfactory lobes have dwindled to the size of a bean, and the bulge of our brain has a different reason, though possibly not a different origin, for Meynert has suggested that our cerebral cortex has its genesis in the olfactory lobes. In any case the organization and development of our cortex are indissolubly connected with the use of our sensory apparatus. It is the central switchboard, or adjustor, on which every sensitive point of our body is represented. The cortex is not only a sensorium, but it is so fundamentally a sensorium that its vigor and refinement depend primarily upon the sense impressions which have modified its structure. The degree in which our minds will be athletic and rsthetic depends upon what we have seen, heard, smelled, tasted, and touched.

The oldest, biggest, and most fundamental end organ we have is our sensitive skin, - 1,584,300 square millimeters in extent. Woods Hutchinson has called the human skin one 
of the wonders of the world,_- " a tissue more beautiful than velvet, more pliable than silk, more durable under exposure than steel." Havelock Ellis describes it as "the archæological field of human and prehuman experience, the foundation upon which all forms of sensory perception have grown up." Indefatigable explorers like W eber, Frey, and Goldscheicler have devoted a good part of their lives to the investigation of this archeological field. They have used the most ingenious and refined methods of experimental science for the discovery and mapping out of its many wonders.

'The amoba has no skin, but it is altogether possible that even in the amoba the peripheral protoplasm, or the part nearest to the enviromment, is especially sensitive to stimuli. If the amoeba has a stream of consciousness, it may well be because of some rudimentary contact-awareness, which Spencer considers the most primitive psychic phenomenon. Certain it is that almost as soon as nature begins to multiply and differentiate the cells in a single organism the ectoderm becomes especially sensitive to contact and pressure. Thus even in the skin of the hydra and sea anemone and in the outer covering of earthworm, frog, and lizard are scattered many sense cells. Ages and ages before man appeared upon the face of the earth there were "multifarious experiences with hardness." Hall enumerates in a suggestive way how "bottom creatures love crevices, develop responses to points, curves, compression, changes of permeability, cohesion, thickening, squeezing into holes, cracks, hugging against each other." In mammals, hairs become the instruments of touch. In the little trembling mouse, with its delicate fur of multitudinous sensitive hairs, general tactility is raised to a very high power.

Man, although he has lost much of his ancestral hair covering, is provided with hundreds of thousands of touch 
organs, - more, indeed, than seem necessary, as though nature had provided a reserve for the future development of his sensibility. Our whole cutaneous and subcutaneous tissue and mucous membrane are equipped with pressure cells, bulbs, and corpuscles, of various shapes and uses. Over a million delicate nerve fibers lead from these sensitive points to the spinal cord, and every pressure point associated with over a half million hairs gives a sensation qualitatively distinct. Besides this the extensive linings of our viscera are supplied with various tactile organs, and it may be that our very organic sensations which arise on internal stimulation are only special varieties and combinations of tactile impressions. Furthermore, there are extremely important pressure or touch end organs within the voluntary muscles themselves, and in the sensitive joint surfaces on which these muscles operate, and in the tendons to which they attach. The stimulation of this group of organs produces our tactile-motor or kinæsthetic sensations, which make us aware of all our movements of the fingers, arms, tongue, etc. Closely identified are the sensations of strain occasioned by muscular activity in overcoming resistance; and when the muscular activity is cadenced, we have the sense of rhythm. Thus our whole physical organism from finger tips to tendons and vitals is literally possessed by a myriad of tactile neurons. No other sense has such a wide domain. No other sense lies at once so all-pervadingly close to our personality and to our realization of the objective world. Tactility is the very essence of reality.

Consciousness of the outside world, and of the bodily self, begins with the vague tactile impressions of mouth, cheek, and body enjoyed by the baby when nestled in its mother's arms. In the early weeks the child is merely a passive receptor of tactile stimuli, and his attention does 
not rise above the plane of staring and wonder. But his nervous system, developing at a rapid pace, prompts him and enables him in due time to be actively curious and to accumulate tactile experience on his own initiative. This is active attention and active tonch. Fe begins to reach, to clasp, to creep, to walk, to tear, to build up. He gets into mischief and into a knowledge of things, and chiefly through the ceaseless manipulation of his prehensile organs, the hands. These are really end organs of perception of supreme importance. Nothing in the long onward march of the human species was more helpful and potential than the releasing of these organs from the brutal use of locomotion for manual dexterity and contrivance. Indeed, the contact experiences resulting from manipulation constitute the very " core of thinghood." The lower animals, in their manipulation, are limited to such clumsy organs as beaks, paws, claws, and jaws, and Professor Mead has raised the question whether the capacity of clear perception of physical things is therefore not limited to man.

When compared with sight and hearing, touch has been called an unintellectual sense, but such a statement is seriously mislearling. The most fundamental data for our perception of distance, direction, size, and form come through the feel gate. Only handling and manual activity can put vividness and content into the perceptions of the outside world. The child must begin in very infancy its acquaintance with the resistance and construction qualities of paper, sand, cloth, wood, etc. By gradual stages he gets farther and farther into the heart of things, and learns the essentials of what engineers call the materials of construction. If his opportunities are good, he will by tools learn the individuality of various woods, cardboard, leather, wire, fibers, clay, glass, stone, wool, cotton, and by dabbling 
acquire enough about every art to give him an appreciative apperception for everything that man has made. Our point is that he cannot get this appreciation by mere reading or listening or even observation. His skin and tendons and muscles must be stimulated before he gets the kernel of reality in any physical thing. For this reason much of the object teaching in the schools is not nearly so effective as is often fondly believed. It is only eye-deep, and what children need is the opportunity to handle and stroke. A picture is better than a word, a stuffed bird better than a picture of one, but nothing can take the place of putting a little live creature into the palms, where fifty thousand touch bulbs will tingle with the fluffiness of the feathers. Such a contact experience will establish a warm, tactile sympathy for the object, beside which a mere visual impression, however definite, is feeble and anresthetic. The do-not-touch principle, at school, home, and expositions, is unfortunately limiting.

There is a whole group of biological reasons why touch is of all the senses the most fundamental, not only for the development of intellectual perception but also for the growth of our æsthetic, emotional nature. Touch is chronologically first in the history of mind. With the possible exception of hunger, it is the most ancient of all experiences. There were touch sensations in the primordial sea where the earliest life began. 'There were touch sensations in the mud and on the land billions of years before the continents took their present shape and before man appeared upon the face of these continents. Touch is most intimately associated with the fundamental instincts of workmanship, hunger, sex, curiosity, fighting, and sympathy. Moreover, it is most vague, diffuse, and general in character. All these reasons combine to make it the most profoundly and massively emotional of all the senses, especially in childbood, 
when its ancestral values tend once more to emerge from the deep levels of the nervous system.

Harriet Martineau, in her autobiography, recalls how in childhood the touch of a velvet button affected her: "The rapture of the sensation was really monstrous." A little child may stroke a soft blanket with a delight so intense, and yet so reverent and tender, as to be almost spiritual. Through no other avenue does the child get such a wealth of artistic enjoyment. Who can number the thrills of pleasure every eager child gains by the mere stroking of smooth surfaces and rondures, polished woods and marbles, pebbles, silks, vegetables, fruits, animals? And what of the endless rapturous experiments with the textures, the pliancy, elasticity, and rigidity of all sorts of materials?

Then there are the larger dermal joys and adventures in which face and cheek, and sometimes the whole body, participate, - the big tactual experiences with the elements, fire, frost, cold, wind, mist, sod, beach, and sea. 'These massy experiences, though less discriminative than the delicate touches of the finger tips, are all the more bucolic and exuberant, for they are profoundly dyed with the interests, joys, and longings of the race; and there is a resurgence of feeling when the child reëxperiences them. Hence his orgy of enjoyment when he is free to wade, wallow, and splash in mud or water. Bareheadedness, barefootedness and on swimming and athletic days barebodiedness - are the biological rights of every child. Only by such generous exposure to wind and weather, to earth, water, and sky, can nature make those rich, massive inpressions which get to the depth of the soul. Every child needs a rich range of touch experiences, - of the delicate for the appreciation of things refined, of the grosser for the appreciation of things strong, stately, and sublime. 
Without touch, our capacity for asthetic appreciation would become emaciated. Even music, the most ethereal of all the arts, depends upon the tactile-motor part of our nature. Rhythm has a motor basis, and in the enjoyment of melody there is a kind of translation of ebb and flow and modulation of sound into spatial movements as vague tactile-motor excitations. The deaf can enjoy music because it is capable of this tactile transmutation.

Most of the arts address themselves to the eye; but even here the sentiment of beauty derives much of its force from the tactile and motor memories which are vaguely awakened whenever we behold a painting, statue, or cathedral. Without many varied tactile experiences with surfaces, and refined touch discriminations, and many explorations of outlines with fingers, pencil, chisel, etc., in the background of consciousness, we could never get into that vague but most real tactile-motor communion with the objects which our eye contemplates. This tactile-motor communion lends depth to our æsthetic reactions. Everything, however humble, which enriches the active and passive touch experiences of the child, will therefore contribute to higher æsthetic enjoyment.

As Helen Keller says: "There is more meant in things than meets the eye." "The wonderful rhythmical flow of lines and curves can be more subtly felt than seen." "I know," she says, "that the world I see with my fingers is alive, ruddy, satisfying." Sometimes the experiences are so enchanting that her hands quiver with pleasure, for touch, too, has its ecstasies and is eloquent. "In touch is all love and intelligence."

"The thousand soft voices of the earth have truly found their way to me - the small rustle in tufts of grass, the silky swish of leaves, the buzz of insects, the hum of bees 
in blossoms I have plucked, the flutter of a bird's wings after his bath, and the slender rippling vibration of water rumning over pebbles. Once having been felt, these loved voices rustle, buzz, hum, flutter, and ripple in my thought forever, an undying part of happy memories."

\footnotetext{
"In the worlds of wonderment where I dwell

I explore life with my hands;

I recognize, and am happy;

My fingers are ever athirst for the earth,

And drink up its wonders with delight,

Draw out earth's dear delights;

My feet are charged with the murmur,

The throb, of all things that grow.

"This is touch, this quivering,

This flame, this ether,

This glad rush of blood,

This daylight in iny heart,

This glow of sympathy in my palms.

Thou blind, loving, all-prying touch,

Thon openest the book of life to me.

The noiseless little noises of earth

Come with softest rustle;

The shy, sweet feet of life;

The silky flutter of moth wings

Against my restraining palm."
}

Well may she sing a Chant of Darkness, for in this dark ness touch is quickened, and in touch lives the deepest appreciation of things.

Though we cannot develop in every child the wonderful sensibility of Helen Keller, we can have more respect for the deep values that lie hidden in touch. They are often vague and nearly always inarticulate. Because these values cannot be put into words they have no recognition in the schools; but they can be communicated by teachers who show an enthusiasm for simple things. 
The sense of smell was perhaps the first to differentiate itself from the sense of touch. The end organ for smell consists of a specialized skin, or epithelium, sensitive to gaseous, chemical stimuli. In the reptiles and early mammals the olfactory areas constitute by far the greater part of the cerebral hemisphere. Olfactory experiences and memories constitute the major part of the stream of consciousness in these animals. The ancient and once dominant character of smell gives this sense a strange, compelling emotional force. But we have come to depend upon other senses for information and culture, and neglect the cultivation of the nose. This is probably inevitable, but not altogether deserving. Helen Keller declares that snell should hold a high place among its sister senses; and compared with this wonderful woman we are surely smell-blind. Every individual, except the babe up to about the age of sevell, has a temperamental exhalation which Helen Keller can detect. "Human odors," she says, "are as varied and as capable of recognition as hands and faces. The dear odors of those I love are so definite and unmistakable that nothing can quite obliterate them." For the smell sensitive almost everything, even in the mineral kingdom, has a distinctive odor. Poets have often shown a fine sense for the odors of mountain, field, and flowers, and sprinkle their verse with the perfume of olfactory metaphors. Surely that child is richer in experience, and in capacity to appreciate, who has sniffed delicately or inhaled deep drafts of the ethereal, the aromatic, and balsamic out of doors.

Taste is close cousin to smell, and depends upon reënforcement from smell. We can say little of pertinence about taste, though no doubt there is something to be said. The gustatory passages in Thoreau's essay on "Wild Apples" are particularly suggestive. 
The psychologist claims that the world of discernible sound vibrations comprises some 11,000 tones (and 850 noises!). These occur in infinite combinations, and a marvelous sensory apparatus, consisting of over a score of thousands of fibers, and hundreds of thousands of microscopic hairlets, picks up these varied vibrations so that they may become part of the soul. Sounds have an emotional power second only to odors and tactile impressions. Music is the language of the emotions. Melody and modulations are felt as well as heard, and the life of feeling shrinks if they do not in many forms find their way into consciousness. A child suffers whose auditory diet is limited chiefly to the American drawled, nasal voice and the noises of civilization. Every normal child has an instinctive interest in sound as sound or jingle, irrespective of intellectual content. Hence the many experiments in productive sound-play, both vocal and instrumental. What is the psychology of the universal joy in running a stick over a picket fence, or in the trampling of crackling autumn leaves? Ideally the child should be surrounded with a richer range and larger amount of music. A good gramophone in every school, generously used, would add much to sensory development, but more important still is that most marvelous of all sound-producing instruments, the human voice. Melodious and modulated voices in teachers would inscrutably, but none the less vitally, work wonders in the character and sensibilities of the children.

Finally, we come to vision, which boasts the most exalted position among the senses. It is peculiarly the intellectual sense, photographic in fidelity, panoramic in scope. It furnishes a wealth of material for the imagination. No organ is being strained more by the progress of civilization than the eye. The race is becoming eye-minded. Elementary education has long been so, and too much so. Important as 
vision is, it lacks vitality and depth. It is, after all, objective and superficial when eompared with touch, which Diderot called, of all the senses, the most profound and philosophical. Instruetion which is eye-deep is not very deep, and disproportionate reliance upon the seeing of things and words tends to eripple the sensory life of the ehild, especially of the primary child, who is ear-minded and touch-minded before he is eye-minded. Seeing implies merely an impression. Touch implies more. It implies an impression plus an emotional glow. No one, of course, would try to argue away the importance of keen visual perception and a vigorous visualizing power, but seeing without touch is innoeuous and sophisticated. Of primary importance are the tactile and motor experiences. 'These alone can make the physieal things tingle with values and suggestion. The child who does not have this well-stored background of tactile-motor experience may be the man who, though he has eyes, sees not. There would not be so many indifferent and inert people in the world if all ehildren eould eome into a more intimate and emotionally tinged taetual contaet with their environment.

We are not anxious in this chapter to make the distinctions of technical psyehology between perception, sensation, sense feeling, and appereeption. We do believe, however, that it is important to emphasize the difference between mere passive sense perception, or apprehension, and what we may eall the appreciation of things. Perception has been defined as a feeling of things present to the senses. Appreciation is a feeling for things, - an impression colored with a subjective attitude and leaving an afterglow of emotion. If the sehoolroom is allowed to be a word factory and the handwork and nature study become perfunctory and noetic, children will not be as appreciative as they might. Teachers 
and parents must have not only articulate knowledge of things but a kind of enthusiasm for things. They must come into the mood of the psalmist, and of the poet who said: "I believe in the flesh and the appetite. Seeing, hearing, feeling, are miracles, and each part and tag of me is a miracle." It is a common error to think that the emotional part of our nature is to be reserved for state occasions, for weddings, elections, and birthlays. As a matter of fact, a sensitive nature attaches certain emotional sense feelings to such simple stimuli as an isolated color or a single musical tone.

One of the besetting sins of the primary school is languor, apathy, - apathy in speech, in movement, in action, and apathy in perception. This springs from the insidious overvaluation of words. The teacher has an overrespect for words, forgetful that they are the technique and not the ingredients of culture. This bookishness and wordiness start often with the very first day of school, and develop a precocious use and misuse of words that amounts to pedantry. Pestalozzi realized that this was one of the evils of primary education, and in the year of our Declaration of Independence he makes the two following entries in his diary:

"O God, who art my father and the father of my child, teach me to understand the holy, natural laws by which Thou preparest us slowly, by means of an innumerable variety of impressions, for the conceiving of exact and complete ideas of which words are but the signs!"

"Lead your child out into nature. Teach him on the hilltops and in the valleys; there he will listen better. But in these hours of freedom let him be taught by nature rather than by you. Let him fully realize that she is the real teacher, and that you with your art do nothing more 
than to walk quietly by her side. Should a bird sing, or an insect hum on a leaf, at once stop your talk. Birds and insects are teaching him. You may be silent."

Education is too often confounded with verbal instruction and recitation and word drill. As a matter of fact the deepest and most educative experiences are wordless contact with things. The teacher may hold the hand of the child, as Pestalozzi did when he took his Jacobli into the mountains, and may quietly smile in enjoyment of the hum or the song or the glimmer, hoping that by suggestion the child may catch the smile and thus the beauty; but words are of no avail. This is what Stevenson had at heart when he wrote his convineing apology for idlers. He spoke with pitying contempt of the extreme wordy busyness of the schools, which tend to produce "a sort of dead-alive, hackneyed people, who are scarcely conscious of living except in the exercise of some conventional occupation." "Books are good enough in their own way," he says, "but they are a mighty bloodless substitute for life." It is not through heroic word drills, but "by looking out of his eyes and hearkening in his ears with a smile on his face" that the child will acquire "the warm, palpitating facts of life," which is true education.

Emotion is everything. If perception is allowed to degenerate, because of the listlessness in schools and home, into cold apprehension, untold harm is done to real moral and temperamental development. We are not pleading for keemness of sense so much as for emotiveness. The senses are considered as servants of the body; they should be exalted into the service of the soul. Every one feels the beautiful spirituality of Helen Keller's nature, but it would be a sad error to conclude that this is due to the fact that she has been shut out from the world of sense. Read her 
fine encomiums of the black-sheep senses, touch and smell, and you will realize that the very foundation of her spiritual power is rooted in the wealth of emotion derived from the loving use of these bodily senses. One could even argue that her spirituality would have suffered had the curtain of night been raised from her eyes. Vision is so objective, and may be so superficial, as actually to handicap moral growth. It would be a boon if we could live a little more in "the wise, vital, thought-quickening dark," - in the twilight regions of that most profoundly emotional sense, touch. Every atom of Helen Keller's body is a vibroscope. Sweet, beautiful vibrations exist for her touch, and we who control the sensory development of children should heed her exhortation:

"Hold out your hands to feel the luxury of the sunbeams. Press the soft blossoms against your cheek, and finger their graces of form, their delicate mutability of shape, their pliancy and freshness. Expose your face to the aërial floods that sweep the heavens, 'inhale great drafts of space,' wonder - wonder at the wind's unwearied activity. Pile note on note the infinite music that flows increasingly to your soul from the tactual sonorities of a thousand branches and tumbling waters. How can the world be shriveled when this most profound emotional sense, touch, is faithful to its service? I am sure that if a fairy bade me choose between the sense of sight and that of touch, I would not part with the warm, endearing contact of human hands, or the wealth of form, the mobility and fullness that press into my palms."

The appreciation of things mounts to its highest flight in the spiritual and poetic nature. Primitive man actually worshiped, and with deep feeling, mute rocks and cliffs. For Wordsworth, even the loose stones that pave the common 
highway respired with an inner meaning. When the spirit of appreciation wells up in the poet, it knows no bounds. It reaches out and embraces all the manifold objects of nature, animate and inanimate, - the ligh vibrating stars, the rolling ocean, the gorgeous clouds of sunset, the growing wheat, silent plants, and creatures dumb. For all of these the poet feels a high and tender kinship, endows them with one kindred impulse, and speaks in words of almost loving companionship to the mountain daisy or to the wee cowering beastie in the stibble. For Burns even the mousie is a poor earthborn companion and fellow mortal. Sidney Lanier, in his fervent poem, "Sunrise," addresses with affectionate appeal the "Sweet, burly barked, man-bodied trees, O beloved, my live oaks," and begs of their foliage to teach him the terms of silence. "Ye ministers meet for each passion that grieves, friendly, sisterly, sweetheart leaves!" Here appreciation rises to the ecstatic pitch of animistic comradeship. This is the poet's privilege and the child's inclination; for poets are childlike, and the child is by nature a poet.

The instinctive psychoses so intimately associated with touch make this sense extremely important for morality as well as asthetic enjoyment. For morality has its being in our instinctive, impulsive, emotional attitudes, — not only attitudes toward persons, but toward things, minerals, plants, and animals. In some inscrutable way refinement of sensibility is correlated with delicacy of moral sentiment, and coldness of perception with coldness of character. The very etymology and double connotation of adjectives like coarse, supple, dainty, rude, and delicate, betray a fundamental relationship between tactile and ethical qualities. Manners and wood both are smooth or polished; and conduct, lace, and wire may all be fine. It cannot be demonstrated 
in the laboratory, but undoubtedly the tactile tenderness with which a rough street boy handles a collection of delicate butterflies in some way irradiates into the sphere of general conduct and softens his deportment.

There are tactile-ethical values in nature study and handwork: the tactile attitudes of tenderness and protection which a boy feels for fragile birds' eggs carefully stored, perhaps with a caress, in cotton; the perfect polishing of a wood surface; the respect for the fiber and individual resistant qualities of material; the rounding of edges and corners for comfort and beauty; the obedience to lines, drawings, and so forth; the accuracy and truthfulness in fitting edges; the general submission to the laws of nature whenever a piece of raw material is attacked. We can suggest rather than demonstrate the important bearings of all this.

See how a child will stroke a smooth surface with half awesome delight. What does it mean? It means that life is more than words. In due time, of course, the child should be able to speak and spell a declarative sentence, stating that the sensation felt exquisite. Sometime he may even discuss whether "rapturous" is a better adjective. But, after all, the adjective is but a tag or a symbol. The sensation itself is unutterable. Character is made up of attitudes, appreciations ; and verbal images, although very essential to abstract thinking, are idle and void unless they are born of concrete contact.

The psychology of peoples has been molded by the great silent geographical and geological features ever present in their environment. The prairie is in the Indian, the mountain in the Swiss, the sea in the Eskimo. The qualities of things great and small, visual and auditory, but especially tactual, by some half-mystical process sink through 
the thin layer of the intellect into the deeper strata of the heart, especially the heart of the child.

Since the process is half mystical it baffles descriptive psychology, but the poet seems to know how to tell it. The following is selected from a poem by Walt Whitman, which is one of the most understanding things ever written about childhood.

There was a child went forth every day, And the first object he looked upon, that object he became,

And that object became part of him for the day or a certain part of the day,

Or for many years or stretching cycles of years.

The early lilacs became part of this child, And grass and white and red morning-glories, and white and red clover, and the song of the phobe bird,

And the third-month lambs and the sow's pink-faint litter, and the mare's foal and the cow's calf,

And the noisy brood of the barnyard or by the mire of the pond side, And the fish suspending themselves so curiously below there, and the beautiful curious liquid,

And the water plants with their graceful flat heads, all became part of him.

His own parents, he that had fathered him and she that had conceived him in her womb and birthed him,

They gare this child more of themselves than that, They gave him afterward every day, they became part of him.

The mother at home quietly placing the dishes on the supper table, The mother with mild words, clean her cap and gown, a wholesome odor falling off her person and clothes as she walks by, The father, strong, self-sufficient, manly, mean, angered, unjust,

The strata of colored clouds, the long bar of maroon-tint away solitary by itself, the spread of purity it lies motionless in,

The horizon's edge, the flying sea crow, the fragrance of salt marsh and shore mud,

These became part of that child who went forth every day, and who now goes, and will always go forth every day. 
It would spoil this poem to comment on it analytically. Could there be a finer statement of faith in education, of faith in the subtle power of all things upon the growing child? Heredity is only half. The teacher, too, becomes part of the child who goes forth every day to school, and in largest measure if she communicates to him a loving appreciation of the commonplace things which will always surround him. 


\section{PART THREE}

\section{THE PEDAGOGY OF THE PRIMARY SCHOOL}

\section{CHAPTER IX}

\section{DRAWING}

The period of childhood is a period of self-revealing expression. One of the most charaeteristic and interesting forms of such expression is drawing.

Spontaneous drawing is really a form of play, and in the early years ehildren need about as little instruction in drawing as they do in any play. It is instinctive for a child to test his powers, to externalize himself, to leave a mark. He takes instinctive delight in being a eause, and even before his first birthday he may seize a pieee of chalk and scrawl with it.

These earliest scribbles are of eourse an expression of the instinct of workmanship hardly less erude than the random, aimless kicking of legs and brandishing of arms in the erib. There may be an element of imitation in the activity, but there is no eonscious purpose or design.

The seribble period, aceording to-Lukens, who studied and elassified hundreds of children's spontaneous drawings, lasts until about the age of four. If a ehild did not rise to a higher type of expression in this time, it would be a case of arrested development. Just as his play becomes more and more expressive of ideas and models, so does his penciling; 
he does not forever shove and fumble his blocks, but he arranges them in rows, walls, and pillars. That is, he externalizes mental states in objective construction; and what is drawing but this? Even when he crawls about on all fours in imitation of some quadruped, he is indulging in a form of representative behavior which is psychologically akin to

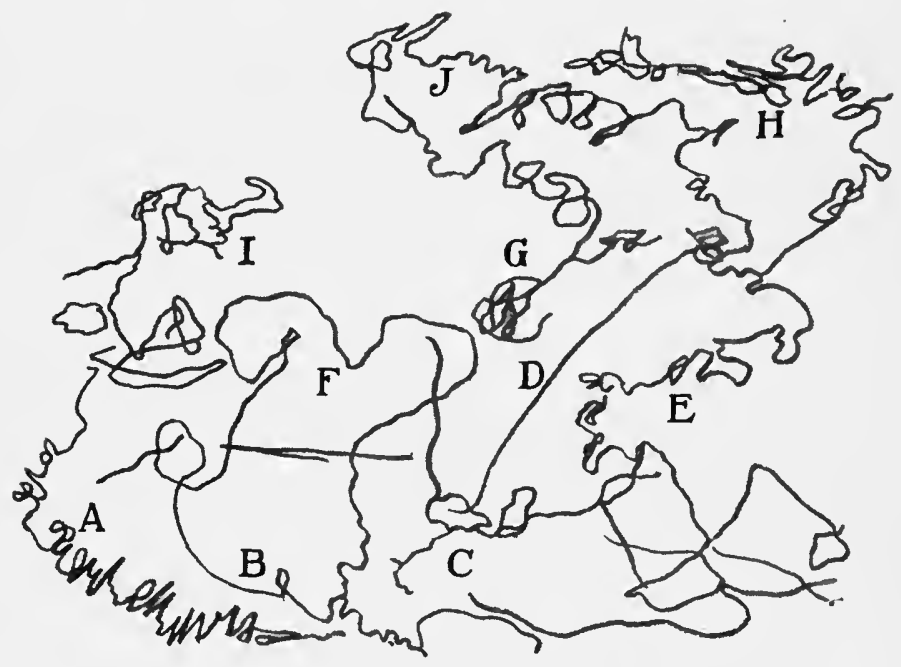

Fig. 23. Seribile and Representatiox

$A$, airship ; $B$, hippopotamus (a bad one) ; $C$, comet; $D$, comet's tail ; $E, \operatorname{dog}$; $F$, balloon; $G$, cap; $H$, hippopotamus (a good one); $I$, children on a giant's back; $J$, spider

drawing; for primitive drawing is a kind of pantomime with a pencil point, or graphic gesture. Early childhood drawing is essentially language, and when the child gives his scrawls names, they can no longer be called mere scribbles.

In the second period of its development drawing becomes representative. 'This representative stage falls between the ages of four to about ten, but there is no sudden transition from one stage to the other. In fact, the scribbles of the early 
period are themselves often crudely representative, as indicated in Fig. 23, where the marks stand for a dozen different things, from a hippopotamus to an airship. A kindergartner once took a band of children, all under five years of age, to see a cow. They were asked to draw what they saw. At first sight the drawings looked like a collection of the rudest

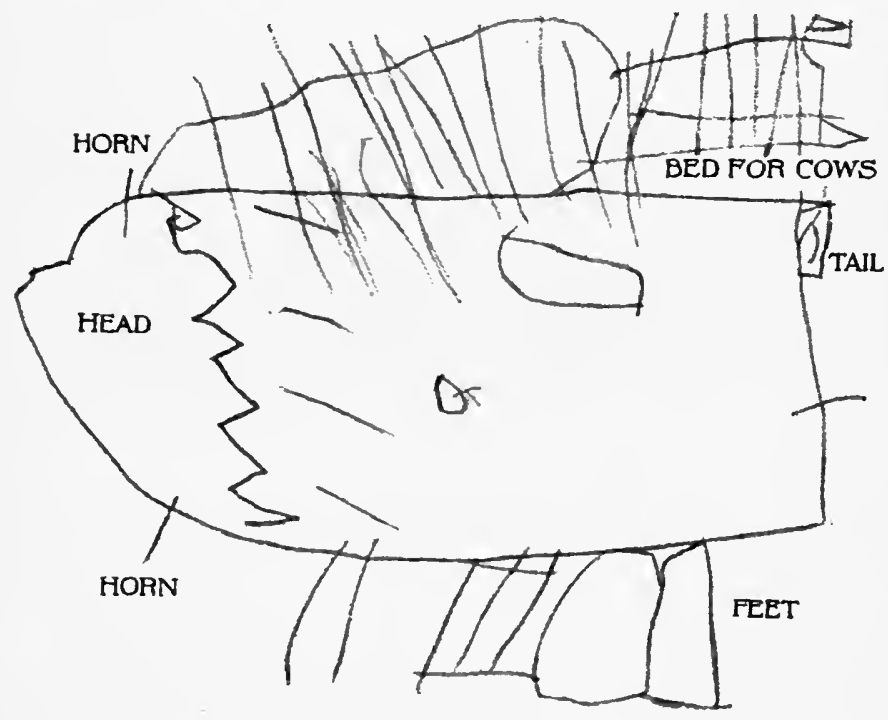

Fig. 24. A Cow

Kindergarten representation after a trip to the dairyman

scrawls, but close examination showed evidences of articulate expression, - here and there a controlled mark to represent the head, tail, or udder of the cow (Fig. 24). As Empedocles explained the development of animals by the assemblage of their constituent parts, so even in this chaos there was an evolution of definite wholes, - drawing in the making.

The most primitive scribbles of the nursery are made in pure enjoyment of motor activity for its own sake, but the 
kindergarten and primary child awakening to a new sense of his powers makes marks in the spirit of true language. $\mathrm{He}$ is in the golden age of imitative, dramatic, and creative expression. All his play is full of self-illnsion, and so is his drawing. Form is for him but the symbol, not the mirror of reality; hence his splendid disdain for accurate outline and his beautifully naïve interest in the meaning or the story. Unembarrassed by compunctions about fidelity and proportion, he draws out of his head and out of his heart.

We may smile at his crude productions, but for him they glow with the warmth of his own personality and throb with life and action. Drawing for him is language, not indifferent and clumsy portrayal of the objective world. He draws what he knows, not what he sees. He draws the foot in the shoe and the core in the apple, for though invisible he knows they are there. He will even draw action, dancing, sunlight, and the wind. He loves to project his experiences where he can enjoy them and make them more distinct to consciousness. By this process of externalizing the internal he comes into nearer kinship with his environment. Drawing is therefore highly educative; but if it is not related to his own experiences, and ceases to be selfexpressive, it becomes merely a reproduction of the external, and cannot stimulate growth. This at least is the conclusion of the psychological point of view.

The logical viewpoint ignores the child's natural interest and misinterprets his capacities. It regards drawing as a technique to be imparted to him in a progressive, systematic manner, beginning with simple straight lines, curves, angles, and elementary geometric forms. The argument is like that which used to be applied to the teaching of reading: The English language is made up of letters, let us teach these 
simple elements first, and proceed logically from them to syllables, words, and sentences.

Froebel, whose writings often contain a singular confusion of the logical and psychological points of view, said: "As the drawing of lines precedes the drawing of figures, so also there proceeds from it the invention of forms, ascending to imitation and copying; and further, after the pupil has made the required progress in geometry and mathematics, perspective drawing, instruction regarding light and shade as well as drawing from nature, landscape drawing, etc., will follow. The last aim, as everywhere, is the representation of man; that is, the representation of the human figure." In a certain kindergarten manual, still widely used, the author recommends that even "in free drawing the child should use a line of a certain kind or of several kinds indicated, with some restriction grouping these either to symmetrical forms or to representations of objects; that is, so-called forms of life."

It sounds very logical that simple lines should be mastered first, and that cylinders and cones should be mastered before trying to draw a complex thing like a tree, whose trunks and branches are combinations of cylinders and cones. Such pedagogy seems very reasonable and considerate, but it is really timid and false, because it thwarts the natural manifestation and expansion of the child's power.

'The primary child is in the expressive, language period of development, and every opportunity for expression should be open to him. If we limit him to a line of a certain kind, or to blocked-out squares or certain prescribed subjects, his drawing will become rigid, wooden, cramped, and expressionless. Give him a mood, something to say, something to illustrate; give him large undemarcated spaces, like the blackboard, so his expression may be full and free. He will 
flinch at nothing, and with fine abandon he will make the chalk tell his experiences, even though they may be as complicated as a circus parade. Froebel would make the human figure the last aim; with the child it is the very first, for his interests and not his eapacities determine what he will draw. Lukens, who collected over twelve hundred spontaneous drawings by children under ten, found that 75 per cent of the specimens contained the human figure. If drawing were mere tracery imitation of external objects, the child might balk at difficult subjects, and surely he would not draw such invisible things as the wind, the sunlight, and motion. But he draws what he knows and what he feels, and there is no better way of developing his knowledge and feeling than by giving him a chance to express both.

Take, for example, the sense of humor, which receives such scant recognition in school life. Little children have a very decided and promising fund of humor, even though the opposite has been supposed, and those who doubt the fact will perhaps be partly convinced by the accompanying funny drawings, which were made without instruction or suggestion by kindergarten and primary children. Fig. 25, $B$, represents a girl, who is funny because she has such a gigantic hand; Fig. $25, C$, is a half cow, with only two legs ; Fig. 25, $D$, is rather obscure, but is comical to the artist, who said that it was "a strawberry all squeezed up from the rain, and a funny pig with his nose sticking up and a flag on his back." All these drawings were made by kindergarten children.

Most of the other pictures in Figs. 25, 26, and 27 were drawn by first-grade and second-grade children. They speak for themselves, and the sympathetic sense of humor of the reader must be depended upon to do them full justice. It is unfortunate that we eannot reproduce the 


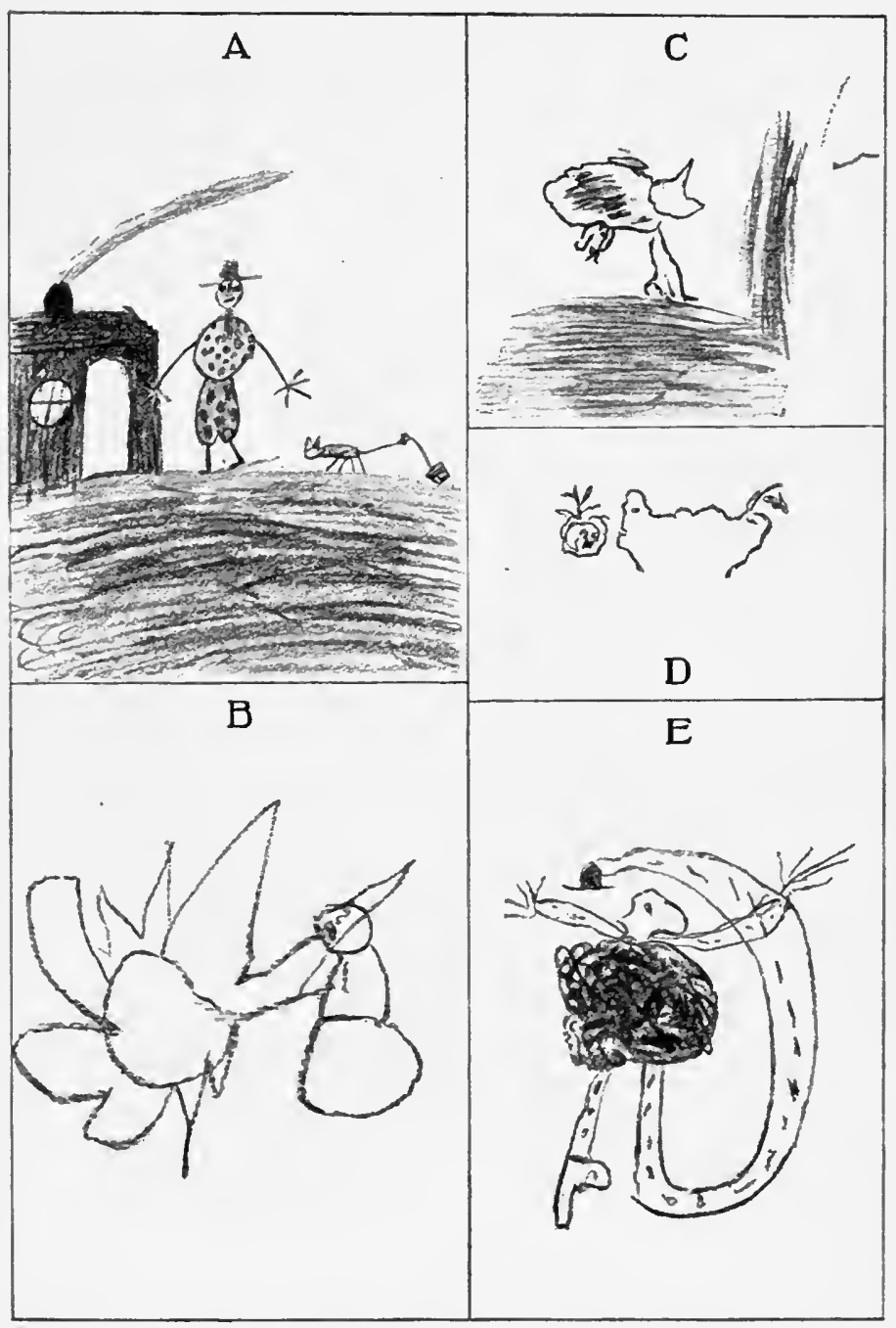

Fig. 25. Hemorots Drawings 
chuckles and the expressions of extreme delight which sometimes accompanied the working out of these comical conceptions.

The chief ingredients of elementary humor are embodied in these drawings: grotesqueness, both in color and design (for example, see Fig. 27, C) ; incongruity, in the haberdashered horse (Fig. 27, B); exaggeration, in the prolongation and uniting of the tails of the two dogs (Fig. 26, A); surprise and unexpected action, in the man who stands on tiptoe and manages before your eyes to kick his hat from his own head (Fig. 25, E) ; physical discomfort, in the boy about to be struck in the nose by a ball (Fig. 26, D), in the dog with the can tied to his tail (Fig. 25, A), and certainly in the poor man (Fig. 27,D) with his hands full of newspapers, who is being tormented from head to foot by a monkey, a bee, and a dog, with prospects of further discomfort from the vulture overhead.

Among the third-grade drawings are indications of humorous situations as well as simple character sketches. In Fig. 26, $B$, we see three boys indulging in antics on a stage, and a giant's finger, represented by the line on the left, is dragging the boys behind the scenes. Fig. 26, $C$, represents a goat who wanted to have some fun on the Fourth of July, and who therefore butted a hot stove among firecrackers and skyrockets!

The ten-year-old boy who drew Fig. 27, $A$, cannot discuss the principle of mistaken identity in comedy, but he explains the humor of his drawing in these words: "The funniest thing I ever saw is this picture becous it has its colars in such funney places. I think it is the funnist thing becous it is to represent 'Jack be nimble Jack be quick Jack jump over the candle stick,' when it is not Jack at all, only a picture of a kangaroo jumping over a candle stick," 


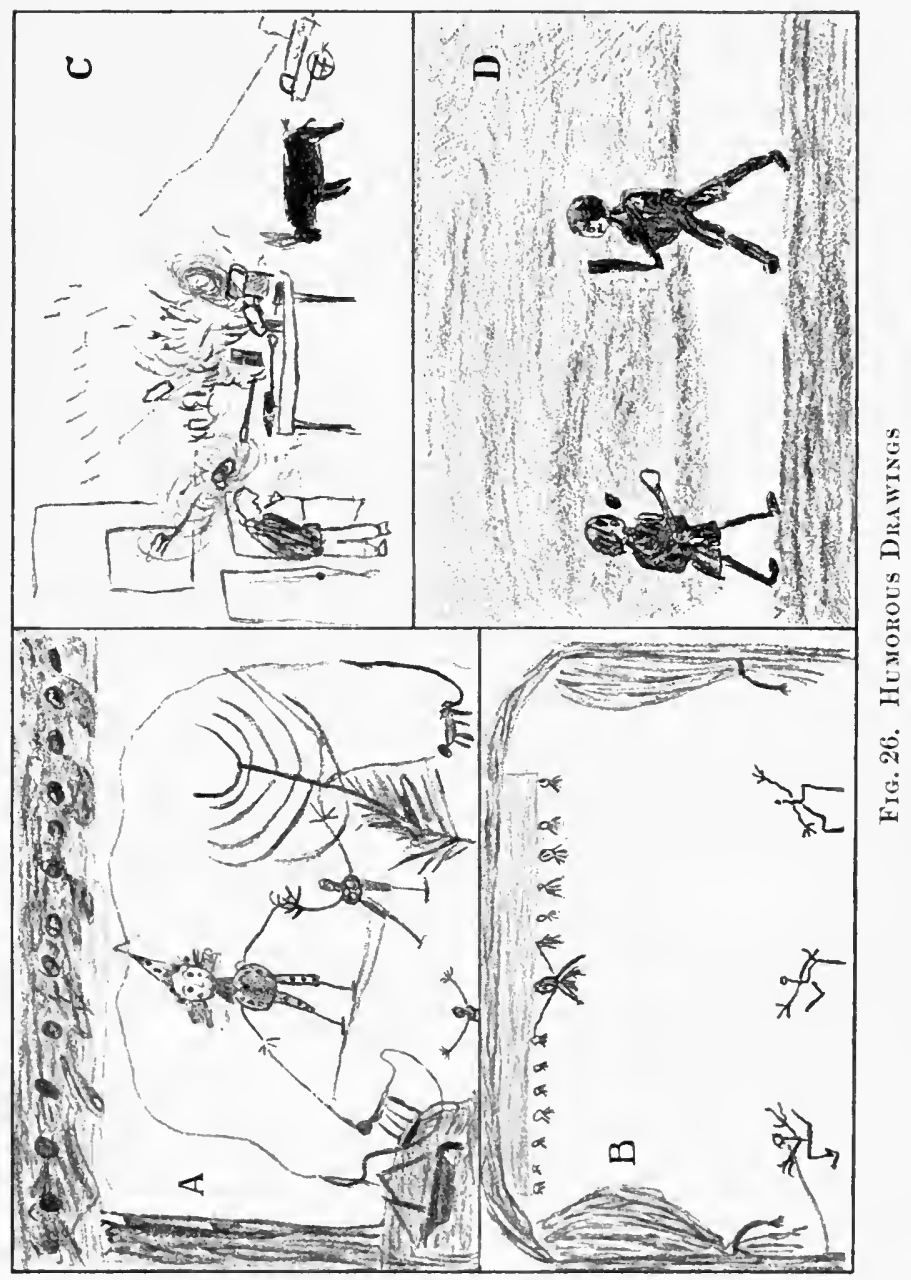




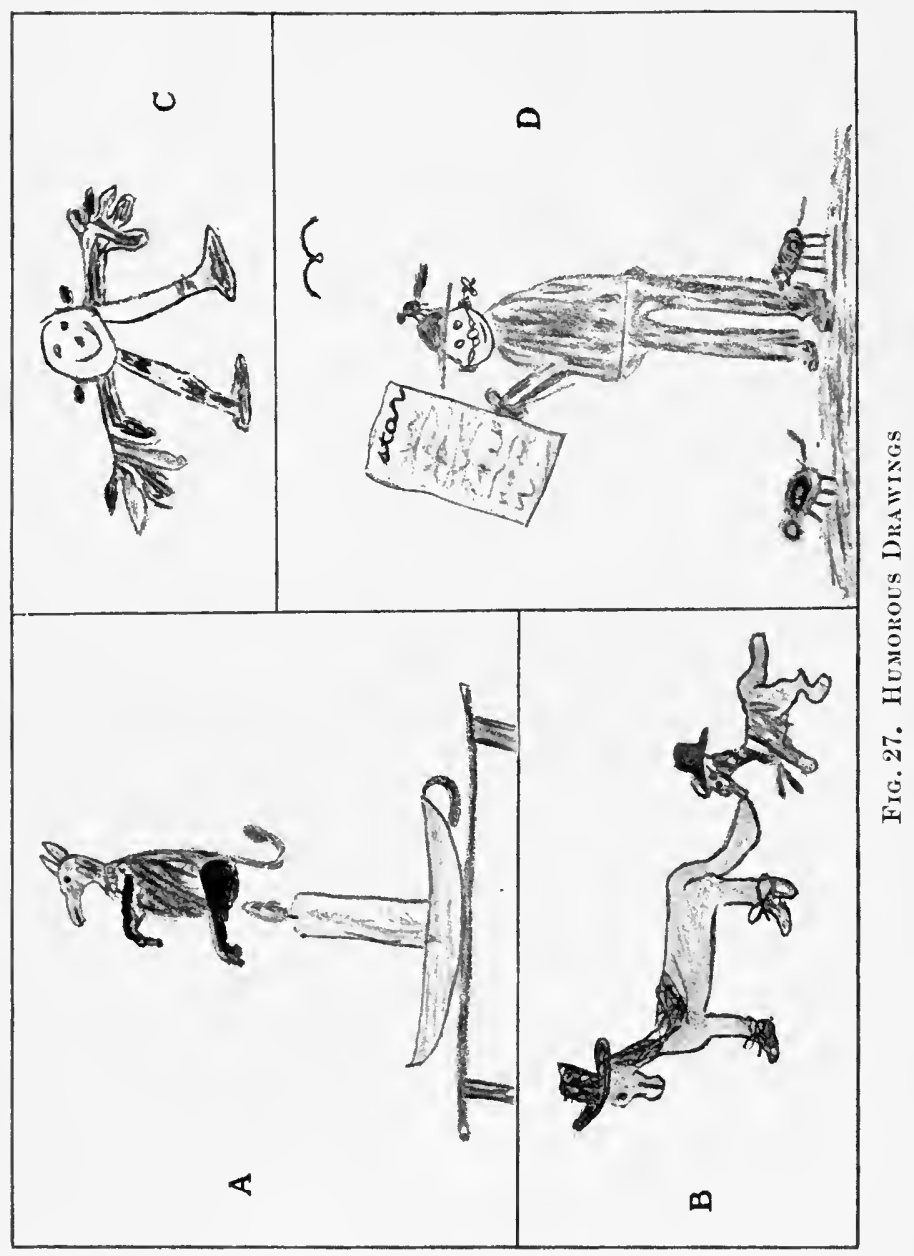


This is no place to go into a discussion of the interesting problem of humor in children, but these drawings strongly declare the existence and educational possibilities of their humor sense. It should be said that these drawings are not unusual; that they are little more than casual selections out of a small number of specimens. The sense of humor is present in all normal children, and drawing furnishes a fine avenue for its expression. We asked a boy of five if he could draw something funny for us. "Can I!" he said. "My head is just full of funny things"; and soon he was at work with absorbed attention and chuckling laughter. One of his productions he called the "Duke de Callaboose," and he proceeded at once to dramatize him. The serious school may have no place for the dramatic rendition, but drawing, with all its humorous life and action, is in a sense a mild and eathartic kind of dramatization.

Humor is one of the most valuable and beneficent traits in human nature. In its highest forms it means sympathy, insight, philosophy, originality; but these higher expressions are derived from the lower, and children's humor is not to be despised simply because it is primitive. Moreover, it is not nearly so crude as we are accustomed to think, and it responds wonderfully to suggestion and cultivation. Considering the limited experience of primary children, their comic productions are very creditable. The best of them are positively creative in spirit. The attention of the children while they worked out their comic inventions was unusually intense. This is itself a significant fact.

Humor is too precious to go to waste and to be left altogether to chance. The child who has a good supply of it will meet life better than the child without it. The child's natural genius leads him to select the salient and the vital. The earicaturist is the keen but smiling man of 
insight in whom this genius has not atrophied, and who can express it through his drawings as he crudely did when he was a child. The drawings of Figs. 28 and 29 were made by a grammar-school boy, and represent the fruition of the humorous drawings of the primary grade.

Drawing has a threefold significance, says Dr. Burnham in his excellent article on the hygiene of the subject: "first,

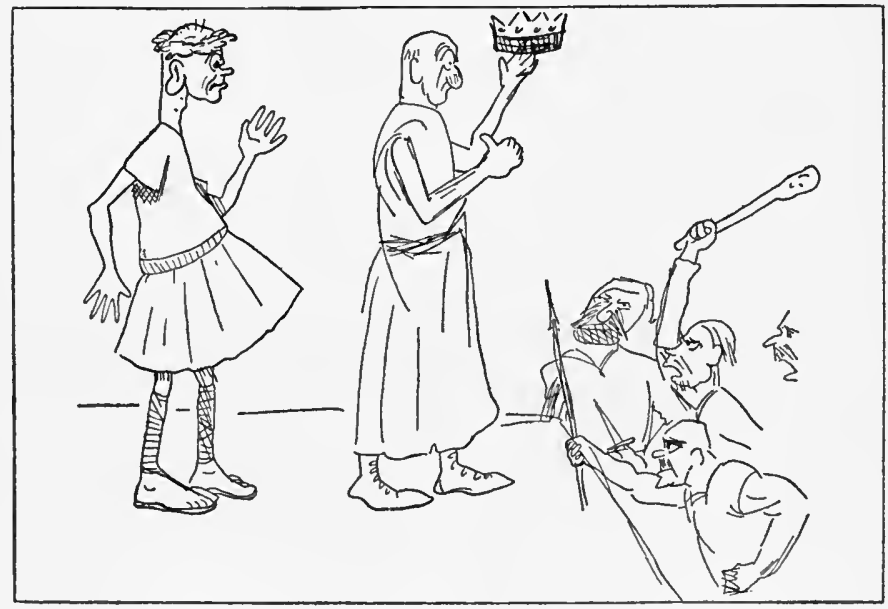

Fig. 28. Chasar refusing the Crown

A cartoon by a grammar-school boy

as a form of natural reaction to feeling; second, as giving the satisfaction which comes from productive activity and social expression; third, as developing an interest in art through the possibilities of imitation. From the ordinary point of view of hygiene this is vague, but the psychiatrist and the teacher who appreciate the importance to health of a normal life of feeling, of the satisfaction from successful activity and the balance which results from culture interests, cannot fail to see the positive hygienic significance 
of drawing and similar forms of artistic expression." The lumorous drawings described above offer a very good illustration of all these points.

Among the forms of artistic expression to which drawing is closely related may be mentioned dramatic impersonation, lancing, paper cutting, paper tearing, clay modeling, writing, and even oral language. Some of these relationships

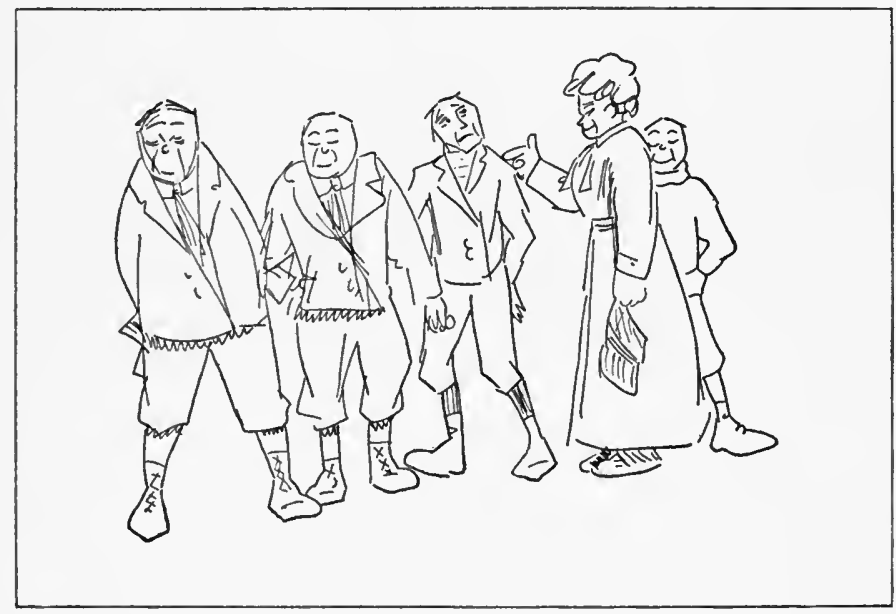

Fig. 29. A Dull Teacher

Another caricature by the same boy

we have already suggested. What a child imitates with his whole body in dramatic play he will gladly portray on the blackboard; or what he has just drawn he will readily impersonate, as did the author of the "Duke de Callaboose." 'Teachers could work out very good exercises embodying the reciprocal use of these two modes of artistic speech, - drawing and dramatic play. Children like to talk about what they have drawn, and their sketches furnish an excellent opportunity for enthusiastic language work, 
conversation witl a real motive and subject. Expressionless children who can usually be drawn out only with difficulty can be awakened to fluent oral language through spontaneous drawings.

The production and interpretation of pictures, it is admitted, preceded the printed page in the history of the race, and so it should be with the child. 'The folly of bringing the technicalities of reading and writing to unorganized minds is nowhere more evident than in the character of children's early drawings. 'The detail, the sequence and organization of the printed page, are conspicuously absent in these drawings; but the advantage of drawing lies precisely in the fact that it is a more instinctive and fluid medium of expression, - that it favors rather than impedes mental organization. A child whose reading and writing lessons have been preceded by a liberal use of free drawing comes with a mind better organized for these less instinctive tasks. 'The good teacher will make many connections between the pictographic and the typographic art. She will have children label their drawings with words and phrases, and their words with drawings. She will have them fill out their sentences, rebuslike, with sketches; and will allow them to illustrate in their own way the readers and dictionaries which they will make. Stories told by words can later be retold by chalk or crayon, and handwork may be both preceded and supplemented by drawings. In a following chapter we shall show how the work in writing can make many connections with drawing; but even if such connections could not be made, large free-hand drawing would still have the great advantage of establishing a poise and muscular control which will facilitate greatly the acquisition of the technique of penmanship. Drawing gives the fundamental muscles their needed development. 
But we must always come back to the vital point, that the supreme value of drawing for primary children lies in the fact that it is a fluid medium of expression for both thought and feeling. If the teacher, in blind obedience to mimeographed prescriptions or the course of study, uses drawing in a formal manner, aiming chiefly at the mastery of technical ability, the subject loses its chief value for little children. Drawing in the primary school should be regarded as an elastic vehicle of expression, not as a kind of motor dexterity. It should link itself to the children's own interests, images, emotions, and should bespeak these rather than a cunningly planned system of logical adult exactions.

Many of the systems in use at this day make this insidious mistake of trying to suit the technique of drawing to the child, instead of simply giving the child a free and less-charted opportunity for real expression. These systems often look modern, and are in reality superior to the old stigmographic and network methorls, but still they fail to appreciate the significance of a volume of free expressive drawing during the golden period of artistic illusion.

All truly expressive motor activity has a deeply educative effect which cannot be judged by the ephemeral outward results. This is especially true of drawing and paper cutting, if they are abundantly used. Both favor good posture, decisive muscular control, and self-reliant executiveness. 'To successfully draw or' cut what he thinks or feels, has a profound reflex effect upon the ethical nature of the little artist, giving him a sense of power and that fine feeling of moral joy which go with all artistic production. The spirit in which the paper cuttings in Fig. 30 were made was enough to justify them, irrespective of all technical considerations. The second-grade children who made these drawings were of many different nationalities, and came from wretched 
homes in a large manufacturing town. The class had been studying the subject of transportation, and what they felt and knew they expressed by their fingers with wonderful eagerness and ease. It took them only a very few minutes to take out their materials and cut all these vehicles and put them in the visitor's hands. Thanks to the atmosphere and instruction of the school, these children cut paper expressively with about as much assurance and alacrity as they spoke sentences.

This is the ideal for primary drawing. When drawing ceases to be merely a prescriptive exercise, and becomes a natural, easy means of expression, then it will do its most for the education of the child. Drawing instruction in the public schools should not become "the grave of talent and naturahess." Chamberlain quotes Dr. Heim as saying, "Many a fifteen-year-old boy and many an adult can, for example, no longer draw the picture of a bird which at the age of from five to ten years he was able to make before any instruction in drawing."

Why is this? Chamberlain thinks because "the delight in drawing which reigned in earlier years has been suppressed under the weight of method and direction. The child's own book filled with innumerable sketches of ahmost every object disappears before the sheet with the correctly drawn ornament or geometrical figure. Life no longer calls to him to represent it; the deadest of dead things are fashioned by him at the beck of others." It may be added that even leaves, vegetables, and fruit may be half-dead things if the children have no artistic mood or motive in their production.

We must preserve the naïve delight and daring of natural childish drawing. At about the age of ten the child perhaps inevitably takes some interest in techmique. He sees 


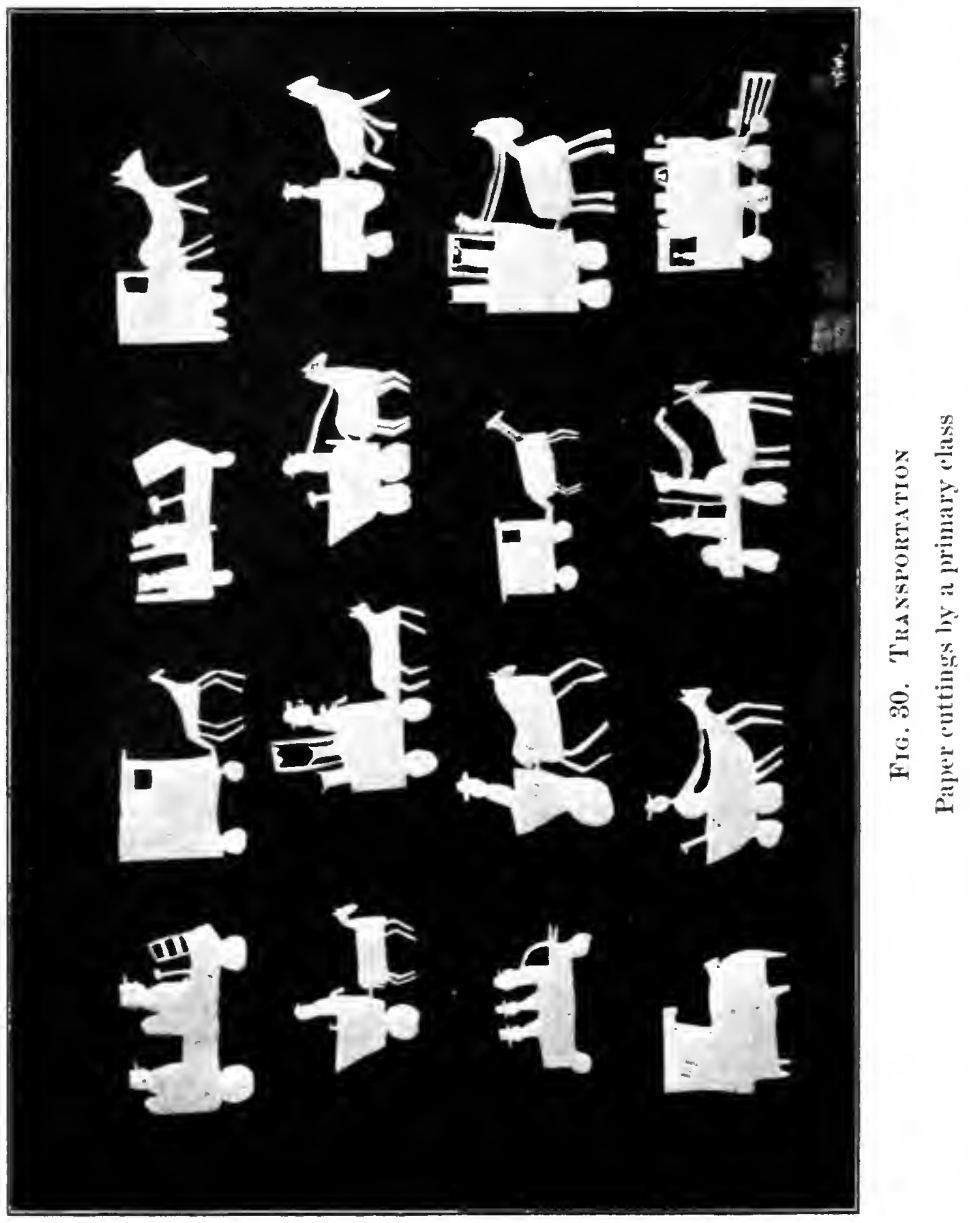


the disparity between the reality and his representation of it, and the period of self-conscious criticism sets in. This is, according to Lukens, the third stage in the evolution of drawing, which may be followed by a fourth stage, beginning about the fifteenth year or later, "when for some fortunate individuals, favored by environment or other stimulus, adolescence exhibits a recrudescence of the old creative power, a reinvigoration of the pristine love of producing"; but for most people the golden age of expressiveness, with its enchantment of artistic self-illusion, vanishes forever.

Inability to draw is almost universal, and even many of those who can draw fairly well in the art class, do not carry this power into their lives, do not enliven their letters with sketches, or, if they are teachers, do not talk with the chalk in that daring, suggestive way which fascinates children and vivifies all instruction. It is as if drawing were a dead language, which, like Latin, remains dead even after years of study of grammar and technique. Or have niggardliness in the use of drawing, and the unpsychological methods of presentation, developed a kind of compulsive fear and embarrassment, equivalent to stuttering in oral language? There is no need of overlaboring the suggestion, but the fact remains that the use of drawing as a means of expression suffers almost universal arrest and atrophy. "For every ten geniuses of drawing in the nursery, there remains hardly one in the high school. We are killing the art that made art." Even children in the kindergarten, working freely with the broad side of the chalk, will, after a little practice, produce landscapes possessing a real if elusive element of creativeness in them, pictures which might at least find a place in some collections of impressionistic art. And when steaming battleships, 
fighting Indians, and rumning deer are drawn, the lines are often salient and dramatic enough to be called truly artistic. The spirit and the power which are latent in these drawings it is the duty of the schools to nourish. Nowhere does Schiller's observation seem more applicable, that if we all lived up to the promise of childhood, we should all be geniuses. 


\section{CHAPTER X}

\section{DRAMATIC EXPRESSION}

The purpose of the introduction of dramatic play into the schoolroom, like so many good things too enthusiastically received, is being sadly misunderstood. The teacher with initiative seizes upon the suggestion without due consideration, interprets a bit of literature, persuades the children to memorize her interpretation, and presents a finished product to a host of admiring mothers who are unfit to criticize its educational value.

Dramatic play, the strength of which lies in artistic elusiveness, fluidity, and personal interpretation, is a con structive art, and in the process of construction lies its value. The inspired artist who gives birth to a masterpiece projects it but once upon the canvas; the victorions seulptor destroys the mold that there may be no imitators.

Dramatic play, to be valuable, shonld be born of the child's imaginative genius and should bear the stamp of its crudity. It should be bold, suggestive, primitive, like his drawing. Both are his interpretations of life, - the one, gesture transferred to paper; the other, gesture of pantomime or dramatic representation. 'The development brought about by each is due to the creative attack, the quick, suggestive interpretation of thought, and also the increased curiosity in regard to life. The time and effort given to a finished play, therefore, exceed the results obtained. In its formative period dramatic representation is productive; it is these growing pains which count in education. When 
the climax of growth is reached there is a rapid and steady degeneration.

"The term "dramatic play" is misleading; one should say "dramatic expression" or "dramatic interpretation," which are more inclusive, and have to do with the means, not the end. Dramatic interpretation may be applied to all the work of the classroom, - a vital spark of life dropped into the lap of formalism and routine. All work which is imaginative, constructive, and vivid is dramatic. It is this interpretation of the drama, rather than its more limited phase of dramatic play, which needs to find its way into the schools. I need not, therefore, necessarily give a play to use dramatic interpretation in school work, but I do need to present geography, history, and even mathematics dramatically. I must infuse an emotional quality into the ideas to be instilled, for emotion is the connecting link between facts and life. It is not only necessary that I know a fact, but I must feel it in its relation to humanity.

Dramatic representation is instinctive, and instincts dominate childhood. Through such interpretation the child touches heights and depths which otherwise might never enter into his experience. Life becomes larger as he learns to lay aside his own limitations and put himself in the other man's place. He need not wait to enlist in the army to become a soldier, nor carry a real gun to acquire a martial step. He need not do wrong himself in order to know the remorse of wrongdoing. The child is egoistic, and that which he understands must bear an intimate and personal relation. Just as he must take into his hands the concrete thing he studies, and by physical contact understand it, so, to understand thought, emotion, character, he must assimilate them, lose himself in them, and become for the time being that thing which he interprets. 
The child tries on and throws off moods and emotions easily, for his young body is alert, sensitive, and supple. It is not hampered by the fixed habits of thought and feeling which make the adult impervious to suggestion and variation. Dramatic representation recognizes this, and involves the use of the child's whole body; without specialization, amœbalike, he takes in impressions with every part of it. The child is undifferentiated emotionally. He does not smile when he is glad, but fairly dances with joy. He does not shed a few tears when he is unhappy, but kicks and shakes with his grief. The opportunity to make use of his whole body in the expression of his feeling, which he is compelled to do in dramatic interpretation, will serve to equalize and conserve his moral strength. Emotional expression, although dependent upon instinct, must not be left to chance. Instinct and emotion are as capable of organization as motor and mental processes, but not through didactic preseription. Here more than anywhere else organization and education must go on within the pupil himself through the illuminating process of self-expression, passing from its fundamental to accessory phases.

Just as drawing and clay modeling bring form into relief and necessitate clear images, so dramatic work brings character into consciousness, making mood, motive, cause and effect, stand out in relative proportion. Such expression brings to the emotional life what travel and study bring to the intellectual.

Dramatic work also organizes the child's thinking. The simple and imperfect images of childhood are vivified and crystallized by being transformed into the movements which express them, and a child emerges from dramatic representation fortified in his mental imagery. Action and imitation are potent factors in the education of children, and 
the dramatic work makes it possible to secure purposeful activity, as well as to organize and limit that which one would have the child imitate.

Dramatic work enriches experience, relieves formality, reduces restlessness, and establishes a reciprocal attitude between teacher and pupil. It vitalizes the reading, illuminates geography and history, and gives motive and utility to the handwork. It chases out self-consciousness and gives an incentive to public speaking and impromptu address. It organizes the imagination; seizes upon essentials through the enforced limitations of time and space, and sets free a sense of humor out of which will grow a sympathetic philosophy of life. Dramatic expression invites a copious vocabulary and lends significance to the school library. A book on manners and customs will be little used until the child needs the information which it contains to portray some character.

Dramatic representation of historical subjects opens history to the girls. History becomes not only the story of some great man's life, but the portrayal of the lives of a people, - the account of the struggles and victories of an epoch in which women figured and lent significant help.

A few suggestions as to the method of presentation may not be out of place. The interest of the work grows out of certain fundamental instincts of childhood, - imitation, construction, and motor activity. Unless the manner of calling these instincts into play is well organized, the whole value of the art is lost. Dramatic play in the early grades means the hardest kind of thinking and a most definite creative effort. The moment that it degenerates into superficial play and noisy representation it ceases to belong to the school period and has no right to the precious school hours. One test of the worth of dramatic play in the 
school is the effect which it has upon the general discipline and conduct of the room. As soon as dramatic play leads to disorganization the teacher may be sure that she needs to look into her methods. If the work is presented with the proper forethought and planning, it becomes the prop of discipline. Boys and girls whom it has been impossible to control in any other way have been led to obedience and a sense of responsibility by coopperation in the dramatic work. One small boy of our acquaintance, upon whose saucy head every form of penalty had been laid without effect, was aroused to earnest effort and good conduct by being allowed to take part in the dramatic work when he had fulfilled his other obligations, and by being denied this privilege when he had not. It was he who thought of an ingenious way of escaping the wolf when he played the story of "The Three Little Pigs." The wolf was in hot pursuit, and the audience trembled for the little pig till he suddenly seized the waste-paper basket, curled up in it, and rolled to his house in safety.

First, then, the failure of the work in its early stages is due to a lack of organization. Dramatic work should be begun in the kindergarten, and should proceed with increasing complexity through the grades. It should have its initial start in the simplest representation, and should be well within the grasp of the players. The simplest form of representations is pantomime, and this may be begun in connection with the reading lessons. For instance, one child may illustrate some simple action in pantomime, which another may interpret in a simple sentence to be written on the blackboard. When the board is full of such sentences the review of the reading becomes very simple; every child is eager to choose a sentence, and without telling which one, to illustrate it, while another points to the sentence 
describing the action. Such a plan necessitates the rereading of all the sentences by each member of the class, and the words are being given significance by the accompanying illustration. For instance, the following sentences might result: "I am chopping wood"; "I am washing dishes"; "I am ironing my clothes"; "I am riding my horse"; "I am flying my kite"; "I am watering the flowers." A whole vocabulary of words may be learned and reviewed with the closest application on the part of the children.

This pantomime may be followed by simple character sketches, in which a child may portray quickly, and with both gesture and language, a father, a mother, an old witch, a brownie, a newspaper boy, a blacksmith, a school-teacher. These should be bold outline sketches, without the necessity of memorizing anything and with freedom to invent, construct, and choose. The child uses his body to portray the characters, adding words as they help to make the portrayal more vivid and more interesting. Next, animals may be represented, taking care to choose those which have striking characteristics, as the lion, the polar bear, the elephant. In every part of the work the children are doing their own thinking, recalling and organizing their own experiences, eliminating the indefinite, and seizing upon the salient and important traits. In proportion as the representation is vivid and true to life, will the player gain the coöperation and sympathy of his audience. These bits of portrayal evoke interesting comments on the part of the class, and lead to requests for further information about the animals or characters brought before them. Very soon the class will not be content with one player. The boy who is trying to represent the monkey will suggest that he have a hand-organ man; the hen will want chickens; and the scene will grow naturally and easily without dictation from the teacher. 
The next step might be the portrayal of moods. 'The children will choose such subjects as a frightened girl, a lost child, a lazy boy, a happy child, a tardy boy, a soldier on duty, a rheumatic old lady. It is interesting to see how the children grow in power of representation and suggestion, and how naturally language begins to be the necessary accompaniment of gesture in a satisfactory representation. The language of the children will be pictorial and full of unexpected turns and phrases. At this stage of the work it will be found helpful to put a screen between the player and the class. Such a device adds a little mystery to the play and throws the burden of interpretation upon the voice. The audience must rely upon the emotional quality of the voice in order to interpret the character. For instance, a child says, "I do not want to go out to play." It depends entirely upon the tone of voice in which the words are said whether the class is to describe the character as a sick boy, a tired boy, or a sulky boy. There is a great opportunity here to suggest the use of new and better words, for the class will see the need of clear, descriptive, and vivid language. 'The effect that such work may have upon voice culture is most significant. 'The artificiality of the tone quality acquired by our formal reading is absolutely impossible when the feeling or desire to express precedes the language used.

Tableaux organized by the children and representing phases of school life, home life, historical scenes, will be found most effective. The emphasis here is mainly upon the position and ease of the body, and the expression of the face. Children learn a degree of self-control by such adjustment which reflects itself in other lines of work. The child who is conscious of himself, and who is not losing himself in the representation of the present moment, very soon meets the 
criticism of the class. Invite such criticism, and by keeping it impersonal and to the point, train the children in the formation of just, constructive eriticisms. The opportunity which such work offers for the questions, "Why do you think so?" "How would you make the work better?" shonld not be omitted, for it means that later that boy or girl will not learn lessons by rote without question or reasoning. The tableaux chosen should spring from the school work, or represent scenes which are vividly present to the children, - The School Garden, A Reading Lesson, The Playground, A Pienic in the Woods; or more serious subjects, - The Eskimos at Work, Hiawatha and his Brothers, The Pilgrims' Sunday, etc. Many of the national holidays lend themselves to tableau representations.

After the experience gained by the representation of such character sketches and moods, the children will be ready to undertake stories with simple plot. The beginning of plot will be found in the stories of Mother Goose. The value of the Mother Goose representations lies chiefly in the simplicity of plot, for unless the story is exceedingly simple and easily remembered, the children cannot form a mental picture vivid enough to portray. Children are ready to listen to many beantiful stories which they could not possibly play. They are able to get general impressions and suggestions which are invaluable from stories whose plot and incidents they could not put into form. But when a child is asked to represent a character, or to play a series of incidents, they must be as familiar as his own name, so that he may lose himself in the representation, and not spend his energy trying to recall what to do next. It is because the stories are not sufficiently familiar or sufficiently organized that the children frequently show a lack of enthusiasm in their representation. A young teacher 
recently said, "The children I have must be different from others; thiey do not respond to the dramatic work, but stand up awkwardly with nothing to say." Upon investigation it was found that the little people in question had been asked to take part in stories which had only been told them once, and which were too complex for them to handle. Of course they had nothing to say. It was like exploring a new country, and there was no familiar path upon which to walk. They had enjoyed the stories, and undoubtedly gained impressions, but playing a story is like drawing a diagram: every detail must be clear; a hazy, indefinite impression cannot be put into tangible form. But such difficulties only testify to the value of the work; we are working for definite images, and perfect mental control; the dramatic work makes it possible to find out just how clear children's images are, and to set them right in their thinking. When the simple stories of Mother Goose were offered to the children referred to, and they were given a chance to represent something which was vividly pictorial, they became the most enthusiastic workers, showing a desire to dramatize everything in which they were interested.

Children should not be asked to memorize parts. Such work is not constructive or creative, and therefore of little value. If dramatizing is memorizing, then let the children store their minds with beautiful bits of poetry, exquisite in their form and feeling. Dramatic work is imaginative interpretation, and therefore the burden must rest upon the child himself.

In taking up the dramatization of stories, if a plan of work is followed, there will be a gradual transition from pantomime, tableaux, and portrayal of mood, to dialogues and easy dramatic plots. The story chosen should have abundant action, and divide itself naturally into consecutive 
parts. The teacher should have a definite synopsis of the story clearly in mind, - a beginning, a middle, and an end. She should, by discussion with the children, divide the story into these parts, so that the sequence of events will be held clearly in mind. A skeleton of the story may be written on the blackboard, so that the unnecessary and nonrepresentable parts may be eliminated before there is any attempt to portray them. It should be possible to write in two or three sentences a synopsis of a story suitable for little children to play. In the process of organization which precedes the playing the teacher may say to the children, "When the story opens, in Part One, who is present?" She may then name and write these characters on the board. "Who is the first person to appear?" "What is she doing when the story opens?" "What does she look like?" With simple questioning the story is recalled, and reviewed with enthusiasm and motive. "If you were the Old Woman in the Shoe [or whatever character the child is to play], what would you do when the story opens?" Get several children to try, and then ask the class which was the best Old Woman. They will give fine points of interpretation, mentioning clear voice, face to the audience, looked like the picture in the book, etc. In such a preparation lies the value of the work. The story is constructively organized, and all the class is working together. The teacher must, however, enter into the work. She must be expressive and suggestive. For instance, some child portrays the wolf in "Little Red Riding Hood." Perhaps he is not very expressive, and his representation is not vivid. Here is the teacher's opportunity to throw the work open to the class, and to ask some one else: "Were you very much afraid of that wolf?" "Well, what could you do to make us more afraid?" "How could you make yourself look 


\section{PEDAGOGY OF THE PRIMARY SCHOOL}

more like a wolf?" "Can you think of anything to say that will make the story better?" The children will be only too happy to volunteer suggestions, and in this way the work is kept a growing conception. The analysis of the story is constructive, not destructive, and is based upon the children's own experience and imagination. The work is kept childlike, creative, and original.

As the stories are played the children become lost in the characters and forget all question of sex. When some big, overgrown boy asks naïvely, "May I be the mother?" let him, without comment. Character and action are sexless, and it is interpretation of these that interests the children. They are, for the time being, not boys and girls, but fathers, mothers, fairies, witches, and gnomes. The children are simply projecting character upon a screen, that they may see it more clearly.

Sometimes in giving plays the children will suggest other parts ; for instance, some child will say, "Did n't the boy in the story have a father too?" or "Was there only one person at home when the fairy came?" When the suggestions are natural, and do not interfere with the construction of the story, there is no reason why the children should not have the added pleasure of playing another part. They will frequently make very suggestive additions which increase the attractiveness of the play.

It is well to allow a child to take the part which seems to appeal to him, but there is also a chance to encourage helpful coöperation. The children may learn to hold the success of the play above personal gratification. A bashful child should never be forced to take part in the plays. If he is left to himself, he will soon ask for a part. 'The most timid child rarely withholds himself more than a few days, and by a little tactful planning on the part of 
the teacher characters will be assigned where they will do the most good.

As to the question of costume, some slight addition to the ordinary dress will be found to be more suggestive than an elaborate make-up. A cap, a sword, a drum, a wand, a walking stick, a shawl, a doll, an apron, will give the needed touch. The children should be allowed to make these bits of costume during the handwork period. A general property box should be kept in the room and its contents added to gradually in the most economical way. A "Mystery House" for puppet shows might also be built.

The puppet play is a lost art which the primary schools could well restore to childhood. The wonderful educational and recreational possibilities of the puppet are as yet untouched. Children take a keen delight in miniature reproductions of life. They are attracted and compelled to interest by moving objects, which they immediately endow with life. The puppet play is irresistibly fascinating to children because it combines motion with a suggestive reproduction of the human form, voice, and mimic gesture. The tiny, grotesque figures which look up from behind the curtain are so crude and flexible that each child may give free play to his imagination and endow these miniature men with a personality in keeping with his own temperament and experience. The curtain helps, too, by adding an air of mystery to the source from which these tiny people come, and their coming and going is so humorously abrupt that every child attends, while the elemental emotions of wonder, curiosity, imitation, fear, love, joy, humor, are aroused in a crude form of drama which is profoundly childlike.

The puppet show should be revived along with folk songs and traditional games, for "it has been acted and written and sung into the lives of the great and lowly, 
the rich and poor, of all climes and nationalities." The play was started by Silvio Fiorillo before the vintagers of southern Italy in 1640. In an article on "The Most Popular Play in the World," by Ernest Russell (Outing, January, 1908), we read, "In England the puppet play followed the mystery plays," and was used as "a side show for circuses, a traveling amusement, an entertainment in the convent, on the street, and at evening gatherings." These puppet shows have been in operation nearly three hundred years and appear as Punch in England and America, Punchinello in Italy, Polichinelle in France, Hanswurst in Germany, and Pickelhering in Holland. Even the sternest of us must admit that those fundamental emotional experiences which have appealed through long ages to the folk soul find a subtle response in onr own nervous make-up. The tears and laughter of the race start from our own eyes, and the puppet show will continue to delight all children till their very instincts decay.

Aside from the delight, the puppet show may be of pedagogical utility to the elementary school. It may be used to advantage in the reproduction of stories, dialogues, and current events which it is desirable to emphasize. The reproduction is so simple that the children may work up programs of their own. This will encourage constructive thinking and the use of good English. The children can easily make all the paraphernalia needed, for the construction of the puppets, curtains, etc. is quite within their manual skill and will furnish excellent opportunities for the handwork. Pumpkin, gourd, or almost any rotund vegetable lends itself to puppet life. Take the most commonplace potato, make a crude face on it, wrap a bit of eloth about it, insert the finger in a hole made in one end, and lo, the potato becomes fascinatingly human and will bow and 


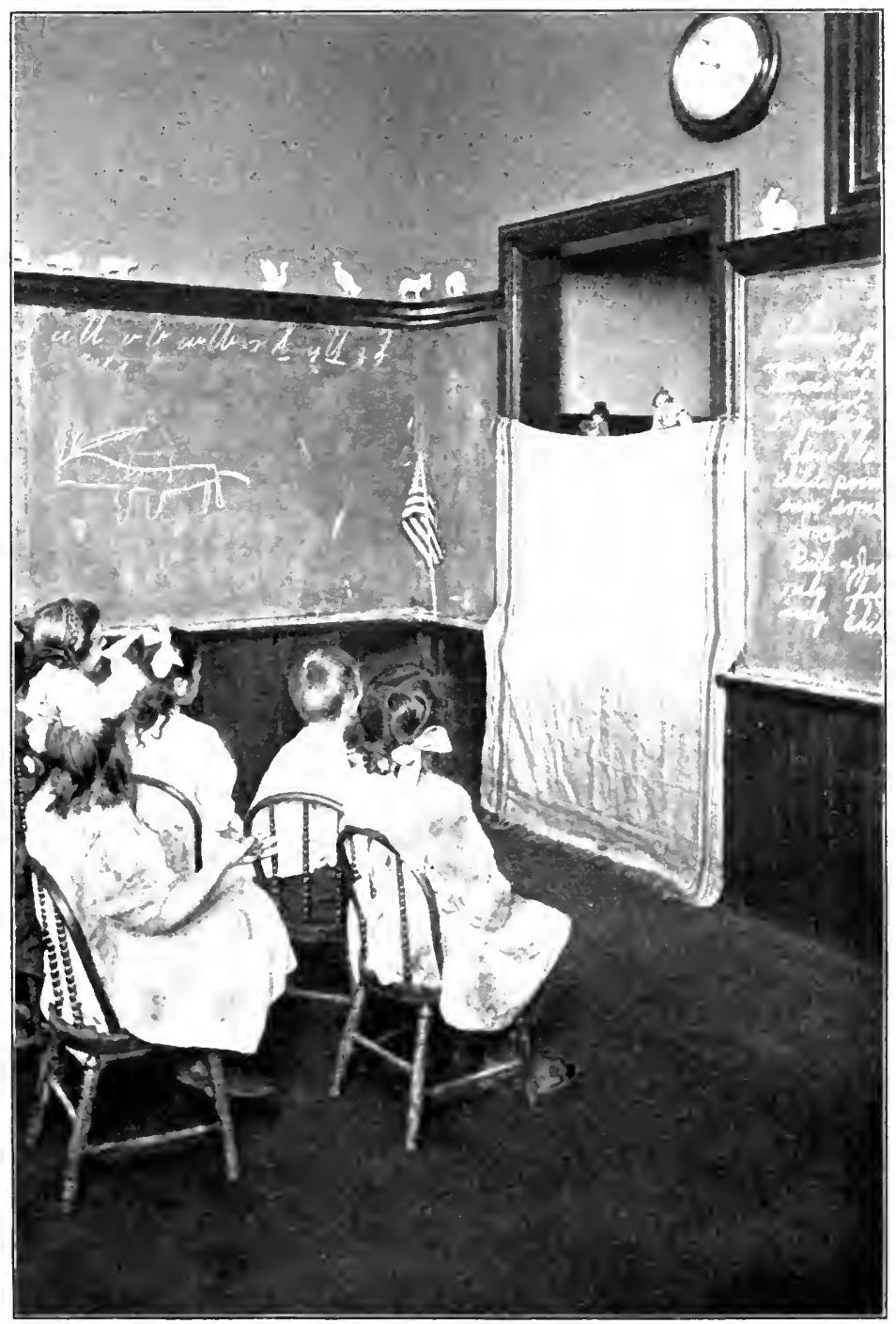

Fig. 31. A Primar Prppet Play 
jig and talk at your own discretion! The little group who are so intently looking and listening in the illustration give evidence of the power of the puppet play to command concentrated attention.

It will be found that the success of all dramatic work depends upon the degree of organization with which the stories are attacked, and the freedom and spontaneity with which the children are encouraged to interpret character and action. The playing of the stories can be made the most serious work of the day, and there are endless opportunities for reading, writing, spelling, and language lessons in connection with it. The word "play" has frightened a great many educators, but we are beginning to realize that the play spirit is the art spirit, and that the hardest work is often the most delightful. Play with little children is a mood, a method of attack, and has little to do with energy or effort, except that a child puts forth his best effort when he is in a playful, happy, creative mood. 


\section{CHAPTER XI}

\section{PHONICS AND SPEECH}

The recent science of experimental phonetics as represented by Dr. E. W. Scripture introduces a new theory of voice production. His method of curing stutterers and stammerers reënforces the necessity for intelligent care and control of children's voices during the early school period. It emphasizes the prevention of the formation of bad habits of speech, so that their cure will be made unnecessary.

According to this theory of voice production " the larynx, containing the two vocal lips, which open and shut by compression, omits a series of puffs of air so fast that the puffs make a tone. The puffs from the larynx strike a blow on the air of the vocal cavities, chest, nose, and throat, etc., and set it in vibration. These vocal cavities have soft walls and are adjusted to certain tones for each vowel. The vibrations correspond to the sizes and shapes of the cavities." "The pitch of the laryngeal tone is determined by the degree of tension of the vocal cords. To vary the pitch the laryngeal muscles must be freely and delicately poised and must act readily and accurately." These cords, says Scripture, "must be trained to emit such forms of explosion as will produce the best effect upon the ear."

The theory of voice production once established, and the necessity for training the vocal cords to emit sounds pleasurable to the ear admitted, the next question is, "What is the most economical way to secure a well-trained speaking voice to the young children we are helping to educate?" 
Dr. Scripture gives three causes of speech defect: (1) excessive innervation of the speech organs; (2) deficient innervation of the speech organs, which he terms subenergetic phonation; and (3) defects in the speech organs themselves.

There is no greater educational sin of the present clay than the absolute disregard which we show in our schools to the quality and beauty of the speaking voice. The average classroom is as offensive to the ear as it sometimes is to the nose, and the average teacher is equally insensible to both. We all recognize that a good, clean-cut, expressive voice is a great asset and goes far toward personal power, and yet we are turning out armies of young people to whom it is unpleasant to listen. We are as a nation famous for a flat, nasal, sluggish tone which robs the best language of its force. The evolution of the human voice marks a victory for man ; his voice is the instrument of power which places him above the brute. Shall we then be so concerned with the accumulation of facts that we disregard our birthright and become content with signs and grunts? The schools are zealously teaching the boy to write, long before he needs that technical power, and are forgetting how much more dependent that boy is upon the control and convincing power of his speaking voice.

When considering the problem of the value of phonetic drill in the school, its use as a mere aid to reading may be utterly disregarded. The purpose of phonetic drill has a deeper and more significant meaning. It is of inestimable value for four other reasons: (1) ear training, (2) clear enunciation, (3) breath control, (4) the discovery and correction of speech defects.

The cases of superenergetic phonation, or excessive innervation of the speech organs, are comparatively few in 
the schools. The process of cure involves gaining control over each one of the vocal organs, and in serious cases needs the attention of a specialist. But the problem with which phonetic drill has to do is that of subenergetic phonation, common to nine tenths of the pupils. We all know that children with perfectly healthy vocal machinery liave unpleasant voices. Why? Because they constantly hear unpleasant tones; because their standards are low, and there is no ideal of beauty of tone set for them to imitate. Phonetic drill, then, should awaken an ear conscience, and no teacher should be permitted to victimize a whole roomful of children by pouring into their ears a volume of ugly tone. One of her requirements should be a good, clear, expressive speaking voice. Children are more sensitive and more easily reached through the ear than in any other way, and the secret of a teacher's influence is often the flexibility and beauty of her voice.

The voice reflects the character and habitual attitude of the individual. A pure tone is dependent upon health, breath control, emotional attitude, imitation, and the physical formation of the speech organs. We are forced to admit, then, that we may not leave the voice to a natural development, but that education must step in with its ounce of prevention. One must preserve the power of deep breathing, and secure flexibility of tongue, jaws, and lips, etc., in order to make the emission of a pure, clear tone possible. Just as the careful and frequent cleaning of the teeth prevents decay and preserves the natural mouth, so breath control and flexibility keep the vocal organs in trim to do their work smoothly and effectively.

But it is asked: "Will not a child breathe naturally without instruction? Why make him conseious of his organs? Nature will take care to regulate them." Nature 
is already overburdened in this artificial life we lead. The ill-ventilated room is a destroyer of deep breathing. The system is protected against impurity by the child's refusal to let the foul air into the lungs except in sufficient quantities to preserve life. A kind of panting is substituted for natural breathing, and the necessary function of inhalation and expansion is inhibited.

Now the voice is dependent upon breath control. The vowels which we use are made by sustained open columns of air; the consonants - the messengers of the sound world to carry the vowels to their destination - are made by obstructing these columns of air with the lips, tongue, teeth, etc. The lips, tongue, and teeth of the individual child may be in good order, but unless he can control the column of air, they are of little use in securing a good clear speaking voice. Before orderly, even speech is possible, there must be a liberal supply of air drawn into the lungs, and the speaker must know how to control its output.

Another cause for subenergetic phonation is the lack of emotional tone, enthusiasm, and vigor. We frequently find a fresh young voice in an old body, and the voice will remain fresh, clear, buoyant, so long as it has behind it such an attitude toward life. The human voice is flexible in proportion as it identifies itself with human feeling. The indifferent, careless, joyless individual expresses his colorless experiences in a flat, sluggish tone. The schools with their formalism and dull repetition are creating a peculiar schoolroom tone which is untidy, nasal, and spiritless. The artificial reading and concert work of the early grades pitch the voices of our young into a loud monotone to be molded into a habitual and unconscious drawl in the upper grades. We are learning that free lunches and medical inspection, by raising the physical tone of the children in the grades, 
increase the volume and improve the quality of the voice, but we must now learn that feeling and mood are at the basis of melody and flexibility.

By means of delicate instruments the voice of a speaker or singer can be caught by the phonograph or the gramophone, and then transferred to strips of paper for closer study, in the form of visible vibrations which are represented by curves. Experiment has shown that there are distinct

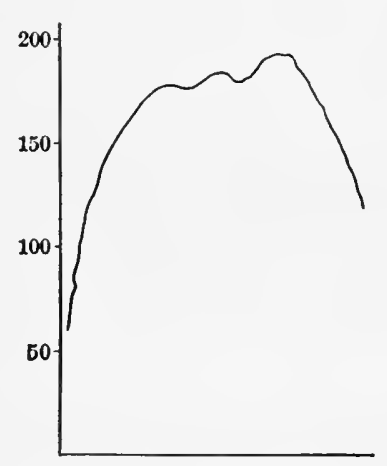

Fig. 32. Melody Plot for "OH!" SPOKEX sORROWFULLY

(After Scripture)

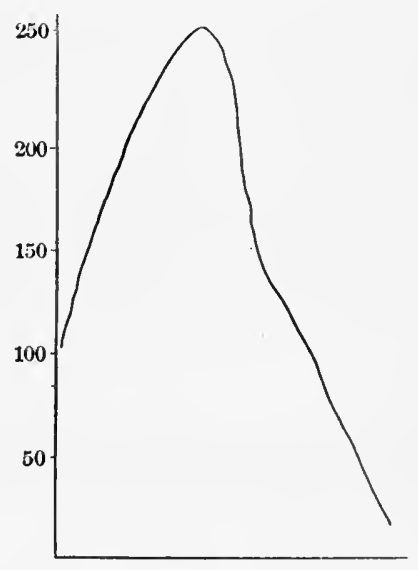

Fig. 33. Melody Plot for "OH!" SPOKEN ADMLINGLY

modifications of these speech curves dependent upon the emotion of the speaker. There is what Dr. Scripture calls a "melody plot" in every vocal expression, even in the utterance of a simple sound like "Oh!" and this plot varies decidedly with each emotion (Figs. 32 and 33).

The "melody cure" is being used to correct stammering and stuttering. "By putting melody and flexibility, rise and fall, into the vocal utterance of persons with such speech defects, new speech habits are formed, ease and fluency are acquired, and the old compulsive fear which 
inhibits speech and eramps the muscles of the larynx is driven out." The stutterer speaks in a characteristic monotonous manner, represented in Fig. 34. He is cured when he learns to say "Good morning!" with melodious modulation, as shown in Fig. 35.

This melody idea should be made use of in phonetic drills to establish free, flexible tones which produce pleasant effects upon the ear. Children love to play "echo"; the teacher says a phrase, in any form or intonation she chooses, and the children give it back in soft, smooth, echo fashion, preserving the same inflection.. She can give three or four interpretations to such a simple sentence as "Come in." That is, she may say "Come in" in many moods. It may

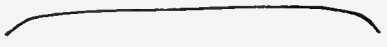

good $\operatorname{morn}$ ing

Fig. 34. Moxotoxy of the Stutterer's Volce

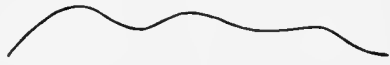

good morn ing!

Fig. 35. Fluctuatixg Melody in the Normal Voice

represent a call to people in the distance, a command, a hospitable invitation, joy, excitement, surprise, - thus giving the class the opportunity for unconscions imitation of melodious, flexible speech. The device is a simple one, but gives the incentive for close attention and precise imitation in a happy, childlike mood.

The problem of ear training and voice culture is a serious one. The majority of our public-school children have never heard the English language in its purity. They do not pronounce their $t$ 's and $d$ 's, nor make use of round, pure vowels; because they have never heard them; or because they have acquired a lazy habit of keeping the jaws rigid and of holding the teeth close together. The language conscience should be awakened in the lower grades, so that 
the children will stop their ears to an unpleasant speaking tone, as they will to the shrill whistle of a locomotive.

Voice culture must come through the ear, and it can be brought about only by unconscious imitation of pure sound, presented in a playful, suggestive way. Primary children are in an imitative, playful, language-building period, and therefore such work in voice culture belongs to the earlier grades. This training is a thousand times more valuable than the conscious analysis of words. It is, after all, oral composition, and oral composition is what we need, - face-to-face, direct, and intelligent communication of thought in a clear, natural tone. The distressing quantity of written work, out of proportion in the first grade and fairly swamping our normal and high schools, utterly disregards the crying need of our young people for acceptable oral presentation. There should be a reformation throughout the elementary school which would establish a belief that the power to talk well must precede the power to write well.

Let us admit, then, that there are serious local causes for the unpleasant voices characteristic of our land, and let phonetic drill help to eliminate them. In every school where there is artificial reading, and lack of joy, interest, and emotional response; where teachers with colorless voices compel harmful imitation, and absence of good fresh air prevents wholesome breathing; where concert work fostering loudness, not quality of tone, prevails, - there will be found the natural causes for grave offenses against pure tone quality and clear enumciation.

Children are instinctively interested in sound. They amuse themselves when alone by repeating over and over again sounds which interest them, irrespective of their meaning. Why not lay hold of this instinctive tendency 
to educate the sound sense as you do the color or number sense? If one may not have a separate period for phonetic drill, use the game period for exercises like the following.

Give the children directions to do certain things; as, "Close the door," "Open the dcsk," etc., — using the lips only and without uttering a sound. What will happen? Every eye will be focused upon the teacher's mouth, so that the children will begin to see how the rowels and consonants which they hear are made. Unconscious imitation will set in and help them to place their own vocal organs in proper position when they in turn are permitted to give the directions. For instance, enunciating clearly but without vocalization, say, "Touch your head," "Clasp your hands," "Open your mouth," etc. Some of the children will for the first time in their lives realize that " sit" has a $t$ at the end of it, " head" a $d$; for they have never heard the words except in a careless, sluring fashion.

Again, children love to imitate sounds, and there are many which they hear every day which can be made use of in a game. The child who plays is to impersonate some animal or thing, and may make known what he is only by some characteristic sound. When you say "Who and what are you," he will reply, moo, or coo, or sss, sh, ch, etc., meaning "cow," "dove," "snake," "skyrocket," "engine." Now comes the teacher's opportunity to introduce new and difficult sounds which require prolonged vowel control, quick, direct consonant drill, and sustained breathing. This work may grow in complexity until the repetition of difficult bits of rime and alliteration are mastered, and failures of speech control in individual children noted, without undue consciousness. Playing "echo," as described above, is another device which may be used in this connection. 
Work of this character may be followed by a session with "Mother Goose." Much of the charm of "Mother Goose" is due to its abundant rime. Children listen attentively to recurring accent, and begin to get a feeling for the rhythm of language. Train the children to listen for and recognize sounds that are alike. "Jack and Jill went up the hill; Jack fell down and broke his crown." This exercise is at first merely for the recognition of rimes, and the children may hold up their hands when they hear words that sound alike. The next step is to let the children do the riming. "I am thinking of a word that sounds like rake, - what do you think of?" Place the words presented by the children under one another, so that they will see that the initial consonant makes the difference in the meaning, and that the body of the words is constant. Now these words may be pronounced in a whisper quickly, with the teacher as a morlel to imitate. If the game spirit is preserved, and flexibility and response set at a premium, the results are excellent.

Consonants should not be separated from words and vocalized. Such an exercise gives a child a very false idea of phonetic values. There is no such thing in the English language as $d u h, p u h, m u h,-$ as $d$, and $p$, and $m$ are ordinarily pronounced. Consonants mean merely the placing of the vocal organs in position. They are the triggers of speech; set the trigger, and when it falls it will release the vowel and send it to its journey's end. For consonant drill let the children imitate the position of the teacher's vocal organs, and quickly say a word beginning with the consonant the symbol of which has been previously written on the board. A long list, as "bad," "boy," "beg," "burst," "big," "body," "bean," "baby," will be mentionerl by the children, who will be made conscious of the fact that all these 
words begin with $b$, and that it is necessary to place the vocal organs in a certain position before it is possible to say words that do begin with $b$. 'The consonants are absolutely disfigured by being separated from the vowels which they emphasize and vocalize. The analysis of words into selfconscious, separate sounds will undoubtedly bring on inhibition and speech defects. A recent report of the public schools of Boston calls artificial phonetic instruction the breeding ground of stuttering and stammering. The beauty of speech lies in a smoothness, fluidity, and lack of hesitation which cannot be acquired by analysis, but by unconscious and skillful imitation of pure words.

In the riming which has been suggested and the arrangement of words with similar endings in columns, the necessary aid to reading ean be given and yet the emphasis be laid upon melody and sound values. All the word endingsas end, and, ind, ate, ite, ake, ight - may be taught in this way, serving the double purpose of insuring the quick recognition of words and the opportunity for effective sound drill. 'The words which end alike may be put into short sentences vibrating with action and full of interpretive interest, so that the oral reproduction of them will be full of melody and flexibility. The learning of word endings should, however, be merely an accompaniment of phonetic drill, and not an end in itself. The purpose of phonics in the schools is not to reduce reading to a mechanical process, but to serve as a means of voice culture.

'The compiling of dictionaries in connection with the phonetic work is an interesting and special help in reading and spelling. Make a book in the liandwork period; put at the top of each page one of these endings, - and, end, ate, etc.; let the children enter words studied according to their respective endings. Sound values will soon 
become conscious to the children without any harmful analysis of words.

Perhaps a few suggestions for improving breath control will not be out of place:

Let the children try to blow out an imaginary candle. They will take a natural breath and then send it out in one explosive effort. The imaginary candle which the teacher holds in her hand in front of the class may be held at different distances, so that the amount of breath taken into the body will be increased.

Let them play that they hold a four-o'clock in their hands, and try to blow all the feathery down off at one expiration.

They may play that they hold pin wheels in their hands, and in order to keep them going smoothly round and round, must take a long breath and then send it out slowly and evenly. This even control of the breath is exactly what is needed in effective speech, and this simple exercise offers training in breath control with a motive and without making speech self-conscious.

To get the same exercise, the children will enjoy playing that there is a feather floating in the air just above their heads, and they must keep it up in the air by blowing upon it.

To imitate a tired dog panting gives an opportunity for a succession of explosive breaths, decreasing in volume until the breath drawn in has been exhausted.

Such devices may sound very simple to those who arc afraid of the word "play" in the classroom, but to play that a thing is so means to imagine it so, and children's imaginations are so active and vigorous that there is nothing forced or conscious in the exercises suggested. If one tries to lead the children to take a long, deep breath simply by saying in a formal way, "Now take a long breath," the 
children swell up like little porpoises, and the distention is entirely forced, without developing the natural control of breath. It is surprising to see how few children expand their lungs naturally, or make use of their proper lung capacity in breathing. Such failure is due, as has been suggested, to the artificial conditions in the schools and in the homes, and it is a failure which needs the attention of every intelligent worker in the field of education.

These phonetic exercises may be termed technical, but surely they are far less so than the technicalities of reading and writing which are being forced without hesitation upon the children in the primary school. Technicalities of pure speech should precede those of the written or printed page.

There are good opportunities for preventive work here. Hundrerls of thousands of youths and adults are now suffering from serious speech defects, which originated in childhood and were then most easily remediable. Primary teachers are dealing with this childhood age when the speech habits are still plastic. They can do something to prevent the serious defects in the few, and still more to correct in the many the milder defects of slurring and deforming vowels and consonants. With the speaking voice, as with many other things, there is a normal standard, which is distinctly above the prevailing average.

Thought, whether written or spoken, depends upon emotion, or feeling, and takes on rhythmical form in its expression. Little children are sensitive to rhythm, and therefore the habits of easy, rhythmical, flowing speech should be established during the instinctive, language-building period of child life. The schools should not consume the time of the children by preparing them for some distant future when they will need to read and write, but should fit them 
for a happy present in which they need, every hour that they live, to make use of their voices in natural communication with their neighbors. Children are thinking all the time, and if oral expression of thought were made attractive and resthetic, there would be more interest in reading recorded thought. Most people would learn to read, even if the schools were abandoned; and if they waited to attack the reading problem until they were mature, they would probably read more fluently and intelligently. Speech is absolutely necessary from babyhood on, and children will imitate what they hear. Speech habits are bound to be formed at an early day, and if they are incorrect ones, it will be almost impossible to break them. No individual, in whatever walk of life, can afford to be deprived of the power and influence which go with a strong, clear speaking voice, full of melody and flexibility. 


\section{CHAPTER XII}

\section{L.ANGUAGE}

Language cannot be taught, but must be evoked. Speech is the incarnation of feeling and thought. The theme and melody of a bit of music are present in the composer's mind before he communicates them by means of notation. 'The notes are only a clumsy representation of the artist's more intimate ideas and feelings. So it is with words, which are merely the signs of previously conceived ideas. Ideas spring from experience; the more varied the experience the larger the stock of usable ideas.

Language grows out of the social instinct, and where this instinct is dead, as it is in most schools, language too will be lifeless. When there is desire, speech comes naturally, but a negative, formal schoohroom attitude stifles desire. Man has a language capacity, but life and school must provide an opportunity for its development.

The language of a nation is constantly growing, not by any fixed laws of increase, but in sympathy with new conditions. New objects, new discoveries, new ideas, demand new words. The language of a child is like that of a nation. The listless, idle, overdocile child is not creating new images which will ery for words to clothe them. Little children are in the language-making period. They have keen ears to catch fine intonations, and sharp eyes with which to observe new facts; and yet language in the primary grades is usually as formal as the orthodox butler, and as unorganized as the tin man in the "Wizard of Oz." Language is 
a tool which must not only be preserved from rust, but must be sharpened to do its work with precision and effect, that thought may be expressed with freedom, clearness, and correctness.

Children are poets, and the stimulus they need for the development of poetic expression is direct contact with nature. They need to come upon surprises, unexpected likenesses, and alluring lights and shadows. Then language takes on vividness and beauty. Outdoor life stirs the children intellectually too, and by constantly presenting problems for solution it creates a fund of new ideas. These problems are to be solved in terms of comparison and contrast which arise ont of live conditions and concrete experiences. Out of this first-hand contact will come nouns, adjectives, and apt phrases. The child of the outdoors will naturally say "as gay as a dandelion," "as black as a cloud "; or, as a little five-year-old boy said when he looked at his uncle's rough, mottled gray suit, "That makes you look like a horned toad."

Language owes much to the startling beauty of nature, and children are more alive to the wonder, mystery, and newness of life than any one else. They are ready to accumulate the impressions, the raw material out of which they will fashion their happiest conceptions. Unconsciously the beauty and suggestion of life surges in upon them, and their hearts are overflowing with joy. From a full heart language is born. The morose and somber are silent, but the joyous needs must speak.

Children's vocabulary will grow naturally if they live in a suggestive environment. They should be allowed to hear the stroke of the hammer in the workshop, to feel the softness of the pussycat's coat, to see the blue of the sky, to taste the honey in the cups of the flowers, and to smell 
the pungent fall odors. The great Creator gave the child a voice, but it is a mere instrument of expression upon which experience, imagination, and joy must play. The strings of a harp will be silent without the stroke of the fingers, the voice without the push of desire.

Language lessons are frequently as ineffectual as our attempts to write to a friend with whom we have long been out of touch. What is there to say? - we have no words because we have no ideas which compel communication.

If you would foster the gift of language in the children, throw out the commonplace classroom expressions, and introduce variety and imagination into your own speech. Make the sensory life of the child a rich field from which he may glean striking comparisons, and stir his imagination to make use of them in attacking new ideas. Begin by changing your morning greeting, - find out in how many ways you can make the children welcome and begin the day ; feast their ears upon a variety of clear, musical English; give them "Mother Goose" with its quaint descriptions and humorous turns; let them listen to fairy tale and fable, that they may enlarge their vocabulary and make friends of new words.

Language is not speech alone; it is the communication of ideas. These may be communicated by drawing, modeling, and handwork, which should be kept in close relation to the language work. The dramatic play of the school is coming to the rescue of the language teacher also, for thought is communicated by gesture as well as by voice. Children are in the pantomime and gesture stage. They should be encouraged to put their bodies into action and the facial muscles into expressive use. Away with stolidity and orthodox position if you would have the children learn to talk well! 
If the children are allowed to talk naturally and freely, their language will be figurative, for personification is childlike. Children believe in their own fancies. Apparent likenesses and accidental associations are facts to them, which call out quaint and original expression. Children are impressionable and emotional, and their images are strong because they grow out of first-hand contact with life in its newness and mystery. See to it, then, that the school environment does not limit the contact of the children to prosaic books and ugly desks. Make room for the instinctive reactions toward elemental things, - earth, air, water, fire, - and their language will be vigorous and effective. Mere object teaching as a substitute for such intimate experiences as have been suggested is a delusion. The child who makes a formal sentence about an orange, a book, a pencil, held up before the group for inspection, is only giving the result of a perfunctory visual contact which is superficial and stultifying.

There are many types of successful language lessons, for which nature study, game life, and daily happenings furnish suggestive themes. These topics, however, must be presented in the form of problems, and developed by a few leading questions which quicken curiosity and stimulate thinking. The primary school is not nearly as progressive as it would have the world believe. Children are still memorizing symbols, only we have cunningly substituted words and sentences instead of syllables. It is the solution of problems that we need. Constructive thinking which makes some demand upon originality will develop personal power, but the dictated exercises and memory gems of the primary school call for neither constructive thinking nor imagination. The wordiness of the early grades accounts for the lack of initiative and power of individual attack which we complain of in the grammar school. 
Following are some suggestions for language work. The suggestions are simple and are intended to arouse better ones in the minds of those who read them.

1. Bring to school pictures which invite discussions and admit of original interpretation with interesting descriptive details. Do not choose pictures which merely represent the power of the artist's technique, but seize upon those which excite the imagination and invite speculation as to their meaning.

2. Make use of the study of mountain, park, seashore, or bit of local history. Allow the children to make imaginary trips to some of these favorite haunts. They may represent to the class where they have been by pantomime, or by telling in direct, descriptive sentences what they have seen or heard. Probably a child will choose a trip to the monntains as his topic. Perhaps he will say something like the following, which represents the description of a certain first-grade boy: "I took a trip one day. I went a long way from home. I took my dog and my father carried his gun. I saw trees and pretty rumning water. I waded in the cool water. I climbed up, up, up. Where do you think I went?" Did not that child gain power and discretion in the use of words? Is not this a more vital recitation than the repetition of something which he had learned by heart?

These guessing games are very useful and may be applied in many ways. Children love to deścribe things which they have seen, heard, or tonched. Sometimes the problem will be to describe a moving object, and they may choose a wagon hauling some load, a train coming into the station, or, as one child did, a fly crawling over the windowpane. Such exercises will result in the most graphic and interesting descriptions of animals, houses, trains, toys, 
fruits, flowers, and trees. You will be surprised at the originality shown, and the precision of expression gained. Of course the teacher must direct the work and lead the children to organize what they have to say, before appearing in front of the group, and to pick out the large, characteristic things to describe.

3. Keep the language lessons pictorial. This is very easily done when the children are drawing at the board. Give them the written symbols for the objects which they have drawn, and let them write these symbols under their pictures. After a little practice the younger children will pass from the mere enumeration of objects drawn, to descriptive sentences about the picture as a whole. They will write very terse and illuminating remarks, and through such experiences make an easy transition to the regular written work of the school.

4. Let the children read very simple stories; select the ones that can be illustrated. The reading should be done silently, and the sentences copied and illustrated. Children enjoy such a problem, and like to preserve the stories in bok form.

5. Language games for emphasizing correct forms of speech are, of course, recommended. The clanger is that the child who is saying "seen," "done," and "git" may be put through a series of games to teach him to say precociously, "It was not I." If language games are forced, they lose spontaneity and informality and miss their whole point, - which is to bring about a frequent, natural, and conversational use of certain necessary phrases. If these games are to be formal, it were better to drop them from the course of study, and insert the old technical instruction in the forms of speech which they have replaced. Language needs informal atmosphere. 
6. The children may be encouraged to make original stories to be written on the blackboard by the teacher and finally read by the class. New words will be frequently introduced, but they will be readily remembered because they are necessary to the idea which the children are trying to express. It is interesting and helpful to keep a list of these new words and to see that they are introduced again in reading lessons.

The following compositions were contributed by a class of A 1's, - the first after constructing an Indian village, and the second after a nature-study discussion.

We made an Indian Village.

We made a river in the village.

The river comes from the mountain.

It runs down the mountain.

It runs right in front of the Indian's wigwam.

The Indian likes the river.

The river brings fish to the Indian.

The river carries the Indian's canoe.

\section{II}

It digs in the sand.

It cannot climb, nor fly, nor run.

It walks very slowly.

It carries its house with it.

It draws its head and feet into its house.

Then it feels quite safe.

No, a turtle likes the water.

It is a tortoise.

It is interesting to note how the children who wrote these stories have reflected the primitive and poetic attitude toward nature. "The river carries the Indian's canoe, and brings fish to the Indian" are expressions of their conception of inanimate things, which they always endow with 
purpose and life. Surely.such reading material is far better than the formal, unchildlike, and unpoetical lessons to be found in the first readers. Children have more instinct for literature than the bookmen.

7. Some of the suggestions referred to in the account of dramatic work may be utilized with effect. Indeed, the children should not be expected during the language period to pass too quickly from the pantomime and pictorial stages of expression which make the transition to more difficult written work easy.

It is a simple matter to teach the little children correct written form from the very beginning. The endless opportunities to put work on the blackboard bring in the use of capital and punctuation marks so that the eye of the child may be made sensitive to form. The best time to teach the detail of written form is when the children contribute the original stories which have been referred to above. At these times the children give the natural phrasing which makes punctuation a necessity. They ask the questions and they see the need of question mark and period. When an exercise is taken from a book, and written on the board with the punctuation marks left out, the child has to waste time and energy wading through a meaningless jumble of words, and only the negative side of punctuation is emphasized. Moreover, the child is not in the mood of the paragraph, and so does not get the feeling for question mark or exclamation point. The work is much more constructive and helpful when the child punctuates as he writes, making punctuation the natural and habitual accompaniment of thought.

The child should talk well before he reads well, for oral expression is at the foundation of all intelligent reading. It is necessary, therefore, to interest the children in the 
simple, homely things in their environment. To accomplish this, assign definite problems of observation to particular children, and remember to ask for a three-minute report the following day. For instance, let a child observe a new building, or one in process of erection, and understand that he must come to school ready to tell all the items of interest in regard to it. The self-confidence and power aroused by the ability to tell a bit of information in a clear, direct way are invaluable. Even such a simple task requires intelligent organization which is constructive in character, and which is the very earnest of later written work. What the children need is the ability to talk clearly and to think connectedly. We do not need so much written work in the elementary school, but we do need more enthusiasm, naïveté, and curiosity and faith. Let the children be awakened to the wonder and beauty of the common world, that they may talk from a deep experience. 


\section{CHAP'TER XIII}

\section{IANDWORK}

"Utility" is the watchword of the twentieth century, and every branch of human effort must meet the test. Science is no longer satisfied with mere speculation, but has become the willing servant of mankind. It diligently searches out the truth, but as persistently hunts a practical application of it. Education has been dragged before the bar and pleads guilty. In consequence it has been forced to throw out of its curricula a whole list of tasks which served no practical purpose, which merely enveloped the student in complacent wisdom and left him staring helplessly at his fellow men. Efficiency, not information, has become the educational ideal. Brain and hand must work together in the solution of life's problems, for to be efficient, as has been well said, is to put thought and feeling into forms which will reach the thought and feeling of others. Little children are by nature efficient, for they are distinctly motor in their reactions. They turn toward construction instinctively, and handwork in the schools has become the surest means of personal expression and power.

Children need plastic material upon which they may stamp their mental images. They need a medium which will receive and objectify their impressions. The constructive, representative instinct which the child so vigorously makes use of is nature's way of helping him to balance mental accounts. By means of it he sifts impressions, and labels them for use. Use establishes intimacy, possession. 
Wear a suit of clothes, and it takes on the individuality of the owner; use an idea, project it, give it form, and it becomes a personal possession.

The child's world is objective ; his images are based upon sense perceptions, and he cares for immediate and visible embodiment of facts. Let him register the ideas he receives in some form of motor discharge. Give him plenty of handwork, for it will make use of the impressions of sight, sound, and touch under the fruitful direction of his creative imagination. Do not be content with school work which makes use of the eye alone, but provide the child with forms of expression which make a larger demand upon his sense centers. Give him an opportunity to coördinate cye and hand by offering him work which demands their coöperation.

Handwork gives the child an opportunity for efficiency in social service. He is full of a desire to help, to contribute something. In his undeveloped state his service must be limited to the things which he can do with his hands. He is not capable of protracted effort, but the simplicity and finality of the constructive work satisfy his desire for direct and immediate results. Handwork wisely directed enables the child to contribute things of beauty and value, and therefore arouses a social pride.

In school work the children need evidences of fruitful effort. They must struggle some time before they can feel their progress in reading and writing, but in handwork they can fairly possess success. They feel the uplift of immediate achievement, of personal power.

Originality of expression is the aim of handwork, but originality is not ready-made. It is the result of experience and an accompanying increase of technique. 'There should be as definite a relation between the demand and supply of technique in handwork as there is between the demand and 
supply of any commodity. The demand for technique should grow out of the use of a variety of suggestive material. Material which suggests or hints a process will make a demand upon originality and call for technique. Handwork may not be judged by the technical results obtained, but by the knowledge the child has gained of the uses and the possibilities of material.

Handwork belongs to the realm of art. It is intimate and personal in character and is a question of individual adjustment. It demands a creative atmosphere and does not thrive under the strict silence of the ordinary school period. Joyous human relations must surround the work done with the hands. The children should be allowed and encouraged to share their work with one another ; to compare, discuss, and lend a hand. It is the child who is permitted to whirl the finished article in the air and invite admiration of it who will feel the glow of creativity. The child who follows the solemn dictation of his teacher and then silently puts his work away has no consciousness of victory. He will never know the joy of the true craftsman. If some freedom is allowed during this period, many boys and girls will receive the first commendation of their playmates through a bit of skillful handwork. This glow of success will be a revelation. This concrete evidence of power will awaken new energy which will flow over into other lines of effort.

What is the moral reaction from work with things? The child's ideas, thoughts, become tangibly visible. Suppose all thought took visible form, would it not startle some of us to look up and see the distorted figure of our habitual thoughts? Handwork must be true and clean to be worth while. A lie in the concrete cannot be hidden; it carries its results with it. The child who works with his hands must think, deliberate, and stand by his conclusions. Exclusively 
intellectual effort is subjective and incomplete, and may become selfish in its motive, but work with the hands is altruistic, objective, and humanizing.

Do not give the children a lot of characterless objects to make. The standard of handwork should be use or beanty, or both. Keep the work close to the lives of the little people. Let them make wagons, jumping jacks, paper dolls, boats, and engines. Such effort will do more to establish honest regard for property than all the sermons you can deliver. Possessions, accompanied by a sense of the labor involved in the making, will open a new page of ethies to the small boy or girl. The child who makes coat hangers, tags, holders for rubbers, pencil boxes, ete. is protecting his neighbor's property as well as his own. He is learning self-respect and independence by supplying his own wants by the work of his hands.

Every primary room should contain a sand table upon which may be set up illustrative work. Each child may have a part in building the farm, the Indian or the Eskimo village, the circus or store. Community work and a common responsibility establish a feeling of comradeship of which the schools are sorely in need. It gives an opportunity for just comparisons and mutual suggestions. The children will work in pairs or in groups of three or four, solving their problems independently but being obliged to conform to the general purpose or plan. If the added joy of secrecy is given by making something to present to another grade, the entlusiasm and effort of the children will pass all expectations.

This community spirit is contagious, and boys and girls from the fourth, fifth, even sixth and seventh grades, have been known to make daily visits to the primary room "to see what the kids are making now." The next step is to ask if they may contribute something. Indeed, the school 
is running over with these opportunities for coöperation, self-help, and personal pleasure in work, but these vital, human aspects of life do not flourish in a silent, austere atmosphere. They are set going by the light of enthusiasm in the teacher's eye and by the wisdom of what seems to be undirected effort.

Handwork is frequently criticized because the material used is so expensive. This is a just criticism, and every teacher should make it a matter of pride to search out cheap material and not be content to check off long lists of costly stuff for the school boards to pay for. For instance, why order tilo-matting for the free-hand sewing when coffee sacking, which grocery stores sell for a song, makes a fine substitute? Old kodak rolls, which the proprietors give away for the asking, may be used for silhouettes in freehand cutting, whereas the black paper used for that purpose is very expensive. Spools, ribbons, old chalk boxes, newspapers, scraps of wood from the manual-training shop which are usually thrown out, and nature material brought by the children offer endless opportunities. A bottle of paste made of flour and water costs a few cents, while the bottles bought by the schools come nearer to the dollar mark. For large brush work with the younger children do not use paints, and then have all the parents asking that art work be omitted, but make an order of cheap dyes which come in all the standard colors and are easily handled. In many cases ordinary pasteboard will take the place of bristol board, and manila paper, which is cheap, may be adapted to a thousand purposes.

The character of the primary work should retain the kindergarten flavor. The primary child is still a kindergarten child, with a little more conscious purpose, with increased power of concentration, added control of material, 
and a more organized imagination. His tastes and joys are almost identical. Give him large, coarse, flexible material; let him choose the material best adapted to his work and have the judgment to discard what is impractical. Let expression rather than technique be the guide in the choice of exercises given. Take time to let the children suggest how to make the object; let them discuss ways and means, not follow directions wholly; give the child one step in the process and let him figure out the next; some of the directions given in handwork with such precision are as unnecessary as lifting a child's feet when he climbs the stairs. When similar or familiar processes are used do not tell them over again, but let the children apply what has been already learned. Seize upon occasional days for free work. This is best accomplished by putting a lot of suggestive material - such as boxes, spools, a variety of shapes and sizes of wood, paste, paper, scissors, yarn, etc. - on the table and allowing the children to choose what they will make, the kind of material they will use, and how they will make the article chosen. Even little children can make window boxes, clay flowerpots, cages for animals, strings and tassels for the curtains, and many other little devices for the comfort and cleanliness of the schoolroom.

Joyous, purposeful activity is the secret of honest living. Little children come to the school with a gift for being busy. The business of the schools is to transform this tendency into purposeful work. Children are not inherently idle or lazy. Idleness and laziness are the scars left by hours of joyless, distasteful work. So long as work is defined as an unwelcome task, so long will idleness increase. School work need not be irksome in order to be profitable, but should be the wholesome expression of changing tastes and increasing power. 


\section{CHAPTER XIV}

\section{LITERATURE}

If our modern doctrines of education were faith, not theory; if we honestly believed in preserving to childhood its imagination, its emotional life, its ideals, and its humor, the so-called reading in the primary school would give place to the absorption of good literature. The word "literature" does not take on a sufficiently clear meaning in the minds of teachers. We do not have it in the schools because we are not sure what constitutes it. A mature person has the privilege of exercising personal judgment in the choice of what he will read; he may discard what falls short of personal approval. A child has no such privilege; he must base his standards and ideals upon the reading matter dealt out to him. When that reading matter is made up of the incongruous stuff contained in the average primer, what is to become of taste and discrimination?

Not one teacher in five hundred is bringing literature to little children. If she interests them she thinks all is well. Interest is no criterion in this connection, for a child will listen to almost anything put in story form. Literature is a question of units of thought, of taste, discrimination, and emotion. Much of the story work done in the grades is as demoralizing as vaudeville music; it is dissipating and cheap. We need to form standards of choice in the selection of literature; we need to have some convictions upon the subject which will guide us in our choice. Many stories told in the early grades are aimless jumbles of words, with 
nothing to recommend them but a kind of sticky morality. They follow no preconceived plan and arrive at no adequate conclusion. Such stories arrest mental development by their fluid imbecility.

How may we recognize a good bit of literature? How may we determine whether a story is worth telling? Every good story is made up of essentials as necessary to its structure as bone and muscle to the human frame. It has a beginning, a middle, and an end. It is a series of related incidents, each one illuminating the other and all converging upon the climax. Before selecting a story, see whether you can write an outline of it in one or two short sentences.

Literature, like life, is made up of action - action so vigorous that it overcomes all obstacles in the way of its success. As in life, the characters in a story should be individual, and full of purpose.

Children's stories should be dramatic ; that is, they should be full of vim, vigor, and sequence. 'The plan of a story should resemble that of a simple drama; you should look for an introduction or opening, in which the boards are cleared and the characters introduced; there should be a setting of time and place, with a natural progression toward a climax. Look over many of the accepted children's stories and see whether there is any "economy of incident," or whether most of them are not made up of a number of unrelated incidents pointing to no adequate conclusion. Unity, action, sequence, and climax should characterize the construction of a story. Imagine a house built without a preconceived plan; what loss of time, what waste space and confusion, would result! A story without a definite method of procedure is even more distressing, for it learls to a lack of organization in the thinking of the children. 
Good literature organizes the imagination, and affords good mental training. The simplicity of children's stories is no obstacle. Take the so-called constructive stories, such as " The Little Red Hen," "The Old Woman and her Pig," ete. Every incident in these stories grows out of the preceding and necessitates the following. One cannot take out one step in the process without destroying the whole fabric of the story. These constructive stories, overlooked by many and considered permissible nonsense by others, hold in their make-up the essentials of good literature. Why? Because there is a simple plot, a main action, a steady movement toward a climax, and a unity of purpose which never falters until the tale is told. The character is introduced, the setting stated, the action set going without quibble or delay. These stories also contain a fair measure of suspense, a point of highest interest, an unraveling of the difficulty, and a definite conclusion. Such stories are moral in their influence, for they lead the mind step by step through a series of organized incidents toward a legitimate conclusion.

"Mother Goose," which, after all, represents the childish heartbeats of the race, is too much neglected. The primary teacher who cannot see the naïveté, humor, and suggestion of "Mother Goose"; who cannot swing to its rhythm, or enjoy the variety of its action, should ask to be transferred to some place in the elementary school where information, not humanity, rules. What does "Mother Goose" offer to the children? Why is it called good literature? First, it has plot, the very beginning of it. A good short story has a simple plot, and usually magnifies one character or incident. Again, the people who jump through the pages of "Mother Goose" have real indivichality, character. Old Mother Hubbard, Little Tommy Grace, live in the 
mind of childhood as tenaciously as some of Shakespeare's characters live in mature minds. It is only a question of development, analysis, complexity. The characters of "Mother Goose" are merely outline sketches, as incomplete and yet as suggestive as children's drawings. "Mother Goose" has movement, climax, and heroic justice. The characters in it quickly meet their natural fate, irrespective of manners and morals. There is no false altruism to suspend judgment, but the lively little characters are born to act, and to meet the consequences of their actions, with a promptness and decision which leave no room for argument.

"Mother Goose" is imaginative, and deals with the unexpected, the unusual, the grotesque, and the deliciously human. It offers a succession of pictures with such simple incident that the children can visualize them as they go. "Mother Goose" is full of rime, alliteration, music. The ear is tickled by the pronounced and constantly changing rhythm. "Mother Goose" is so childlike that it awakens an emotional response, and an emotional response means personal interest.

"Mother Goose" offers a study of motive within the child's comprehension, and starts some analysis of character which is most suggestive. There is always a problem to be solved. Each sketch is a simple problem represented as swiftly and as clearly as a moving picture. The whole story is grasped by the children in its completeness, yet these small units contain the essentials of more complex stories.

Good literature should bring vivid phases of life to the children, out of which each child may take what he needs, what he is ready for. Each child's heart, by inheritance and experience, is attuned to certain responses; it is hospitable to certain suggestions and ready for certain conclusions; it 
will eagerly grasp that for which it is prepared. Literature, therefore, may not be put up in handy pellets. One may not teach honesty on specific days with specific stories, but instead should tell stories just as they come from the heart of the race, with all their ideality and suggestion. The heart of the child will seize upon that which touches it.

Literature is an art as elusive as moon shadows on a still night. It exists for its beauty - beauty of structure, language, and theme, woven together by the threads of human life. It must reflect life, as the clear stream carries on its waters the image of the overhanging tree.

To achieve results in literature the children must have something more than a good story : they must have a good story-teller, - one with quick sympathies and an intuitive knowledge of her group; one who loves the old stories, who feels the pulse of humanity throbbing through them all; whose voice is clear, flexible, interpretive; whose language is simple, direct, pictorial ; who enters into a dramatic situation; who has a keen sense of humor; who is willing to sow the seed and let it develop in its own good time.

A few years ago the Story-Teller's League was organized, and this is doing something to bring to the children good stories, well told. Library training schools have also undertaken to train professional story-tellers. But the primary teacher should jealously guard and exereise her own personal privilege to tell good stories in the familylike intimacy of her schoolroom. "The one supreme need in all this story and child-reading movement," says G. Stanley Hall, "is to eliminate not the vile, for that is readily detected, but the second and third best from the first best. ... The vital problem is to produce and identify the very best, and to save children from the second best, and to get the true and normal child point of view." 
It would take too much space to enumerate lists of good stories. Excellent lists may be obtained from the Pittsburgh Library. It may not be out of place, however, to suggest certain types of stories which should guide teachers in their selection. Besides fairy tales, myths, and legends, the literature period should make room for stories of primitive man and his industries; stories of lumbermen, fishermen, firemen, sailors, and soldiers ; stories of sheplerd life, of children of many different lands, of discovery and inventions. Children should know how the work of the world is done, and be filled with admiration for the men and women who give their lives to its arduous tasks. Good literature should establish a philosophy of life, and awaken a supreme faith in humanity.

It is sympathy, liumanity, and an understanding of life that we need. Any one can accumulate facts in regard to life, but to know it, to love it, to live it, one must feel its beating pulse in literature. Every teacher of primary children should steep herself in the old stories which tell the struggle and victory of the race. Such stories as Dasent tells are simple, frank, earnest, and pure-hearted. 'They deal with elemental emotions, childlike conceptions, and will be forever young. 'They do not take account of the sophistication of later civilization, but carry one by leaps and bounds through the wild country of imagination and heroic adventure. They are direct. In them cause and effect follow each other so naturally that they are within the grasp of the child mind. They are full of mood and poetry, and the children are stirred by them. These classic stories deal naïvely with the fundamental relations of man and woman. Do not be afraid of the fundamental relations of life depicted in these stories. Many an opportunity will arise, if one does not rob the story of its simplicity and 
spontaneity, to bring to the children the purity and significance of those deeper human relations of mother and child, man and woman, brother and sister. Why should such a line as the following be omitted, or subjected to censorship: "And every night the prince lay down beside her"? Literature gives the opportunity to state facts and intimate relations in a vein of naturalness, beauty, and purity which open the door of life and invite the pure of heart to enter. The sophisticated mind must not read into simple relations that which does not exist in the realm of childhood, but allow literature to state the truths of life in all their poetry and romance. The serious, the humorous, the sublime, and the pathetic start out of literature as suddenly and as naturally as bees from the cups of flowers, for life is the sum of all these emotions, and literature is its image thrown upon the heart of the race. 


\section{CHAPTER XV}

\section{READING}

The primary teacher is not allowed to determine whether the six-year-old child is ready to master the technicalities of the printed page. She is instructed to proceed with the course of study without discussion of its merits, and her problem is solely one of method. How can she acquaint the child with the symbols of the printed page with the least unnecessary expenditure of energy? Where is the line of least resistance, and what instincts or capacities has the child which may be directed toward this end?

The kindergarten child enters the first grade with a vigorous command of language and with an unlimited capacity for speech development. His mind is stored with concrete imagery, and he should have accumulated rich experiences of sight, sound, and touch. He has represented his experiences in the crude, bold outlines of drawing, modeling, and paper cutting. Such a background of images and experiences is the prerequisite for reading. He comes to the first grade eager to project these images, for he is still in the picture-making age. Picture making is his means of communication, and if he has no material to use, he will even resort to shadow pictures to express his thought. $\mathrm{He}$ is ready and eager to illustrate his own first reader, and should be allowed to do so.

Little children in this initial stage of reading have no use for a textbook. They should read only from those of their own making. They should begin to cornect object 
and written symbol by being encouraged to tag or name the pictures they have drawn. Such work gives a feeling of possession and intimacy with words.which the orthodox primer never can awaken. Give the children large sheets of manila paper and a crayon, and let them begin there and then to combine picture and symbol in a book of their own making. As capacity for remembering and representing symbols grows, small pictures cut from magazines may be used instead of the drawings, and the writing gradually reduced to a corresponding size. The child with a bit of encouragement soon passes the tagging stage, and will express his thought in short, simple sentences. These sentences will provide for abundant repetition of the same symbols without intervention of the teacher with her prescribed lists of arbitrary words. The child naturally repeats himself, and his interests are so uniform that a teacher with half an eye can see to it that the child acquires a definite and ample vocabulary. 'The results of this kind of composition will bear inspection in regard to the choice and use of words better than the stupid reiterations of the average primer.

In spite of theory to the contrary, we are still putting the cart before the horse, as of old. We boast of new methods, and flatter ourselves, because we have laid aside the A B C's of our forefathers, that we have arrived at unique and practical instruction in the art of reading. Visit the schools and see whether this is true. See whether the children are not studying tiresome lists of isolated words and reading the vapid, unrelated sentences which are spilled over a prescribed number of pages. There is no doubt but that the children's minds are being stored with visual images of empty symbols in the hope that some time in the future they will tie a thought to them. 
Children have a record-making tendency and arrive very early at a period when they begin to substitute signs for ideas. This natural desire to record facts and events may be used advantageously in the teaching of reading. Records should be made of personal experiences, of observation, discovery, and of results of constructive work. For the very young child these records should be purely pictorial. But as he enjoys a greater variety of experiences and grows in the power to represent them, picture and symbol should be combined. Finally, he will lay aside picture making and be ready to cope with the technicalities of the printed or written page.

The average reader eliminates the personal element, and substitutes a series of sophisticated sentences which will force the repetition of particular words, irrespective of the child's need of them. The compilers of these books proceed upon the presumption that a child must be presented with a ready-made vocabulary, so that if he should chance to think for himself at some future time, he will have the means of expressing his thought. Vocabulary does not grow in this way. Words come dancing into the child's mind fast enough when they are invited to clothe ideas. Necessity is truly the mother of invention, and children have been known to coin their own words to express new ideas. The imitative lip reading of the early grades will never make intelligent readers nor build up language power. The forced and dramatic repetition of these inoffensively commonplace reader sentences is affectation, not interpretation. When feeling is genuine, the voice will make it known. Does any one have to force a child to exclaim over a Christmas tree or a kite? So-called expression in the early grades is all overdone. Most of the material is too stupidly commonplace to call for oral expression at all. The whole purpose 
of reading, which should be to think by means of the printed symbol, is buried under the ruinous temptation of the schools to make precocious readers. These little superficial word-tellers tickle the false pride of parents and win approval from doubtful superintendents, but they lose the power to think, or to get thought from the printed page.

There is entirely too much oral reading in the early grades. We should substitute abundant silent reading, silent, earnest grappling with the printed page to get some needed information. There should be discussion, questioning, exchange of ideas between teacher and pupil, but a very limited amount of oral reading. The child, in reading the simple sentences which are within his eapacity, has no occasion for oral reading. The prevailing habit of voicing empty phrases, and of substituting for interpretive thinking insistent emphasis upon tone, position, and correctness, is disastrous to self-culture.

The silent reading referred to does not mean that a child may not vocalize what he reads. In fact, this is just what he should do when grappling with new material. Silent reading means reading to one's self to find out something, in distinction from the perfunctory reading aloud to the teacher and the class. Such declamation is precocious, elocutionary, inartistic; it absolutely vitiates wholesome expression. It is true that the ear must reënforce the eye in the early process of reading, but it is only the child himself who needs to hear what he reads. His rocalization necds to be barely audible, and should not disturb any one. The child has acquired his spoken language entirely through the ear, therefore the sound of a word calls up its meaning far more readily than the sight of a word. This necessity for vocalization represents a transition period, and the child should be permitted to vocalize as long as it is an aid to 
interpretation. Children vary in this respect, and individual differences should be respected. In some children this connection between the nerve center's of hearing and articulation is as deep-seated as right-handedness or any other innate tendency.

The symbols with which the child comes in contact should provide information, reënforce experience, clarify his thinking. Their mastery should enable him to get thought independently from the printed page. If such an ideal is borne in mind, how many terlious hours of oral reading will be taken out of the school. Through silent reading the children are taught to seize upon the high places, to get at the substance of the thing read, and to put their energy into thought-getting instead of into artificial delight in the sound of their own voices.

The difficulties of mastering the printed page are as great as any ever offered by the elementary school, and yet we complacently present them to the child of six, and are impatient of progress. The mature man or woman, to whom the technicalities of reading are perfectly simple, is allowed to fix his eyes upon his book and to read without interruption. The child, on the contrary, who does not know how to keep his place, whose eyes are not coördinated for the finer movements required by reading, is made to look up after every line, and to give out a vapid sentence, such as "Willie has a hat," with the inflection and satisfaction of a scientific discovery. A small boy whose initiation into reading had been unaccountably difficult came home one day radiant with delight. He had been finally allowed to go into the second grade on trial. He said: "O mother, now I can read all right. My teacher lets me read just the way papa does, and does not make me lift my eyes up and smile after every story." Such 
interrupted, piecemeal reading is a destroyer of thought, and focuses the mind absolutely upon the mechanics of the printed page.

It is only fair that the reading of the primary school should be subjected to inspection and realize some literary standard. A child should read for two reasons : to add to the sum of his knowledge, and for pure delight; that is, for the dramatic or humorous or storylike quality of what he reads. Submit the reading lessons of the primary school to such a test, and how many of them belong in the wastebasket? Rearling should not be an end in itself, nor should it be accidental, but it should be an illuminating accompaniment to the literature, handwork, history, and geography of the grade. With younger children this ideal can only be upheld by making free use of the blackboard. The children should make their own reading lessons, with the teacher. These lessons should be written in large, bold script on the blackboard, so that they may be summaries of the day's work, put together, changed, or erased, as the needs of the children demand. Only when the early work is made up of sentences taken from the personal daily interests of the children will it be vital. Only the events and facts in which they have taken part are worth recording if the children are to be required to read the records. Reading lessons which are made with the class are constructive in character; they take on the quality of the handwork which so fascinates and educates. What the reading lessons need is a feeling of creativity on the part of the child. 'This is accomplished when a child is encouraged to picture his own experiences in simple sentences, and to become a factor in the construction of the story which he is to read. Is there in the average reading lesson anything like the sensation which the child gets in handwork 
when he makes a wagon, and then pulls it along the floor? The triumph of construction, the personal glow, the added power, and a desire for more work of a similar character are conspicuously absent in reading lessons. Such will continue to be the case until the teacher lays aside long lists of words to be memorized, and seizes upon lists of kinclred topics out of which a childlike vocabulary will - pour as water from a bottle. Words are mere instruments of thoughts. Awaken the thought, and the child will command the instruments.

A word properly presented to a child is a picture. He adds it to his thought-stuff as he puts a dress on his doll or a spoon in his cup. Visit an art gallery. Which pictures will you remember after a few days? Only those which have brought to your mind some personal experience, which reflected your own emotional life, which you understood because of some vital association. Words should be presented as pictures of thought which have a personal meaning, and not as elements or combinations of sounds.

Let the reading lessons of the primary grade take on a story quality, that they may profit from the energizing effect of interest and enthusiasm. Repetition is necessary to enforce a needed bit of information, but repetition with variety may be had if true literature is studied, and the qualities which have made it the mouthpiece of the race are inserted into the reading lesson. Compare the language of "Mother Goose" with that of the average primer. Study the kind of repetition which "Mother Goose" contains. It grows out of and is a part of the story, while in the primer repetition is an arbitrary thing, set in for the obtrusive purpose of enforcing some word. Let the qualities which enter into game life - expectancy, repetition, imitation, action, and joy — find their place in the reading lesson of the primary 
school. These human, efflorescent, dramatic qualities characteristic of child life may be erystallized into reading material by a quick, effective use of the blackboard, and in the reading books of the child's own making.

There is not enough reading to children in the primary years. A child should be read to every day without being expected to make any return. Spoken language is acquirerl by such means. One is willing to talk and talk to a child, long before he is able to answer with a spoken word; the child understands, although he says nothing himself; he is collecting the material of speech, storing it somewhere, and sometime he will suddenly surprise you with his accumulated possessions. Reading has this nascent period too, and a child should have the opportunity to follow with his own book in hand a good reading of familiar stories again and again, that the printed symbol, and its oral expression, may be unconsciously identified. By such a method a child gets technique, and the thought expressed by it, without too much conscious focusing upon the technique itself. He will become accustomed to read as rhythmically as he talks, without stilted and forced inflection. Six or eight minutes given to this practice each day will increase the desire to read, give conscious models for imitation, and train the class in attention.

Reading should lead to imagery, association, feeling, and motor response. Does the average reading book excite such responses, or does it deal with conmonplaces which are merely rolled about on the tongue?

The reading lessons are apt to go ahead of the child's power, - we are so impatient of progress, so jealous of time. We lay too much stress upon the number of pages covered, too little upon the desire awakened and the taste acquired. 


\section{PEDAGOGY OF THE PRIMARY SCHOOL}

Children should be allowed time at least once a week for undirected reading, - save as to a suggestion of what to read, - time to read with no thought of reproduction other than a voluntary one; they should have time to read for mere delight, to form a reading habit, and to establish reading tastes.

Reading is thinking by means of the printed page, not the technical mastery of words. Little children are in the language-building period, and if the proper transition is made, will quickly learn the language of the printed page as well as of the spoken word. Their interests are so varied and their curiosity so keen that one cannot set the limits to what they may acquire. The secret of success is to keep the work childlike, full of action, and vitally related to the daily interests and habits. Children are accumulating, putting together, labeling, classifying, and selecting in a wholesale sort of way. They are open to suggestion along a thousand different lines, but ready for prescription in none. 


\section{CHAPTER XVI}

\section{HANDWRITING}

I. Writing in the race. Handwriting is one of the latest and highest achievements of man. Geiger calls it "the most marvelous art which it was at all possible for man to create." Like all great things, it is the result of a long, gradual development.

The beginnings of the art were rude and desultory scrawls such as even eolithic man must have produced in his idle moments, prompted by the old instinct of workmanship. The rudinents of handwriting in the child are found in playful scribbling similar in origin and character. The hand is a most natural means of expression as well as of construction. The facial and laryngeal muscles scarcely exceed it in mobility and sensitiveness to mental states. Just as the dog's tail, not being burdened with the task of locomotion, became an animated semaphore, with a considerable code of language wags, so the hand of primitive man became the vehicle of communication. The hand is anatomically so superior to the canine tail that it lends itself to a high development of sign language. The gestures of primitive man at first surpassed speech in efficiency. Living primitive people show marvelous power in hand talk. To this day the Indians of the Mississippi Valley, with their scores of dialects, cannot understand each other by word of mouth, but they meet on the ground of a universal gesture language. By this Esperanto of the hand they can trade, negotiate, and even tell each other love stories. 
There are innumerable nerve filaments which bind the fingers to the brain cortex. With the development of mental imagery and mental coördination, pictures emerge out of the rude, aimless scravls, somewhat as articulate speech arises out of babbling and cooing. Picture writing is really a form of gesture, - graphic pantomime. "On bark and wood and stone, on skulls and skins and bones and teeth, on. surfaces formed of various fibers, and with some tribes on the human body in tattooing, the pictures were made according to the exigency of the case or the whim of the artist."

The pictographs were, of course, very rude, concrete, and unconventional. It took hours to tell a simple story which we now could write out in as many minutes, but in these same rude pictographs, as Huey says, "lay the germs of the alphabets which made civilization possible." In some cases the historian has actually traced ont the pedigree. Our letter M, for example, passed through seven distinguishable metamorphoses, starting with an Egyptian hieroglyphic owl. It surely is interesting to reflect upon the immense gap between the laborious, slow-witted etchings of the cave man and the modem lightning stenographs which are dashed off at the rate of two hundred words per minute; but it would be wrong to think that there is no genetic relationship between pictography and penmanship.

II. Motion-picture writing. The pedagogy of penmanship must recognize the genetic background of handwriting. Primitive man wrote pictorially before he wrote alphabetically, and so should the child. Even Pestalozzi appreciated that there is some pedagogical connection between elementary drawing and writing. To the primary-school child handwriting is about as foreign and impossible as it is to a patient suffering from the brain troubles known as agraphia and alexia. The highly complex and conventional symbols of 
the copy book are as foreign to his experience as Sanskrit is to most of us. If we want to draw out his powers of hand-expression, we must make connection with his own stock of concrete, mental images.

And the beauty of it is he has just those visual-motor images of motion which are pictorial in import but contain the basal elements of handwriting. These mental motion pictures which he so easily and joyfully transfers to the blackboard make a splendid transition from drawing to penmanship. The crude sketches of men, animals, houses, ete. of course come first of all. Through these drawings the child develops his powers of coördination and perception, but he will represent moving things as naturally as stable ones, just as primitive man in pantomime, dance, and pictograph represented the rocking of the waves, the heaving of nets, or the flight of birds. Such dynamic, pictorial representations will resemble writing as much as drawing, because they will have the progression and continuity of fluent script.

If children are too suddenly and arbitrarily introduced to letter forms, expression is stilted and crippled. If we start with the copy book, the child has neither motor images that command nor coördinated muscles which execute. The use of pictorial or representative writing in the early stages is effective because its starting point is familiar motor images related in the child's mind to pleasant reactions. In language making the child imitates tone, inflection, and rhythm of speech before he masters words ; so in writing there is a play period working toward muscular control which expresses itself in bold, flowing, pictorial representation of rhythmical sound and movement. Children will only write easily when the mind is filled with easy, continuous motor images which are so compelling that they coax the muscles into involuntary play. 
Their first writing should represent ideas, just as the primitive pictographs did. Children are, like primitive man, in a naïve, creative, responsive, artistic, representative mood, and if encouraged will represent motion in lively, flowing lines upon the blackboard. Their minds are full of innumerable motor images which they have met with peculiar delight in their kinship with nature. They love to watch the trees bend in the wind, for the delight in the regular recurrence of action and sound is instinctive. They feel the poetry of motion, and easily and spontaneously portray it; for instance, in such an exercise as the following:

How do you like to go up in a swing,

Up in the air so blue?

Oh, I do think it the pleasantest thing Ever a child can do!

Up in the air and over the wall,

Till I can see so wide,

Rivers and trees and cattle and all,

Over the countryside;

Till I look down on the garden green,

Down on the roof so brown -

Up in the air I go flying again,

Up in the air and down.

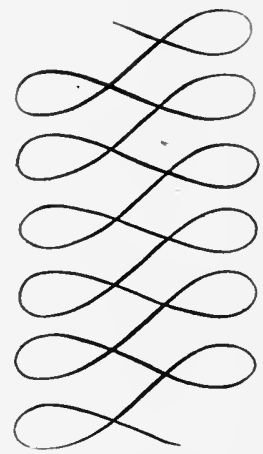

Fig. 36. GoING UP in a Swing

In this motion-picture writing the children are living over again the psychomotor joy of swinging. They let themselves go as it were, while they draw these lines, and

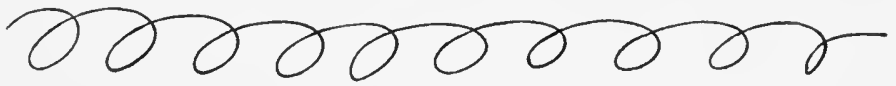

Fig. 37. Rolling Hoor

may even say, as one little fellow did, "I touched the top of the branch with my toe!"

Rolling a hoop is another childish sport which may be used for this pictorial work. Children do not care to 
make ovals, but how they love to roll a hoop lightly, evenly, smoothly down the board. If they press too heavily

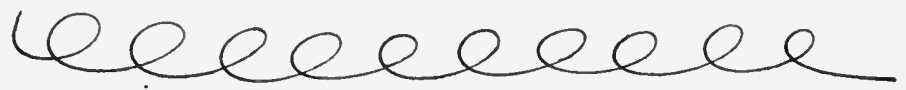

Fig. 38. JUMPING Rope

upon the chalk, the hoop will upset; if the motion is not continuous, flowing, even, the hoop will cease to roll.

The same exercise, or the reverse, may represent jumping rope, and the accent or rhythm may be made to fall upon the lower line, as if the rope quickly struck the ground in successive swoops.

Among many other rhythms and motions which may be pictorially represented are the swinging of the pendulum, the beating of the drum, and the marching of soldiers down the street. The skyrocket may be represented with a vigorous oblique stroke made to the sound of $s h-s h-s h$ ! 'The cadenced humming of bees is naturally represented by rhythmic continuous lines.

The type of pictorial writing here rec-

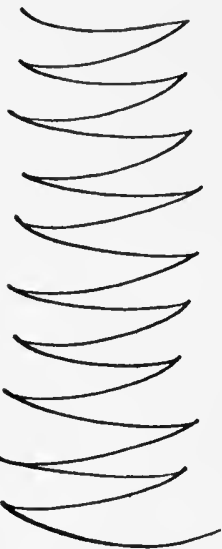

Fig. 39. Swinging

Pendulum ommended is not to be confused with the construction of spectacles, vases, etc. out of combinations of ovals and curves. 'Though such exercises may have some value, they

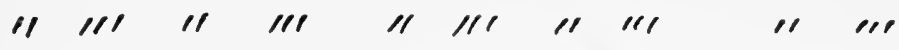

Fig. 40. Beatixg Drum

portray still life, and do not develop that feeling of rhythmic movement which is the soul of true motion pictures. They are not dynamic. 
Judd has made a psychological analysis of the writing process which seems to bear out some of the points in the suggestions so far made. "Writing," he says, "has to be

Fig. 41. Marching Soldiers

developed by trial after trial; that is, by tentative effort until the proper movements have been hit upon a sufficient number of times to establish them without conscious selection, with consciousness directed not upon the move-

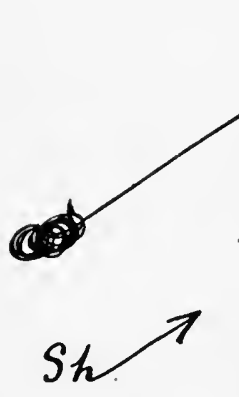

Fig. 42.

SKYROCKET

ment itself but upon the visual images which appear as results of the movements. There is no conscious selection of the hand movement. Various factors are gradually added to each other by a process of organic fusion." For a half year, and perhaps ideally for a whole year, the child should be kept at this bold, motion-picture writing, the impatient anxiety of $A-B$ - $C^{2}$-minded parents notwithstanding. 'This dynamic drawing can be filled with much joy, even beauty, and we may be sure that in its performance the child is laying the foundation of the pyramid of habits called handwriting.

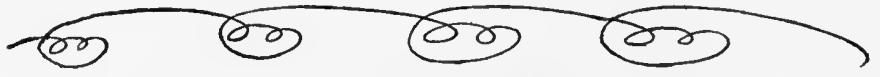

Fig. 43. Bees humming

III. The rhythmic writing mood. In Volume II, the fifteenth lecture of his work on "Experimental Pedagogy," Dr. Ernst Meumann makes an interesting analysis of the writing process. By means of a delicate pneumatic apparatus and a revolving smoked drum, he secured records of the 
variation in rapidity and pressure of the handwriting of ehildren and adults. He found that six-and seven-year-old children never exert a rhythmical pressure within a word; that is, a maximum showing itself in a wave crest at the beginning, middle, or end of "the pressure eurve," as indieated in the aceompanying diagrams. 'The beginner' always exerts equal uniform pressure for

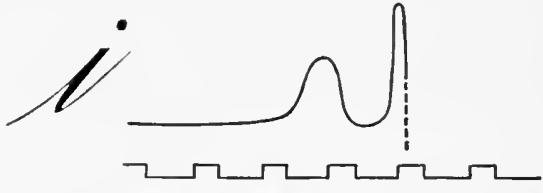

Fig. 44. Pressure and Speno Curve for LETTER $i$ (AnULT) every letter, or at first for every stroke. Meumann found that adults likewise show a temporal rhythm, - that is, rhythmic slowing and aceeleration, - while ehildren tend to write their words with uniform speed. Children also exert a greater absolute pressure. Figs. 44 and 45 are the pressure and speed eurves of an adult and a child writing the letter $i$. 'The lower lines in each figure are the time reeord, the notehes in that of Fig. 44 being the marks of a metronome beating sixty times per second. Note in the boy's writing the slowness, the uniform pressure, and the three separate impulses, one for eaeh stroke.

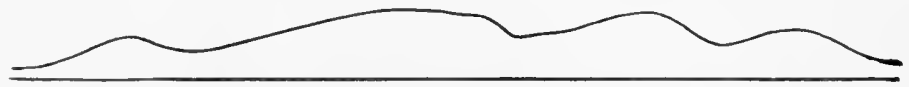

Fig. 45. Pressure and Speed Curve for Letter $i$ (SevenYear-Ole Boy)

On these data Meumann eoncludes that the development of handwriting in children consists chiefly in that, first, it becomes more rapid; seeond, that the separate impulses fuse into one total impulse with a rhythmieal subordination of individual pressures to one chief pressure, till the innervations of a word result in a unitary act in which the whole 
word is executed with one stroke of the will. He also thinks that the individual letters should be mastered thoroughly before proceeding to the writing of words.

This analysis, instructive as it is, betrays one of the chief limitations of experimental pedagogy. The technical methods of laboratory analysis must often fail in evaluating the factor of mood and attitude in the learning activity of children. Our experience in the classroom has proved, first, that the six- or seven-year-old child does not need to exert undue pressure in his writing; second, that he need not write unrhythmically either in pressure or time; third, that he does not have to write in a piecemeal manner with numerous separate impulses; fourth, that words should not wait for the mastery of individual letters. From the very start the beginner's penmanship may possess the adult qualities of fluency, accent, and individuality, if it will only spring from familar imagery and the rhythmic mood. Meumann's analysis indicates not so much the natural and necessary development of children's writing as the baneful results of poor methods of teaching.

Surely it is not natural for a child to draw in a patchy, piecemeal fashion. Watch him at his drawing and see with what fine daring and abandon he makes his lines. Put a pencil in his hands and ask him to write, and he glides it across the paper with a continuous and often graceful motion. A circle of kindergarten children were asked to write a letter, and only two of them made circumscribed scrawls; the remaining eleven went bravely and flowingly across the page after the manner of the accompanying cut (Fig. 46).

This natural, continuous movement should be cultivated, not combated. The very purity of motion which is the ultimate end of writing, and which the child brings to school, is broken up by jerky, painful movements in 
premature striving at technical control. This results in the absurd draftsmanship in which even such a decided unit as 0 is built up by installments. An examination of the

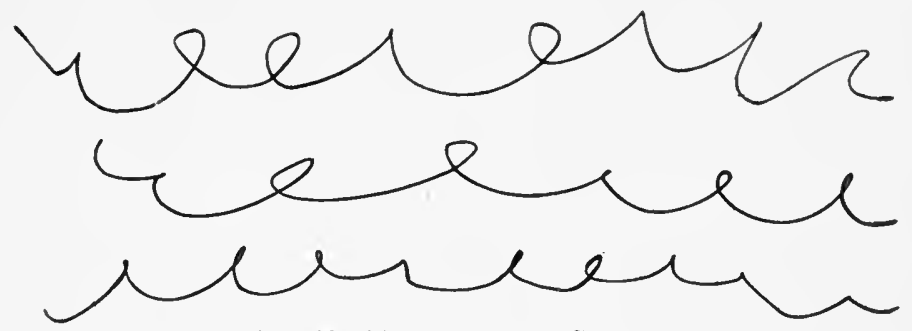

Fig. 46. Kindergarten Scrawl

specimen in Fig. 47 will show how almost every letter is the result of two or more independent strokes. Writing is motion directed by thought, and should be a fluid accompaniment of thought. The specimen in Fig. 48 , taken from
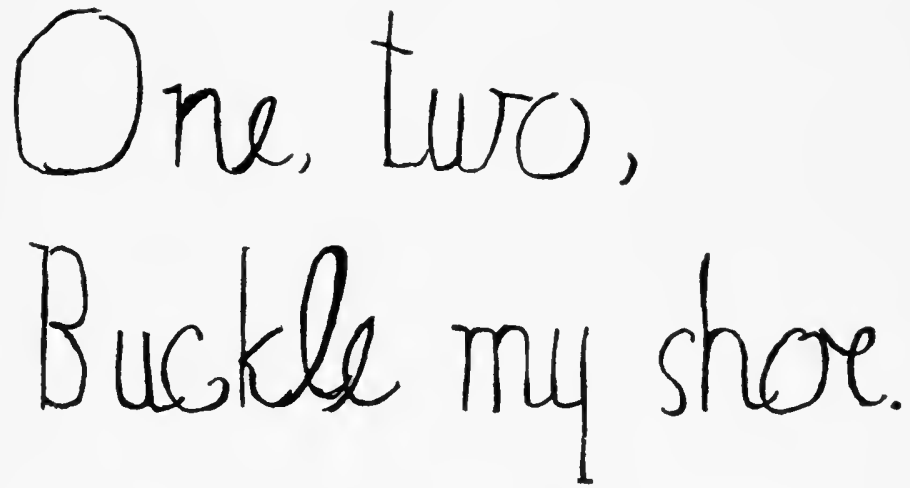

Fig. 47. Legible but Pieceneal Writing

a boy's essay on mud, is not to be commended for legi- bility, but it at least has the merit of fluency, so conspicuously absent in the other specimen. A good method of teaching will secure both merits. 
Meumann has said: "While the adult writes the whole word with one will impulse, the child has to make a number of separate efforts, - as many as there are letters or separate strokes. The child writes with individnal impulses, the adult with merged impulses (Gesamtimpulsen)." May this not be due to the fact that the early writing of children is usually a dull, tiresome, commonplace effort to reproduce arbitrary forms? Monotony will destroy the cleverest bit of oral language, and so it will inhibit writing; for writing is the transmission of thought, and must take on its rhythm. Separate, unrelated words awaken no impulses which call for unitary motion or decisive strokes.

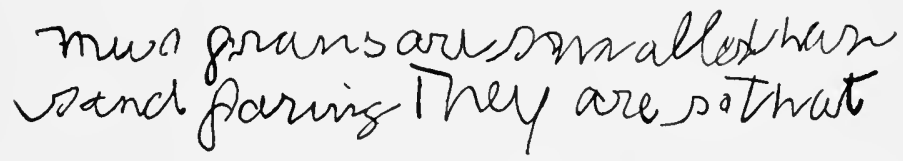

Fig. 48. Illegible but Fluent Writing

The adult writing movements follow thoughts and ideas, and naturally express accent and rhythm. Emotion produces a corresponding movement, and the fault in the writing of little children is that all emotion is lacking. The writing is simply muscular gymnastics, without impelling mood or idea to give it fluidity or grace. Motion-picture writing, enlivened with rime or song, supplies the deficiency, and trains the muscles to execute the needed form of writing in company with feeling, the rhythmic mood.

This attitude of rhythm is so invaluable in writing that it is worth special cultivation. The rimes of "Mother Goose," from the trotting movement of "Hey diddle diddle" to the slow measure of "Fe, fi, fo, fum," furnish excellent material for concerted rhythmical expression at the blackboard. These rimes represent a variety of recurring accents which bring into play a corresponding variety of 
muscular contractions in a natural, controlled way,_- " Hey diddle "expressed by short staccato strokes like „ ״,; "Fe, fi, fo, fum," by longer strokes like _ _ _ _ . A combination of these strokes may be used in " Three Blind Mice" ; as, Three blind mice, They all ran after the fármer's wife, Who cút off their táils with a cárving knife. Three blind mice. The long strokes may also be made vertically, and the short horizontally, and there are endless other variations. Unaccompanied by mood and motive, these fundamental strokes, which are at the basis of writing skill, are impossible in children. On perfunctory prescription the simplest lines will be hesitant and tremulous.

In presenting these exercises the teacher should merely establish the desired rhythm, set it going, and then, lowering her voice, gradually withdraw her guidance altogether. The pulse or rhythmical measure started seems to incorporate itself into the sensitive neuromuscular make-up of the little children, and they continue to hum or sing softly, and write in flowing, cadenced lines until a new measure is suggested.

Rhythm is the best friend of motor activity. It lightens all labor, makes for pleasure, grace, and poise of movement, and postpones fatigue. The workingmen of to-day, like their primitive ancestors, make rhythm an ally in physical toil. Melodic intervals possess in a high degree the power to stimulate energy. Experiments in the laboratory have shown this to be true in the case of the ergograph. This is an instrument in which the subject successively depresses a weight with one of his fingers to test his physical endurance. Rhythmical grouping of the finger movements improves the record. Meumann found in his own tests that under the impulse of the rhythmical beating of the 
metronome the handwriting of ehildren, though it may suffer somewhat in accuracy, becomes faster, more facile and fluent. The Romance peoples-Latins, Spaniards, Mexicans, and Italians - are proverbially good writers. May this not be that, because of racial temperament, they fall more easily into the rhythmical mood which gives beauty and grace to all movement?

Dr. E. W. Scripture, who has made a scientific study of speech defects, finds that the laryngeal cramp may be broken up by the melody cure. In his speech clinic, where only a few minutes ean be given to each stutterer, he relies chiefly on this melody cure. The element of rhythm in this cure undoubtedly has something to do with breaking the cramped stiffness and restoring flexibility. Dr. Scripture reports an instructive case of stuttering in penmanship: "A Mr. H. has taken courses in writing, but had suffered so much on account of his penmanship that a nervous fear seized him the moment he took up a pen. Before beginning to write he would make a number of nervous strokes with the pen without touching the paper. His writing grows steadily more cramped and tremulous as he approaches the end of a word" (see Fig. 49). Though this is an extreme and rare case, milder degrees of this embarrassed penmanship are plentifully produced by those methods of teaching which are stilted and atactic in their very spirit, instead of partaking of the child's joyous love of motion.

While the children are at the blackboard enjoying their rhythmic motion pictures they are standing erect, with the chest up and their lungs full of air ; the circulation is unimpeded; muscular control and a harmonious use of the whole body follow of themselves. The symmetrical posture and well-balanced neuromuscular tonicity favor the use of 
the left hand as well as of the right. In the midst of the exercises the children can be made to exchange their chalk from one hand to the other for a moment or two, not with a view of cultivating ambidexterity, but to get the advantages of cross-education and to increase the rhythmical mood so essential to perfect writing.

Such free blackboard exercises, because they are fluid, childlike, and rhythmical, eliminate all muscular tension. It becomes a game to hold the chalk so lightly that if the

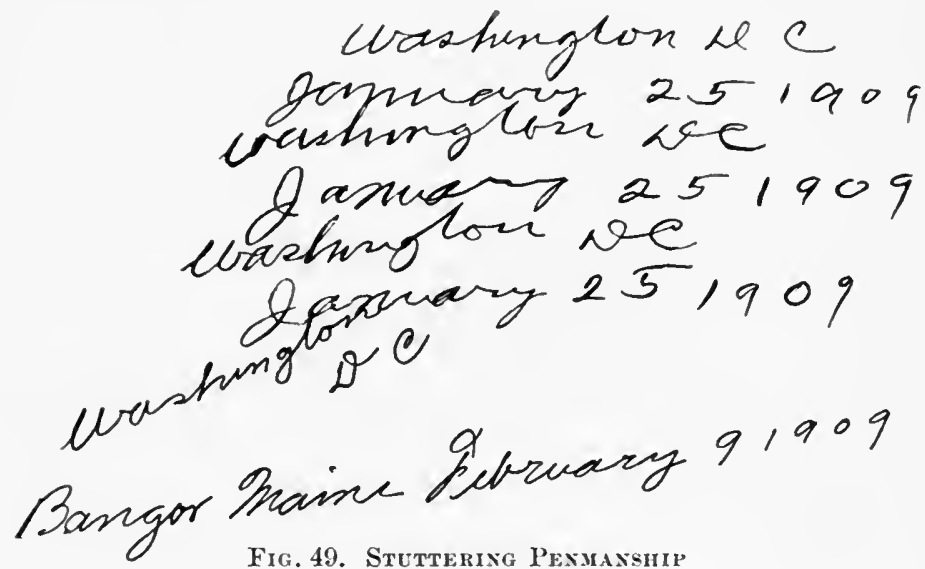

teacher slips up behind a child she can pull it from his hand - without effort. To encourage lightness of touch an exercise like the following is most useful: "Make soap bubbles, make them lightly; there, yours will break. Barely let them touch, - softly!" The children will make a number of them quickly, lightly, without any cramping of the muscles if the teacher makes them feel the ethereal fragility of the bubble. Thus even the excess of intensity, which is supposed to be the natural accompaniment of the leaming process, can be much reduced if only the proper attitude is developed. 
For children work by mood, and this principle is the success of all teaching, especially of the teaching of primary-school writing. Emotions tend to produce movement; conversely, if handwriting lacks emotion, movement will become cramped, perfunctory, and lifeless. The rhythmic mood is the very joy of motion, and holds all the cardinal traits of handwriting, - facility, fluency, grace, and speed.

IV. Word-picture writing. Motion-picture writing has so much dramatic play-joy for children, and so much true gymnastic value in developing posture and body control, that it might well be used for its intrinsic educational and recreational worth. We are, however, recommending it as a preparation to the acquisition of handwriting, and an accompaniment of it. But how, it will be asked, if children are to be kept so long at this flowing blackboard work, will they ever learn to write letters and words? The transition is made very easily, almost unconsciously. To begin with, the motion-pictures themselves contain the fundamental strokes of handwriting, and their systematic, lively repetition will so automatize these strokes that the technicalities of the alphabet will be much reduced in difficulty. Moreover, the making of lines and curves to the saying and singing of "Mother Goose" is, after all, a very real kind of writing. The essential thing in the rimes is their rhythm, and this the child really expresses in his broadly symbolic lines. Besides, the child does it all in a spirit of playful self-illusion, and thinks that he actually is writing the rime; and after he writes it he reads it back to himself. Early picture writing represented ideas in a few bold strokes, and so does this disingenuous rime-and-motionpicture writing.

Then some of the pictures are really letters. The hoops are $o$ 's, the swinging rope contains $e$ 's and $u$ 's, and the 
humming of the bees incorporates $n$. In time the exercises can be varied to incorporate other letters, or even combinations of them; but these letters are always to be made in a flowing, easy fashion, in the natural relation of forward, fluent movement, unhampered by the crippling consciousness of form. 'The painstaking, arbitrary drawing of $a, b, c, d$ is unchildlike, self-conscious, and irksome, — defeating its own purpose by creating a distaste for writing, setting a habit of slow, characterless script, and dissociating writing from all ideas. Writing in the minds of most children is an unwelcome task, and has no relation to record making and communication, which is its excuse for being.

It is no longer considered pedagogical to dissociate primary reading from feeling and a desire to communicate and understand. We wish to call attention to the identity of principles underlying the acquisition of reading and writing. Both functions may be lifeless, stilted, and monotonous, or may be the opposite. Both may be painfully self-conscious, discrete, analytic, and hypertechnical, and both benefit by the whole method as opposed to the part method of teaching.

It has been proved experimentally that children can perceive - that is, recognize and name - words about as readily as single letters, and the same is true in a measure of sentences. The word is a natural, vital unit. Its visual appearance, indeed, is not a sum of letter appearances, but has a character of its own. Children are very susceptible to the individuality of words, and though it may be logical to split the word into its alphabetical elements, it is not psychological. The old writing masters used to begin their writing lessons with monotonous drill on artificial units like hooks and loops, thinking that the logical procedure in penmanship. This method is really as absurdly unpedagogical as the $A-B-C$ method of teaching reading. 
Prolonged practice on isolated $a, b, c, d$, before attacking words, has no more place in writing than in reading. Children should be encouraged to do what is so natural and possible for them, - namely, to take in the whole word, and to write the whole word, as they draw a whole picture. They will grow tremendously in this power to picture whole words, - which, by the way, will greatly improve their spelling, for spelling is nothing more nor less than the ability to write correctly.

Orthography means literally "straight writing." This correct writing of words should be natural, and should be brought about by positive, not negative, impressions. There is no place in the early school work for arbitrary lists of isolated words to be spelled. A definite content or sentence relationship should be associated with the visual image of every word studied. Children should be encouraged to look again and again at the correctly written word, until the image of it becomes indelibly fixed. 'The trial-and-error' method frequently resorted to brings about inhibition and mistaken images, which often persist for a lifetime. Do not allow a child to write a word incorrectly, for the corrected papers which are returned to him only fill his mind with distorted images and false impressions.

Have the children look attentively as the iword is written on the board, perhaps erased two or three times. Then let the class write the word quickly and with decision. Such exercises will reduce the number of individual impulses, and make unnecessary the mastery of separate letters before proceeding to words. After a while the children will not only picture words but also sentences, and write the sentences as easily as the word.

We have eliminated the letter consciousness in reading, and should apply a like pedagogy to writing. Writing is 
picture making, and the letters of a word maintain a definite relation one to another, just as the lines of a drawing. It is the relations, combinations, and fusing of the letters which give individuality to words. It is not the letter consciousness, but the word conscionsness, that should be aimed at.
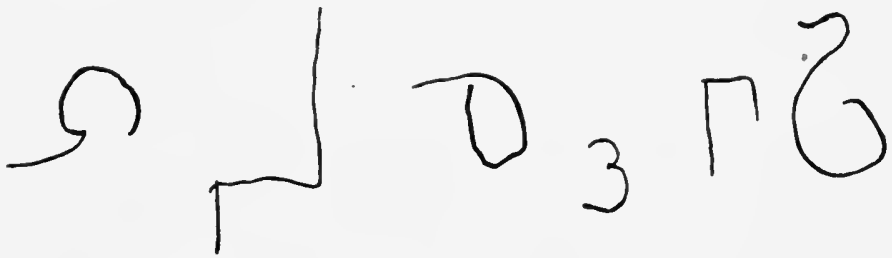

Fig. 50. Iindergartex Copies of 2, 7, axp 6

A perfect word picture, it must be admitted, does not always secure corresponding results in writing. The model and the visual image must be properly associated with motor impulses before the copy will be accurate. A group of kindergarten children were asked to copy a large 6 and 7 displayed before them. The figure above shows some of the more interesting errors resulting from the test. These

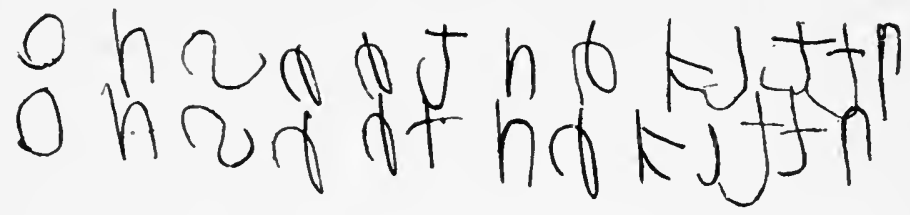

Fig. 51. Ixversiox Script ("On, see the Kitty")

errors are due not to perception, nor to a lack of muscular ability, but to an absence of coördination, point for point, between the visual and motor factors. This lack of visualmotor coördination accounts for the strange inversions which so often appear in the writing of primary-school children, such as are shown in the writing in Fig. 51. The piecemeal analysis of words and letters may also contribute 
to the dislocation of parts. In one primary-school room which was visited it seemed that the majority of the children lapsed into writing inversion.

How may these inversions be avoided? By making the whole word a motion picture. Let the children see not only the static, dead model but the dynamic unfoldment of the model, - the word. Let them see and imitate the movement as well as the result of the movement. In brief, let them see the teacher writing the word, so that they will have a word-motion-picture.

There is another feature of good writing, which depends upon proper imagery rather than upon prescription and scolding; that is, writing in a straight line. Even begimners do not need lines for their guidance. Show them how to place a dot where they begin to write, another where they should end the sentence, another in the middle for those who are most inclined to write uphill. The children will then soon begin to think straight lines and have mental line pictures, and will correct their own mistakes. Go about with a ruler occasionally and place it under the sentences written, so that the child may see his error. Lay the ruler also on the top where the tall letters should reach, and so awaken a healthy self-criticism.

Another minor problem is the transition from blackboard to paper. When the time comes to make use of the pencil, the children should be given large sheets of wrapping paper and be encouraged to use the same large, flowing script. It has been found practicable to have the children fold the paper, gradually making it smaller and smaller, until the script is reduced to a comfortable, normal size.

Speed and accuracy are painfully difficult problems if writing is acquired after a logical, alphabetical, calligraphic 
manner, but not if a premium is always put upon spirit and rhythm, and words are written as fluent wholes. Free activity, rhythm, and emotion, rather than analysis, characterize childhood. Oral language, the inspiration of written language, is acquired, not by intellectual analysis, but by imitation, suggestion, and play. A method realizing these ideals should extend to written language. If the spoken language and oral reading of children are made self-conscious by phonetic analysis of words, evil consequences will follow. Misguided phonetic drill has been called the breeding ground of the stuttering habit in our elementary schools. If this is true of the speech habit, why should it not hold true of the writing luabit? There is, indeed, a vast amount of awkward, hesitant, more or less atactic writing in our schools, for which the hyperlogical, alphabetic method of instruction must be held responsible.

A recent system of writing, for example, recommends in its teacher's manual the analytic presentation of words, and even of letters, as follows: "Came. Begin the word 'cow' with a dot, come down, turn, go up, come back, turn, go up, close the o, or oval, go over, make a point, come down, make turn, go up, make angle, come down, turn, go up, make a little loop or dot; and finish toward the dot." "dec. What letter is it in the middle of the word 'ice'? It is the letter $c$. What does it look like? It looks something like an ice hook, and the $e$ looks as though it were a rope tied to the hook. Do you think you could tie the three letters together with a pencil on paper?" "fay. Lead the pupil to observe that the $y$ contains a $j$, two more strokes and turns in the beginning. Be sure that $y$ has two more turns, one angle and one loop." The downstroke of $r$ is called. "the bend of a boy's knee," and the $o$ 's are "plump and rosy-cheeked!" If the word-picture idea set forth 
above means anything, all such analysis, with its arrant, befuddling association, must be considered the worst enemy of fluent script.

There is no subject in the elementary grades which, in its early stages at least, is so unscientifically taught as is writing. 'The children are at once set to the task of executing the twenty-six letters of the alphabet, - a task which the race mastered only yesterday. 'That the amateur is not ready for this undertaking is put beyond dispute by the contortions of his little muscular system, - contortions which extend from the twisting tongue to the very toes. Could any picture be much more unchildlike? Compare the smiling faces and poised bodies of a group of the same amateur's harmoniously indulging their fundamental muscles in freeflowing motion-pictures, expressing familiar images, feeling the pulse and joy of rhythmic movement. Such writing, however simple, is expressive and educative in the deepest sense, because it conforms to the child's capacity, to his interest, and to the experience of his racial ancestors. It glows with truly childlike creativeness. The fluidity and living qualities which motion-picture writing possesses, and of which all writing ought to partake, elude description. In fact, the suggestions, which we have found rather difficult to put into words, should not be taken seriously by any one who does not believe in the principle that nature desires children always to work by mood and motive. 'The teacher's personality and her own joy of rhythm and easy, expressive motion must be depended upon to give the suggestions their true spirit and full intent. 


\section{CHAPTER XVII}

\section{NATLRE STUDY}

"Pupils study nature in the schools, and when they get out they cannot find her." Such an accusation would be undeserved if nature study began in the primary-school period in first-hand, rapturous contact with living, growing things.

There is nothing new under the sun, but to childhood all is novelty. The most commonplace things teem with novelty. Childhood endows all nature, both animate and inanimate, with motive and character; with fantastic self-illusion even sticks and stones are made to symbolize thought and feeling. Nature becomes the playground of the imagination, and out of this joyous, naïve contact with life spring the deeper sentiments of reverence and faith. Children are in a stage of sense experience when this warm glow of contact through eye and ear and touch may be transmuted into the life of spirit; when light, shadow, sound, motion, and touch weare a tangle of lovely associations around commonplace experiences and build up a deep appreciation of life and things. Thus the truths of nature become unconsciously associated with emotional response, which deepens and safeguards them.

The child learns more through unconscious absorption than through didactic prescription, and in nature study daily contact with the beauty, motive, and unceasing effort everywhere shown by plant and animal gives an impulse to individual character and sets standards of behavior. In nature, science and beauty walk hand in hand. They have not been 
divorced by the pedagogue, to follow separate paths, and facts retain their romantic setting. It is not knowledge alone which counts in life, but knowledge plus feeling.

Primitive man was forced into rich contact with nature, for his daily needs depended upon his knowledge of her moods and products; but the modem child, primitive in all

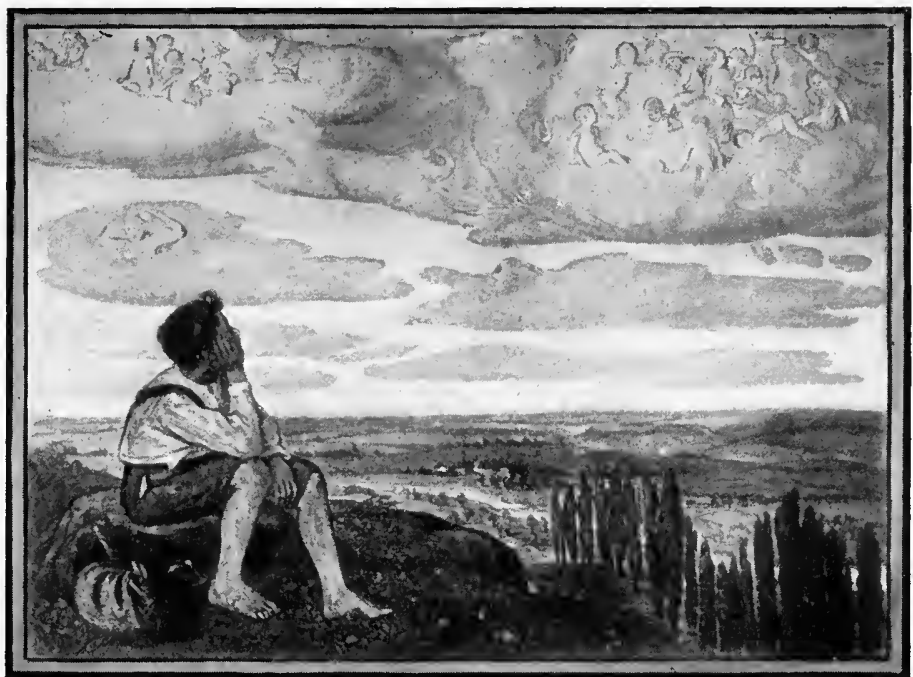

Fig. 52. WOLKENSCHIFFE

(From "Die Woche für die deutsche Jugend")

other respects, is withdrawn from such communion, and he misses both the stimulus and the inspiration when his nature study is made stilted and intellectual.

The child naturally has an animistic feeling for facts. The wind and the rain become the friends of childhood. The raindrops dance like brownies as they patter on the stones outside, or softly fall to give the thirsty flowers drink. The wind howls and sings and whistles, or chases 
the grasses over the meadow. It is well for the elements to play a part in the life of childhood in lighter moods before they are studied as the pregnant forces which mold and transfigure the face of the earth. The child who has felt the wind blowing in his hair, who has watched to see whence it came when it stole his cap away, who has run with it to fly his kite and listened to its rustle among the trees, is better ready to study it in its stemer moods when he meets it as a great factor in erosion or as a motive power in the industrial world.

We miss our opportunities. We give perfunctory instruction indoors when nature is teaching the same lesson far better out of doors; in art, the children struggle with perspective before we have allowed them to feast their eyes upon the lights and shadows under the trees or to watch the colors shimmer and fade in the rainbow, while outdoors lines are falling into exquisite eomposition through vistas of trees and rounded hills, in the curves of the petals of every flower, and in the strength and bigness of the cliffs.

Similarly, the number sense is stifled by notation on the blackboard and not developed by the fundamental conceptions of size, distance, and form in every open field. Number conceptions are born in nature, not in arithmetics. Out of doors the child's sense of direction may be easily trained to a feeling for north, south, east, west. There the relative height of trees, shrubs, and plants, the length of his garden plot, the space between rows of vegetables, establish standards of measure and proportion. The child cannot deal with these concrete expressions of life and motion without constantly making comparisons, training judgment, stating and verifying conclusions; these experiences are the basis of number concepts. The child needs intimate experiences with long, short, round, square, acute, obtuse, big and little, 
not the obtrusive insertion in arithmetics of so-called concrete problems, as, "If I have four apples, and I give two to John, how many have I left? " when the child who works the problem has not had one apple, much less four.

Children are hungry for facts, and no fairy tale can hold a deeper interest for them than the truths of life itself. Nature is at work everywhere, tearing down and building up, and the children may watch her in her workshop. Little children may not understand the term "erosion," but they will listen with rapt attention to the story of how the sand was made, and come to a new consciousness in regard to water, wind, and weather. Animal life, from the tiny earthworm to the bulky elephant, from the grasshopper to the wonder animals of the sea, seems to weave a spell of enchantment for children, and to surpass the cleverest bits of fiction in interest.

They are ready likewise to hear the marvelous truths about the sun, to indulge their imagination in the immensity of its great distance from the earth and yet to know that the sun touches their lives at every point. A study of the sun opens up hours of fascinating thought about light and darkness, day and night, month and year, sunset and sunrise, sundial and shadow; about the effect of the sun upon plant and animal, upon food, shelter, clothing; about its relationship to health and even happiness, and to all the interesting facts of temperature, steam, fuel, evaporation, etc. Besides these truths, for which primary-school children are ready, there is a wealth of material in myth, poem, and folklore which will stir the imagination and charm the listener.

Children feel the wonder and beauty of life; they are in love with it and hold intimate communion with its humblest expression. Nature is reluctant to give them up, and still holds them by the hand to let them share her secrets with 
the birds and flowers. Self-consciousuess has not yet broken the spell, and a child feels himself a part of one great, triumphant burst of life. All the world's akin. The wind talks to him, the flowers bloom and hide for him, the sun sends a shadow playmate to him, and he does not question why. His quick imagination interprets the messages of sight, sound, and touch which greet him everywhere, and the purity of his contact with life fortifies his faith in it.

The child who stands on tiptoe to peep cautiously into the new-found bird's nest, who feels the velvety softness of growing things beneath his feet as he hunts out the tiny wild flowers in the spring, who sows his own garden seed and waits to see the first young green push its way through the dark, moist soil, is building up a reverence for life, a sense of kinship with it, which will uphold him in his later and deeper understanding of its meaning.

Why is it that the little child who bends in hushed tenderness over the new baby's crib, who instinctively strokes the baby cheek as gently as if it were the frail petal of a rose, who assumes at once the attitude of defense and parental protection toward it, often becomes the guilty, inquisitive, unclean boy or girl? Why do children run to meet life with eager purity and go away soiled by the contact? Is it not because we are all afraid of truth; because we give them feeble, foolish makeshifts about life instead of its wonderful facts? We begin, with the perverted interpretations and sentimentality of the so-called nature study in the primary grades, to offer unscientific and inane fairy tales about nature, which degrade the imagination but do not deceive the understanding. Children are poetic, sensitive, and pure-hearted. They are never startled by the truth, but are more logical than we concede, and silently reject what their reason tells them is untrue. The little boy 
of five who said, "I always knew the stork never brought me, for I have n't a peck in my side, have I ?" had become a common-sense skeptic. A failure to give him then and there as much of the truth as he was ready for and the consciousness that he could always find an answer to his questions would have started him upon the unclean path. Nature is frank; she presents a beautiful panorama of life, death, reproduction, mating, and parenthood, and calls the growing child to come and look upon it; the child is ready to take it in with pure eyes, to catch the wonder, beanty, and responsibility of it all, to become the champion of its cleamess and of its health. But instead of such frank contact with nature, which is fundamentally necessary to awaken a true regard for the great facts of sex, he is stopped and blindfolded on the very threshold of his experience; he is given fiction instead of truth, and filled with sophisticated and false ideas of modesty which eventually drive out genuine purity and reverence for truth. The child who has truth confided him as a precious gift will cherish and guard it, but the child who ferrets it out for himself with inquisitive suggestiveness will feel no responsibility for its keeping, but toss it about in boastful grossness. Ignorance is not purity, knowledge is not purity; but knowledge of facts colored with emotional reaction, reverent possession of truth, can never soil the mind. The child who in nature study holds some frail bit of life in his hands and reverently watches its beautiful unfoldment will appreciate and champion its sacredness. 


\section{CHAPTER XVIII}

\section{BUSY-IVORK}

Busy-work occupies an unenviable position in the course of study. Its opponents call it "idiot's delight"; its supporters smile inwardly and regard it as a necessary evil. It is a veritable Cinderella in the educational household, - tolerated because there is no available substitute. Like Cinderella, however, it only needs a fairy godmother to bring it to its own. Properly liandled, busy-work offers endless opportunities for training. What can be done, then, to give it value? It must be so planned that it will give opportunity for independent thinking on the part of the child and enable him to reënforce, by his own effort, the knowledge or skill gained in previous recitations. Busywork must do more than consume time; it must make wise use of it. It must not be administered as a kind of quieting potion, to impress the superintendent when he makes his hurried rounds, but must be full of definite purpose.

Busy-work, to be effective, must conform to certain conditions. It must present a problem commensurate with the ability of the ehild; it must afford sufficient variety to hold the attention of the child; the period of concentration must not be too long; the directions given when the task is assigned must be definite and simple; the results accomplished during the period must be noted by the teacher.

Power develops in proportion to the effort expended. The utter absence of individual effort in an exercise of twenty-five minutes - the time usually allotted to the 
busy-work - is an irreparable loss. Laying sticks to make a pigeon house, which a child of three could do with his eyes closed, represents the character of a large portion of the work. What is the result of such vacuous occupation? Young children are forming habits either of healthful activity, or of inconsequent dawdling, every day that they live. One chief reason why we find a lack of individual attack in study, an inability to concentrate, and a disintegrating languor in the upper grades is the pretense of industry and semblance of study in the first grade.

The child who is not productively occupied necessarily hunts mischief as a relief. He steals a chance to disobey, to talk, or to destroy what he is oftentimes ashamed to have made. When children are allowed to manage their own time you never find them lounging for twenty-five minutes, or languidly gazing out of the window. Natural children keep wholesomely occupied. Their brains and hands are busy. They are plying questions, collecting oddities, or enjoying a well-earned rest. Busy-work often makes use of one tenth of a boy or girl, and leaves the other nine tenths actively in trouble, or humped up in an inert mass of crooked shoulders. On the contrary, the moment a child has a task to perform which is worthy of his effort, what happens? His body straightens up, his blood flows freely to his brain and tingles in his finger-tips. During lazy busy-work the child knows that he is merely being disposed of, that the task imposed is nominal, and that he is not responsible for its completion. Such a state of affairs breeds false conceptions of work.

If you are not skillful enough to plan and direct this period, turn the children out to play vigorously in the yard. They will come back glowing with energy, not crippled with inertia. They will be set for work, not against it. Idleness 
is a habit. The boy or girl who is idle in busy-work will be idle in reading and arithmetic. But, on the contrary, energy wisely expended renews itself and accumulates power, which transfers itself into other lines of effort.

From the teacher's point of view alone, ineffectual busywork means that the child's natural output of energy is being diminished, and that his reaction to the next exercise will be retarded and more difficult. Initiative, perseverance, attention, and enthusiasm are necessary to success. These qualities are being wiped out by accumulated dawdling. They cannot be tapped just for reading and writing, but are the outcome of everyday habit and exercise. The whole problem is one of attitude, - attitude toward school and work until the love of independent effort becomes identified with the child's character. It is a question of self-preservation for teachers to so direct these periods that they will improve rather than injure the working attitude of the children.

We grow to like activities to which we were at first indifferent, because of their association with happy hours. This period should bring to the child a sense of satisfaction in work and achievement. It should excite a pride in the ability to begin and to complete a task without help, so that the child may feel the moral uplift of successful, independent effort. He should form a habit of expecting results and of holding self to account; for the duty of the primary school is to form habits of self-help, - habits which will be useful to the child throughout his whole school life, not habits which will have to be broken as soon as he reaches the grammar grades.

Do not try to force the very young children to study during this period, but give them the organized play material of the kindergarten, - material which calls for constructive 
activity. The little child is so undeveloped intellectually that he needs material full of such suggestiveness that it is easily transformed and will invite expression and invention. See that his problem requires him to compare, judge, and formulate some conclusion. He must learn to think before he learns to study. The mind of the unthinking child will lose its power to organize, and become as inconsequent as an atrophied muscle. How can busy-work be made to meet these requirements?

1. By discarding those boxes of small letters used to spell words, which are thrust at you every time busy-work is mentioned. These letters are enemies, not friends. Walk down the aisle of your room and see them standing on their heads, or pushing into the wrong place in the word, or taking up too much or too little space. You spend fifteen minutes presenting the correct visual and auditory impression of words to be spelled, and then compel the children to spend twenty-five minutes looking at the distorted images which they construct out of these ugly little letters. If spelling must be taught, replace those letters by words and sentences, printed, or written in a bold, free hand. There are many occupations which will reënforce the spelling ; for instance, give every child two envelopes, - - one containing pictures; the other, words which name the objects pictured. Allow the children during the busy-work period to match these on their desks.

2. Make packs of cards, with pictures on one side and words on the other. Encourage the children to run through these packs until they can name all the words without looking at the pictures on the back of the cards. Perhaps they will not be able to do this the first time, but if the children know that they are allowed to look until they can name all the words without such help, instead of an 
effort to cheat there will be an effort to perform the task, and a pride awakened in success.

3. Write a short story on the board (three or four sentences can be made to tell a vital story, full of action and within the children's reading capacity), which the children are to illustrate. Let them copy the story under their illustrations when they have completed them. When this is done they may use the words found in your story to write an original one, which they may also illustrate. 'Such occupation keeps the correct images of words before the children, enforces repetition of words, and incorporates them into the working vocabularies.

4. Have the children tell something which happened on the playground, allowing them to draw pictures when they do not know how to spell the words. These picture stories form a suggestive basis for word study the next day.

5. Children should be allowed to make scrapbooks and to use this period occasionally to paste in pictures that appeal to them. By looking over these books, reading lessons can be formulated about the pictures which will make use of all the "required words," and at the same time insure intelligent rerearling by the children. The children can then review the words contained in the stories by using them to label the pictures in their books. This labeling of objects is natural and childlike, and can be made use of in many ways to enlarge and reënforce the written vocabulary. These scrapbooks will be most individual and reflect the interests of each child; the vocabulary contained in each book will therefore be distinctive, and will increase tenfold the retentive power of the children's minds by conforming to individual tastes.

6. Write a list of suggestive words on the board. The children may make as many stories as they can out of them. 
7. Write simple questions on the board for the children to answer, either with a drawing or in words. This can be made a conversation between the teacher and the children, and is the beginning of letter writing.

8. Draw a picture on the board, and write the necessary words to tell a story about it, in a column at the side. The children must tell the story.

9. Give the children scissors to cut out pictures of words which have been written on the blackboard. Each child must write the correct word on the back of his pictures. In putting words on the blackboard always write the, or a, or an, before them, that the children may be accustomed to the use of the articles and be spared drill upon them apart from nouns.

10. Sentence building, with written or printed words. The stories may be copied from the board by small children, and with the older children they may take the form of original stories about some definite thing.

11. The children should be encouraged to begin dictionaries in the lower grades. Make books that are easily handled and leave wide spaces between the lines. At the top of each section paste, in large letters, one of the word endings, such as ate, and, at, ind, one, etc., and allow the children time to insert under these headings words which they have met in their reading lesson.

12. Use storybooks, provided for the purpose and containing simply sight reading. Set problems for the children to solve; for instance, they might copy all the words which describe winter (or whatever the story is about); all the words that they can draw a picture of ; all the words which tell them to do something.

13. Put simple directions on the board which tell the children to make something - adding a simple diagram 
if necessary. This is easily begun in paper cutting; for instance, "Cut out a horse with a long tail. Cut out a boy and his dog," etc., making the problem more difficult with the increasing power to read and to carry out directions. Whenever the reading can be made a mears of real communication between teacher and pupil, it adds motive and interest. Children should not read just to let their teacher know that they can recognize the words by sight.

14. Directed handwork where the children have a piece of work to do and know how to do it. Purposeful paper folding, paper cutting, free-hand sewing, stringing nature material, cutting patterns, or making designs for a definite purpose. Bring into the first grade as much kindergarten material as you know how to make use of, and set a definite problem, in keeping with the child's capacity. The few moments which it takes to plan and start the busy-ivork are well spent. A child should know that he will be held responsible for his time. He should work honestly or else rest completely.

From the very beginning of school life the children should associate the classroom with happy, energetic work, and never with languid, waiting listlessness. Little children are not able to do much studying alone; they have neither the capacity nor the incentive. Much effort must be given then to plan these periods, and to see that the children are gaining and not losing in the power of independent application. The word "study" should be frequently made use of in talking with little children, and in connection with a variety of interesting problems, so that they may not associate study with an uninteresting, dog-eared book, ont of which all the juice has been extracted. "Study" means "attack"; it means the solution of delightful problems in handwork, reading, dramatic play, 
and games. If such terms as "Think it out," "Find a way," were used interchangeably with "study," little children would begin their school life with a clearer idea of what it means to study. It is natural for a child to enjoy study if study means the solution of a problem. Children take a delight in success, whether it is in the classroom or on the playground.

The business of the primary grades is not to give information, but to teach the children how to get it. 'To teach them how to work independently is of more importance than to teach them the technique of reading. The grammar grades and the high school need pupils who can think; they have plenty who can memorize words. But they will continue to be surfeited with lip workers until the primary school agrees to train the thought powers of the child, until it makes use of its rare privilege to form happy associations in his mind with "study" and "work." 


\section{CHAPTER XIX}

\section{OUTDOOR PLAY}

There is in the elementary school a serious lack of the right kind of wholesome exercise for the younger children. The same pedagogy which applies to the intellectual work of the primary-school child should regulate his exercise. Just as formal drill and technique in the presentation of subject matter stultifies the deepest instincts and potentialities of the child's mental life, so perfunctory, formal gymnastics impede his physical development.

Children need spirited, playful, imaginative, dramatic exercise which makes a demand upon their whole nature, - exercise which utilizes in an instinctive way the large, muscular masses that effect respiration, digestion, and excretion, which tone up the whole body through graceful, childlike abandon. The child's desire for play leads him unconsciously into an active, spirited, rhythmical use of his large, fundamental muscles. Rhythm is a loved impulse in child life and, if incorporated into his exercise, will lead to grace and artistic delight.

The kindergarten catches the child in the midst of this fluent, rhythmical expression, and lends a hand in rhythmic dances, ball plays, tiptoe games, and imitative and imaginative exercises. So far so good ; but what of the primaryschool child, who is running over with the same deep tend encies and love of rhythmic play? He is cut off from this expression and is too often allowed only the rough, unorgan. ized play of the recess hour, or the perfunctory shifting of 
arms and legs to the solemn "up, down, up, down," of the tired teacher. For the lack of organized, spirited, dramatic play the primary-school child settles back on his heels and loses his innate buoyancy and grace.

The young child loves life and motion. He can fly like a bird, hop like a frog, run as lightly as the quail. He has a reverent interest in the earth, and likes to imitate and understand all the industries and activities around him. He will dig, plant, and rake. He will build, climb, jump, run, and skip; he is rersatile beyond all expression and needs only the suggestion of his environment, coupled with the childlike wisdom of an understanding comrade, to supply him with the truest and happiest exercise of his whole body.

Why should the primary-school child. as soon as he leaves the kindergarten, be denied the inspiration of the piano? Why should he not continue to hear and express a variety of rhythmic moods? He is still a kindergarten child at heart and loves to march, run, skip, fly, dance, and swing to the persuasion of musical accompaniment. His exercise should continue to be joyous, graceful, free, exhilarating. unconscious. He cannot get it on the streets nor in the modern home. He must get it at the schools if he is to claim his proper heritage.

The child tingles with definite muscular coördinations: movements which have been of use to the race in its struggle with nature survive as pregnant tendencies in his neuromuscular machinery. Folk games, rhythmic plays. and dances call these into action and set the whole body of the child into sympathetic vibration. The grmnasium of the primary school should therefore be a covered outdoor pavilion with a piano and plenty of light and air. The children should dance, sing, march, walk, with vital step. They should play with balls, - big balls, little balls, balls 
to roll, to toss, to bounce, to throw into a bottomless basket. They should climb ladders, roll hoops, fly kites, toss bean bags, knock down tenpins, and play a variety of selected folk games, with their mimicry and suggestion.

In a suggestive sentence in his book on "Age, Growth, and Death" Minot says: "When a cell is in the young state, it can grow rapidly; it can multiply freely; when it is in the old state, it loses those capacities, and its growth and multiplication are correspondingly impeded; and if the organization is carried to an extreme, the growth and the multiplication will cease altogether." Outdoor play, with its balanced, graceful, childlike use of the body, will create a reserve fund of energy, a deep well of health, from which the power to function accurately may be drawn later. But the child who substitutes organized physical drill for these more wholesome exercises is differentiating cells, not multiplying them; he is wearing out his muscles prematurely, not building them up.

If young children lived in an ideal atmosphere, where there was no interference with the wise plans of nature, the question of exercise would solve itself unconsciously in play, for play is the guardian of the child's physical health and furnishes the normal stimulus to the various organs and nerve centers of the body; but modern institutions, both social and educational, impose false conditions, and we must consciously set about to correct the complications we create. We must use certain definite grmmastic exercises to correct contracted chests and invite the respiratory organs to take in their normal quantity of oxygen. We are responsible for the bad postures and sluggish circulation which follow poor ventilation and confinement. We must therefore start the blood flowing naturally by the use of corrective, formal gymnastic exercises. But even these 
must be enjoyed with spirit and laughter if we would accomplish results, and the amount of time given to such work depends upon the gravity of the false conditions which you yourself permit in your own classroom.

The startling results of the open-air schools have convinced us that growing children are as dependent upon pure air as upon wholesome food. But we are victims of an indoor habit, and it takes comrage to be true to our convictions. A good way to begin, however, would be to oxygenate the primary-school child by holding every pos sible session outdoors, and by turning him out to play whenever the indoor busy-work proves unprofitable. Educate his sense of smell and respiratory organs so that he will rebel against confinement in a close, ill-ventilated room as he would against a shoe that pinches.

Children would return to their work vitalized and buoyant if short out-of-door intermissions were encouraged. It is conceded that we are a nervous, irritable people. One of the prime causes of this undue nervousness is a lack of oxygen. As certain chemical experiments go to prove, the nervous system, perhaps more than any other organ in the body, requires oxygen.

For many reasons children need short, intensive periods of work interspersed with many intermissions for fresh air and play. Dr. W. H. Burnham, in his article, "The Hygiene of Physical Education" (American Physical Education Review, Vol. XIV), says: "From the point of view of hygiene the aim of physical training is the development of habits of healthful activity (using the word 'habit' in its broadest sense) : habits of digestion, excretion; habits of storing and expending energy; habits of coördination and control; and even the reflexes of the sympathetic nervous system, as well as the reactions of the central nervous system.... 
Hygiene demands special consideration of the development of four of the most important organs of the body, - the heart, the lungs, the digestive apparatus, and the nervous system. ... The natural form of lung gymnastics is free play out of doors.... If the lungs are not developed properly in early life, the defect is not likely to be remedied afterwards." Again, Dr. Burnham says: "The consensus of expert opinion is to the effect that the best means of developing the fundamental nerve centers are the various forms of free play; and it is noteworthy that nearly all the movements made by children in their spontaneous plays are those involving these centers, and that the accessory movements are rare and few in number. . . . Plays should be recreative and should not stimulate to great nervous discharge."

A child should never use his muscles languidly, but with the intoxication of delight, if he is to benefit by that use. G. Stanley Hall says: "Muscles are in a most intimate and peculiar sense the organs of the will. ... Character might in a sense be defined as a plexus of motor habits. . . Skill, endurance, and perseverance might almost be called muscular virtues, and fatigue, velleity, caprice, ennui, restlessness, lack of control and poise, muscular faults." Should not this truth cause the primary school to look to the normal muscular health of its children? Is it not a commentary upon civilization to read that savages are superior to civilized man in correct or resthetic proportions of the body? The savage uses his body in fluent expression of his emotional life. "The psychomotor impulses which prompt play are the forms in which our forbears have transmitted to us their habitual activities." The child who is denied the expression of his play instincts never comes into his heritage of bodily and mental health, but is the victim of 
the nervous irritation of inhibited tendencies. Play will neither allow the muscles of the body to become flabby nor develop them in technical skill, but will establish that balance between exercise and rest which results in a harmonious growth of all its parts.

The child's mood is king, his body only the servant. Turn the pages of Gulick's delightful book, "The Healthful Art of Dancing," and catch the contagion of its joyous illustrations. Happiness is the vitalizing energy of child life. It will chase out all idleness and listless awkwardness, and set the body in harmonious accord. The lovely children dancing on the roof in Gulick's book are expressing vibrant joy, and their bodies have taken on elasticity and charm. What we need in all of our work is this enticing spirit of the dance, glowing abandon, unconscious loveliness. Childhood's veins are full of it, and free outdoor play and the rhythmic folk dance will perpetuate it to the race. 


\section{CHAPTER XX}

\section{MORNING; EXERCISES}

Look at the beginning of any piece of work and you can foretell the character of its end. Attend the morning exercises in any schoolroom and you can predict what the day's work will be.

Children of primary-school age are forming attitudes toward work and play, toward life as they live from day to day. They are piling up fundamental experiences, each one of which will leave behind it an emotional tone. The sum of these experiences and responses constitutes character, personality. As a child thinketh, so is he, and the response to the morning exercise becomes the child himself. The variety of his impressions and the spontaneity of his responses establish habitual reactions and habitual attitudes and points of view. A child is different who has these brief expressions of joy or sudden moments of conscious seriousness, or who cannot refrain from bursts of wholesome laughter.

Variety in emotional expression is as necessary as variety in diet, and the morning exercises afford the opportunity for such variety: The child is more alert, more sensitive, more plastic in the morning. He has not yet fixed his day's attitude by unfortunate omissions. He is susceptible to impressions and suggestions. The frankness and informality of the period invite individual expression and necessitate individual contact. The morning exercises, then, should be full of variety. This is why we do not sanction the reading 
of one continued story. Such work is more advantageously presented during the literature period. Undoubtedly the children will be interested, but they are intent upon a narrative, an action, receiving for the most part only one impression. The morning exereises should start a variety of impressions, touch upon a number of suggestive experiences, call out individual expression, and give the children many points of view. Small bits of verse, such as one finds in the "Posy Ring," or "Tree Tops and Meadows," make such a course possible. Read four or five lines of a serious sort, then a line or two of laughter, then a bit of pure rippling nonsense sound, then the odd bits which reflect the consequences of familiar childlike faults. These are impersonal, and, because they are not consciously aimed at the erring boy or girl, excite deeper reflection.

"Morning exercises," then, is the time for a kind of touch and go, - a dropping of hints, convictions, suggestions, and comments. It is the time to fire the imagination and loose the spirit of childhood. We are sometimes too much concerned with what is in the minds of little children, and too unconscious of what is in their hearts. Look into your children's faces; know the habitual expression of each one, that you may have a starting point for persuasion and development.

Know the habitual physical expression peculiar to each child, for there is a normal physical tone reflected in body and mind. Watch its variations, that you may attribute unusual conduct to unusual conditions. If you know the physical and mental tone of each of the children, - the expected individual reactions, - it is easier to account for and to correct discrepancies. The lack of breakfast, lack of sufficient sleep, or the resultant irritability of a nervous hurry to school will utterly demoralize the best child. If the 
teacher does not recognize these artificial conditions, and find an opportunity to establish the child's habitual reactions by a moment of composure, rest, or food, the work of the whole day will be disfigured.

Sometimes a child's mood or mental state must be changed by the morning exercise before he can work well. Perhaps, before he left for school, he was roughly handled at home, or he has been teased on his way by some older boy, or he has met with some accident to book or toy or clothes. These are trivial sorrows from our point of view, but they can make the world a desolate place for a child to live in. The emotional tone which these unfortunate experiences have established must be driven out, and a hopeful, selfconfident, working attitude let in. The boy who failed yesterday must feel success to-day, if it is only by telling a short experience or by showing some cherished toy. Toys are precious possessions which are tied to children's hearts. The boy who shows his gun, and the girl who shows her new doll, lets you into secret places, and throws the barrier down. One can slip into a young mother's heart by feeling an interest in her new baby; one can slip into a child's heart by frank enjoyment of his toys. It is all possession, after all, and who would not possess a little new wagon or a shining gun! These are the intimate, personal possessions of childhood, which bear the stamp of the owner. If you cannot without self-consciousness roll a hoop, spin a top, or croon a doll to sleep, you have never learned the language of childhood, and you are a stranger in a foreign land.

Little children are delicate instruments, and they must be delicately handled, that their sensitiveness and possibilities may balance one another. Children are individualistic, personal, intimate; the teacher of children must enter into these experiences and imaginations of selfhood. She cannot 
deny children intimate contact if she would be of any service to them. The first fifteen minutes of the day is the time for such contact, - for companionship, unconscious direction, and subtle suggestion. It is the time to bring into the classroom the sunlight, the freedom, and the naïvete of the outdoors. It is the time to start observations, questions, and reflections. It is the time to set definite problems of self-government, and to establish a tradition in the room which will become like the air one breathes, and which will be the pride of every individual.

Where it is possible, assign a few morning tasks; a committee allowed to come in before school to look things over, to fix the erasers and chalk, to feed the pets and water the flowers, takes on a pride of ownership and responsibility which establishes moral attitudes. Let it be a privilege to contribute to the general comfort in this way, and allow no one's name to appear on such a committee who has not a good weekly record.

The morning exercise is the time to establish standards of cleanliness, and persistence in good physical habits in regard to sleep, food, and elimination. It should foster respect for private property, a pride in ownership, and a measure of personal responsibility toward the general conduct of the school. Every child should have a pride in being dependable and self-reliant. These are the things that build the morality of childhood, and all the preaching in the world will never make up for the unconscious influence of the teacher during this period of intimate confidence.

Children need ideals, not punishment. It is the teacher's fault when the boys and girls are dirty, slouchy, and generally unkempt. The boy who knows that there is some one who will look for and expect clean hands and face soon sets a new ideal for himself. A crooked part in the hair, 
and islands of dirt still clinging around his eyes and nose, will testify to his first conscious struggles. It is worth while for the teacher to be vigilant, for the beautiful, clean boly is.a safeguard against an unclean mind. Make a standard, then, for the children to live up to, - not a rule but an icleal, - and watch the crude scramble to reach it. You cannot command children all the time, but you can by suggestion, interest, and encouragement set the tide of a whole room surging toward a desired end. The dirtiest boy in the room will astonish you some morning by appearing desperately clean, with a flower in his buttonhole.

Little children must be led to the fulfillment of their possibilities through a firm faith in the unselfish affection of those who care for them. The child is controlled by love. He understands love, for his heart is running over with it. It is incorporated into his being, for it was the force which first gave him life, and it is the energy which will continue to drive him on to excel himself.

The briefness and the informality of the morning exercise make it a tremendous influence in the life of the child. Pedagogy cannot be measured by hours or minutes, for a child often develops more in a moment of joyous personal contact than in hours of conscious teaching. 


\section{CHAPTER XXI}

\section{DISCIPLINE}

After all, what is discipline? It is not rule, rote, and silence, but the establishment of a working attitude in one's classroom. What is disorder? It is only that which interferes with the progress or the comfort of any member of the class.

To maintain discipline (and according to the definition above it is absolutely essential to success) one must first study the health of the children. Discipline, if analyzed, would be found to include ventilation, light, heat, rest, and cleanliness. Discipline is unconsciously affected by environment; even the appearance of the room is an item of concern. A vase of beautiful flowers arranged with an eye to color and proportion may be made a source of control. Children are deeply sensitive to their surroundings, and may absorb disorder and irritability both from the teacher and the general atmosphere of the room in which they work. Orderly mental habits hover over the boy or girl who has orderly physical habits, and, other things being equal, the clean child in the clean, attractive room will be well behaved.

The apathy of the average classroom creates first a negative attitude and then open rebellion. Good discipline is a question of attitude. Children need positive direction, and the undirected pretense of study in the early grades, before the children are capable of independent study, is the breeding ground of discontent and immorality. We are forgetting that it is not learning how to read that counts, but learning 
how to think and to study. The study periods of the primary-school child should be wisely directed, for the ability to study is the foundation of all later intellectual progress.

Obedience is not a birthright of children. It is not like the gold or silver spoon put into the mouth, but eomes to them slowly, growing as they grow, until it becomes habitual to be law-abiding. Disobedience, likewise, is not inherent. It is frequently a good impulse turned in a wrong direction. Many children are not intentionally disobedient, but have a career of carelessness which results in absent-mindedness, a negative attitude toward obligations, and a general moral incapacity. Such a child can be made obedient only by a patient rebuilding of habits. One should not put the same exactions upon him as upon the child who comes from the orderly home. The latter has absorbed the power to obey with his mother's milk. Regular physical habits of nourishment and sleep have laid the foundation for his orderly moral response. The other child must undo the habit of five or six years of shiftlessness, to take on the habits of order and control. Only the wise and sympathetic teacher can help him to do this. He must be led from one success to another, with a consciousness of victory that is pleasurable. The habitually disorderly child, who is plunged into the school routine and expected to respond to all of its regulations at once, feels a sense of defeat that results in an antagonistic attitude toward school and hampers his progress. We are learning to grade children a little more wisely according to their mental power, and we must now learn to grade them morally.

The conventional morality of childhood is not a thing complete in itself. It is, after all, only the past habitual response of the individual to law and order. It is the result of training, not of inheritance. The child who comes to school unruly must therefore be looked upon not with dislike but simply 
as deficient. He should be treated with the same consideration as the child who has missed a half year by sickness, or who has been moved about from place to place and is behind his grade in specific subjects. Make the problem in discipline for the individual child within his capacity, just as you do his reading or writing lesson; then see that he solves it.

Moral power must grow as mental power does, with the opportunity to use it. The gospel of good discipline lies in first making the child willing to do the right thing. The teacher's will, however strong, cannot control the child's conduct; he must do that himself, and he will do it if he is permitted to see that good conduct is a personal possession that works to his own advantage. Children's standards are not altruistic; they are guided by consequences, and legitimate punishment should deal with such personal and practical consequences.

Children are considered disobedient when there is absolutely no conscious desire to disobey. A whole army of disorderly habits, laying siege to motor impulses, must make disorderly behavior automatic. The study of the psychology of habit opens our eyes to the fact that disobedience is as reflex in some children as their respiration.

Again, many children are hard to control because, in a kind of self-defense from inopportune and incessant correction, they have learned to close their ear traps and shut out all remonstrance. They frequently do not hear directions and suggestions. Commands do not penetrate their central nervous system, but merely slide along that proverbial path from ear to ear. Obedience is then often a mere matter of concentration, attention ; and if you will observe the disobedient child at his work, he is equally unable to concentrate there. The question is, then, What kind of correction does he 
need? Does he need to be punished for individual offenses, or does he need to be trained to concentrate? The solution lies in training. Many a child, tanght to apply himself in independent study, is made thereby obedient.

The moral law of childhood is physical, social, and personal. It is a question of habit, public opinion, and personal application. You cannot train the moral impulse of a child abstractly, any more than you can train his intellect so. Moral training, like mental training, must be concrete, daily, by example and practice, beginning with small victories and learling toward larger responsibilities. Many of the children, before they come to school, have never had a definite required task. Surh children need immediately to be given the charge of some school pet, or the care of some article in the room, that the task, however simple, may require daily attention and give concrete, daily evidence of any"neglect. The effects of the child's play life lave been immediate, visible. He has a basis of judgment in regard to it, and forms his likes and dislikes accordingly. Now the results of his daily living must be visible, personal, immediate, if he is to grow in moral perception.

Look to the moral capacity of the individual child when you discipline lim, just as you do to his mental capacity when you grade him. He must be led from the spot at which you find him, and cannot be forced to leap over the intervening space by the whip of discipline. Even if fear forces him to cover the ground, he will backslide, for there is no sure foundation beneath his feet.

Imitation and suggestion are the avenues of approach; commands, when these fail. Much of the disorder and unrest in the classroom is due to the teacher's instability, unevenness, and unsteady hand. The demands made of little children must be steady, invariable, and progressive, 
that by much repetition the children may acquire fundamental and habitual responses. Children have learned to read and write by repetition; by the same process they must learn the personal habits that constitute morality.

Children have little morality so-called. They are as indifferent to the social sins as they are to offenses against language forms. The only difference is that we recognize the latter and proceed to awaken a language conscience through an appeal to the sensitive ear. We must recognize the former and awaken a moral conscience by a persistent appeal to the heart and mind of the child.

The man who told his boy that at 10 A.M. the following Wednesclay he would give him a sound whipping for some offense committed was extreme, but he offers a suggestion. Children cannot be corrected with effect when their whole body is vibrating with anger and the motor impulses are necessarily too strong for resistance. That intensity of feeling must be given time to spend itself and a normal functioning be resumed, if reason and kindliness are to be substituted as motives. Many a kicking, screaming child, allowed time to go apart, to wash his face, to sit alone awhile, will return docile and open to conviction. Healthymindedness must be allowed to assert itself before correction or punishment is put in force. Emotion lies close to the will, and the child must be led, by love and suggestion, to the development of standards of choice which reason can formally support and the will execute.

It is necessary that a teacher who would understand her children should follow them to the playground and there study their temperamental reactions. She will get insight that the classroom will never afford. On the playground the friendships which are the sources of temptation become apparent. Perhaps two children with exactly the same faults 
to overcome have been sitting side by side in school, each fortifying the other in weakness. A change of position in school hours is often the ounce of prevention that brings a pound of cure. Again, certain children with individual peculiarities antagonize one another. Incompatibility of temper exists between certain natures, and persists, do what you will. One cannot expect a child to come to his first experiences with such incompatibility, steeled in self-control. He should not be made conscious of these differences in temperament, but the wise teacher will not leave unnecessary sources of irritation in the way of little children, any more than she will wear a pebble in her own shoe. The child's heart is stocked with love, joy, helpfulness, faith, wonder, fear, anger, and love of power. These instinctive reactions, so evident on the playground, should form the basis of discipline and control, - each in its due proportion, for the task of education is to assist and patiently wait for natural development.

The formality of the average classroom encourages disobedience. The teacher who overburdens the children with rules and regulations invites rebellion. A natural impulse toward order is frequently inhibited by too much prescription. Some well-meaning teachers, by too much negative suggestion, call out a new list of juvenile offenses every day. There is a strain of perversity in human nature which, if provoked, swells into obstinacy and armed resistance. Beware that you have your class with you and not against you, for children catch the mood of their companions and are very versatile in their ways of signifying it.

Social coöperation and hygienic living will do more to provoke moral energy than all the punishment that can be devised. But social coöperation means a wholesome emotional response, not silence and constant repression. 
Emotional response is as necessary to moral growth as the circulation of the blood is to physical growth. To secure this wholesome emotional response, however, some changes must be made in the school routine. First, we must put an end to the nervous competition and struggle for existence, which begins even with the babies, and which develops insistent selfishness. For instance, it means doing away with spelling lessons beyond the children's capacity, which lead to the first successful misrepresentations, to untruth and aggressive selfhood. Wit and shrewdness count for suceess in the struggle for life. In the average classroom, with its system of rules and tests of knowledge, the struggle for existence is as keen as in the animal world. What wonder, then, that the shrewdness and mother wit of childhood step in to win success at the expense of fair play. Neither in the animal nor in the child is there conscious morality; survival of the fittest is the watchword, and the animal steals the coveted bone as naturally as the child looks on his neighbor's paper. Children, by the severity of the requirements in school, are put into temptation before they have been taught to discriminate between methods, or have established an ethical relation between means and ends. What wonder that they use the most expeditious way.

Why should we expect such sensitive moral choice without the long experiences out of which choice is born? Is choice in form and color so evident? Go into the homes of the untutored and look at the combinations of color. 'Their' eyes are not offended by them; their choice is made without experience to guide them. Follow the American public in its choice of Christmas presents, and draw your own conclusions. Why should we delude ourselves into thinking that moral choice comes ready-made any more than standards of beauty in color and form? 
One more suggestion, simple but often neglected: much punishment would be avoided in the primary school if teachers were more sensitive to the signs of approaching disease. Mumps, for instance, disfigures a child's behavior long before it does his face.

There is a psychological attitude toward the problems of discipline which will be a comfort as well as a service to the teacher. It will make her point of view impersonal and interpretative. It will induce less restraint and provoke more freedom, for discipline that depends upon desks that are screwed to the floor, and an orderly arrangement of chairs, does not promote moral health.

Children work with their whole bodies and should be encouraged to take easy, natural positions, for the more mobile their bodies, the greater their power of absorption and expression. The atmosphere of a classroom, however, is a subtle thing and depends largely upon the temperament of the teacher. Even in the most modern kindergarten, where there are tables and chairs and plenty of space and sunshine, one may see the most pitifully orthodox behavior. The great teacher is superior to her equipment and projects her spirit into the conduct of her room. She knows how to establish a working attitude which will awaken spontaneous attack and keep every child occupied to his fullest eapacity.

The word "discipline" should be construed to mean "nurture"; that is, the care and sustenance necessary to physical, moral, and mental growth. Such a conception of discipline would allow the children a natural, fcarless expression of body and mind. It would establish a homelike atmosphere in our schools, which would result in definite benefit to both teacher and pupil. The average teacher needs a freer environment to persuade her to relax, and 
when architects and building committees use more courage and ingenuity in the construction of our school buildings, we shall have less difficulty with discipline.

In conclusion, then, the moral life of children hinges upon the subtle influences of daily living. The good cheer, the unselfishness, and the general moral tone of the home and the school slowly and certainly build up the moral fiber of childhood. The child's standards of right and wrong are not formed to-morrow, but yesterday and to-day, out of the joys, sorrows, duties, sacrifices, and companionships of daily living. Social contact builds up a sense of honor and a legitimate pride which all the formal ethics in the world camnot instill. 


\section{PART FOUR}

\section{THE CONSERVATION OF CHILD LIFE}

\section{CHAPTER XXII}

\section{PESTALOZZI AND HOME EDUCATION}

Following is a passage chosen from Pestalozzi's greatest book, "Leonard and Gertrude." Arner, the magistrate of Bonnal, in company with the Lieutenant, is standing on a high mountain, from which he views his domain.

"The placid Itte which flowed at their feet was shimmering in the purest silvery light; the sun was sinking, and the liquid mirror of the sinuous stream glittered from the village of Bonnal far out to the end of the blue mountains, which, like a great curtain, shut off Arner's land from the world beyond. For a while Amer contemplated the scene in silence, and then abruptly said, ' $\mathrm{Ah}$, mankind is so ugly, and no matter what we may do for men we can never bring it to pass that they will ever be beautiful as is this valley'; and the spectacle of the valley in the sunset was indeed a glorious one. 'But that is not true,' objected the Lieutenant; and as he spoke there appeared, at the base of the rock on which they stood, a shepherd youth driving before him a poor, lean goat. He stopped still at their feet and looked off toward the setting sun, leaned upon his crook, and sang an evening song. He was the very image of beauty, and mountain and valley, 
the stream and the sunset, vanished before their eyes, for now they saw only this ragged shepherd boy, and Amer said, 'I was wrong. The beauty of man is the highest beauty on earth.","

This passage, which is even more beautiful in the original German, transports us into Switzerland, gives us at once a glimpse into the poetic and perhaps somewhat sentimental soul of its author, and strikes the keynote of his character. When Arner says, in the presence of the sunset and the mountains, that there is nothing nobler in this world than man, he is speaking for Pestalozzi.

In one of his letters Pestalozzi himself says, "I looked with armiration from the height of Gurnigel upon the immense valley with its mountain border, and yet at that very moment thought more of the badly instructed people it contained than of the beantiful scenery. I could not, nor would I, live without accomplishing my aim."

This is more than mere emotional vaporizing, for the whole life of Pestalozzi bears out his words. He had an enthusiasm for humanity, and he lived out his idleas. He simply could not hold his instinct of brotherhood in check, and herein lies his genius. If genius is insanity, we shall have to express it this way: he was a monomaniac dominated and swayed by one impulse, - love for his fellow man; he had one fixed idea, - the regeneration of humanity ; and if it was a case of delusional insanity, he had one persistent delusion, - a faith in the educability of mankind.

Indeed, during his lifetime people more than once doubted his sanity, and predicted that he would end his days in a madhouse. Others who were more charitable explained that he engaged in the menial trade of schoolmaster because he had fallen into poverty. At any rate, before he died, even such conservatives as kings and 
princes recognized something of the sanity of the great ideas that were announced by this peculiar-looking, peculiar-acting Swiss schoolmaster, with that strange-sounding Italian name, and to-day almost all the world is ready to assent to the epitaph inscribed above his tomb:

Here lies Heinrich Pestalozzi

Born in Zurich on the 12th of January, 1746

Died in Brugg on the 17th of February, 1827

Savior of the poor at Neuhof

Preacher to the people in "Leonard and Gertrude"

Father of the fatherless in Stanz

Founder of the new elementary school at Burgdorf

and Münchenbuchsee

Educator of humanity in Yverdon

Man, Christian, Citizen.

Everything for others, nothing for himself.

Blessings be upon his name.

This epitaph recalls the landnarks of a long, active career of eighty-one years. Pestalozzi lived in an age that literally teemed with great men, ideas, and events. In America the struggle for individual freedom was largely political and culminated in a revolutionary war. It expressed itself in the self-evilent phrases of Roussean's philosophy, a philosophy destined to be the mouthpiece of another revolution still more comprehensive. In Germany there was a peculiar little man, about as large as Pestalozzi, by name Immanuel Kant, who shed tears of joy over these two revolutions, - the one in Paris, the other across the sea, - and constructed a philosophy which itself was profoundly revolutionary. This philosophy, if it did anything, emphasized the dignity of the individual and the possibilities of his creative self-activity. Fichte, the earliest exponent of Kantianism, and personal friend of Pestalozzi, declared that Kant's philosoplyy coincided exactly with the 
fundamental principles laid down in "Leonard and Gertrude." There was much sympathy among the great men of this period of Aufklärung.

But, marked as was the intellectual activity in Germany, the awakening in Switzerland during the last half of the eighteenth century was, if anything, more brilliant. Tremendous powers were concentrated on Swiss soil during that period. Rousseau, a native of Geneva, after his "Émile" had been publicly burned by the hangman, fled to the Swiss Alps. Voltaire also found a retreat there. Edward Gibbon completed his great history in Lausanne. Madame de Staël held an intellectual court in a castle on a Swiss lake. Kleist, the Swiss literary scholar, could write, in 1752 , "Whereas in great Berlin there are not more than three or four men of taste and genius, in little Zurich there are twenty or thirty"; and Zurich, be it remembered, was Pestalozzi's birthplace and college town. The doctrine of the simple life, and the Wolffian philosophy, which preached a return to nature, were in special favor at Zurich, and found ardent disciples at the university. Breitinger and Bodmer, the advocate of republican liberalism, were two inspiring teachers, and gathered about them groups of eager students, Pestalozzi among others. Sometimes they would all assemble as a revolutionary organization called the Helvetic society.

In this feverish, utopian atmosphere Pestalozzi lived out his adolescence. It must have been a congenial atmosphere for his ardent soul. Even as a lad he had shown a precocious reforming instinct. When a mere boy he was impressed by the good deeds of his grandfather, the village pastor, and announced, "When I am big, I am going to be a pastor too, and side with the peasants." And so at the university he studied theology, but fortunately broke down 
in the middle of his trial sermon. He then decided in favor of law, promising to help the peasants in the court, but this also did not suit. Next he turned to the Jeffersonian ideal of agriculture, hoping to show what the sunken peasants might do for themselves in the noble art of farming; but as a practical agriculturalist he only registered another failure. His friend Schinz has an explanation: "who in his thought at the stars stumbles into a quagmire at his feet, who can neither talk to nor act with any of his fellow creatures without offending them with his unpleasant exterior and his uncouth, disorderly ways, - how ean such a man ever hope to be able to get on in actual life." As it was, Pestalozzi wrote in his diary, in 1775 , "The dream of my life - the hope of making my house the center of a sphere of benevolent activity - was gone."

But in reality this dream was just about to be realized, for no sooner had his agricultural project fallen flat than he converted the roof above his head into a shelter for neglected children, thus finding, for the first time, adequate expression for his philanthropic passion. He started at Neuhof the first industrial pauper school known in history.

But how explain this strange, unheard-of notion of opening the door of your own home and gathering in all the vagabonds from the highways? Why under the sun should a bankrupt farmer who cannot keep himself out of poverty presume to take care of other paupers? This very proper question receired very especial emphasis from the relatives, the neighbors, and the prudent generally. Even to-day it is an eminently pertinent question for the student of Pestalozzi, and De Guimps is right in seeking the answer in the fact that four years before this a son had been born to Mr. and Mrs. Pestalozzi. They shed many tears of joy at the event, and in his diary the father makes 
this entry: "Thou God who hast made me the father of an immortal soul . . . send me Thy spirit from on high. Give me now new strength, create in me a new heart, fresh zeal, oh, my son, my son!"

The experience of parenthood worked a revolution in Pestalozzi's thinking, leading him to realize the significance of childhood for the individual and society. In the light of that new realization the opening of the pauper school at Neuhof is comprehensible. Though the undertaking outwardly failed, it was in reality a deep success. After five years' association with the children, Pestalozzi said: "I knew the people as no one else did, and I never was more profoundly impressed by the fundamental truth on which I had based my efforts than when I saw that I had failed. I have proved that children, after having lost health, strength, and courage in a life of idleness and mendacity, have, when once set to regular work, quickly recovered their strength and spirits and grown rapidly. I have found that even the most depraved of them are touched by kindness."

Nenhof must be considered the most Pestalozzian insti. tution he ever managed. Here he could be as he wanted to be, a father to his children. He clothed them, fed them, and treated them in every way as his own. There were some fifty of them in the family, ranging from four to nineteen years of age. De Guimps's description follows: "They were always with him, sharing in the work of the field and of the house, and in bad weather spinning cotton in a large shed. Very little time was given to actual lessons. Indeed, the children were often tanght while working with their hands, Pestalozzi being in no hurry to teach them to read and write, convinced as he was that this is only useful for those who have learned to talk. He gave them constant practice in conversation, however, on subjects taken from their 
everyday life, and made them repeat passages from the Bible until they knew them by heart." It must have been a very unconventional school, headed as it was by a schoolmaster so unconventional that he slighted the three R's and went about chewing the end of his necktie.

Bankruptey and derision could not shake his faith. The very year of his failure he began to publish his convictions on the subject of education. "Evening Hours of a Hermit" and "Leonard and Gertrude" appeared in close succession. Zschokke says of the latter, "Everything that he afterwards wrote-yes, his whole life - was but the expounding and explaining of this one book." And indeed, Pestalozzi, although he had fifty years yet to live, never got far beyond the principles embodied in that great, true novel. It will therefore be unnecessary for us to trace a course of progressive development throughout his long career, for there was none. He held fast to the fundamental conceptions of his early manhood.

And what were these fundamental conceptions? They are not, as a rule, satisfactorily stated, for Pestalozzi has been interpreted altogether too much in the terms of our own conventional conceptions of education and of the supposed influence he has had on the course of its development. Ordinarily it is believed that Pestalozzi advocated love between master and pupil, observance of the order of nature in teaching, sense perception as the basis of instruction, and popular education. But all of these things, so far as they mean anything, are bound up in and subordinate to one idea, - the idea that was so unequivocally expressed in the aphorisms of "Evening Hours of a Hermit," and which is also the underlying conception of "Leonard and Gertrude." That one supreme idea is Pestalozzi's idea of the home. 
We have his own words: "A man's domestic relations are the first and most important of his nature. . . The home is the true basis of the education of humanity."

These two aphorisms, taken from his first educational treatise, were never contradicted, modified, or retracted by Pestalozzi. They represent the true explaining principle of all his subsequent teaching. The very titles of his writings furnish evidence of this :

1. "The Instruction of Children in the Home" (an early unpublished writing).

2. "Christopher and Elisa," in which a father and mother discuss chapters from "Leonard and Gertrude" before their son Fritz.

3. "The Good Jacob, how he teaches his Son," an article in the Schweizerblatt, a journal in which was discussed everything, great or small, which was good for domestic use.

4. "How Gertrude teaches her Children," an attempt to give mothers a guide so that they may teach their children themselves.

5. "The Natural Schoolmaster," or a practical guide for the elementary instruction of children in all preliminary knowledge up to their sixth year.

6. "A Book for Mothers," or a guide for mothers, enabling them to teach their children to observe and to talk.

7. The address of Pestalozzi to the British public, soliciting them to aid, by subscription, his plan of preparing schoolmasters and schoolmistresses for the people, that mankind may in time receive the first principles of intellectual instruction from their mothers (1818).

8. Pestalozzi's very last speech, made a few months before his death, bore this title, "The Simplest Methods whereby to educate a Child at Home from the Cradle to its Sixth Year." 
9. But, above all, should be mentioned his "My First Book for the People, Leonard and Gertrude," which, if it is anything, is an encomium of the home.

Gertrude is his ideal teacher. She is, he says, the woman who makes her house a temple of the living God, and wins heaven for her husband and her children. Pestalozzi is always ready to pay a tribute to the mothers, his own genius being distinctly feminine. There was in him, says Niederer, as much woman as man.

"The mother," says Pestalozzi, "is qualified by the Creator himself to become the principal agent in the development of her child."

The revolutionary ideas on home education which Pestalozzi cherished are still further expressed in the following quotations from his speeches and writings:

"And thus the central and essential principle of education is not teaching, but love, which alone is an eternal emanation of the divinity within us."

"The only sure foundation upon which we must build for institutions for popular education, national culture, and the education of the poor is the parental heart, which, by means of the innocence, truth, power, and purity of its love, kindles in the child the belief in love." (Address at his seventy-third birthday.)

"The parent's teaching is the kernel of wisdom, and the schoolmaster's business is only to make a husk over it."

"Forget, mothers, if it is necessary, all other work, all other attachment, in order to penetrate into the purity and the sacredness of your maternal vocation."

"Good mothers, let it not be unjustly said any longer that you have not understanding and strength for what in your circumstances is your highest and holiest duty. If you once go so far as to weep in the stillness of your chambers 
because the good Gertrude did more for her children than you have hitherto done for yours, I am sure that you will then try whether it be not possible to do what she did, and it is when you are arrived at this point that I wish to offer you my elementary books."

"Mothers, show at last, after these centuries, the injustice that mankind has done you in seizing from your hands the first instruction of your children."

The last is very characteristic. The staple notion that Froebel continued and supplemented the work of Pestalozzi is somewhat misleading. Though Froebel can be quoted to show that he believed primarily in home education, in so far as the kindergarten takes the children away from their mothers it is the very abrogation of Pestalozzi's ideal.

A father visiting the Burgdorf institute made this remark, "Why, these exercises are so simple that my wife and I could give them at home." "The very thing you ought to dlo," was Pestalozzi's quick reply. In another instance a visitor remarked, "Why, this is not a school, but a family." "That is the greatest praise you can give me," said Pestalozzi.

In a discourse delivered on the occasion of his seventysecond birthday he proposes to use the money he hopes to get from the republication of his works to continue experiments in pursuit of ever simpler means for elementary teaching in the home. Elsewhere he says: "For a half century I have been seeking with unwearying activity to simplify the elementary instruction of the people. I desired nothing else, but merely sought to render the ordinary means of instruction so simple as to permit of their being employed in every family." This is why he was so determined to simplify, to mechanize, to psychologize education. He used to say that his method of Anschauung (sense 
perception) was not the end to which he devoted his life, but simply one of the special means by which he hoped to reach it.

From Stanz he writes, "My aim was so to simplify the means of instruction that it should be quite possible for even the most ordinary person to teach his children himself ; thus schools would gradually almost cease to be necessary so far as the first elements are concerned."

Very interesting is a passage from a letter in which he contrasts himself with the German Rochow: "I wish to elevate the people without special establishments, through the fathers and mothers whom I seek to enlighten, and he wishes to influence them through the schools. Both means are good, but the first is the only possible one for me."

Yes, he goes so far" as to say, "the schools can never become a substitute for domestic education. Only as adjuncts and stop-gaps can they hope to serve the world." In his utopian dreams Pestalozzi undoubtedly pictured a society in which all primary-school education was carried on in the homes.

We have dwelt at length on Pestalozzi's idea of the home because we must single out that one idea and make it central if we are to have an adequate appreciation of Pestalozzi's purpose and of his message. The home is the center toward which all his thoughts on education converged. Gertrude is the generic mother, the Wohnstube the generic home on which the regeneration of society depends. Be it never forgotten that Pestalozzi's aim was the regeneration of society. He was something more than an educationist. Strong as was the teaching impulse in him, the social-reform instinct was more fundamental. Liebes Volk, ich will dir aufhelfen! It was that instinct which turned him from all palliatives to the home. Vaterhaus, du Schule der Sitten und des Staates! 
Misawa has neatly stated the difference between Pestalozzi and Rousseau in the following words: "Not go back to nature, but go back to the home. Not to build a new society on the absolutely free, independent, natural man, but on the work-loving, man-loving, God-loving, unsophistically developed social man, or rather home man."

Pestalozzi's pedagogy is deeply social. He became an educational reformer only because he was a social reformer. Natorp, one of the leading exponents of social pedagogy in Germany, says, "It is Pestalozzi's distinction to have put back the question of education on a social basis, and the social question back on the basis of human education." Ziegler says, "The true greatness of Pestalozzi lies in the social spirit of his pedagogy, in the realization of the close relation of the social problem with the problem of true human development, in the idea of rescuing fallen humanity from destruction through the awakening and strengthening of its best human powers, helping it through education to self-help."

After all, is Pestalozzi anything more than a fascinating historical character, a fortunate fanatic? Have time and change canceled his teachings, or do they possess a present worth? Is there any reason for the cry, Back to Pestalozzi? He has been compared to the great 'Teacher, Christ himself, so it will not be sacrilegious to put the question this way: What if Pestalozzi came to Chicago?

Chicago is the greatest railroad center in the world, and is all that this implies; Pestalozzi was two years in his grave before the first railroad was finished. Chicago is the greatest meat center in the world; Pestalozzi knew only shepherd's crooks and little flocks. Chicago is a city of factories and tenement houses; "Leonard and Gertrude" suggests a spinning wheel and a peasant's cottage with vines 
growing over the door. "Agriculture was the reigning task of the eighteenth century." Two thirds of Pestalozzi's life fell in that century; he had witnessed and participated in the agrarian French revolution; but what did he know of that great industrial revolution wrought by steam and electricity, - a revolution which has had vastly more to do with determining the structure of present-day society and has added such baffling complexities to the social problem? Pestalozzi proposed to solve the social problem, so we are putting a fair question when we ask, What did he know of the industrial revolution?

We do not have all the data for the complete answer to this question, but have gathered some material from his two latest writings on social and industrial conditions. From these discussions, which were written when he was an octogenarian, it appears that he did have some vague apprehension of what was going on, but no clear grasp of the tendencies and no prophecy of what was to be. He confesses that things are not as they were in the good old days when the very rich and the very poor were few, and when substantial economic equality reigned. Each man then had his trade and his plot of land and his cottage; the more industrious he was, the more he earned. But of late Pestalozzi sees the good old domestic virtues decaying, finds less simplicity and more selfishness. He regrets that the introduction of industrial life should cause such inequalities in the distribution of wealth, should weaken the middle class and increase the number of the propertyless.

But he had no conception of the great modern proletariat. His ideas remained rather old-fashioned, Poor-Richard-like. $\mathrm{He}$ is not very radical on questions of legislation; he upholds monarchy and believes in a benevolent aristocracy. He thinks that most of the inequalities in wealth are 
inevitable. The child of the poor man must be educated to poverty, he says; the rich man must be taught charity and unselfishness. If the good housewife keeps the kitchen clean and takes good care of the children, if the father will be faithful at his trade and not frequent the tavern, if the pastor will not be too theoretical, and the magistrate honest and kind, all will be well. Material improvements, while important, are not primary; human nature must be inwardly elevated. "So much I early saw, that the surroundings make the man; but just as early, that the man makes the surroundings." And so to the end he retained his sublime faith in education. He did not realize the desperate power and the relentless tendencies of the changing industrial environment. He sees in the new commercial spirit - the evil Zeitgeist, as he calls it - only a passing thing which will disappear when Switzerland goes back to the good old domesticity of the good old days.

With his limited knowledge and experience it was almost impossible that Pestalozzi should understand the industrial revolution, even though the English manufacturer, Robert Oren, on his visit to Yverdon, may have told him something of the state of affairs in England, where the revolution was writing out its meaning in tragic characters. Ten years before Pestalozzi died, mobs of starving English workmen had smashed, in riot, the newly invented power machines, and paraded through the streets with a banner that displayed this inscription :

\section{Present State of Great Britain}

Four million people on the point of starvation

Four million with a bare subsistence

One and a half million in straitened circumstances

A half in dazzling luxury

Our brothers in Ireland in a state worse 
Evidently the Pestalozzian problem of poverty was not local to Switzerland. Do not forget that as early as $\mathbf{1 7 9 8}$ Joseph Lancaster, the English Quaker, had opened a free school for the instruction of poor children, and that Robert Owen, who had a spirit of philanthropy no less admirable than that of Pestalozzi himself, had already established the first infant school in England. Robert Owen, the millionaire manufacturer, "the father of English socialism," was a direct product of the industrial revolution, and he realized it. "Perish the cotton trade!" he exclaimed, "perish the political superiority of our country, rather than that they shall be upheld by the sacrifice of everything valuable in life!" He too concerned himself with the problem of poverty, but regeneration by education was not the sole factor in his remedy. His ideal included a reconstruction of the enviromment. Just as Pestalozzi, the social reformer, was turning eighty, Robert Owen, the socialist, appeared before the United States Senate and stirred the life of the nation by his appeal for governmental support to his grand communist scheme, his prairie farm of thirty thousand acres which he was about to organize in New Harmony, Indiana. One year before Pestalozzi died, our Albert Gallatin said, "The New Harmony system of education is the best in the world." It claimed to be based on Pestalozzian principles. Robert Owen was its founder; William McClure, who had met Pestalozzi in Paris, was one of its teachers; the other teacher was Joseph Neef, of Switzerland, the author of the first American book on pedagogy, and the former colleague of Pestalozzi.

New Harmony, Indiana, is not very far from Chicago, so, after all, we have got back to our starting point. Has the present industrial age, typified in Chicago, put a veto on Pestalozzi's fundamental conceptions about home 
education? Could he solve the social problem without knowing the social problem? Ziegler says, "A social pedagogy! Pestalozzi created such at a time when there was not even a social problem, or, better, when this had not risen above the threshold of the consciousness of mankind. We are only now beginning to understand the boldness of his pedagogical creation." Ziegler implies that the program in "Leonard and Gertrude" can be applied to Chicago. Whether we agree with him or not, the Pestalozzian problem of poverty still exists. The poor are yet with us. We have ten million of them in our country this very day. Back to Pestalozzi? Whether or not we go back to all the principles of Pestalozzi, one thing is certain : if the educators of to-day are, like him, to have a real share in the solution of the social problem, they must be actuated by his spirit of social conservation, and believe that "there is no greater crime against God, man, and fatherland, than to stifle the seeds of good in the poor." 


\section{CHAPTER XXIII}

\section{A HEALTHY BODY}

Common sense and Herbert Spencer both say that the first requisite is to be a good animal. 'This is, if anything, more true of the child than of the adult, for in childhood the animal body, which is destined to be the physiological house and instrument of the adult mind, is growing, and the growth should be sound, lusty, full. In childhood, health has a double value; it furthers the fulfillment of child life and promises a complete maturity. In still another sense does health always have a double value. Our lives are in the flesh, our spirits embodied, and therefore health beantifies and perfects not only the body but also the soul. The hygiene of to-day must recognize as together what God has united.

Health and education are almost identical conceptions. Society and the school cannot do their full duty until they take into account the whole child, body as well as mind, and that in a spirit of hygienic solicitude. The following survey is necessarily very limited, but it aims to be concrete enough to give to the primary-school teacher an eye and a feeling for the most palpable phases of physical health.

The teeth. One of the most important events in the physical development of the little first-grader is the eruption of the sixth-year molar. So far from being a conspicuous, dramatic event, it usually excites no notice. We look into the mouths of horses, but how many parents and teachers ever concern themselves about the child's first permanent molar? It does not take a specialist to know the simple, fundamental 
facts about the hygiene of the teeth, and yet ignorance is the main excuse for our neglect. In fact, the sixth-year molar, appearing before the milk teeth are shed, is often ignorantly extracted as a useless temporary tooth.

And it is the most important tooth in the head! If every tooth is a diamond, as an oriental proverb holds, then this one is the most precious of all. For a half

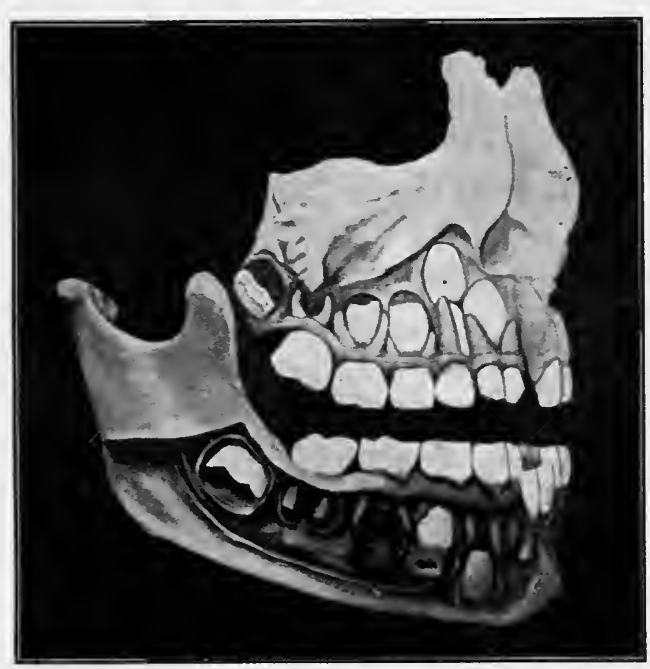

(C) Sanitol Educational Association, St. Louis, Mo.

Fig. 53. The First Permanest Teeth (For explanation see text) dozen reasons it should be most carefully protected: first, it is the first permanent tooth to appear (its biting surface, or cusp, being formed at birth); second, it is the largest, strongest tooth, and the one most essential to mastication ; third, it is the easiest to decay; fourth, it is the keystone of the dental arch; fifth, its location determines the alignment and occlusion of the succeeding teeth; sixth, its misposition may even affect the shape of the jaw.

Every teacher should therefore be able to locate the sixth-year molar in any child's mouth. This is simple. One has but to count from the middle, beginning with a central incisor; the sixth tooth in order should be the sixth-year molar. The accompanying figure makes this clearer. It 
shows the condition and position of the teeth at the age of five and a half. The child has lost the two first incisor teeth and is receiving the incisor teeth of the second set; also, the sixth-year molar, which is the first permanent tooth, is being received back of all the first teeth, and it is very nearly in position. At this time the crowns of the cuspid and bicuspid teeth of the second set are being formed, and absorption is starting in the roots of the first teeth. The crown of the twelfth-year molar, which is the second molar of the second set, is here shown starting to form. The figure pictures how the jaw enlarges to receive these teeth.

Another proverb might be cited to justify the insistence on the value of a little detail like the sixth-year molar: "For want of a nail the shoe was lost; for want of," etc. Better still, we can quote an actual case of moral delinquency, described by Dr. A. H. Holmes, directly traceable to a misplaced sixth-year molar.

The boy in question went from bad to worse, and finally reached the juvenile court. Fortunately he was sent to a dental clinic, where the following diagnosis was reported: "On the lower right side the space between the first permanent molar and first premolar has been partially closed by the pushing forward of the first permanent (sixth-year) molar. This condition has led to a partial impaction of the second premolar, which is as yet unerupted and which may be a source of peripheral irritation. On the whole, the case is, from my point of view, a typical one of what I call dentitional stress, that is to say, of nervous irritation, which frequently arises cluring the period of exchange of the permanent for the deciduous teeth."

The nervous irritation in this instance profoundly disturbed the very morality of the boy, and on its removal 
"his whole nervous system seemed to express itself in one sigh of relief." 'The transformation of the boy's behavior was almost instantaneous.

While such acute cases may be somewhat exceptional, defective teeth are almost universal. Statistics show that from 80 per cent to 100 per cent of school children have diseased teeth, and the proportion is greatest in the primary grades. One investigator found that "of three thousand Americans over twenty-five years of age only seven had all four sixth-year molars in the mouth."

Dr. George Cunningham, director of the free dental institute (without forceps) for school children at Cambridge, England, found that only 2 per cent of the children in vestigated had sound teeth. In round numbers one thousand out of three thousand children "had free pus in their" mouths, some of which would be swallowed every time food was taken, while other portions of it, thrown out in speaking or singing, would go towards polluting the school atmosphere and lowering the vitality of both children and teachers." The unclean mouths of children are therefore responsible for some of the odor and the very pollution of schoolroom air.

Some day, when preventive hygiene and the physical care of children have been more fully realized, posterity will be appalled by the conditions which now prevail. Though a rough dental examination is included in medical inspec. tion, school dental clinics and children's dentists are almost unknown. The profession is still consumed with the lucrative repairing of adult mouths and the annual installation of millions of manufactured teeth.

The orthodontists are something of an exception. 'They take advantage of the fact that the jaws grow and form about the roots of the teeth, and that the teeth-determine 
the size and shape of the jaw. They are doing an admirable work in aiding plastic nature to produce more shapely jaws. Teachers should know what marvels can be wrought by orthodontia for children with protruding, spaced, or irregular teetl, and with underdeveloped or misshapen jaws and chins.

But infinitely more essential than orthodontia, bridge work, or any other clever repair is simple, religious cleanliness. The importance of consistently caring for the temporary teeth from the time they are cut until they are outgrown is not yet appreciated. These are the reasons why they should be protected with great care: to insure good, comfortable mastication ; to establish early the cleanmouth habit; to prevent pain, nervous irritability, and ear troubles, that go with decay; to avoid a poisonous bacterial condition of the mouth; to insure the healthy, regular eruption and development of the permanent teeth, and especially the first molars. Simply because the child's first teeth are to be ontgrown, they cannot be neglected with impunity. As Dr. Burnham has said, "It is a concrete case in the child's anatomy where normal immaturity is a condition of normal maturity."

Some day society will realize that the well-developed child is the most valuable possession of the race, and in the light of that realization may provide for the periodical, thorough cleansing, by mechanical appliance, of the teeth of school children. School nurses could easily be trained to perform this important prophylactic service.

Some one has summed it up in this way: "Without good teeth there can be no thorough mastication ; without thorough mastication there cannot be perfect digestion; without perfect digestion there cannot be nutrition; without nutrition there cannot be health; without health, what is life?" 
The nose. Though not always ornamental, the nose is very important for physical health, for the good reason that the nostrils are lined with a delicate mucous membrane which filters, warms, and moistens the air which passes over it. Anything which interferes with this function of the nose as a "practical hygienist" must be fatal to health and growth.

This is why adenoids are so serious; and at least 5 per cent of our school children suffer from adenoids, which may be removed by a simple operation. 'The best time for such operation is, in most cases, before the age of six, which means that primary-school teachers may have an opportunity to do an invaluable service in detecting this defect and urging its timely removal.

Just behind the rear openings of the nostrils, and between and above the Eustachian tubes, lies the pharyńgeal tonsil. Normally this tonsil is at least harmless, and naturally is absorbed by about the sixteenth year, but in about one child out of twenty it becomes overgrown, usually before the age of six, and, because of its strategic position, does extremely serious mischief. In the first place, it blocks the natural passage of air; this is equivalent to putting a damper on the furnace of life. Mouth breathing and, at night, labored snoring result. The child's vigor is sapped, and physical growth is retarded. The Eustachian tubes may become clogged, infected, and inflamed, producing earache or partial deafness. The habitual open month and the disuse of the nostrils favor the buckling of the roof palate into a high vault. 'Thus the upper dental arch becomes too narrow for the teeth, which are crowded; the upper lip is sympathetically shortened; the nose loses its chiseled character and may broaden at the bridge. But parents and teachers are often strangely blind even to these pronounced 
physiognomic symptoms. Other frequent physical effects are diminished stature, decreased circulation, defective speech, flat and feeble chest (with increased liability to tuberculosis), and stoop shoulders. There are also characteristic mental symptoms affecting memory, attention, and disposition, which will be referred to later.

The following sentences by Dr. Burnham summarize the main practical points: "Upon a conservative estimate there are in the kindergarten and elementary grades in this country from one hundred thousand to two hundred thousand children suffering from adenoids. Immediate detection and treatment by a competent expert are likely to mean the prevention of much discomfort, increased efficiency in school work, and the opportunity for normal development. . . . Here is a case where no devices of formal education can atone for hygienic neglect."

The ears. About the ears there is less to be said. Earstrain, however, may be as injurious to health as eyestrain, and defective hearing even more prejudicial to the pupil's mentality, his speech, and his conduct. Although a simple test with the watch or with whispering is sufficient to discover most cases of deficient hearing, they often go unnoticed, and sometimes with great injustice to the child. It is estimated that from 5 per cent to 25 per cent of pupils in different schools are below normal in hearing.

The fact that impaired hearing often accompanies adenoids is significant. The great majority of cases arise from a catarrhal condition of the middle ear. Sometimes the trouble is simple lack of cleanliness, and may be remedied by the use of soap and water, warm oil, or a solution of soda.

Chronic discharge of the ear is a serious affair, and should stir parents and teachers to seek medical advice. The source of the discharge may be scarlet fever or 
measles, or a catarrhal or obstructed condition of the nose and throat (adenoids and enlarged tonsils). Usually the infection spreads along the Eustachian tube (the channel between the ear and the pharynx) to the middle ear, producing inflammation and an abscess, the pus bursting through the eardrum. In fatal cases the infection spreads by way of the mastoid bone to the brain and its coverings. Apparent stupidity, inattention, and disobedience may result from partial deafness. Discharge of the ear is serious.

The eyes. If the primary-school curriculum is very bookish and wordy, the visual mechanism comes in for a severe and unnatural strain, and the eye may not attain its full size and strength. "The eye was developed for general-purpose vision," says Dr. Terman, in an article on "Education against Nature." "It is only in the last few centuries, since printing and literary instruction have become universal, that the eye has been generally robbed of its freedom, - domesticated, so to speak, — and harnessed into the wearying treadmill of the educational machine." The teacher must be on the lookout for both hereditary and acquired defects of vision, which are the result of these civilization conditions. If she were among primitive peoples, she would not have to be so alert.

The chief varieties of eye defect are myopia (near sight) and hyperopia (far sight), causing respectively a focusing of the image behind and in front of the retina; strabismus (squint), due to a deviation of the eyeballs; and astigmatism, due to imperfections of the cornea, or lens, causing a blurred image.

The list of symptoms associated with eye troubles is rather long, and includes inflammation, watering, congested lids, crusts, twitching, dizziness, blinking, scowling, frequent headaches (especially in the frontal regions), lack 
of application, cocking the head or holding a book close to the face, blurring print, and, according to Gould, many cases of lateral spinal curvature. 'To this list might be added a considerable number of "reflex neuroses," like vertigo, insomnia, indigestion with palpitation of the heart, nausea and even convulsions and nervousness, bordering on melancholia and hysteria.

Dr. E. J. Swift has shown, in an excellent discussion in his book "Mind in the Making," that one of the most frequent sources of such neuroses is the eyes. He adds, "Teachers should know the part that reflex neuroses play in mental lygiene, and in their preparatory training they should learn to recognize the indications of these affections in order that the nervous irritation may be relieved before it becomes a serious menace to brain growth and mental development."

Posture. Malposture means cramped lungs, heart, and intestines, and sometimes even a sympathetic loss of symmetry in the two halves of the face. The abdominal muscles relax, and that means a weakened support for the viscera. The spinal muscles weaken, and that means a diminished circulation in these museles and in the spinal cord, where are located nerve centers vital to the organs and, indirectly, to the whole bodily and mental tone.

It would be wrong to regard malposture as a specific, intrinsic defect. It is often a symptom. Developed abdominal muscles, exercise, and rest invite correct posture, and malposture may be but the betrayal of their absence.

Nothing is quite so fundamental as posture; the erect posture is the distinction of the human being and should be proudly maintained. Says Dr. J. E. Goldthwait, "There call be no greater service to mankind at the present time than to make it possible for our children, as they develop, 
to use their bodies in such a way that there will be a minimum of waste and the greatest amount of reserve energy available for whatever use, whether physical, mental, or spiritual, to which the individual may be subjected later on in life."

Correct postural habits favor such conservation and economy of energy. Physical poise is the foundation of mental

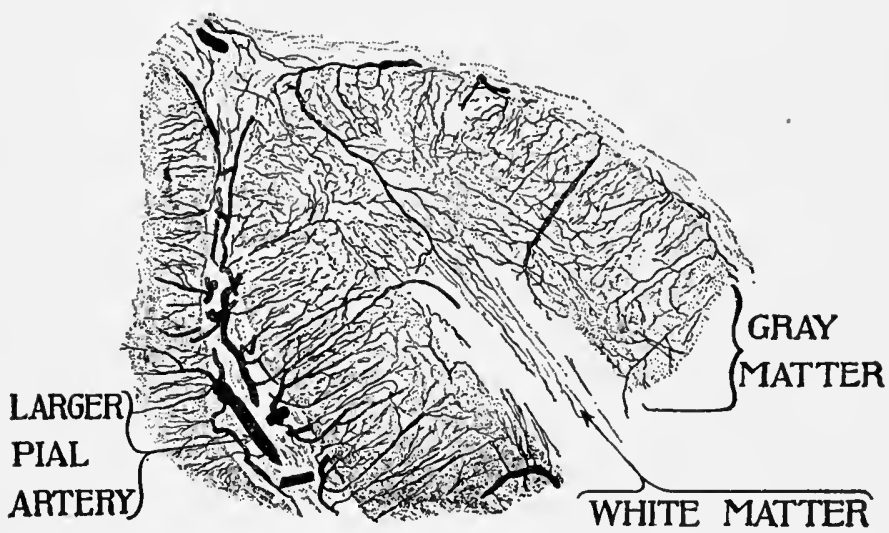

Fig. 54. Cross Section of a Convolution of the Cerebral Cortex (Gray Matter)

Showing the extremely abundant supply of capillaries. Through these capillaries the blood is bronght to the brain cells. (From Piersol's "Human Anatomy")

poise. In fact, every physical disorder is bound directly or indirectly to affect the nervous system, which is so intimately in touch with every bodily structure and function.

The brain neurons. In Chapter IV we dealt with the significance of the neuron. Considered from the broadest biological standpoint, no class of cells is more important than the nerve cells. They are the master cells which control the activity and coöperation of the subordinate cells. Considered from the narrower standpoint of education and 
personal hygiene, no cells are more important than the neurons. Their health directly affects the mind as well as the body, the morals as well as the physique. Luther Burbank, whose studies of the vegetable kingdom have given him deep insight into the needs of the human plant, tells us to " regard as the most priceless possession of the growing thild his nervous system."

Whatever metaphysics may say about the ultimate connection of the psychical and the physical, this much is certain : the neurons are the organs and instrument of our conscious and subconscious life, but, notwithstanding their exalted function, they are mortal bits of protoplasm, dependent on a blood stream.

To make this broad and far-reaching truth concrete, the reader should memorize the picture on page 284, and these few facts: "The brain requires and has an enormous blood supply." "The capillaries of the brain are not only more numerous, but they are smaller in size and their walls are thinner than those of any other tissne." "The demand for blood in abundance is more urgent than elsewhere." "Improper blood will alter mind; imperfect drainage will confuse mind." (Clouston.)

In a word, healthiness of mind depends first of all upon the condition of the neurons. This is why nutrition and rest are educational problems as real as spelling and reading. It cannot be otherwise; but, like other self-evident truths, this one is not yet the practice of the race.

Adenoids dull the mind because they injure the brain neurons. The vacant, stupid expression of the adenoid face is not due to the anatomical effect on the nose and mouth so much as to the debilitating functional effect on the brain neurons. The lymph spaces of the nose communicate with those of the brain, and when these are clogged, and when, 
in addition, the respiration is interfered with, the nutrition of the brain must suffer.

Since the cortical neurons are affected, the characteristic symptoms are distractible attention (aprosexia nasalis), disturbed emotion, and weak memory. In one instance a

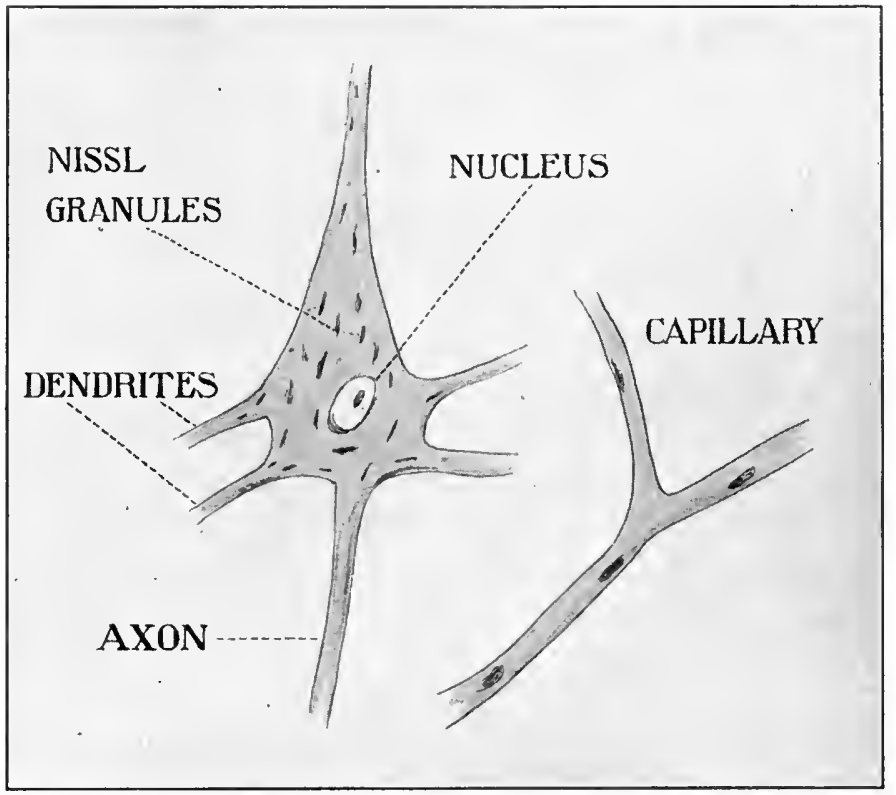

Fig. 55. One Brain Cell ani) its Blood Supply

The blood stream flows through the delicate capillary tubes and normally maintains the nutritive material which is probably stored in the Nissl grantules. (After Clouston)

primary-school child had spent a whole year in school without learning the alphabet. An operation removed the adenoids, and the alphabet was learned in a week.

In another instance a child was irritable by day, restless by night, whining, captious, and "spoiled." Adenoids, not indulgence, spoiled her, for when they were removed, her 
disposition was marvelously transformed. The brain neurons are the seat of the emotions, mood, and character as well as of memory. Healthy emotional reactions depend upon healthy neurons.

Food and air. In some large cities, like Liverpool, Lon don, and Naples, the school authorities have been almost forced to feed the school children. These school meals have had a marked effect upon mentality and conduct, for the respectable materialistic reason that a school lunch enriches the blood stream which nourishes the hundreds of millions of brain neurons in each child. But one need not go to the slums to discover the transforming effect of a timely glass of milk and a graham cracker on the attention and deportment of a primary-school pupil. Even if you have well-to-do children, the experiment may sometime be worth trying. In prosperous suburban districts you may hear the complaint that the children buy lunches of pastry and pickles. The teacher who insisted that her pupils should devote at least twenty minutes to eating lunch quietly realized that the development of the child was not confined to the recitation periods.

Air is as fundamentally important as food. No one will ever know what a tragic toll the ill ventilation of the average school has taken and is taking from the lives of millions of children. The overdry, overheated schoolroom atmosphere parches the mucous membranes of the whole respiratory system, and thus lessens their resistance to disease germs. Worse still, this air is in a state of stagnation, allowing the body of each child to "surround itself with a steam jacket," when " the entire body requires ventilation, evaporation, ' unwarming.'",

The net result of this prevailing condition is an elaborate range of symptoms, from inattention and irritability to 
dizziness and fainting, and always an insidious attack on the child's vitality. Good authorities hold that a majority of the cases of adult tubereulosis are due to infection in childhood.

The only solution is to surround all children with the "flowing, outdoor, atmospheric air." Large cities are now experimenting with open-air schools of different degrees and varieties. 'The architecture and devices are simple,tents, lean-tos, roof pavilions, sheltered porches, windbreaks, windows hung from ceilings, foot boxes, sitting-out bags, sleeping bags, etc.

Quite recently a roof school, conducted by the Chicago Tuberculosis Institute, "gathered in a group of limp, pallid, physically blighted children. They were listless, inattentive, uninterested, and uninteresting. A thirty days' régime of intelligent care and feeding, of exercise and rest, resulted in an average gain of seven pounds, and, in the opinion of the teachers, made the pupils an average group of children in alertness, and in ability to sit up and take instruction and keep up sustained interest in their work.... This was probably the one school in the city of Chicago where the boys and girls refused to take a vacation." The Eskimo suit makes the open-air school practical even in winter weather.

In another Chicago school the fresh-air experiment was tried on "normal" children. Here, too, there was a great change for the better. It did away with the necessity of much reviewing (and how much of the time in the illventilated primary school is spent in drill work!). It made one impression count, and the children became "strong, intelligent, active, cheerful, capable, and free from headaches and dullness."

Rest. The study of fatigue has grown almost to the dimensions of a special science. We can allude only to a 
few facts which relate to our central consideration, the neurons. All exertion affects the neurons in two ways: indirectly, through the diffusion of waste products in the blood; and directly, by a consumption of the nutritive granules in the cell bodies of these neurons. Sleep is the sweet restorer of the granules.

Painstaking chemical and microscopic investigations reveal these fatigue conditions, but unfortunately there is no handy X-ray device whereby the teacher can detect them. She must educate herself to look for all sorts of secondary symptoms, subtle and pronounced; heavy upper eyelid, irritability, inattention, obstinacy, restlessness, loose posture, twitching, incoördination in speech, etc.

There is another symptom of fatigue which only the expert diagnostician can discover. This is climinution in the number of red corpuscles. In one interesting count in a group of school boys and girls in Germany the average number of corpuscles per cubic millimeter of blood was increased by almost one million after a two months' vacation in the country.

Nature's inexorable rhythms cannot be opposed without penalty. The curve of activity in the amœba is a series of waves showing regular alternation of exertion and rest. Rest is as necessary as food, because physically it is the condition of chemical replenishment and growth. Rest is as necessary as attention, because psychically it is the condition of mental assimilation and growth. Mental assimilation is a subconscious process on a par with organic anabolism.

Rest, nutrition, ventilation, - these factors are first in the development of the child. The day may come when every child will be treated as incipiently tuberculous, and when he will be freely furnished with proper food and air, sunshine and sleep. What a sad joke it would be if, with 
this belated justice, half of the problems of pedagogy should suddenly evaporate!

In this day and age health and education are no longer separable. The teacher may argue that it is her business to teach, and say, "Let medical inspection and health boards do the rest." But the medical inspector is at best an infrequent and hurried visitor, and he always needs the intelligent coöperation of the teacher. When there is no medical inspection, her vigilance over the child's physical development is still more imperative.

The wide-awake, responsible teacher simply must assume the "physician's attitude" toward the child, and do what she can "to adjust school activities to his health and growth needs." She must become a diagnostician, even if an amateur one, and learn the elementary signs of retarded or defective physical development. 


\section{CHAPTER XXIV}

\section{A HEALTHY MIND}

The fundamental facts of mental hygiene are inseparable from those of physical hygiene. We have shown that the brute health, the vigor of the mind, depends first of all upon such physical considerations as eyes, ears, nose, and blood, food, air, and rest. The nicer and higher details of mental hygiene are inseparable from pedagogy, or from education in a particular sense. Given a sound body, a healthy mind is possible; but the inner organization of that mind into desirable, well-proportioned sentiments, habits, and attitudes depends after all upon the pedagogical values of the home and the school.

This fact, though rather abstractly stated, has very important bearings on all matters of school practice. It means that pedagogical methods should not be tested by their success in imparting prescribed subject matter, but by their effect on the health of the mind. In a word, it means that education should be conducted from the standpoint of psychoprophylaxis. There is no question which more directly tonches to the quick the value of any school exercise or school program than this one: Does it promote a healthy mind and healthy-mindedness?

We have tried to represent this point of view throughout the discussions in Part Three, insisting all along that the good method is not a device which most promptly imparts a bit of memory material, but is the method which preserves the right mental atmosphere, builds up the right prejudice, 
the right attitude, and encourages healthy personal reactions in the child.

The mind is a unitary living organism which, though it is bound up with a physical organism, has a distinctive hygiene. As the physiologist has distinguished the various bodily functions of assimilation, excretion, ete., so the psychologist has discriminated the functions of the mind. They have been happily characterized by Royce as the unlearned reactions, docility and initiative. 'The first function comprises all the instincts and native tendencies; the second, all the culture traits, habits of perception and action, the acquired tendencies of behavior. By "initiative" is meant the original, free, creative aspect of mind. It, more than anything else, stands for what is distinctive in the individual, for his genius.

Now children, as well as adults, have these three phases of mind, and it may be said that mental health depends upon the preservation of all these phases in their full power and harmonious proportion. 'This statement sounds rather' theoretical, but it has a thousand concrete applications in school management.

If heredity were all, then mental hygiene would not be so necessary. The mind qualities and tendencies would, from an inborn power, come to maturity. Heredity places certain marks and limitations on mentality, but it does not absolutely insure the development of its possibilities. A child may be a natural-born imbecile-you cannot make him normal; but if neglected or unwisely treated, he is quite likely to sink to the plane of an idiot. Undoubtedly, normal children are often made pseudo-feeble-minded by unwise school methods.

One of the chief symptoms of feebleness of mind is a lack of the qualities of initiative, independence, resourcefulness; 
and these are the very qualities which the schools do the least to preserve. It is absolutely certain that poor teaching can bring about a cerebral enfeeblement which will destroy some of the finest elements of child life, - eagerness, spontaneity, originality, curiosity, - the qualities of initiative. In the chapter on instinct we showed the hygienic significance of relaxation. The highest function of relaxation is to nourish the natural sources of these supreme qualities of personality. The conservation of these same qualities should be the highest aim of educational hygiene. More of this in the concluding chapters. The relationship of the sense of humor to a healthy mind is so important that we have devoted a special chapter to that subject.

The mind is a living unit, but a unit with three expressions: thinking, feeling, and doing, - intellect, emotion, and will. Hygiene recognizes the natural unity of the mind, and insists that mental health depends on a proper coördination of all three expressions. Pedagogy also must recognize this natural unity and beware of any practice which artificially dissociates thinking or doing from feeling. It surely is true in the adult that unhappiness, not to say mental abnormality (subjectivity, melancholia, etc.), results if emotion is ineffectual or if there is a great gap between thought and action. The mind must be firmly knit together to be healthy.

The mental hygiene of the child at the primary-school age is doubly important because it affects health of mind in youth and in maturity. Childhood is, from the standpoint of hygiene, the foundation of youth.

Dementia procox is a pathetic youthful failure of mind, an adolescent mental deterioration which supplies almost one third of all the admissions to hospitals for the insane. The central feature of this dementia is a dissociation of 
thought, action, and feeling. The subject often sinks into a state of stuporous inactivity, with empty ambitions and reduced emotions. It is coming to be believed that this peculiar mental dilapidation and irresponsiveness is not necessarily due to organic, morbid heredity, but may be the lawful outcome of previous faulty adjustments to environment, of poor education, and serious lack of "concrete productivity." By fostering hearty attack of tangible problems, absorption in concrete interests, and healthy habits of work, the primary school may perform a preventive office in diminishing the liability to dementia procox and milder approaches to that condition. The school must not be needlessly guilty of dissociating thought, feeling, and action.

The mistake of many school methods is that they do not treat the child as a unit. They seem to regard him from a phrenological standpoint, as though his brain were a bundle of independent organs, one for writing, another for number, etc. Nature intended the child to work as a unit. Intellect, feeling, and will should function together, reënforcing one another.

In this trinity, feeling is both central and fundamental. Feeling, mood, emotion, desire, attitudes (they are all kin), are born of instinct, and there is nothing more fundamental in human nature than instinct.

Nature desires children to work by mood and motive. This, we think, is the supreme principle of mental hygiene applicable to the problems of child life and primary-school education. It is unnecessary to add that by mood we do not mean a passing whim, but a feeling atmosphere which initiates, supports, and energizes what the child is doing.

For the hygiene of instruction this principle is very farreaching. The following will recall the application of the principle to the program and pedagogy of the primary school: 
Drawing needs the artistic mood, the desire to express. So does the dramatic work. Both should be a "natural reaction to feeling."

They are like language. Language cannot be taught; it must be evoked. It must spring from a wish to say something.

Phonics instruction must recognize the factor of feeling, the spirit of play. It is bound to fail if it is formal, technical, listless. Melodious speech depends primarily on mood.

Reading should have a motive. It should be accompanied by the feeling of creativity, of investigation, - the desire for information.

Literature, above all else, must be pervaded by and awaken fitting moods.

Even nature study must not be solely informational. More important than mere facts are the feelings for the facts, the attitudes toward nature, life, sex, etc.

Handwriting, which is the most purely technical subject in the whole curriculum, suffers if feeling is absent. It prospers best with the support of the rhythmic mood.

The morning exercises, however brief, may become the most precious part of the day, because they are psychological moments for setting moods and awakening varied emotional attitudes of joy, seriousness, and humor.

Busy-work is a foe to child life if it invites disintegrating languor. It should nourish the spirit of achievement and pride in efficient effort.

Discipline reduces itself to the maintenance of the right working attitudes in the classroom.

Finally, in handwork the chief consideration again is attitude, - attitude toward work. Here intelligence, feeling, and will must join to bring about joyous, purposeful 
activity. Love of independent effort, joy of attack, enthusiastic persistence in work, - these are the vital things to preserve. The reason why handwork, all in all, furnishes the best medium for the education of the primary-school ehild is because, more than any other subject, it enlists this whole personality energized by mood and motive.

Primary-school children, even more than older children, need to preserve the integrity of personality. They are more generic, less differentiated, less open to speeialization ; and premature specialization, which invites only part of their energy, injures the health of their growing minds. 'They throw their whole being into play. Nothing so unifies their whole nature as the spirit of play, and the work of the school ought to enjoy the same mifying mood and motive. Short periods of intense, whole-souled activity-followed by relaxation, - this is the ideal of primary-school education.

The time is sure to come when the school will more frankly and fully carry out this ideal by interspersing the school session with periods of complete relaxation. Chronie busyness is the bane of school life, even though the etymological meaning of the word "school" is "leisure." Steamer chairs and reclining cots have a place in the development of normal as well as of sickly school children. The valuable art of taking a cat nap or a recuperative "let-down" might well be tanght in the kindergarten and primary grades; that is, if we really believe that one of the aims of education is the development of healthful habits of relaxation.

When we attempt to describe the qualities of a healthy mind, we naturally use those adjectives which also apply to the healthy body, such as " strong," "vigorous," "prompt," "balance," "effectual," "organized," and "athletic." An athletic body is one which will take hurdles nicely, which 
will expend just the right energy in taking them. So also is the athletic mind.

These athletic qualities have their beginning in the primary school, and are nurtured in the daily habits of study, the habits of play and work. Habits of dawdling activity and moodless lassitude make the mind which is as inert and inconsequent as an atrophied muscle. Surely this is not the healthy mind; it is the enfeebled mind, for which education, rather than morbid heredity, is responsible. The healthy mind is the mind which, though organized by wholesome habits, keeps on growing in the power to achieve and to enjoy.

The whole child comes to school. Health alone can keep him whole in body and in mind. To guard this lifeenriching health, the teacher's love must be pervaded with the physician's attitude, for surely she is called to be a physician to the growing mind. 


\section{CHAPTER XXV}

\section{THE SAVING SENSE OF HUMOR}

The whole country is alive to our industrial waste, and necessity has made conservation a national ideal. Water, wood, oil, and coal must be used advisedly, that future generations may not pay the penalty of our improvidence. It is realized that these forees are motive power, that they hold the initial energy which drives the great industries of the world. Their use or misuse is a matter of public concern. A machine that uses-energy out of proportion to the power it generates rusts on the market.

But what of human energy, particularly that of the child? The schools are great machines that are eating up the energy of childhood and keeping no record of the waste.

The eonservation of life is an ancient and noble ideal. We all desire that our lives should be fulfilled, not thwarted, that they should be abundant, not scanty. And this should be the ideal of the teacher and of the state in their relation to the lives embodied in eager, joyous children.

But this is just the ideal most difficult to carry out. On every hand are "the masters of life" - convention, tradition, economy, habit - conspiring to imprison the living energies of teacher and pupil within rigid confines. What can we do to stave off these foes of the best, the variant, the distinctive elements in the individual life? Cultivate the sense of humor.

It is the function of humor, as Kline has so well said, "to increase the pliancy of mental structure, to check 
mechanization, and to preserve and fan sparks of genius." "Humor keeps the individual young, projects the best in youth into adult life, sets metes and bounds to docility, and prevents the mental life of the race from hardening into instinctive and hereditary forces." Dr. Stephen Colvin in a recent article has called timely attention to the neglected educational value of humor. "To educate in humor," he thinks, "is to furnish a liberal training, to humanize. Training in humor would do much to equip the individual with mind to meet the caprices of fortune with fortitude, intelligence, humanity, and, if need be, with resignation."

Gorki, in one of his great novels, says: "God makes things round, such as the earth and all the stars and everything visible to the eye. The sharp angular things are the work of men." The avcrage schoolroom is a fine example of this man-marle angularity. The very building of which the room is a part is often excessively rectangular. The seating arrangement is uniformly rectangular, and squarely screwed to the floor so that it camnot ever be altered. The checkerboard program on the board and the stiff clock stuck on the wall complete the picture. In satire the schoolmaster himself is an angular personage.

A recent anonymous writer in Scribner's has sketched a type portrait of the pedagogue, which brings out strikingly some of his formalistic failings. The portrait, though not flattering, is drawn without malice, in a spirit of psychological analysis, and "dedicated to the belief that it is now and then well to see ourselves as others see us." "When the psychology of occupations is written," says the writer, "its most interesting chapter will be one which analyzes the backstrokes of the various pursuits upon the workers." The occupational backstrokes which stamp the teacher are, briefly, a fictitious type of bearing (so different from the 
frank and easy manner of the physician and business man), a devotion to method and petty devices, a didactic habit, and pedantry. "And finally, in order to make the confession complete, it must be acknowledged that we are peculiarly liable to fall prisoners to conventionality."

This characterization is, of course, not intended to do justice to the many open-minded, sprightly members who adorn the profession, but it is one more justification for the plea that the primary schools introduce more plasticity, more humor, into their régime. It may also justify a serious consideration of the subject of this chapter.

Do the pupils themselves, when they can exercise judgment, think that their teachers are overconventional, overserious? We received a substantial answer to this question from sixty-seven normal-school students. We simply asked them to count up the number of teachers they had had up to graduation from high school (the number totaled 1679), and then to count the number of teachers they distinctly remembered as having a sense of humor or fun in the schoolroom. This number amounted to only 224, or less than 14 per cent of the total. Forty-four, or two thirds of the students, remembered either three, two, one, or no teachers answering this description. Although the students were asked to do no more than give the figures, it is interesting to know that they volunteered remarks like the following about those teachers with humor. "She was the best liked of all"; "she had the best control over us"; "I just loved her and was always glad to see her coming." One student to whom the question evidently appealed said, "I do not remember one grade teacher who could actually laugh heartily and live through it. Until I entered high school, I do not remember ever to have had a laugh worth while in connection with school work." 
Is it not high time for the schools to cherish the sense of humor instead of repressing it? Perhaps the humor sense deserves as much education as the number sense. There are all sorts of ways to educate the sense of humor in little children, but the ways and humor itself are so subtle that detailed methods are out of the question. Suggestion is the chief thing, for humor is at bottom an emotional reaction, and, like all emotional attitudes, is communicated contagiously from its source. Vivacity-lively facial expression of the humorous through the alchemy of muscle reading -will often awaken sluggish minds to like appreciation. Atmosphere, of course, is all-important, for the sense of humor will not thrive, except as a kind of instinctive reberlion, in the overserious schoolroom which does not permit the little comedies of error in the actual life of the day to be responded to.

In the chapter on drawing we have suggested the possibilities of this fine, plastic medium for the expression of humor. If drawing were developed to its possibilities, most of us might be amateur caricaturists. Should we not bring more good, funny pictures to children? Appreciation of the comic in art is no less responsive to cultivation than appreciation of the beautiful.

There is hardly an art which does not have a place for the expression of humor, - drawing, music, sculpture (clay modeling), dancing, dramatics, and literature. All of these arts are, or should be, represented in the primary school, and should, on occasion, be given a humorous turn - especially literature. Why not double up the children a little oftener with the joy of the purely funny?

The classic nonsense tale about Epaminondas and his Aunty shows that the seeds of milder philosophic humor may also be sown, or rather watered, in the primary grade. 
Epaminondas was a little negro boy who was not blessed with a high degree of "relational activity of mind." $\mathrm{He}$ brought things home to his mammy, but in stupid compliance with previous correction. The cake he crunched in his fist; the butter he carried in the hat on his head; the dog he cooled to death in the water; the loaf of bread he tied to a string and dragged home. "O Epaminondas, Epaminondas! you ain't got the sense you was born with; you never did have the sense you was born with; you never will have the sense you was born with." You are one of those numerous illustrations of the fact that too much mechanization is inimical to both individual development and racial evolution! The teacher need n't moralize, but a day or two later she may have occasion to call some stupirlly docile boy Epaminondas. The tale, as given in one of Sara Bryant's collections, goes on to tell how mammy left six mince pies she "done" make, on the doorstep to cool, with the injunction, "You hear me now, Epaminondas, you be careful how you step on them pies," and then - and then - Epaminondas was careful how he stepped on those pies. Here the story ought to end. If the story is well told, and if the children have not been mentally repressed, they will see the point without further impersonation and narration; and this is education in humor, for, intellectually, humor is a relational activity of the mind which sees the point.

There are all grades and degrees of humor. This might be expected when we remember that the smile probably had its origin in the grinning retraction of the lips which accompanied the physical enjoyment of a good feast, and that laughter was first associated with the digestion of the feast. To this day laughing and growing fat go together. In anther chapter we have already shown that, as a relief 
from constraint, laughing is an instinctive form of relaxation. It also has some primitive connections with the tickle sense, with play, and with the savage instinct of bullying. Even among the lower animals there are traces of mirth, smile, chuckle, and laugh. The sense for the humorous, in common with the other exalted powers of man, has a lineage that goes back to humble origins. An interesting passage on this point is quoted by Sully from an essay by George Eliot: "Strange as the genealogy may seem, the original parentage of that wonderful and delicious mixture of fun, philosophy, and feeling which constitutes modern humor was probably the cruel mockery of a savage at the writhings of a suffering enemy. Such is the tendency of things toward the better and more beautiful."

As in the race, so in the individual, the sense of humor is capable of development. From the clownish and sometimes savage fun of childhood to a gentle, sympathetic humor "saturated with reflection" is a long step, but not an impossible one. Even the great humorist Shakespeare had to elevate himself and his patrons from the lower levels to the higher. His early dramas, like "The Comedy of Errors" and "The Two Gentlemen of Verona," are full of buffoonery, mistaken identity, broad punning, and rustic horseplay. In his riper productions, like "Twelfth Night" and "The Tempest," the fool is philosopher and the jester exalted humorist. Can we not bring into child life more of this developing and developmental humor?

"The conservation of child life" is more than a phrase. It fully represents the deepest and most central of all problems and duties. We are not thinking of physical health only but also of psychic values. Physical health will always remain the first requisite, but life is more than circulation of healthy blood. The child will be a man, and 
what will serve him best then are the generic qualities of childhood, elasticity and eagerness of spirit. The preservation of these qualities is the conservation of child life and should be the highest ideal of education.

As school and society are now constituted we can hardly behold the buoyancy and curiosity of a child without a vague dread that these life elements are probably doomed to die out. The school does not even consciously try to conserve them. All pedagogy is mainly bent on developing the virtues of obedience, accuracy, honesty, faithfulness in memory, faithfulness in conduct, skill in technique, perseverance, and a host of proprieties. Well and good, but it is significant that these virtues are the virtues of fixity, of mechanization, even of rigidity. In Royce's terminology, they are the virtues of docility but not of initiative.

No wonder that the schools turn out such large job lots of commonplaceness. We are not earnestly trying to preserve the most precious of life elements, the variant elements of enthusiasm and originality. The dullness, the routine, the solemnity, the inflexibility of the schools, kill initiative.

If we make a rough inventory of the larger mental traits which every grown person ought to have for his own happiness and that of others, we surely must add many traits to the docility list given above. What this old world needs, in addition to the "training" of mind and morals, is a greater fund of untrained elastic spirit, flexible enough to take fresh, unbigoted attitudes toward things and problems. Let us try to enumerate some of these nondocility traits: toleration; resourcefulness in work, play, leisure; genial interest in the commonest things of life; ability to see the point; adaptability to new and suddenly shifting situations; a sense for disproportion and keenness to see through the unwarranted pretensions of others ; capacity to laugh aright 
at self and others ; control over sensitiveness. (A silly, semijealous sensitiveness is one of the most universal causes for trouble in this world, - a human trait on which a bulky sociological treatise might be written.)

These qualities, though they do not have much recognition in the textbooks of ethics and the current discussions of moral education, are of highest ethical import and value. To say that these fine qualities can be learned only in the school of life, and not in the life of the school, is pedagogical pessimism. The life of the school can be made rich and free enough to nourish them all.

There is a marked and wholesome tendency in current thought which is casting suspicion on the whole value of the first years of primary-school education. We hear it said that it would be just as well, or better, if the child did not go to school at all until he is ten years old or more. But the last word on this great subject has not been said. The child life of rich and poor alike will suffer atrophy if opportunities for expression and imitation at home are limited. It is not so much a question of home versus school as right atmosphere and healthful surroundings. Even in the primary schools it is not so much a question of upsetting the whole curriculum as revolutionizing the spirit and method of conducting the school. We have tried all along to show how the humble materials in the reach of every teacher, drawing, reading, writing, handwork, and even trivial busywork, every occupation of the school, - can be hygienically used to develop the child, to speed the growth of his free and conquering spirit. If this cannot be done, let us say that Rousseau was right, and turn the little colts out to pasture and be done with it.

But while the primary school exists it must have lifegiving breath for the spirit of its children. The thick fogs 
of formalism must pass out of the windows, and the saving sense of humor must enter. Humor is a large, life-giving trait, bound up with play, sympathy, and insight. It is related to the relaxation reflexes, which have a biological origin and a psycho-physiological protective function. It is a natural means of conserving the intellectual quality of mental pliancy and the ethical quality of elasticity of spirit. It is a saving sense, and as such has an important office in the hygiene of mind and in an educational policy of conservation. 


\section{CHAP'TER XXVI}

\section{FORMALISM AND CHILD PERSONALITY}

The overzealous parent at the door and the relentless timepiece on the wall conspire to keep an artificially precocious atmosphere in the primary school. Order, system, detail, and prescription have replaced spontaneity, grace, initiative, and investigation. The spirit of childhood languishes, and in its place stalk the stern figures of propriety and formalism. Children are variable, inconstant, and unstable; like birds on the wing they dart hither and thither, glad of the very air they breathe. They work intensively, unevenly, in short periods of effort, and flourish in freedom rather than in confinement. Mood, the unerring guide of childhood, may not be grafted on from the outside, but must spring from a joyous, inward response to a frank, healthy, childlike atmosphere.

How often the most promising child in the room is thwarted in his growth by the incessant inhibition and prescription of the early grades. The eager, questioning, imaginative child cannot endure the dull tedium of perfunctory instruction. He wants to express rather than to be always impressed. Life is new and invites exploration. $\mathrm{He}$ is not willing to memorize and visualize the symbols while the warm, living things which they represent are touching his elbow.

We have in mind a little ragged, eager boy whom the schools are robbing of his most precious gifts. He commits the sin of talking out, for his responses are quick, sudden, 
and unhesitating. He is not always orthodox in the stories he tells, for he is so imaginative that he cannot inhibit the multitude of suggestions which dance into his brain. $\mathrm{He}$ is disorderly, for he is apt to laugh, sing, or exclaim in unexpected places. He is not attentive, for his vital, sensitive nature responds to every distracting call. He lives deeply, for a host of lovely associations eling around words and things, and lead him into rambling, personal recollections. He is running over with affection, a very lover of things; he wants to handle everything, to bring life into close rapport with his own vibrating little body. He does not sit still, therefore, to wait his turn when the birls, stones, and flowers are formally passed for inspection. The stuffed bird takes on life immediately, and is like the birl who built a nest in his own yard. The dragon fly becomes the little quivering one he tonched once when he was at play. How can he repress these bursting recollections and instincts until he is asked a question?

But such a child does not fit into the school routine; he irritates by his very virtues, and is hampered by his genius. If education were more sincere, instead of ostracizing such a boy, turning him off into a solitary corner, teachers would let the contagion of his love of life permeate the whole room. They would let the purity of his kinship with nature sift into the heart of every stolid little creature in the group, and would bend every effort to grow more of his kind.

Child life and child motives are elusive, creative, elastic, and intuitive. Every growing thing in nature lives in a freer, more inspiring atmosphere than the modern child. The plants have a better chance of preserving their initial impulses and achieving their destiny. We do not make the bees rotate in order from flower to flower, nor tell the birds into which tree to fly. 
But the child is circumvented at every turn by wellmeaning adults out of harmony with his intent; even his play is crippled by formal limitations and adult conceptions of organization and courtesy. We cannot force our motives and our standards on children without arresting a natural process of growth. Why shut the children up in the prisons which we have made for ourselves out of inhibition and conventional standards?

Even if an utter revolution of program is necessary, it would be justified if we could, by such a change, preserve emotion, eagerness, and enthusiastic persistence in work. Programs are too inflexible. Periods should run over and run into one another. There are days when a protracted session, emphasizing and illuminating one idea, should wipe out all divisions into reading, writing, spelling, etc. These things are not ends in themselves, but merely the means of recording, illuminating, and impressing some idea. Children should think about the larger aspects of things and learn how to call in these technical accomplishments of reading and writing as messengers of their thought. The breathless hurry to read two pages or to spell twenty words or to write ten lines in a specified time is foreign to every impulse of childhood. It is mechanical, artificial, unreal, sophisticated, and is the refuge of tired teachers who need not then be resourceful or companionable.

Take the programs down from the doors and seize upon the psychological moments when writing, reading, and spelling really express thought and make permanent ideas upon some central topic. They should be the means of objectifying, preserving, and enforcing ideas. The child's personality cannot emerge and develop unless his emotions are stirred in vital accompaniment to his intellectual work. This is a natural law. 
The skillful teacher withdraws herself, and throws the burden of discovery and explanation upon the children. Give them a genuine problem, and then fairly turn them loose to solve and illustrate it in a variety of ways. How the children love to wrestle with problems, and how they enjoy their triumph when one is solved! Out of this wrestling and triumph personality is born.

It is time to have a reckoning, to realize before it is too late the futility of pushing nature. There are certain basic instincts implanted in childhood which wedge their way through obstacles to the accomplishment of their purpose. The little child comes running to school pushed by curiosity, energized by feeling, tingling with response to sensation, and reveling in images of past experiences, but the teacher discards these sharp-edged tools which make early workmanship easy, and substitutes dull drills.

Little children work from impulse, desire, feeling, not from prescription. The child who enters the primary school to wrestle with its problems has no standards to guide him in his intellectual efforts, save those which have preserved him physically. He instinctively seizes upon that which pleases him, for pleasure in its lighest sense has been his biological safeguard. He drinks because he is thirsty; he eats because he is hungry; and he is strengthened in a large measure by what he eats and drinks because he enjoys it. In other words, the feeling of satisfaction in the process has much to do with the benefits to be derived from that process. The recognition of this fact in physical hygiene results in prescribing laughter as a sauce to dyspeptic patients, but the part that mood and feeling and instinct play in school life and in mental hygiene is often utterly disregarded. Instead of desire, feeling, laughter, and joy of attack, the pedagogue offers duty and formalism. 
Now a child's sense of duty is a hard sense to localize. It will not be found functioning with his sense of sight, touch, smell, or taste. It is not instinctive or fundamental, like running, jumping, building, drawing. Let duty grow of itself out of love, joy, achievement, experimentation, and experience.

It is the boast of schools that everything goes like clockwork. Such formalistic uniformity and concerted action are foreign to the grace, spontaneity, and individuality of childhood. Children who grow up under such systematized direction are denied the very essence of mental growth, which depends upon original, constructive effort. The child mind loses its power to organize, and becomes as inconsequent as an atrophied muscle. Nature endowed the six-year-old child with an impulse to investigate, pry into, and discover. Some primary schools are veritable tombs of deadened curiosity and initiative.

What does the six-year-old child care for print? His fingers are itching for contact with things, and his legs are set for chasing butterflies. Too much formalism in childhood kills spontaneity and interest. Education cannot, by formulating courses of study, force intellectual functions. The laws which govern the growth of mind are as immediate and irresistible in their operation as those which govern the growth of the body. If we force either the one or the other, personality is foiled. Let us, by putting faith in instinctive impulses, conserve more of childhood to the race. 


\section{CHAPTER XXVII}

\section{CHILDHOOD THE FOUNDATION OF YOUTH}

Jane Addams has just written a book which has been heralded as a classic. In many beautiful sentences which are uncommonly pregnant with truth, because they are born of actual contact with the deepest realities of life, she defends and glorifies the spirit of youth and "its immemorial ability to reaffirm the charm of existence." In the words of one of her reviewers, "It is as if the Lady Abbess of Chicago, with gently entreating eyes, held out to us the key to those cloistered recesses in youthful hearts where nature stores the elements of human destiny." All of us who have to do with education need to learn these keys, - the primary-school teacher as well as the high-school principal who always talked about keeping quiet in the halls and never about life, - for the spirit of youth is not something altogether independent of the spirit of childhood.

In every youth the experiences of adolescence will be modified by those of boyhood and girlhood, and the richer, the deeper the child has lived, the less revolutionary and disturbing will be the experiences of youth. The best foundation for a balanced idealistic adolescence is a fullfilled childhood, and it is for this reason that the primary school has a share in perpetuating and nourishing that divine fire of youth "which is so vivid an element in life that unless it is cherished all is spoiled." Let us agree that the spirit of youth is of all things the finest in the world, but let us remember that the child is father of the 
youth. 'To save to the world the best in youth we must begin by conserving the best in childhood.

G. Stanley Hall has emphasized the differences between the periods of childhood and adolescence. We are told that the former, especially between the ages of nine and twelve, is a period of relative stability, of independence, and of mechanical interests, - the golden age of memory and habituation. It would be a mistake, however, to extend this characterization back to the primary-school age, which, instead of being marked by stability and susceptibility to drill and discipline, is naturally full of the change and spirit of adolescence. It is perhaps a nodal point in development in somewhat the same sense as adolescence, and, like it, is franght with deep potentiality. A summary of its psychological traits would reveal many interesting parallelisms between the two cpochs.

After all, the primary-school child is himself very much of a burgeoning youth, only smaller and somewhat less romantic. He too is naturally full of ardor and creative enthusiasm, " of beanty, variety, and suggestion." He too has spirit and is deciledly more than an unlettered youngster waiting with docility to learn the technique of culture, on the promise that it will be useful in later maturity. He has individuality, artistic temperament, and sense of personality. If we only understood him, he is saying, "Lo, I am here, too, and must be reckoned with." $\mathrm{He}$ is full of the joy of life and as impatient of dull routine as the spirited adolescent, though his rebellions are not as drastic and dramatic.

It is easier to say than to enact, but the truth remains that the first duty of school and state is to preserve his joy of life. Teacher's should convince the child that life is beantiful. The primary-school child comes to school with the belief 
that work is as lovely as play. See the zeal and pride with which he attacks his first intellectual problems, and the languor and discontent with which he often finishes them. Why is this? Why has the eager, buoyant first-grade child often become the so-called lazy incorrigible of the grammar grades? What has become of the pride in work, the eagerness to help, the dominating curiosity, and the warm, unselfish affection for teacher and school? Why have these deep instincts been strangled in their very birth? Why have they not been preserved to brighten and inspire the effort of his later years? Chiefly because school work loses almost immediately its intimate, human touch. It is separated from all emotional incentive and becomes thedry tedium of accumulating facts. Work is purposely made unlovely, too often associated with silence, punishment, and failure, while teachers emphasize false distinctions between it and play. Work and play, prescription and freedom, soon take sides against each other, and the child begins to show a preference; yet when he plays he works the hardest. Teachers have a puritanical habit of making work a duty and play a privilege. The gospel of the schools should be that work is lovely, that work is a privilege, that work makes use of imagination, self-expression, and joyous coöperation, and gives the individual a personal power. This will be accomplished only by changing the atmosphere of the schoolroom or workshop, by loosening the reins, humanizing the motives, and letting in some of the charm and personal contact that you meet in a studio where artists gather together to do creative work.

It is of supreme importance that we preserve healthy, eager attitudes. The child's emotional appreciation of life will be the foundation for the visions of his youth. From imitative play, friendly coöperation, and dramatic rehearsal 
of life as he sees it, he will pass into ardent longings for life as it should be. But the seeds of such victory are not sown in languor or silent inhibition, but in active, constructive daily living which awakens and makes use of the whole capacity of the child.

It is our duty to plant the seeds of victory. The fires of youth burn with a peculiar intensity. "The blooming susceptibility of sex" makes the very blood press harder and hotter in the arteries. Everywhere, but especially in the factory and the street of the industrial city, is adolescence liable to storm, uncertainty, and perversion.

Primary-school teachers should begin to change the tradition of the streets by educating the child's capacity for healthy recreation; but she cannot do this if all her time is given to reading and writing. She must make room for more self-expression along motor lines in handwork and games. She must not merely teach new words, but she must educate a taste for literature. She must, through dramatic play and social coöperation, organize the emotional life of the children. Organization of the emotions, the culture of the imagination, and the creation of compelling interests will be a safeguard against garish penny shows, and will start in their place wholesome occupations for leisure hours. We are suffering as a people to-day because we cannot spend our leisure except in excitement. 'The true and deeper things of life lie untouched by the majority of people. When resourcefulness in both work and play have been developed, the battle of youth is already half won.

Humanitarian ideals of social service are the glory and safety of youth, but we must provide hospitable soil for these ideals by fostering the social instincts of childhood. Children in the primary school are not allowed to exchange ideas, communicate interests, or give help to one another; 
we cannot afford to penalize them if they speak to a neighbor, or punish them on the ground of cheating if they show a friend how to do a piece of work. The first lessons in altruism can begin early.

Purity is another ideal which we expect of youth but do not provide for in the years before the full seed of the corn. This ideal should not be forged in the white heat of blind, heroic determination, but should be the outgrowth of years of accumulating acquaintance with nature's open secrets about plants and animals, about birth, heredity, infancy, and parenthood. A reverent contact with and wholesome insight into the elemental facts of sex may even begin with the study of nature in the primary school. In varied, subtle ways we can prepare the youth to look upon the grail of life's reality.

Childhoor is the gateway to a larger experience, and the path over which the child is led broadens into the great highway over which the youth must walk alone. Here will be enacted the drama of the soul. Here will the child, now a youth, meet spiritual triumph or sordid defeat; but if in childhood the beauty of life and its freshmess have been preserved to him, he will carry the blossoms of imagination and the fragrance of happy hours to guide the ardent feet of youth into clean, cool places. 


\section{BIBLIOGRAPHY}

This is only a brief and selected bibliography. Readers who wish to extend the list of titles will find further bibliographies in the references starred (*). Dr. Louis N. Wilson, librarian at Clark University, Worcester, Massachusetts, has published "A Bibliography of Child Study" annually since 1898 in the Pedagogical Seminary. See also "A Bibliography of the Biological Aspects of Education," by Professor Will Grant Chambers, State Normal School, Greeley, Colorado.

\section{PAR'T ONE}

Darwin, Charles. The Life and Letters of Charles Darwin, including an autobiographical chapter. D. Appleton and Company. New York.

A fascinating book with many suggestions for teachers.

Foster, Michael. Lectures on the History of Physiology during the sixteenth, seventeenth, and eighteenth centuries. Cambridge, 1901. 310 pages.

Full of rare facts. The style is interesting.

Hughes, James L. Dickens as an Educator. New York, 1901. 319 pages.

Contains many quotations from Dickens's works.

LECKr, W. E. I. History of the Rise and Inflnence of the Spirit of Rationalism in Europe. New York, 1873.

Two volumes in which will be found an animated discussion of the doctrine of child depravity.

*Locr, W. A. Biology and its Makers. Henry Holt and Company. New York, 1908. 469 pages.

A very readable, personal account of the history of biology, with portraits and other illustrations.

Proceedings of the Child Conferences for Research and Welfare. G. E. Stechert \& Co. New York, 1909.

Contains scores of short papers dealing with every phase of child-welfare activity. 
*Spargo, John. The Bitter Cry of the Children. The Macmillan Company. New York, 1906. 337 pages.

A very readable account of recent lumanitarian efforts to improve the condition of the school child, the working child, and the infants of large cities.

White, Axdrew D. A Ilistory of the Warfare of Science with Theology in Christendom. New York, 1897. Two Volumes.

\section{PART TWO}

Bölsche, Wrlhelm. The Evolution of Man. Charles II. Kerr and Company. Chicago, 1906. 160 pages.

A very simple summary, which traces the stages of evolution backward to the simplest forms.

*Bolton, Frenerick E. Principles of Education. Charles Scribner's Sons. New York, 1910. 781 pages.

A book which brings together a large quantity of material in the scientific study of education from the psychological and biological points of view.

*Borgqvist, Alvin. Crying. American Journal of Psychology, Worcester, April, 1906, Vol. XVII, pp. 149-205.

Burk, Frenerick. From Fundamental to Accessory in the Development of the Nervous System. Pedagogical Seminary, October, 1898, Vol. VI, pp. 5-64.

*Cinamberain, Alexander. The Child: A Study in the Evolution of Man. Charles Scribner's Sons. New York, 1901. 495 pages.

Contains a wealth of information on the language, play, arts, etc. of childhood, and their relation to similar expressions in primitive man.

Chamberlain, Alexander. Work and Rest, Genius and Stupidity. Popular Science Monthly, March, 1902, p. 413.

Darwin, Cnarles. Extracts from The Origin of Species, Life and Letters, 'The Descent of Man, A Naturalist's Voyage, and The Variation of Animals and Plants under Domestication, with biographical and critical essay by E. Ray Lankester. In Warner's Library of the World's Best Literature, Vol. VIII.

Gibbs And Deluinger. The Daily Life of Amoba Proteus. American Journal of Psychology, April, 1908, Vol. XIX, p. 236. 
Hall, G. Stanley. A Glance at the Phyletic Background of Genetic Psychology. The American Journal of Psychology, April, 1908, Vol. XIX, pp. 149-212.

*Jordar axi Kellogg. Evolution and Animal Life. New York, 1907. 489 pages.

A well-illustrated elementary discussion of facts, processes, laws, and theories relating to the life and evolution of animals. An excellent introduction to the subject.

Kedxe, Augustus II. Man, Past and Present. Cambridge, 1899. $58+$ pages.

Discusses the origins of the human race in general and its subdivisions.

Kedxe, Acgestes II. The World's Peoples. G. P. Putnam's Sons. London, 1908. 434 pages.

A popular account of the bodily and mental characteristics, beliefs, traditions, and political and social institutions of man. 270 illustrations.

Kelles, Helex. The World I live in. The Century Company. New York, 1909. 195 pages.

$A$ beautifully written book, full of hints on the psychology of perception.

Kinkpatrick, EDwix A. Genetic Psychology: An introduction to an objective and genetic view of intelligence. The Macmillan Company. New York, 1909. 373 pages.

MacDovgali, Robert. The Significance of the Hand in the Evolution of Mind. American Journal of Psychology, Vol. XVI, Pp. 232-24:3.

McDovgall, Willid. An Introduction to Social Psychology. John W. Luce and Company. Boston, 1909. 355 pages.

A good and somewhat new discussion of human instincts and their relation to social conduct.

*Maxgold, George B. Child Problems. The Macmillan Company. New York, 1910. 381 pages.

Gives a general view of the principal child problems of to-day.

Morgax, C. Lloyd. An Introduction to Comparative Psychology: London, 1900. 382 pages.

'This book and another, "Animal Behaviour," by the same author, though they deal with the subjects of instinct and intelligence in the lower animals, are full of concrete psychology suggestive to teachers. 
Rominson, Louis. Wild Traits in Tame Animals. Blackwood. London, 1897. 329 pages.

This is a charming book, full of interesting animal and genetic psychology. An informal but effective discussion of evolutionary themes.

*Ruediger, Willian Cari. The Principles of Education. Houghton Mifflin Company. Boston, 1910. 305 pages.

Brings together and organizes leading tendencies in modern educational thought pertaining to the bases, aims, values, and essential content of education.

* Suitil, Tileodate: L. Obstinacy and Obedience: A study in the psychology and pedagogy of the will. Pelagogical Seminary, March, 1905, Vol. XII, pp. 27-54.

*Thorndik, Ebward Ler. The Elements of Psychology. A. G. Seiler. New York, 1905. 351 pages.

Contains a very clear, concise description of the nervous system.

*Tylek, Joln Mason. Growth and Education. Houghton Mifflin Company. Boston, 1907. 291 pages.

Probably the best little single volume on the biological and physiological basis of education. Bibliography unusually good.

Wilder, Harisis II. History of the Human Body. II. Ilolt and Company. New York, 1909. 573 pages.

A very valuable illustrated account of the genesis of the luman skeleton, muscular system, nervous system, etc. in terms of embryology and comparative anatomy.

Witmer, Ligutwer. A Monkey with a Mind. The Psychological Clinic, December, 1909, pp. 179-206.

\section{PAR'T THREE}

*Bryant, Sara Cone. How to tell Stories to Children. Houghton Mifflin Company. Boston, 1905. 260 pages.

Dopp, Katnerine F. The Place of Industries in Elementary Edueation. Chicago, 1903. 280 pages.

Shows some of the relations between clild handwork and primitive industries. 
*Gulick, Luther H. The Healthful Art of Dancing. Doubleday, Page and Company. New York, 1910. 271 pages.

This book discusses the psychology and hygiene of dancing. Deals with the folk dance especially. The appendix has a useful list of practical references.

*Hale, G. Stanley (and Some of his Pupils). Aspects of Child Life. Ginn and Company. Boston, 1907. 326 pages.

Subjects treated : contents of children's minds, day dreams, curiosity, dolls, collecting, ownership, fetichism, boy life forty years ago.

Hall, G. Stanley. Youth, its Education, Regimen and Hygiene. D. Appleton and Company. New York, 1908. 379 pages.

Selections from the larger two-volume work "Adolescence." Treats handwork, play, and the period of preadolescence.

Hodge, Clifton F. Nature Study and Life. Ginn and Company. Boston.

Describes the life stories of plants and animals and relates these stories to the life of man.

*IIver, Edward B. The Psychology and Pedagogy of Reading. The Macmillan Company. New York, 1908. 469 pages.

Includes a review of the history of reading and writing and of methods, texts, and hygiene in reading.

*Johnson, Grorge Ellswortil. Education by Plays and Games. Ginn and Company. Boston, 1907. 234 pages.

An extremely practical book, describing hundreds of plays and games and grading them with reference to periods of development in childhood.

Lenkexs, H. T. Children's Drawings in Early Years. Pedagogical Seminary, 1896, pp. 79-110.

MacClintock, Porter Laxder. Literature in the Elementary School. The University of Chicago Press. Chicago, 1907. 305 pages.

This book discusses various types of clildren's literature and appends a course in literature for the elementary school.

Scott, Colis A. Social Education. Ginn and Company. Boston, 1908. 300 pages.

Deals with self-organized and other group activity in the elementary school. 
Sylvester, C. H. Journeys through Bookland. Ten volumes, with a manual for teachers. Bellows and Reeve. Chicago.

This is an attractive, well edited, graded collection of literature for children. Mother Goose and humor are well represented.

*Tanner, Amy Eliza. The Child: His Thinking, Feeling and Doing. Rand, McNally and Company. New York, 1904. 430 pages.

A good summary of the important topics in child study, including chapters on imagination, interests, emotions, imitation, language, music, drawing, play. List of references after each chapter.

The following periodicals contain scattered articles on the various subjects of the primary-school curriculum :

The Elementary School Teacher. Published monthly by The University of Chicago.

The Psychological Clinic. Published by Lightner Witmer, Philadelphia, Pennsylvania.

This is a useful, nontechnical illustrated magazine, devoted particularly to the training of the special child.

The Teachers College Record. Published monthly at Columbia University, New York.

The Training School. Published monthly by the New Jersey Training School for Feeble-ıninded Girls and Boys, Vineland, New Jersey.

A practical little magazine, especially valuable for teachers of special classes in public schools. It frequently describes concrete, individual cases.

\section{PART FOUR}

Addans, Jank. The Spirit of Youth and the City Streets. New York, 1909. 162 pages.

Allex, William H. Civies and Health. Ginn and Company. Boston, 1909. 411 pages.

Deals with the social sides of the health question, with special reference to the health of children. Good reading for those interested in initiating medical inspection. Contains many illustrations.

*Ayres, Leonard P. Open-Air Schools. New York, 1910. 171 pages. A practical illustrated volume.

*Burnham, William H. Articles on the Hygiene of the Nose, Teeth, Home Study, Spelling, etc. Pedagogical Seminary, Worcester, Vols. XII-XVII. 
Burnhay, William H. The Hygiene of Physical Education. American Physical Education Review, Springfield, Mass., Vol. XIV. [Reprint 30 cents.]

Clovstox, Thomas. S. The Hygiene of Mind. New York, 1907. 284 pages.

Colvis, Stephex. The Educational Value of Humor. Pedagogical Seminary, December, 1907, p. 517 .

Cramptox, D. Ward. The Influence of Physiological Age on Scholarship. Psychological Clinic, June, 1907, Vol I, PP. 115-121.

Forki, Acriste. Hygiene of Nerves and Mind in Health and Disease (translated from the German by H. A. Aekins). G. P. Putnam's Sons. New York, 1907. 343 pages.

Gulick Axp Arres. Medical Inspection of Schools. New York, 1909.

Furnishes necessary information for teachers and school boards who wish to introduce medical inspection.

Kelysack, T. N. Medical Examination of Schools and Scholars. P. S. King and Son. London, 1910. 434 pages.

A valuable, unique volume presenting the experience and views of thirty-six contributors from several countries.

Kex, Ellex. 'The Century of the Child. G. P. I'utnam's Sons. 1909. 339 pages.

Treats of child labor, soul murder in the schools, the right of the child to choose his parents, the unborn race and woman's work. This book has had au enormous circulation, especially throughout the countries of Europe.

Kline, Lixus W. The Psychology of Humor. The A merican Journal of Psycholog!y, October 1907 , 1. 421.

*Misawa, TAnasi. Modern Educators and their Ideals. 1). Alpleton and Company. New York, 1909. 304 pages.

An excellent summary of the educational views of great modem philosophers and reformers, including Pestalozzi, Froebel, W. T. Harris, and G. Stanley Hall.

Swift, Emgar James. Mind in the Making. Charles Scribner's Sons. New York, 1908. 329 pages.

A plea for the personal element in teaching, as opposed to " school-mastering education." Discusses nervous disturbances of development. 



\section{APPENDIX}

\section{THE MONTESSORI KINDERGAR'TEN}

\section{Note Axd References}

We add this appendix with some hesitation. After our book was ready for the press we became interested in the accounts of Dr. Maria Montessori's work and the American reception of her much-heralded methods. There is the usual danger that such methods, because they have taken a concrete form in merchantable apparatus, will be taken over in an ill-considered and halfconsidered manner.

While the Montessori Kindergarten, with its social features and its modern expressions of Froebel's philosophy and of Séguin's pedagogy, must surely have something to teach us, a precipitous adoption of the didactic apparatus all out of its natural setting and needed support will have possibilities of harm as well as of good. The Montessori ideas should at least go through a period of slow, adaptive naturalization, instead of being welcomed with an emotional readiness that promises to make Montessorianism a new cult.

We have attempted a preliminary critique of the pedagogical aspects of the Montessori Kindergarten, calling attention only to its serious sociological implications. We have gone as close to the original sources as the cireumstances permitted, and give below the references consulted.

Montrosori, Maria. Il metodo della pedagogia scientifica, applicato all educazione infantile nelle case dei bambini. Castello, S. Lapi ; Rome, M. Bretschneider, 1909.

"Montessori's Rediscovery of the Ten Fingers," Current Literature, October, 1911. 
May, Maude G. "The Montessori Method," The London Journal of Education, September, 1909.

REEDER, R. R. "The Montessori Method of Educating Children," Survey, January 20, 1912.

Smiti, Theodate L. "Dr. Maria Montessori and her Houses of Childhood," Pedagogical Seminary, December, 1911.

Stevens, Ellen Y. "Montessori and Froebel-A Comparison," The Elementary School Teacher, February, 1912.

'Tozier, Josephine. "Maria Montessori's Methods," McClure's Magazine, May, 1911; "The Montessori Schools in Rome," McClure's Magazine, December, 1911 ; "The Montessori Apparatus," McClure's Magazine, January, 1912.

\section{History of the Montessori System}

The historical origins of the Montessori Kindergarten are interesting and help us to understand its meaning. In 19061908 a real-estate society, l'Istituto di Beni Stabili, interested in the social betterment of the poor population of Rome, established four home schools, or nursery kindergartens, in connection with a group of tenement houses under the management of the society. Maria Montessori, M. D., was chosen to direct these now famous Case dei Bambini, or Houses of Childhood. Here she found ideal opportunities to conduct her original experiments and to develop her system of autoeducation.

The control of these tenement kindergartens logically fell to Madame Montessori, who was both a dottoressa and a professoress $a$, being the first woman to receive a medical degree from the University of Rome and later a lecturer on the education of the feeble-minded at Turin and at Rome. She has also been assistant of the Psychiatrical Clinic at the University of Rome, Director of the Scuola Magistrale Ortofrenica (for subnormal children), and a student of anthropological pedagogy and experimental psychology. In addition to her scientific perception of education, Dr. Montessori has a warm interest in social problems, and her work must be regarded from the social as well as from the pedagogical standpoint. 
The "Montessori Method" has been adopted in two schools in Milan and in the Asili d'Infanzia of Italian Switzerland, where it is reported to be displacing the Froebelian system which formerly held sway.

So we have here to reckon with a new kindergarten, which may come in conflict with the old. In what sense is it new?

Over a hundred years ago lived the great educator who, also, had an Italian name, Pestalozzi, and who, also, was concerned with the problem of the home. For over half a century he labored to simplify, to mechanize, to psychologize education, and sought "to render the ordinary means of instruction so simple as to permit of their being employed in every family." The same mechanistic tendencies are present in Montessori's autoeducation system, but in the presence of the tall tenements of the Italian ghetto she has reversed Pestalozzi's dream. "Let us," she says, "place the school in the home; not only that, but let us place it there as a collective property, and let us place under the eyes of parents the entire life of the teacher, in the accomplishment of her high mission" (Il metodo della pedagogia scientifica, p. 45). This is the social pedagogy of Montessori, "which solves the social and pedagogical problems which seemed impossible, and takes part in the modern transformation of the home." Just as we have socialized dwellings, water supply, laundry, medicine, etc., so we must "socialize the maternal function" through the kindergarten, as a school in direct physical comnection with the home. We make a mistake when we identify the name of Montessori with didactic apparatus only. She is to publish a volume on the Casa dei Bambini come Scuola in Casa, "The House of Childhood as a School in the Home." Her original kindergartens at Rome are literally nursery schools in the home.

Froebel was the founder of the modern kindergarten, of both its nursery and its pedagogical features. We find in his writings and methods the equivalent of many of Dr. Montessori's ideas. Much of the rhythm, game, and occupation activities of the houses of childhood are found in the Froebelian 
gardens of childhood, and even the didactic sense material of Montessori has something in common with Froebel's graduated gifts. Dr. Montessori's makes it clear, however, that she does not approve a wooden use of such material, and that she would impose no arbitrary sequence of tasks or plays from without. She and Froebel alike emphasize the immortal principle of selfactivity. Dr. Montessori calls it the principle of autoeducation, and has invented for its expression, not ten gifts, but an elaborate system of some eleven hundred pieces of autosensorial didactic apparatus.

Not from Froebel, but from Itard and Séguin, did Dr. Montessori gain her inspiration for the methods of autosensorial education. She regards her work as the continuation of the efforts of these two French physicians - " my illustrious predecessors" - and is generous in the recognition of their suggestive endeavors in the education of defectives. In $1801 \mathrm{Dr}$. Itard published his account of "The Education of a Human Savage," the savage of Aveyron, the idiot child whom hunters had found roaming wild in the woods. In $1864 \mathrm{Dr}$. E. Séguin published his classic treatise on "Idiocy, its Diagnosis and 'Treatment by the Physiological Method." Séguin for the first time elearly demonstrated the organic relation between sensory and intellectual development, emphasizing the peculiar importance of touch and stereognosis. He introduced into the training of the feeble-minded the use of geometric insets and other graduated sense material. Dr. Montessori has elaborated and extended these methods to the education of normal children. Her experience was first with the subnormal, and her conceptions of education bear the stamp of medicine and physiology, and of experimental rather than genetic psychology.

\section{The Didactic Nurserx}

The original Montessori Casa dei Bambini may be best characterized as a nursery-kindergarten-school in the home, "where children from four to five years old read, write, and do number 
work with a facility equal to that of children of the second and third grades." How completely the maternal function is socialized in such a pedagogical nursery is well shown in the following regulations, to which the parents must prescribe.

"The parents of children attending the Cusa dei Bumbini pay no contribution whatever, but they assume these imperative obligations: (A) To send their children to the schoolroom at a specified hour, clean in person and clothing, and with a suitable pinafore. (B) To show the greatest respect and deference toward the directress and all other persons connected with the Casa dei Bumbini, and to coöperate with the directress in the work of educating their children. At least once a week mothers will be able to speak with the directress, reporting observations on their own children in their home life, and receiving from the directress notes and suggestions for the welfare of the children.

"There will be expelled from the Casa dei Bambini (a) those who present themselves in an un washed and slovenly condition, (b) those who show themselves not amenable to discipline, and (c) those whose parents fail in respect to those placed in charge of the Casa dei Bambini, or in any way threaten to destroy by bad conduct the educational work which is the aim of the institution.

"Attention must be paid to the health and physical and moral development of the children by means of lessons and exercises adapted to their age.

"There will be in charge of each Casa dei Bambini a directress, a physician, and a caretaker. All children in the block between the ages of three and seven years have the right of admission to the Casa dei Bumbini."

The charming pictures of the Casa dei Bambini at Rome show us no ill-lighted schoolroom, with rows of desks, "designed to permit the greatest immobility," screwed down to the floor. We see happy children moving freely through the large, unconfined spaces of garden and open-air corridors. They are playing on the floor or working at movable tables, eating 
soup at a luncheon in the courtyard, or singing an Ave Maria in the hall of a roomy cloister. And in the background are the figures of skillful women, - physician, directress, caretaker, and nuns, - who are guiding this happy, spontaneous life. The pictures are full of refreshing suggestions of health and freedom.

The central principle of the Montessori education is the widely accepted one that children should develop freely through their own spontaneous energies and interests. Ir. Montessori's distinction lies in the fact that she has bravely put this principle into effect, and guarded, at the same time, the physical development of the children. "The children are left free to play when they will and they may sleep when they will."

Dr. T. L. Smith, who spent a day at one of the schools, says : "If one visits one of Dr. Montessori's schools, the children all seem to be occupied in interesting play. Some are lying on the floor playing with blocks or strips of wood painted in different colors. Some are playing blindfold games, finding out by the aid of their fingers alone the shapes and sizes of objects and different textures of silk, satin, wool, or linen.... But the interest and attention of the children is never interfered with. If a child wishes to spend the entire school period of two hours in doing one thing, he is allowed to do so, on the principle that the spontaneous attention is a fundamental educative principle which must not be interfered with."

Another visitor, Miss Maude G. May, testifies likewise: "No one who has visited any of the Case dei Bambini can fail to have been struck by the intelligence of the children, by their frank, simple manners, neither forward nor shy, by the atmosphere of happy activity, and by the sense of discipline that is largely voluntary and rises out of this same activity:"

The unthinking person alone will ascribe these excellent results to the cunningly contrived didactive apparatus, which may be bought over a counter. It must be remembered that the Montessori Casa is a school in the home, that the parent patrons are under important contract regulations, and that the 
children are under continuous skilled supervision for many hours. In the convent on the Via Giusti they are detained from nine until half past five, that is, eight hours and a half, and only one fourth of this time is given to school work. Dr. Montessori recommends that in summer the hours extend from eight until six, with poor children. She favors these long hours because they permit the serving of luncheons to and by the children, the rest and play periods, and the attention to the physical needs of the pupils, - all of which together make the brief lesson periods apparently so productive of educational results. A day's program includes "the exercises of practical life," like dressing and undressing (putting on the clean pinafore); washing (the children wash themselves); dusting, etc.; inspection of teeth, nails, neck, ears, face, shoes, clothing ; light gymnastic exercises; singing, dancing, and rhythm work; instruction in walking, sitting, moving carefully about the furniture, climbing the stairs, etc.; speech exercises; luncheon, when the children serve the soup, carry bowls, wait at table, and wipe dishes; playing in garden; sleeping.

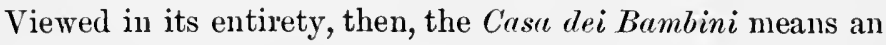
eight-hour day for the children, under the socialized maternal control of professionally trained women, with physician and caretakers assisting. Reading and writing are, after all, an unimportant feature of this eight-hour program, when compared with the hygienic and sociological features which seem to excite little attention. When we consider the Italian results and the American possibilities of the Montessori method, we must not attribute to the didactic material the large moral and motor results which grow out of a free, hygienic enviromment and the power of superior personalities.

The moment that one reduces any philosophy of education to concrete, graduated material, it loses the unity and vital impulse which created it, and invites as many interpretations as there are individuals to handle it. The Montessori system is an eight-hour nursery-kindergarten-school, and not a set of purchasable didactic apparatus. 


\section{The Writing and Reading Method}

Teaching the kindergarten children to write has been called "the most striking and impressive of Montessori's achievements." The accounts of this particular achievement stir the imagination. We read of "the explosion into writing," the dramatic discovery of the method, "the frenzy of writing which attacked and spread through the whole group of children." Nearly all the pupils learn penmanship at four, and usually it takes only a month or six weeks before they "burst forth into writing."

Unthinking people seize upon this achievement as the most important contribution of the Montessori education. It has been overadvertised and so "overheralded" that we are left with the impression that American children can learn to write with ease and economy only by the Montessori devices. Does this necessarily follow?

In the first place, Montessori makes penmanship a kindergarten occupation. A few years ago we were advised, on hygienic grounds, that children should not be taught reading and writing until the age of ten; now they are to be inducted into writing at the kindergarten age of four, though the period of muscular nascency may extend to the age of seven. Dr. Montessori herself is coming to the conviction "that it is not natural for children under six, unless they are overstimulated, either to read or write continuously." This means that the hygienic and economic reasons for teaching reading and writing two or three years before they can be jointly used with a motive in the natural communication and interpretation of thought remain to be established.

There seems to be nothing new in the Montessori method of teaching reading. The intelligent primary teacher has been using games, cards, and action phrases for many years. In fact, the teaching of reading is not such a serious matter, and many children in America effloresce spontaneously into the power to read. However, it is still a question when the technique shall 
be taught. Shall we hurry it into the kindergarten period or shall we wait until the child's interests and activities are ripe for such expression? Children can learn to read at three or at six. In the former case reading is merely a technical feat; in the latter it is a complement of the child's more mature intellectual capacity.

The Montessori method of teaching penmanship presupposes a preliminary course in sense training. The method is clearly an annex to the system of sensorial education, and does not represent the more naturalistic, genetic approach to the writing problem. It has the merits of admitting play and independent effort, but it is in spirit alphabetic and logical rather than genetic.

The sequence of exercises which lead to writing is as follows : 1. Tactile discrimination of surfaces, rough, smooth, ete. 2. Discrimination of weights. 3. Tactile exploration of outlines of geometric forms, square, circle, etc. 4. Filling in of geometric designs limited by a frame. 5. Filling in of same limited by peneil marks. 6. Sandpaper alphabet over which the pupil moves his forefinger, associating the phonetic value of the letter with the movement.

According to this sequence, writing does not make organic connection with the child's instincts of drawing, imitation, and language. The writing becomes a technique-game, and the emery-paper letters are pedagogical toys. The more purely genetic procedure in learning to write places more reliance on spontaneous drawing as a means of learning to control both the writing instrument and the basal movements. The value of such spontaneous drawing seems to have little recognition in the Montessori system. Dr. Montessori substitutes the rather artificial exercise of filling in geometric designs.

The same sudden bursts into spontaneous writing shown by Italian children cannot be expected in America, since our language is not phonetic. Even some of the Italian children do not manifest this sudden burst into writing, and need the assistance of the teacher ( $I l$ metodo, etc., p. 236). American 
children would have special difficulties, because writing technique and spelling are unfortunately two very distinct things, whereas in Italy one is equivalent to the other, and calligraphy is orthography. To construct a simple illustration, an American child and an Italian child wish to write the sentence, "I would like to buy my rye bread to-night." The Montessori pupil, having learned his letters, simply has to think the sound of the sentence, and it writes itself. This is the spontaneous burst into writing. In his vernacular he spells Io vorrei comprare stasera il mio pane di segale. The American child, on the contrary, even though he has learned his letters and can recognize them blindfold, would meet difficulties which might delay the explosion, as $u l$ in would, the $e$ in like, the $u$ in buy, the $e$ in rye, the $a$ in bread, and the $g h$ in night. The phonograms ike and ight, to be sure, may be tauglit by the sandpaper, but this destroys the simplicity of the method, and after all there is no need of teaching the American primary child as though he were blind; the visual image of the whole word is so much more natural. The word method of teaching writing is quite feasible, and when it is preceded by drawing and rhythmic picture writing, the acquisition of penmanship in our country may be a hygienic, joyous task.

The muscles are the machinery by which man projects his ideas, and their training should from the beginning be the result of the execution of ideas. For instance, to write, a child must learn to control his pencil. How shall he do it? Not by setting mechanical limitations for himself, as the filling in of outlines of various geometric forms, but by utilizing, in bold freehand drawing, his instinctive and creative desire for representation,- by projecting on the blackboard a representation of rhythmic ideas which direct and inhibit muscular action in the very process of representation; in other words, he should achieve muscular control by the expression of native ideas rather than by fixing limitations from without. 


\section{The Sensorial Apparatus}

The autosensorial scheme of education bears the marks of its origin, that is, the laboratory material for the experimental psychology of the senses and the methods used in training the perception of defectives, - the blind, deaf, dumb, and feebleminded. It comprises an impressive array of sense material designed to bring into the consciousness of childhood, not things, but the qualities of things, that is, hundreds of graduated colors, sounds, sizes, shapes, lengths, widths, temperatures, etc. It is not a scheme of object teaching; the separate qualities of objects are didactically isolated from the objects, for technical discrimination and attention. This method has worked in the training of sense defectives.

A word of caution is in order with respect to the general tendency to take over, without criticism, the findings from experience with subnormal children, and to transfer them to the normal child. Especially is this true of the learning process, where it would be much safer to get our suggestions for the education of normal children from the learning processes of genius, or of the supernormal, for normal children tend to learn like geniuses rather than like idiots. They divine truth; they make short cuts; they work with wholes and as whole beings, not with isolated aspects ; they imbibe and assimilate; their reactions to nature are not analytic-synthetic.

The fact that methods of sensorial training have proved useful with sense defectives and those mentally deficient must therefore be used with due caution. In our country a well-considered system of sensorial education has been in use and development for some twenty years in The Massachusetts State School for the Feeble-Minded, where the great Séguin himself taught for a short time. Dr. Walter E. Fernald, superintendent of this institution, has been especially successful in the training of the lower grades of feeble-mindedness. He emphasizes that success depends upon carefully following a progressive, predetermined sequence, beginning with the simplest exercises, such as picking paper from 
the floor. While the sense material is simple, it is very important that the training be conducted "in the most painstaking, conscientious, and thorough manner by a teacher" who has herself been trained in the method and meaning of the work.

The principle underlying the work, especially as applied to the training of the feeble-minded, is stated by Dr. Fernald as follows: "The physiological exercise and education of the special senses, and the training of the voluntary muscles to directed accurate response, must precede and prepare the way for so-called intellectual training. The intelligent use of the special senses is the basis of all knowledge. The inactive special senses, the obstructed avenues of approach to the central intelligence, must be opened up by a series of carefully arranged sensorial gymnastics."

That feeble minds are ever made normal or nearly nor'mal by such methods is a sheer impossibility. While admitting that normal children have "a sense hunger" which the average schoolroom poorly meets, it may well be questioned whether we should therefore resort, in our common schools, to a refinement of the sense material and the didactic methods employed with the feeble-minded. Dr. Fernald himself recognizes that in normal infancy and childhood "the extraordinary activity of the special senses, and an innate spontaneity of action, enable the child to rapidly acquire a wide experience. His acute powers of attention, observation, and perception, impelling him to closest scrutiny and investigation of each new thing, and his countless experiments in physics, all of which we call play, are the means adopted by nature to exercise and develop the faculties. . . . This control of the body and its functions, and familiarity with the simple properties of matter and force, which a normal child seems to acquire almost intuitively, can be gained by these (feeble-minded) children only after a longcontinued process of training."

'There is one fallacy about this matter which deserves clearer' recognition. Many of the possible results from "sense training" are not due at all to the development of sense susceptibility or sensory capacity. The beneficial part of the training is 
motor, due to the motor adaptations of attention, observation, discrimination, and delicate handling. This so-called sense training is valuable for the feelle-minded, not because it is sense training, but because it is motor training. The sense material conveniently furnishes the simple, isolated stimuli to which the feeble mind may be made to attend, but the attention is primarily a motor process of handling, touching, listening, lifting, pressing, coördinating eye movements and hand movements, etc. Even in tasting and smelling, muscles play a part. Perception is not a receptive but an active motor process; the motor neurons, or at least efferent impulses, are always involved.

It is the motor element of response to simple serial situations which makes "sensorial" training beneficial to inferior minds, but with normal children these organizing, educative motor reactions grow out of natural contact with real objects, and this motor response is best furthered, not by imposing external restrictions in directive sensorial stimuli, but by making use of the internal motives which grow out of natural curiosity and workmanship, the instincts of play and work. Instead of taking recourse to didactic sensorial apparatus, let us, even in the tenement districts, hold to our faith in nature, elementary science, and handwork.

One of the threatening evils of education is oversophistication. It is so easy to philosophize and to become mysteriously didactic, to surround the everyday natural interests and characteristics of childhood with impenetrable psychological analysis. The great teachers of the world are those who have met youth and childhood in simple, natural, personal contact,_- who have brought education into naïve relations with nature. Our school system does not need devices, technical apparatus, graduated and systematized processes. No such order and progression exist in the child's learning process. He is equipped with delicate perception and endowed with instinctive self-activity which enables him to discover and assimilate a multitude of tactile, motor, and visual impressions in the daily round of his natural experiences. 
It is disastrous to admit that it is impossible for babies of two, three, and four to find a stimulating environment in the home, and that the mothers of the country shall transfer to the schools the function of educating these little children in sense perception. The majority of children find ample opportunity in their daily domestic excursions to handle various forms, to touch hard, soft, smooth, elastic surfaces. The baby crawling on the floor begins to run his fingers over the carpet, the furniture, the windowpane, the soft dress his mother wears, her hair, etc. He plays by the hour with this thing and that, unconsciously assimilating, sifting, enjoying, and comparing a multitude of impressions, very many of which cannot be incorporated even into the most elaborate sensorial apparatus. Why take such natural experience and reduce it to a series of graduated, self-conscious impressions, bringing into the classroom a lot of unnecessary paraphernalia? The modern kindergartners find themselves hampered by similar static material, and many of them are discarding it for more easy, natural contact with useful, commonplace material. It is again the question of the logical versus the genetic order in education. We have, after a long struggle, dragged the schoolmaster's mind away from the logical, alphabetic, serial method of educating little children. Kindergarten and primary school alike need practical contact with life, science, and manual work. We must make use of the bountiful experiences and phenomena of everyday life and not construct an artificial series of boxed experiences increasing in refinement and making no useful whole, - no familiar object about which the child should be informed.

It cannot very well be argued that such sense training is to be only supplementary to natural contact with life, for, in America at least, the danger is that it will become a substitute, not a supplement. In the Italian Casa dei Bambini the children spend an eight-hour day.

Nor can it be argued with conclusiveness that this special sense training will increase the general susceptibility 
and keemness of the child's perception of nature. In fact, the experimental studies on this very point (by Thorndike and Woodworth) in American laboratories show that there is no "mysterious transfer of practice," - that the influence of improvement in one mental function upon the efficiency of other functions is very small; for instance, training in the estimation of magnitudes and weights had little influence on the ability in the estination of magnitudes and weights of the same general sort.

Moreover, the moment that one insists upon elaborate didactic material, the natural relation of the child to life is in danger. Especially in the hands of inexperienced teachers this graduated sense training will become sophisticated, both for the teacher and for the child, and will inject an analytical, sophisticated self-consciousness into his otherwise naïve relations to the colors and shapes of nature, - to the rainbow, to crystals, and to the spectral hues on his soap bubble.

These strictures do not apply with equal force to the arithmetical didactic material, for here emotion and the natural unity of things do not count for so much, and quantitative analytic attitudes are appropriate. The Montessori arithmetical apparatus has many excellent uses.

But in other departments of life it is the appreciation of things which counts, and not the knowledge of their abstract qualities. Assimilation must take place as an accompaniment of a psychic experience. The child develops in the afterglow of feeling and understanding which follow contact with real objects in their natural relation to life. A knowledge of the chromatic musical scale, or a quick recognition of shades and tints, is not the starting point of artistic creation, but a final result of the needs of execution.

There is no doubt that one can teach a little child almost anything, but he is standing on the threshold of life. Life calls to him to come to investigate, to inquire, to live. Let us, then, open the way for an easy, natural contact with live things, and not use up his vibrant energy upon artificial experiences. 


\section{The Teacher's Pakt}

There is, at the present writing, only one person in this country who has been trained by Dr. Montessori in the practice and principles of her method. In spite of this, factory machinery is being set up for the wholesale production of her didactic materials. This raises some questions about the relation of the teacher to the material and the method. When the Montessori system was first commercially introduced to the American public, we were told that any parent or teacher who had a little leisure to read the accompanying handbook might place the didactic apparatus in the hands of the children, who wonld play themselves into knowledge.

Dr. Montessori has been called an educational wonder-worker, but it is safe to say that the magic power does not reside in the didactic material. Her philosophy is the liberty of self-activity in the pupils; her method, that of "autosensorial education." It is autoeducation, but it is not automatic. If it succeeds, it will succeed only in the hands of the most skillful and understanding teachers. Dr. Theodate L. Smith, who saw the schools at Rome, declares, "There is no system that requires a more careful training of its teachers."

Dr. Montessori herself leaves no doubt on this matter, in her chapter, "How the Teacher should Teach" (Il metodo, etc., pp. 79-87). It is her wish that "the educator should be imbued with a profound worship of life," and should regard the child as a growing organism. The teacher must have a perception for nascent stages and, while respecting the individuality of the child, must direct his development, as one trains the vine, without pruning or thwarting it. In fact, Dr. Montessori has chosen the word " directress " to replace the word " teacher," which implies too much instructing intervention. The directress, then, must restrain all corrective and "teachy" measures, in order quietly and tactfully to direct. Such directing requires not only scientific curiosity and sagacity but scientific patience. 
A class of about twenty-five can be directed by one Montessori teacher and an assistant. Larger numbers make the principle of self-activity difficult of application. This has proved so true of our large American - and Italian - kindergartens, that Miss Stevens, writing from Rome, makes this contrast between "Froebel's" system and Montessori's: "Froebel's teachers are in front of their children, leading them, directing them; Montessori's are behind theirs, watching them, quietly removing all obstacles to their development, silently placing within their reach all helps to their progress, but leaving the initiative entirely to the children."

In the Montessori kindergarten it therefore sometimes happens that no two children are engaged in the same occupation. It may also happen that a child will spend the whole two hours of the school period in doing one thing, for Dr. Montessori wisely holds that a child should not be interrupted in wholesome activity. This, however, brings about a danger of overstimulation, and the directress must be not only an expert disciplinarian (in the best sense) but a discerning guardian of the hygienic requirements of the child's development. The teacher's part is to discern, to direct, to regulate.

This is a somewhat passive part, but it requires superior skill. Says Dr. Montessori: "When she [a prospective teacher] begins to find it her duty to discern which acts of the child she ought to hinder and which she ought to observe, then the teacher of the old school feels a great lack in herself, and begins to ask if she will not be quite inadequate to her task." "The fundamental guide in the lessons is the method of observation, which is included in the principle of child liberty." "Our intention is to give a ray of light and then pass on to something else." "In fact, when the child educates himself, and the control and correction of his errors is left to the teaching material, it remains to the teacher only to observe. She must be more of a psychologist than a teacher, and here is proved the importance of the scientific preparation of teachers." 
In the education of young children the teacher will always be of more importance than the method or the material. Miss Tozier describes the wonderful educational results achieved by Signora Galli-Succenti, a Montessori directress, in the worst slum of Rome, - results which in this case were proved to be independent of any didactic material, for the local school board was dilatory in providing the apparatus. "In teaching these children of St. Angelo in Pescheria, neither reading nor writing nor the use of the materials was the main aim or desire of Signora Galli and her assistant. Had these inferior ambitions been allowed to influence the work in the school, there would have been little accomplished in the long months of waiting for the didactic toys, - months that proved so valuable in the real education of the poor children."

Some of the finest things which we have found in Dr. Montessori's views are her ringing statements of the function of the teacher. She believes that "the figure of the old schoolmistress, who labors to preserve the discipline of immobility, and wears out her lungs in a shrill and continuous flow of talk," must disappear. She believes it to be nothing less than a sacred duty for the teacher to preserve only the discipline through liberty, - " the liberty of the child in his free, spontaneous manifestations." Her new emphasis of this old principle will be a service to the race.

But the fulfillment of this principle in our country needs skillful personalities more than it needs didactic apparatus. Apparatus without trained personality in "the directress" will be insidiously dangerous. 


\section{INDEX}

Adenoids, 278, 283

Adolescence, 310

Anweba, 31, 108

Aniunal intelligence, $50,55,62$, 88

Appreciation of things, 117

Aryan peoples, 58

Bibliography, 315

Busy-work, 229

Cerebral cortex, 37, 43, 107, 282

Child depravity, doctrine of, 3

Child-hygiene movement, 26

Clild study, history of, 21

Crying, 79

Daneing, 242

Darwin, 17, 22

Dementia proccox, 291

Dickens, 5

Discipline, 148, 248

Dramatic expression, 144

Drawing, 125

Epaminondas, 299

Evolution, 30

Eyes, 280

Feeble-mindedness, 290

Froebel, 21, 129

Habit, 50, 55, 74

Hall, G. Stanley, 20

Handwork, 181
Hearing, 116

Home education, 264

Humanitarianism, 3

Humor, 130, 254, 296

Idiot lıand, 99

Imitation, 72

Instinet, $55,60,61$

Keller, Helen, 113, 120

Language, 147, 172

Langhter, i1

Left-handedness, 92,97

Literature, 187

Logical versus genetic method, 128

Mesozoie period, $4 \bar{i}$

Mood, 208, 245, 292, 305, 308, 312

Morality, 252, 302, 309

Morning exercises, 243

Mother Goose, 189, 200, 212

Movement and intelligence, 88

Mutual aid, 69

Nail biting, 104

Nature study, 223

Neolithic man, $5 \pi$

Neurology, history of, 12,15

Neuromuseular system, 87

Neurons, 33, 40, 282

Obstinacy, 80

Open air, 285 
Paleolithic man, 54

Paleozoic period, 46

l'aper cutting, 139

Parental instincts, 67

Perception, 100, 117

P'estalozzi, 4, 118, 257

Peter, 50

Phonics, 159

Pithecanthropus erectus, 48

Play, 70, 158, 237, 312

Posture, 281

Puppet play, 155

Reading, 194

Reading to children, 201

Relaxation, $76,83,286$

Rhythm, 208, 212

Right-handedness, 65, 91, 95

Seeing, 116

Self-preservation, 64

Sex education, 227,314

Shaftesbury, 5

Sleep, 76
Smell, 115

Social instinets, 68

Speech, 96, 159

Speecl defects, 164

Spelling, 218, 232, 234

Story-telling, 138, 191

Study, 235

Taste, 115

Teeth, 273

'Tertiary period, 47,53

'Thumb, 94, 104

Touch, 100

Tropisms, 64

Verbalism, 119

Vesalius, 10

Walt Whitman, 123

Wild traits in tame animals, 63

Work, 81, 235, 312

Workınanship, 60, 73, 75, 182

Writing, 203 

me of hrshinet Physical activity UNIVERSITY OF CALIFORNIA LIBRARY, LOS ANGELES EDUCATION AND PSYCHOLOGY LIBRARY This book is DUE on the last date stamped below.

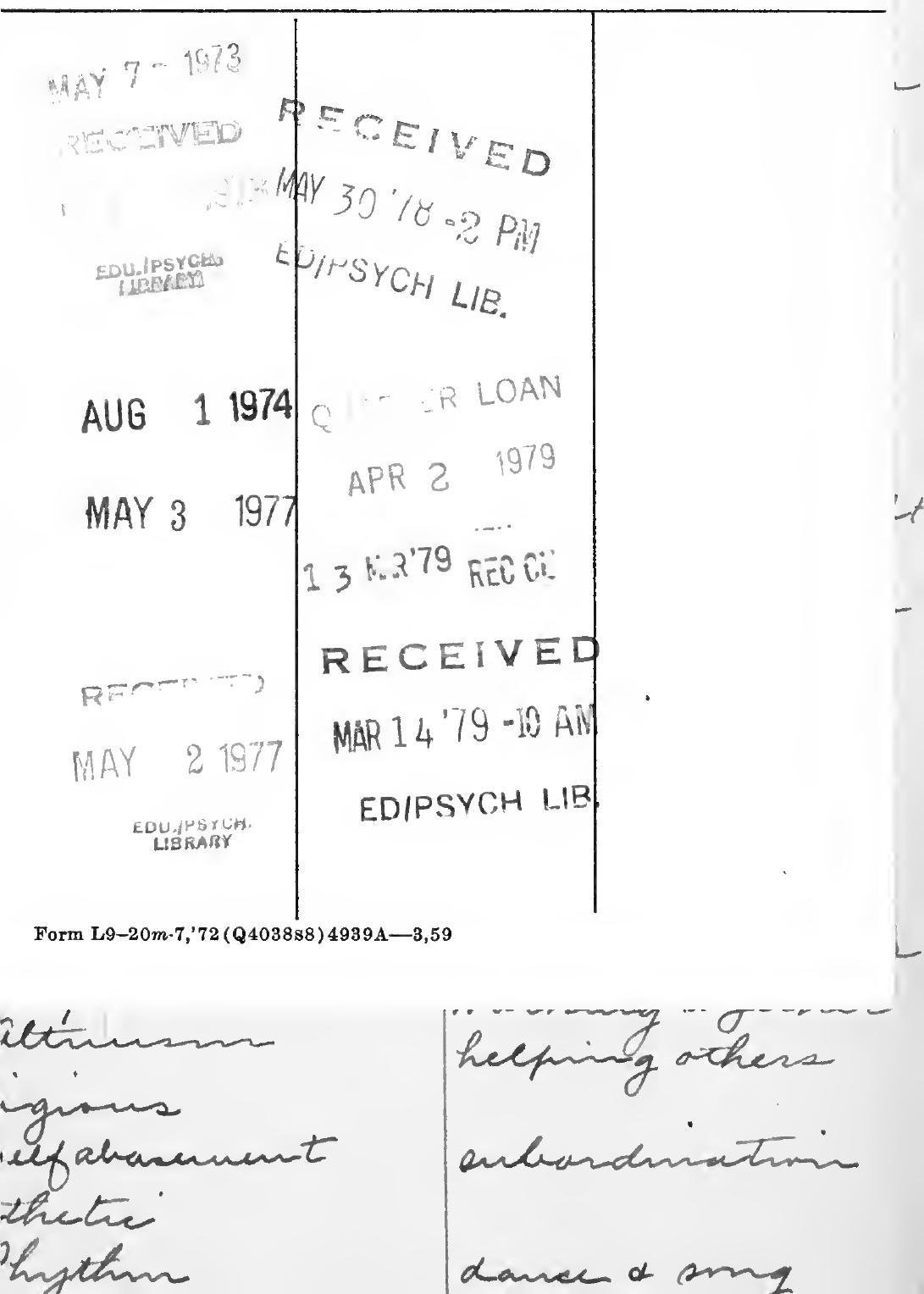




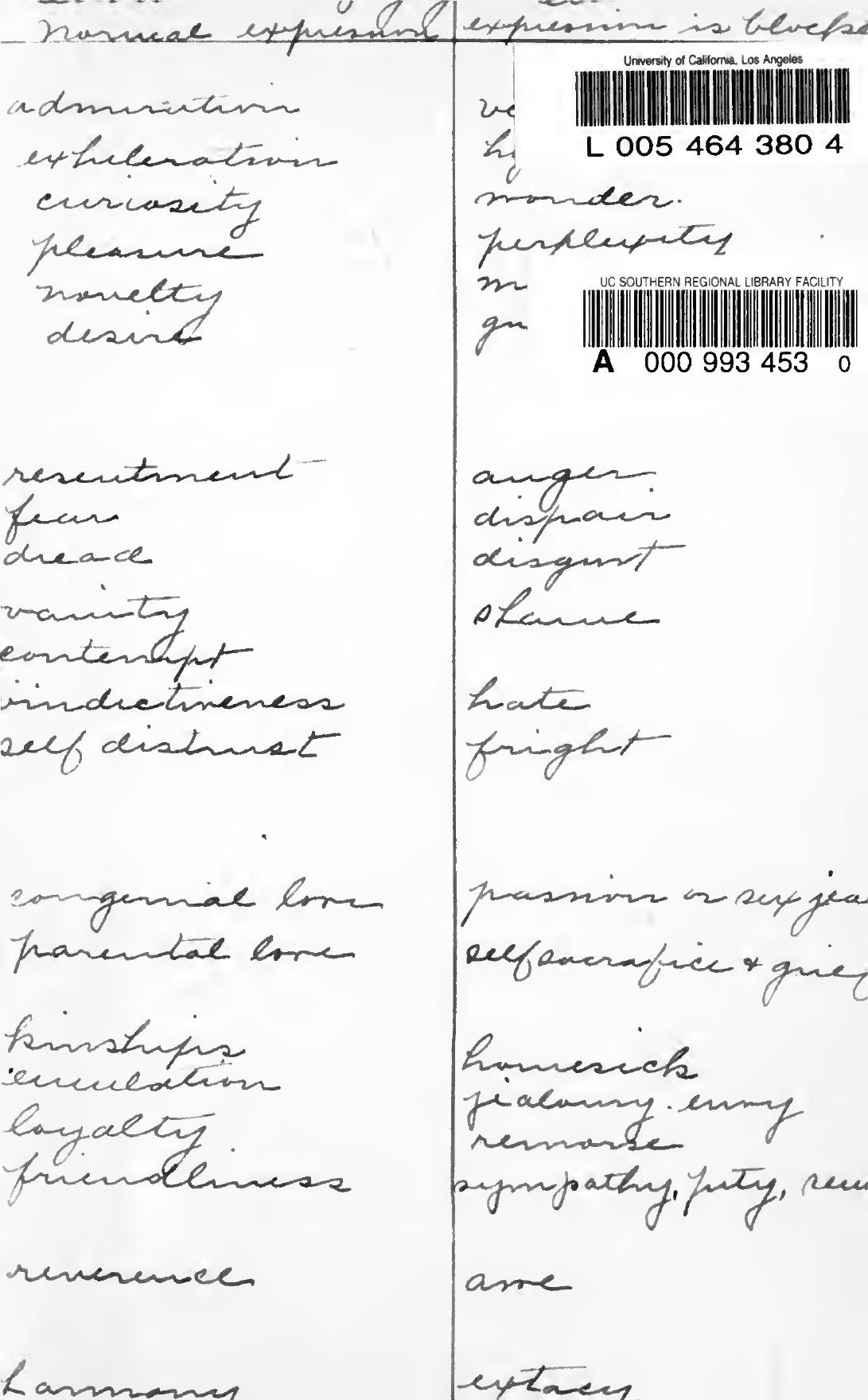


